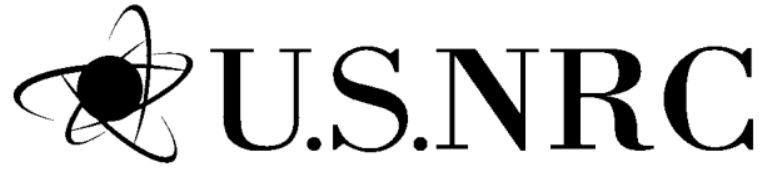

NUREG/CR-7013 ORNL/TM-2009/321

United States Nuclear Regulatory Commission

$\overline{\text { Protecting People and the Environment }}$

\title{
Analysis of Experimental Data for High-Burnup PWR Spent Fuel Isotopic Validation - Vandellós II Reactor
}




\section{AVAILABILITY OF REFERENCE MATERIALS IN NRC PUBLICATIONS}

\section{NRC Reference Material}

As of November 1999, you may electronically access NUREG-series publications and other NRC records at NRC's Public Electronic Reading Room at http://www.nrc.gov/reading-rm.html. Publicly released records include, to name a few, NUREG-series publications; Federal Register notices; applicant, licensee, and vendor documents and correspondence; NRC correspondence and internal memoranda; bulletins and information notices; inspection and investigative reports; licensee event reports; and Commission papers and their attachments.

NRC publications in the NUREG series, NRC regulations, and Title 10, Energy, in the Code of Federal Regulations may also be purchased from one of these two sources:

1. The Superintendent of Documents

U.S. Government Printing Office

P.O. Box SSOP

Washington, DC 20402-0001

Internet: bookstore.gpo.gov

Telephone: 202-512-1800

Fax: 202-512-2250

2. The National Technical Information Service

Springfield, VA 22161-0002

www.ntis.gov

1-800-553-6847 or, locally, 703-605-6000

A single copy of each NRC draft report for comment is available free, to the extent of supply, upon written request as follows:

Address: Office of the Chief Information Officer,

Reproduction and Distribution

Services Section

U.S. Nuclear Regulatory Commission

Washington, DC 20555-0001

E-mail: DISTRIBUTION@nrc.gov

Facsimile: 301-415-2289

Some publications in the NUREG series that are posted at NRC's Web site address

http://www.nrc.gov/reading-rm/doc-collections/nuregs are updated periodically and may differ from the last printed version. Although references to material found on a Web site bear the date the material was accessed, the material available on the date cited may

subsequently be removed from the site.

\section{Non-NRC Reference Material}

Documents available from public and special technical libraries include all open literature items, such as books, journal articles, and transactions, Federal Register notices, Federal and State legislation, and congressional reports. Such documents as theses, dissertations, foreign reports and translations, and non-NRC conference proceedings may be purchased from their sponsoring organization.

Copies of industry codes and standards used in a substantive manner in the NRC regulatory process are maintained at-

\section{The NRC Technical Library \\ Two White Flint North 11545 Rockville Pike Rockville, MD 20852-2738}

These standards are available in the library for reference use by the public. Codes and standards are usually copyrighted and may be purchased from the originating organization or, if they are American National Standards, from-

American National Standards Institute 11 West $42^{\text {nd }}$ Street New York, NY 10036-8002 www.ansi.org 212-642-4900

Legally binding regulatory requirements are stated only in laws; NRC regulations; licenses, including technical specifications; or orders, not in NUREGseries publications. The views expressed in contractor-prepared publications in this series are not necessarily those of the NRC.

The NUREG series comprises (1) technical and administrative reports and books prepared by the staff (NUREG/XXXX) or agency contractors (NUREG/CR-XXXX), (2) proceedings of conferences (NUREG/CP-XXXX), (3) reports resulting from international agreements (NUREG/IA-XXXX), (4) brochures (NUREG/BR$X X X X)$, and (5) compilations of legal decisions and orders of the Commission and Atomic and Safety Licensing Boards and of Directors' decisions under Section 2.206 of NRC's regulations (NUREG0750).

DISCLAIMER: This report was prepared as an account of work sponsored by an agency of the U.S. Government. Neither the U.S. Government nor any agency thereof, nor any employee, makes any warranty, expressed or implied, or assumes any legal liability or responsibility for any third party's use, or the results of such use, of any information, apparatus, product, or process disclosed in this publication, or represents that its use by such third party would not infringe privately owned rights. 
United States Nuclear Regulatory Commission

Protecting People and the Environment

\section{Analysis of Experimental Data for High-Burnup PWR Spent Fuel Isotopic Validation- Vandellós II Reactor}

Manuscript Completed: August 2010

Date Published: January 2011

Prepared by

G. Ilas and I.C. Gauld

Oak Ridge National Laboratory Managed by UT-Battelle, LLC

Oak Ridge, TN 37831-6170

M. Aissa, NRC Project Manager

NRC Job Code N6540 



\begin{abstract}
This report is one of the several recent NUREG/CR reports documenting benchmark-quality radiochemical assay data and the use of the data to validate computer code predictions of isotopic composition for spent nuclear fuel, to establish the uncertainty and bias associated with code predictions. The experimental data analyzed in the current report were acquired from a high-burnup fuel program coordinated by Spanish organizations. The measurements included extensive actinide and fission product data of importance to spent fuel safety applications, including burnup credit, decay heat, and radiation source terms. Six unique spent fuel samples from three uranium oxide fuel rods were analyzed. The fuel rods had a $4.5 \mathrm{wt} \%{ }^{235} \mathrm{U}$ initial enrichment and were irradiated in the Vandellós II pressurized water reactor operated in Spain. The burnups of the fuel samples range from 42 to $78 \mathrm{GWd} / \mathrm{MTU}$. The measurements were used to validate the two-dimensional depletion sequence TRITON in the SCALE computer code system.
\end{abstract}




\section{CONTENTS}

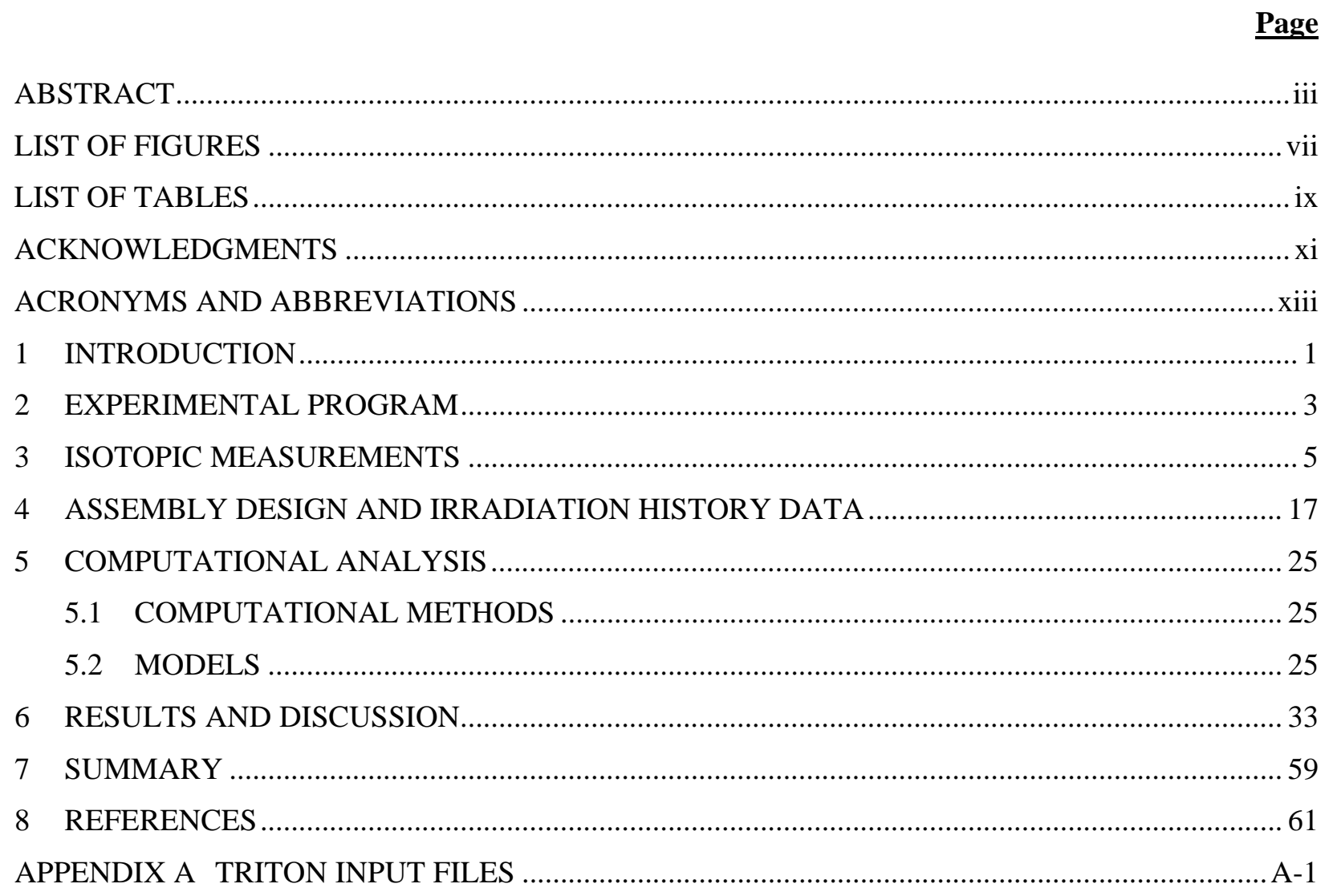




\section{LIST OF FIGURES}

Page

Figure 2.1. Locations of samples from rod WZR0058 (taken from Ref. 4)............................................. 4

Figure 4.1. Assembly layout for Vandellós II samples........................................................................ 19

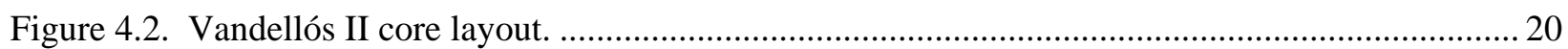

Figure 4.3. Boron concentration vs. irradiation time (from Ref. 9), ...................................................... 23

Figure 5.1. TRITON model for rod WZR0058 - cycle 7 ............................................................................ 27

Figure 5.2. TRITON model for rod WZR0058 - cycle 8. ......................................................................... 27

Figure 5.3. TRITON model for rod WZR0058 - cycle 9......................................................................... 28

Figure 5.4. TRITON model for rod WZR0058 - cycle 10 ................................................................. 29

Figure 5.5. TRITON model for rod WZR0058 - cycle 11................................................................... 30

Figure 5.6. Measured data for ${ }^{148} \mathrm{Nd}$ and ${ }^{137} \mathrm{Cs}$ vs. sample location for rod WZR0058........................... 32

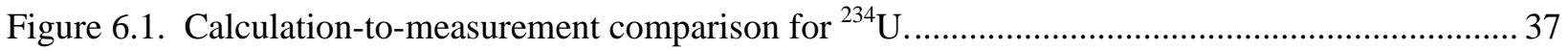

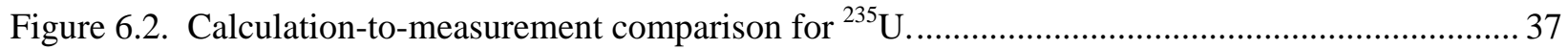

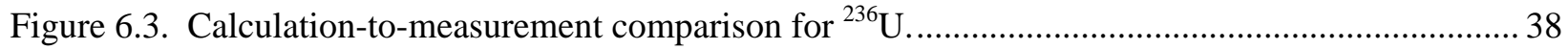

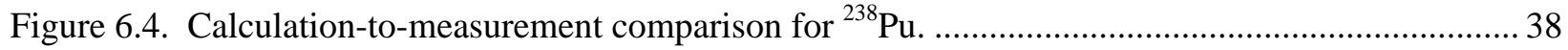

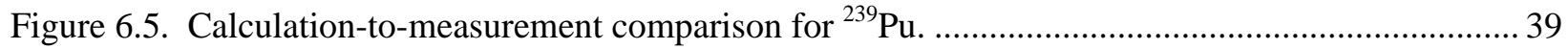

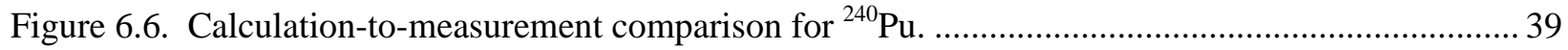

Figure 6.7. Calculation-to-measurement comparison for ${ }^{241} \mathrm{Pu}$...................................................... 40

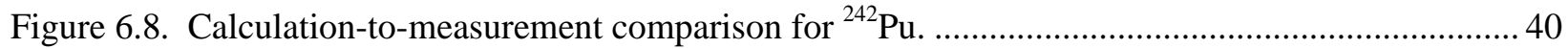

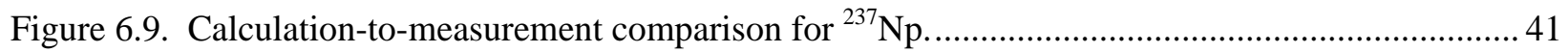

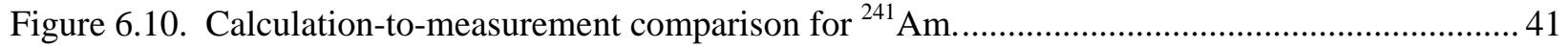

Figure 6.11. Calculation-to-measurement comparison for ${ }^{243} \mathrm{Am}$..................................................... 42

Figure 6.12. Calculation-to-measurement comparison for ${ }^{244} \mathrm{Cm}$.................................................... 42

Figure 6.13. Calculation-to-measurement comparison for ${ }^{246} \mathrm{Cm}$........................................................43

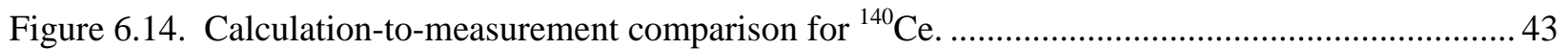

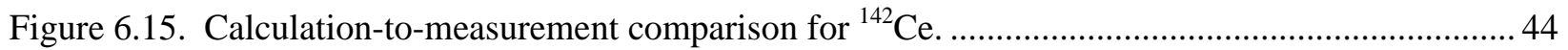

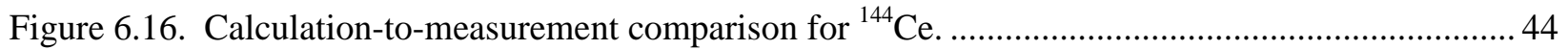

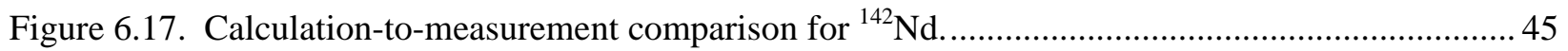

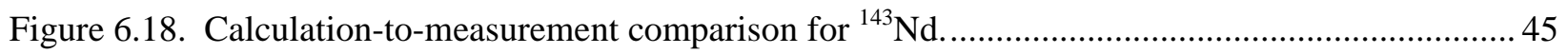

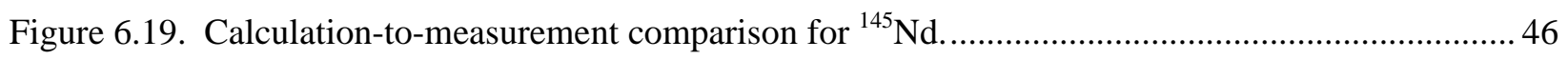

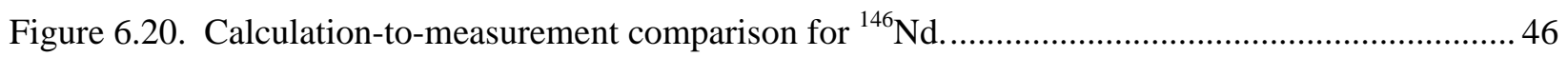

Figure 6.21. Calculation-to-measurement comparison for ${ }^{148} \mathrm{Nd}$...................................................... 47

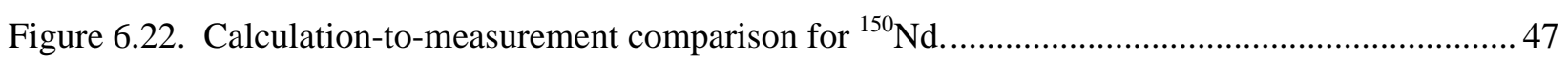




\section{LIST OF FIGURES (continued)}

Page

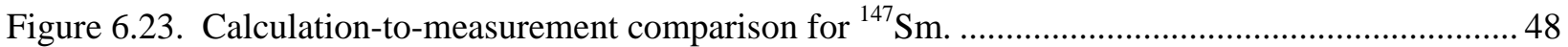

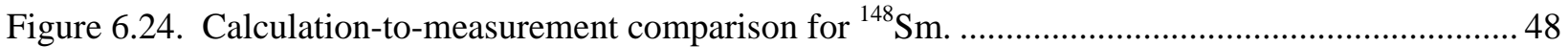

Figure 6.25. Calculation-to-measurement comparison for ${ }^{149} \mathrm{Sm}$. .......................................................... 49

Figure 6.26. Calculation-to-measurement comparison for ${ }^{150} \mathrm{Sm}$. ........................................................ 49

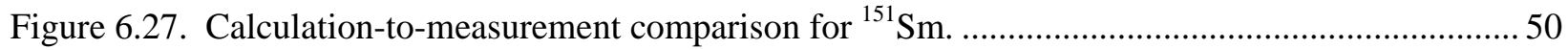

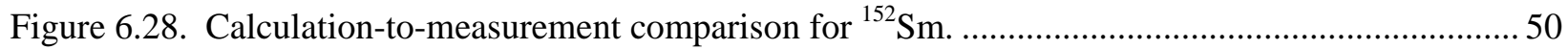

Figure 6.29. Calculation-to-measurement comparison for ${ }^{154} \mathrm{Sm}$....................................................... 51

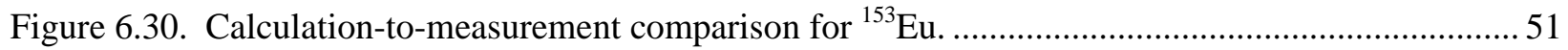

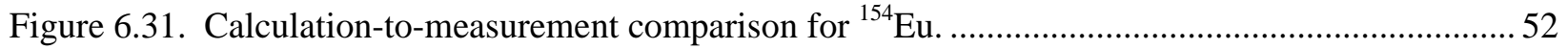

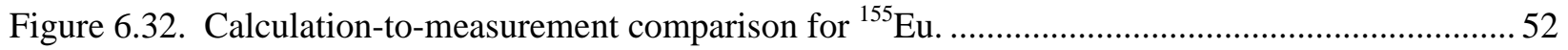

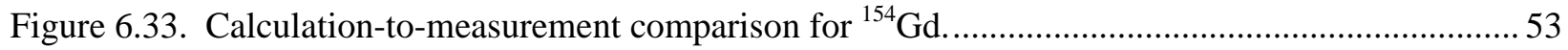

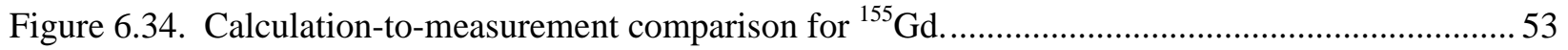

Figure 6.35. Calculation-to-measurement comparison for ${ }^{156} \mathrm{Gd}$........................................................ 54

Figure 6.36. Calculation-to-measurement comparison for ${ }^{158} \mathrm{Gd}$....................................................... 54

Figure 6.37. Calculation-to-measurement comparison for ${ }^{160} \mathrm{Gd}$........................................................ 55

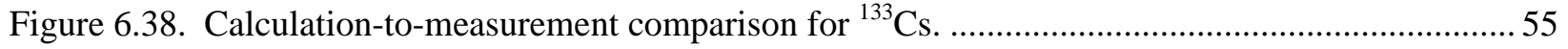

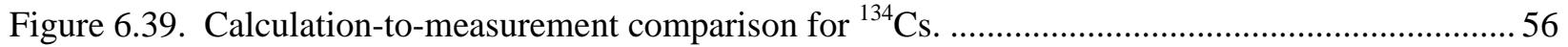

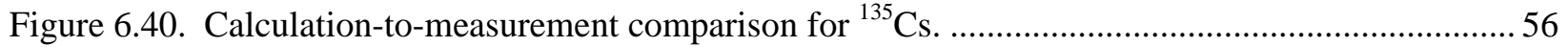

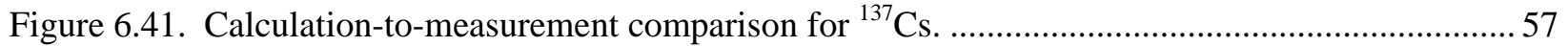

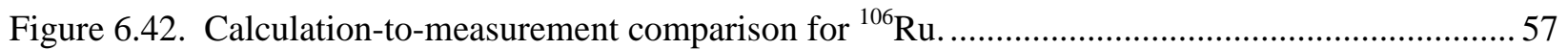

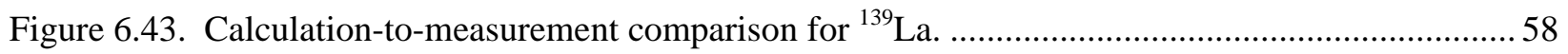

Figure 6.44. Calculation-to-measurement comparison for ${ }^{99}$ Tc.............................................................. 58 


\section{LIST OF TABLES}

Page

Table 1.1. Summary of spent fuel measurements ................................................................................ 2

Table 2.1. Vandellós II fuel samples............................................................................................. 3

Table 3.1. Experimental techniques and isotopic concentrations (in $\% \mathrm{~g} / \mathrm{g}^{238} \mathrm{U}$ ) for $1^{\text {st }}$ campaign.............. 9

Table 3.2. Experimental techniques and isotopic concentrations (in $\% g / \mathrm{g}^{238} \mathrm{U}$ ) for $2^{\text {nd }}$ campaign............ 11

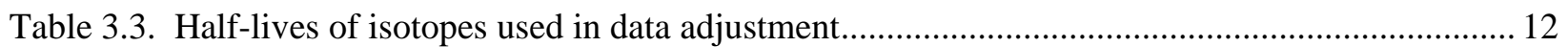

Table 3.4. Isotopic concentrations - combined data (in $\left.\% \mathrm{~g} / \mathrm{g}^{238} \mathrm{U}\right)$..................................................... 13

Table 3.5. Isotopic concentrations - combined data (in g/g $\left.\mathrm{U}_{\text {initial }}\right)$....................................................... 15

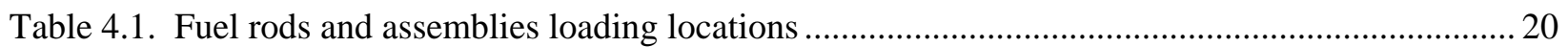

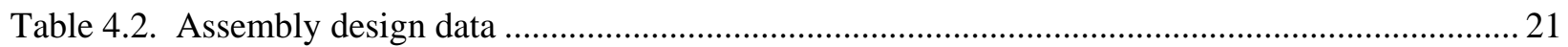

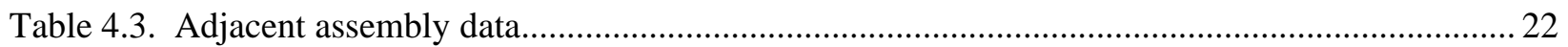

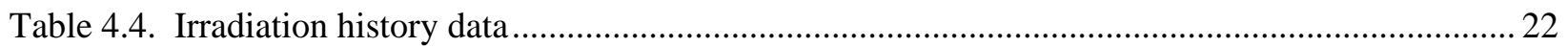

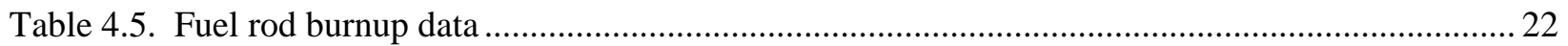

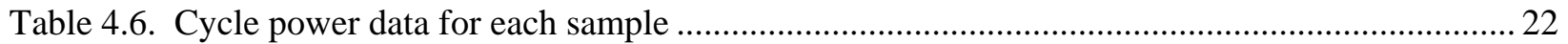

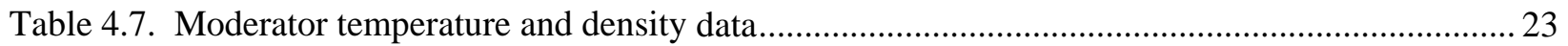

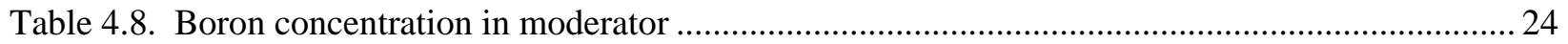

Table 5.1. Cycle power data based on measured sample burnups .......................................................... 31

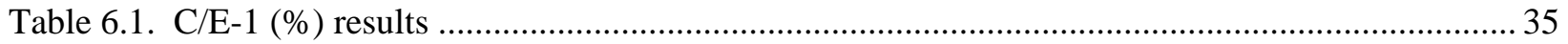




\section{ACKNOWLEDGMENTS}

This work was performed under contract with the U.S. Nuclear Regulatory Commission (NRC) under Project N6540, Neutronics for Reactor and Spent Nuclear Fuel. The authors would like to thank staff of the NRC Office of Nuclear Regulatory Research and the NRC Division of Spent Fuel and Transportation for their review and helpful comments and Mourad Aissa of the Office of Nuclear Regulatory Research for guidance and support. Review of the manuscript by Steve Bowman and Georgeta Radulescu at Oak Ridge National Laboratory and the careful formatting of this document by Debbie Weaver are appreciated and acknowledged. 


\section{ACRONYMS AND ABBREVIATIONS}

\begin{tabular}{|c|c|}
\hline ANL & Argonne National Laboratory \\
\hline ATM & Advanced Testing Materials \\
\hline ARIANE & 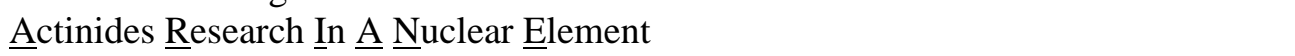 \\
\hline BOC & beginning of cycle \\
\hline $\mathrm{C} / \mathrm{E}$ & calculated-to-experimental \\
\hline CEA & Commisariat à l’Énergie Atomique \\
\hline CSN & Consejo de Seguridad Nuclear \\
\hline DOE & U.S. Department of Energy \\
\hline EFPD & effective full power days \\
\hline ENRESA & Empresa Nacional de Residuo Radioactivo, S. A. \\
\hline ENUSA & Empresa Nacional del Uranio, S. A. \\
\hline EOC & end of cycle \\
\hline GE-VNC & General Electric - Vallecitos Nuclear Center \\
\hline GKN II & Gemeinschaftskernkraftwerk Unit II \\
\hline HPLC & high pressure liquid chromatography \\
\hline ICP-MS & inductively coupled plasma mass spectrometry \\
\hline IDA & isotope dilution analysis \\
\hline ID-MS & isotope dilution mass spectrometry \\
\hline ITU & Institute for Transuranium Elements \\
\hline JAERI & Japanese Atomic Energy Research Institute \\
\hline KRI & Khoplin Radium Institute \\
\hline LA & luminescent analysis \\
\hline LWR & light water reactor \\
\hline MALIBU & 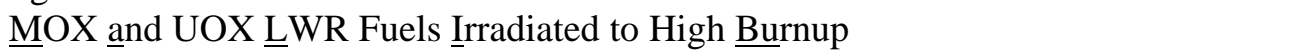 \\
\hline MOX & mixed oxide \\
\hline MS & mass spectrometry \\
\hline MTU & metric ton uranium ( $10^{6}$ grams $)$ \\
\hline NRC & U.S. Nuclear Regulatory Commission \\
\hline ORNL & Oak Ridge National Laboratory \\
\hline $\begin{array}{l}\text { PNNL } \\
\text { ppm }\end{array}$ & Pacific Northwest National Laboratory \\
\hline $\begin{array}{l}\text { Ppm } \\
\text { PSI }\end{array}$ & $\begin{array}{l}\text { parts per million } \\
\text { Paul Scherrer Institute }\end{array}$ \\
\hline PWR & pressurized water reactor \\
\hline REBUS & $\begin{array}{l}\text { Reactivity Tests for a Direct Evaluation of the Burnup Credit on Selected Irradiated } \\
\text { LWR Fuel Bundles }\end{array}$ \\
\hline SCALE & Standardized Computer Analyses for Licensing Evaluations \\
\hline SCK-CEN & Studiecentrum voor Kernenergie - Centre d'Étude de l'Energie Nucléaire \\
\hline TIMS & thermal ionization mass spectrometry \\
\hline TMI & Three Mile Island \\
\hline $\mathrm{UO}_{2}$ & uranium dioxide \\
\hline YMP & Yucca Mountain Project \\
\hline
\end{tabular}




\section{INTRODUCTION}

The current trend toward extended irradiation cycles and higher fuel enrichments approaching $5 \mathrm{wt} \%$

${ }^{235} \mathrm{U}$ has led to an increase of the burnup for discharged nuclear fuel assemblies in the United States, which now routinely exceeds $60 \mathrm{GWd} /$ metric ton uranium (MTU). Accurate analysis and evaluation of the uncertainties in the predicted isotopic composition for high-burnup spent nuclear fuel require rigorous computational tools and experimental data against which these tools can be benchmarked. However, the majority of isotopic assay measurements available to date involve spent fuel with burnups of less than $40 \mathrm{GWd} / \mathrm{MTU}$ and initial enrichments below $4 \mathrm{wt} \%{ }^{235} \mathrm{U}$, limiting the ability to validate computer code predictions and accurately quantify the uncertainties of isotopic analyses for modern fuels in the highburnup domain.

Quantifying and evaluating the uncertainty in spent fuel compositions is important for understanding and reducing the uncertainties associated with predicting the high-burnup fuel characteristics for spent fuel transportation and storage applications involving decay heat, radiation sources, and criticality safety evaluations with burnup credit, as well as for other reactor safety studies and accident consequence analyses.

This report documents the analyses performed by Oak Ridge National Laboratory (ORNL) of experimental data acquired from a Spanish high-burnup fuel program coordinated by the Spanish safety council for nuclear activities Consejo de Seguridad Nuclear (CSN), the Spanish fuel vendor Empresa Nacional del Uranio, S. A. (ENUSA), and Empresa Nacional de Residuo Radioactivo (ENRESA), the organization responsible for waste management in Spain. The assay measurements documented in this report include six spent fuel samples selected from three fuel rods with a $4.5 \mathrm{wt} \%{ }^{235} \mathrm{U}$ initial enrichment that were irradiated in the Vandellós II pressurized water reactor (PWR) operated in Spain. The samples cover a burnup range from 42 to $78 \mathrm{GWd} / \mathrm{MTU}$. Measurement cross-check data were available for three of the six samples.

This report is one of several recent NUREG/CR reports documenting the validation of the Standardized Computer Analyses for Licensing Evaluations (SCALE) code system against radiochemical assay measurements data. The experimental data included in the reports were compiled from domestic and international programs. The isotopic assay measurements include data for a total of 51 spent fuel samples selected from fuel rods enriched from 2.6 to $4.7 \mathrm{wt} \%{ }^{235} \mathrm{U}$ and irradiated in six different PWRs operated in Germany, Japan, Spain, Switzerland, and the United States. The samples cover a large burnup rangefrom 14 to $78 \mathrm{GWd} / \mathrm{MTU}$. A summary of the experimental programs and measured fuel characteristics is provided in Table 1.1. For consistency of the comparison, the validation studies against the measurement data shown in Table 1.1 were all carried out using SCALE 5.1 codes and nuclear data.

A brief description of the Spanish experimental program is given in Section 2 of this report. The main radiochemical methods employed, the measurement results, and the associated experimental uncertainties are provided in Section 3. Information on the assembly design data and irradiation history is presented in Section 4, and details on the computational models developed and simulation methodology used are shown in Section 5. A comparison of the experimental data with the results obtained from code simulations is presented in Section 6. 
Table 1.1. Summary of spent fuel measurements

\begin{tabular}{|c|c|c|c|c|c|c|c|}
\hline $\begin{array}{l}\text { Reactor } \\
\text { (country) }\end{array}$ & $\begin{array}{l}\text { Measurement } \\
\text { facility }\end{array}$ & $\begin{array}{c}\text { Experimental } \\
\text { program name }\end{array}$ & $\begin{array}{c}\text { Assembly } \\
\text { design }\end{array}$ & $\begin{array}{l}\text { Enrichment } \\
\text { (wt } \%{ }^{235} U \text { ) }\end{array}$ & $\begin{array}{c}\text { No. of } \\
\text { samples }\end{array}$ & $\begin{array}{l}\text { Measurement } \\
\text { methods }\end{array}$ & $\begin{array}{c}\text { Burnup(s) }^{a} \\
\text { (GWd/MTU) }^{\text {GWd }}\end{array}$ \\
\hline $\begin{array}{l}\text { TMI-1 }^{b} \\
\text { (USA) }\end{array}$ & $\begin{array}{l}\text { ANL } \\
\text { (USA) }\end{array}$ & YMP & $15 \times 15$ & 4.013 & 11 & $\begin{array}{c}\text { ICP-MS, } \\
\alpha \text {-spec, } \gamma \text {-spec }\end{array}$ & $44.8-55.7$ \\
\hline $\begin{array}{l}\text { TMI-1 }^{b} \\
\text { (USA) }\end{array}$ & $\begin{array}{c}\text { GE-VNC } \\
\text { (USA) }\end{array}$ & YMP & $15 \times 15$ & 4.657 & 8 & $\begin{array}{c}\text { TIMS, } \\
\alpha \text {-spec, } \gamma \text {-spec }\end{array}$ & $22.8-29.9$ \\
\hline $\begin{array}{c}\text { Calvert } \text { Cliffs }^{b} \\
\text { (USA) }\end{array}$ & $\begin{array}{c}\text { PNNL, KRI } \\
\text { (USA, Russia) }\end{array}$ & ATM & $14 \times 14 \mathrm{CE}$ & 3.038 & 3 & $\begin{array}{c}\text { ID-MS, LA, } \\
\alpha \text {-spec, } \gamma \text {-spec } \\
\end{array}$ & $27.4,37.1,44.3$ \\
\hline $\begin{array}{c}\text { Takahama } 3^{b} \\
\text { (Japan) }\end{array}$ & $\begin{array}{l}\text { JAERI } \\
\text { (Japan) }\end{array}$ & JAERI & $17 \times 17$ & $2.63,4.11$ & 16 & $\begin{array}{c}\text { ID-MS, } \\
\alpha \text {-spec, } \gamma \text {-spec }\end{array}$ & $14.3-47.3$ \\
\hline $\begin{array}{c}\text { Gösgen }^{c} \\
\text { (Switzerland) }\end{array}$ & $\begin{array}{c}\text { SCK-CEN, ITU } \\
\text { (Belgium, Germany) }\end{array}$ & ARIANE & $15 \times 15$ & $3.5,4.1$ & 3 & $\begin{array}{l}\text { TIMS, ICP-MS, } \\
\alpha \text {-spec, } \beta \text {-spec, } \gamma \text { - } \\
\text { spec }\end{array}$ & $29.1,52.5,59.7$ \\
\hline $\begin{array}{c}\text { GKN II } \\
\text { (Germany) }\end{array}$ & $\begin{array}{l}\text { SCK-CEN } \\
\text { (Belgium) }\end{array}$ & REBUS & $18 \times 18$ & 3.8 & 1 & $\begin{array}{l}\text { TIMS, ICP-MS } \\
\alpha \text {-spec, } \gamma \text {-spec }\end{array}$ & 54.0 \\
\hline $\begin{array}{c}\text { Gösgen }^{d} \\
\text { (Switzerland) }\end{array}$ & $\begin{array}{l}\text { SCK-CEN, CEA, PSI } \\
\text { (Belgium, France, } \\
\text { Switzerland) }\end{array}$ & MALIBU & $15 \times 15$ & 4.3 & 3 & $\begin{array}{l}\text { TIMS, ICP-MS, } \\
\alpha \text {-spec, } \gamma \text {-spec }\end{array}$ & $46.0,50.8,70.3$ \\
\hline $\begin{array}{c}\text { Vandellós II }{ }^{e} \\
\text { (Spain) }\end{array}$ & $\begin{array}{l}\text { Studsvik } \\
\text { (Sweden) }\end{array}$ & CSN/ENUSA & $17 \times 17$ & 4.5 & 6 & ICP-MS, $\gamma$-spec & $42.5-78.3$ \\
\hline
\end{tabular}

${ }^{a}$ Correspond to operator-based values, as reported, except for data for MALIBU and CSN/ENUSA programs samples, which correspond to measured data for burnup indicators.

${ }^{b}$ Documented in G. Ilas, I. C. Gauld, F. C. Difilippo, and M. B. Emmett, Analysis of Experimental Data for High Burnup PWR Spent Fuel Isotopic Validation-Calvert Cliffs, Takahama, and Three Mile Island Reactors, NUREG/CR-6968 (ORNL/TM-2008/071), prepared for the U.S. Nuclear Regulatory Commission by Oak Ridge National Laboratory, Oak Ridge, Tennessee (2009).

${ }^{\mathrm{c}}$ Documented in G. Ilas, I. C. Gauld, and B. D. Murphy, Analysis of Experimental Data for High Burnup PWR Spent Fuel Isotopic Validation-ARIANE and REBUS Programs (UO ${ }_{2}$ Fuel),

NUREG/CR-6969 (ORNL/TM-2008/072), prepared for the U.S. Nuclear Regulatory Commission by Oak Ridge National Laboratory, Oak Ridge, Tennessee (2009).

${ }^{d}$ Details about the MALIBU program can be found in MALIBU Program - Radiochemical Analysis of MOX and UOX LWR Fuels Irradiated to High Burnup, Belgonucleaire Technical Proposal,

MA 2001/02, Belgonucleaire, Brussels, Belgium (September 2001).

${ }^{e}$ Documented in current report. 


\section{EXPERIMENTAL PROGRAM}

Assay data have been acquired and evaluated by ORNL, under support of the U.S. Nuclear Regulatory Commission (NRC), for high-burnup samples selected from three fuel rods irradiated in the Vandellós II PWR operated in Spain. This experimental program (Refs. 1-2) was coordinated by the Spanish safety council for nuclear activities, CSN, in collaboration with Spanish fuel vendor ENUSA and ENRESA, the organization responsible for waste management in Spain. The fuel isotopic measurements were performed at the laboratory of Studsvik Nuclear AB located in Nykoping, Sweden.

The Vandellós II samples were selected from three fuel rods identified as WZR0058, WZtR165, and WZtR160, which were taken from two fuel assemblies. Each of these three rods had an initial enrichment of $4.5 \mathrm{wt} \%{ }^{235} \mathrm{U}$. The rods were irradiated in the reactor for five consecutive cycles, from cycle 7 to cycle 11. During the first four of the five irradiation cycles, rods WZR0058 and WZtR165 were located in the same fuel assembly, EC45, whereas rod WZtR160 was located in assembly EC46. For their last cycle, these three rods were removed from their original assemblies and inserted into different positions of rebuilt assembly EF05. The irradiation histories of rods WZtR160, WZR0058, and WZtR165 were similar and resulted in calculated final rod-average burnup of 66.5, 68.5, and 70.0 MWd/MTU, respectively. Details on the irradiation history are provided in Section 4.

The experimental program was carried out in two measurement campaigns:

- Phase 1, performed in 2002-2003 (Refs. 3-5), included measurements of seven samples from rods WZR0058 and WZtR165.

- $\quad$ Phase 2, performed in 2007 (Ref. 6), included reanalysis of two fuel sample solutions from the first campaign and measurements for two new samples from rods WZR0058 and WZtR160.

One sample was selected for analysis from each of the fuel rods WZtR165 and WZtR160, whereas seven fuel segments were selected from rod WZR0058. The locations of the samples with respect to the bottom of the active fuel region and the sample burnups are shown in Table 2.1. The locations of the samples selected from rod WZR0058 are illustrated in Figure 2.1. Three of the samples from rod WZR0058, measured in the first campaign and identified as E58-773, E58-793, and E58-796, were cut within a $23 \mathrm{~mm}$ section of the fuel rod in a relatively uniform high-burnup region of the rod. These samples all had the same burnup based on the gamma scan of the rod and are considered sister samples for analysis purposes, as discussed further in this section. These samples provide a measure of the experimental accuracy for all phases of the experimental procedures, including independent cutting, dissolution, separations, and radiochemical analysis.

Table 2.1. Vandellós II fuel samples

\begin{tabular}{|c|c|c|c|c|c|c|c|c|c|c|c|}
\hline Rod ID & \multicolumn{9}{|c|}{ WZR0058 } & WZtR165 & WZtR160 \\
\hline Sample ID & \multicolumn{2}{|c|}{ E58-88 } & E58-148 & E58-263 & E58-257 & E58-773 & \multicolumn{2}{|c|}{ E58-793 } & E58-796 & $165-2 \mathrm{a}$ & $160-800$ \\
\hline $\begin{array}{l}\text { Axial } \\
\text { location }^{a} \\
(\mathrm{~mm})\end{array}$ & \multicolumn{2}{|c|}{88} & 148 & 263 & 257 & 773 & \multicolumn{2}{|c|}{793} & 796 & 797 & 1060 \\
\hline Campaign & I & II & I & I & II & I & I & II & $\mathrm{I}$ & $\mathrm{I}$ & II \\
\hline $\begin{array}{l}\text { Combined } \\
\text { sample ID }\end{array}$ & \multicolumn{2}{|c|}{ E58-88 } & E58-148 & \multicolumn{2}{|c|}{ E58-260 } & \multicolumn{4}{|c|}{ E58-700 } & $165-2 a$ & $160-800$ \\
\hline $\begin{array}{l}\text { Burnup }^{b} \\
\text { (GWd/MTU) }\end{array}$ & \multicolumn{2}{|c|}{42.5} & 54.8 & \multicolumn{2}{|c|}{64.6} & \multicolumn{4}{|c|}{77.0} & 78.3 & 70.9 \\
\hline
\end{tabular}

${ }^{a}$ With respect to the bottom of the active fuel region.

${ }^{b}$ Burnup based on measured data for burnup-indicator fission products ${ }^{148} \mathrm{Nd}$ and ${ }^{137} \mathrm{Cs}$, as discussed in Section 5 of this report. 
A second phase of the project was carried out with support of ORNL and the NRC to provide additional cross-check measurements and to better evaluate and reduce the uncertainties in the data obtained from the first phase. In the second phase, instrumentation with increased accuracy was used to repeat the measurements in some of the samples measured in the first campaign to resolve discrepancies observed for some isotopes and include some metallic isotopes not present in the first set of measurements. In addition to the reanalysis of two fuel sample solutions from the first campaign, a new fuel sample from rod WZR0058 was measured in the second campaign; this sample, identified as E58-257, was selected from a position adjacent to one (i.e., E68-263) of the first-campaign samples to provide confirmatory analysis of the measurement procedures, including cutting and fuel dissolution. Also, a new high-burnup (>70 GWd/t) sample from rod WZtR160 was examined.

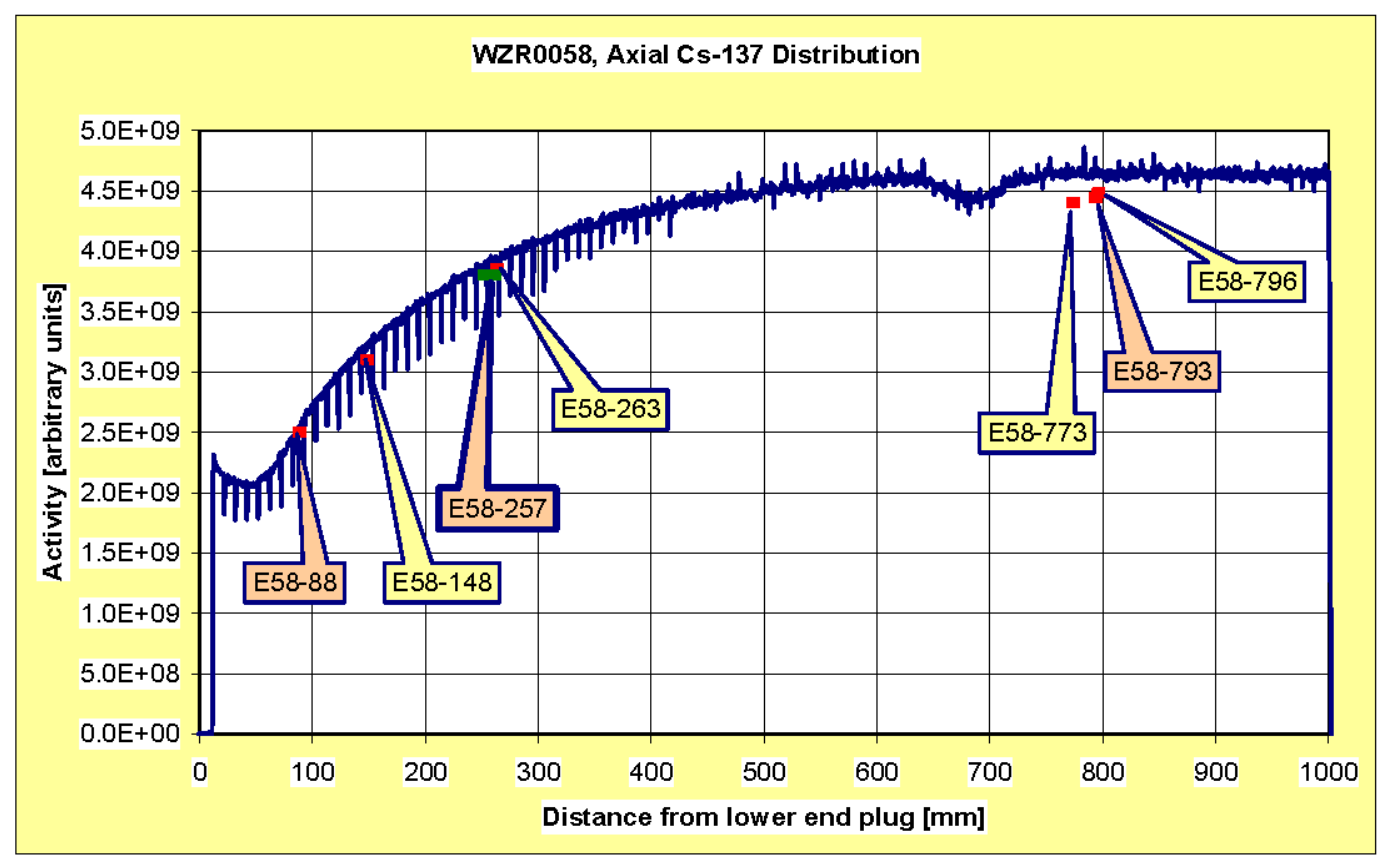

Figure 2.1. Locations of samples from rod WZR0058 (taken from Ref. 4). 


\section{ISOTOPIC MEASUREMENTS}

The measurements were carried out by Studsvik in two experimental campaigns: Phase 1 measurements performed in 2002-2003 and Phase 2 measurements performed in 2007. The experiments in 2002-2003 were carried out for the samples identified as E58-88, E58-148, E58-263, E58-773, E58-793, E58-796, and 165-2a. Updated reports describing the 2003 experiments were issued later to address some inconsistencies observed in fuel handling and correlate the measured data to the actual rod identities. As part of the second experimental campaign at Studsvik, new measurements were performed to increase the number of available samples and confirm the accuracy of the previous measurements using improved instruments with increased accuracy. Reanalyses of samples E58-88 and E58-793 were carried out in the second campaign using solutions available from the 2003 measurement campaign. Two new samples were measured in 2007: one sample identified as E58-257, cut from rod WZR0058, and one sample identified as 160-800, cut from rod WZtR160.

High-performance liquid chromatography (HPLC) combined with an inductively coupled plasma mass spectrometer (ICP-MS) and ICP-MS without chemical separations were used at Studsvik Nuclear AB for the analysis of about 45 individual isotopes in a total of 9 samples. Fuel inventories of six additional fission product radionuclides with suitably long half-lives and gamma lines were determined based on gamma scans of the fuel rod.

The following main experimental techniques have been applied for measurements performed at Studsvik in Sweden:

- ICP-MS with isotope dilution analysis (IDA)

o actinides: $\mathrm{U}, \mathrm{Pu}, \mathrm{Am}$

○ lanthanides: Ce, Nd, Sm, Eu, Gd

○ metallics: ${ }^{95,97,98,100} \mathrm{Mo}$

- ICP-MS with external calibration

○ metallics: ${ }^{99} \mathrm{Tc},{ }^{103} \mathrm{Rh}$

○ actinides: ${ }^{237} \mathrm{~Np},{ }^{244,246} \mathrm{Cm}$

○ lanthanides: ${ }^{139} \mathrm{La}$

$\circ$ fission products: ${ }^{133} \mathrm{Cs},{ }^{135} \mathrm{Cs}$

- $\gamma$-spectrometry

$$
\text { ○ }{ }^{103,106} \mathrm{Ru},{ }^{134,137} \mathrm{Cs},{ }^{144} \mathrm{Ce},{ }^{154} \mathrm{Eu}
$$

Only the main techniques are summarized above. Some nuclides required multiple techniques to eliminate interferences. The measurements in the second campaign included more nuclides than measured in the first campaign: ${ }^{103} \mathrm{Rh},{ }^{139} \mathrm{La},{ }^{99} \mathrm{Tc}$, and ${ }^{95,97,98,100} \mathrm{Mo}$. The ${ }^{135} \mathrm{Cs}$ isotope was not measured in the second campaign.

The measurement data as reported for the first campaign are shown in Table 3.1. The isotopic data were reported as weight percent relative to measured ${ }^{238} \mathrm{U}$. Data for most of the measured nuclides were reported at the time of measurement. Data from the $\gamma$-spectrometry were reported at discharge time. Data for isotopes measured by ICP-MS with external calibration correspond to a decay time of 1110 days, and data for isotopes measured by ICP-MS with IDA correspond to 1101 days decay time. For the three samples E58-773, E58-793, and E58-796 selected from a $23 \mathrm{~mm}$ length fuel segment the high-burnup region of rod WZR0058, which had effectively the same burnup, the reported data for these samples were compared to check measurement consistency. It was found that for 42 of the 44 measured isotopes, the measured concentrations were compatible at the $95 \%$ confidence level (i.e., the data agree within $2 \sigma$ ). 
The data for the other two measured isotopes, ${ }^{243} \mathrm{Am}$ and ${ }^{154} \mathrm{Eu}$, agreed within $3 \sigma$. Therefore, these samples can be considered sister samples based on the similarity of the measurement data.

The data for the second measurement campaign, as reported, are shown in Table 3.2. The data include isotopic concentrations for two new samples, identified as 160-800 and E58-257, and isotopic concentrations measured in old solutions for samples E58-88 and E58-793 that were available from the first measurement campaign. The data from the $\gamma$-spectrometry were reported at discharge time. The second-campaign data for isotopes measured by ICP-MS with external calibration correspond to a decay time of $2298 \mathrm{~d}$, and the data for isotopes measured by ICP-MS with IDA correspond to a $2334 \mathrm{~d}$ decay time. Some of the measurements from this second campaign were carried out with new, better-precision instruments than those used in the first campaign. The measured isotopic concentrations and the corresponding uncertainties were reported as weight percent relative to the measured content of ${ }^{238} \mathrm{U}$.

An evaluation of the experimental data from the two separate measurement campaigns was performed as part of the work for the current report. Second-campaign results for sample E58-88, which was measured using a sample solution from the first campaign, were combined with results available from the first campaign after an evaluation of the data for consistency. In addition, first-campaign measurement data for samples E58-773 and E58-796 were combined with the two separate measurements of sample E58-793 to form a single dataset identified as sample E58-700. Second-campaign measurements on sample E58-257 were also combined with the first-campaign results for sample E58-263. Sample E58-257 was cut from a position adjacent to that of sample E58-263, and the samples had the same burnup based on operator data. The size of sample E58-257 $(10 \mathrm{~mm})$ was larger than most of the other samples $(2 \mathrm{~mm})$. The maximum estimated burnup difference based on the ${ }^{137} \mathrm{Cs}$ gamma scan data for these two samples was estimated to be less than $1 \%$, which was less than the uncertainty on the burnup determination using destructive analysis data.

As part of the data evaluation procedure, measurement results for most second-campaign data were first back-calculated to the time of the first-campaign measurement dates to provide a consistent basis for comparing and combining the measurement data from both campaigns. The adjustment of the data from the second campaign accounted for the decay of the measured nuclides and the contributions from decay precursors. Measurements for ${ }^{144} \mathrm{Nd}$ from the second campaign could not be adjusted for all samples because the precursor ${ }^{144} \mathrm{Ce}$ was not measured in them all. Similarly, ${ }^{147} \mathrm{Sm}$ data from the second campaign were not used because the precursor ${ }^{147} \mathrm{Pm}$ was not measured in any of the samples, and therefore properly accounting for the decay time was not possible.

The half-lives used to adjust data to account for the different measurement times are listed in Table 3.3. These data are based on ENDF/B-VI nuclear data and are the same values as used in the code simulations.

The combination of the data (Ref. 7) was done as shown in Eq. (3.1), where $x_{i}$ and $\sigma_{i}(i=1, \mathrm{n})$ are, respectively, the reported measured isotopic content and reported corresponding uncertainty (at 95\% confidence level) for a given isotope, and $\bar{X}$ and $\sigma$ are, respectively, the combined measured isotopic content and corresponding uncertainty for that isotope.

$$
\bar{x}=\frac{\sum_{i=1}^{n} \frac{x_{i}}{\sigma_{i}^{2}}}{\sum_{i=1}^{n} \frac{1}{\sigma_{i}^{2}}} \quad \text { and } \quad \sigma^{2}=\frac{1}{\sum_{i=1}^{n} \frac{1}{\sigma_{i}^{2}}}
$$

The experimental data were compared at the 95\% confidence level, corresponding to two standard deviations in the measurement uncertainty reported by the laboratory. Multiple measurements for a 
sample that agreed within this level were combined according to Eq. (3.1) using the measurement uncertainty to weight the different measurements. For nuclides that did not agree within the uncertainties, additional evaluations of the data were performed, as discussed below. The combined data are shown in Table 3.4. To facilitate a consistent comparison, the uncertainty data shown for all samples in Table 3.4 correspond to a $95 \%$ confidence level.

Uranium measurements from the second campaign were not recommended or used in this study. The IDA results for ${ }^{235} U$ and ${ }^{236} U$ were systematically higher in the second campaign compared to the first and higher than ICP-MS with external calibration results (Ref. 6). This change was later traced by the laboratory to an instrumentation error in the second campaign.

Neodymium IDA results from the first measurement campaign for samples E58-88 and E58-263 were removed from the dataset. Large systematic differences were observed between Phase 1 and Phase 2 results for several neodymium isotopes for these two samples. In addition, the sample burnup based on first-phase ${ }^{148} \mathrm{Nd}$ results were not consistent with the sample burnup determined from ${ }^{137} \mathrm{Cs}$ gamma scanning. For these two samples, only neodymium data from the second measurement campaign were used. The ${ }^{142} \mathrm{Nd}$ result for sample 165 -2a was removed from the dataset, as it was significantly out of trend (lower by 25\%) compared to corresponding results from all other similar burnup samples.

Second-campaign ${ }^{241}$ Am measurements for samples E58-88 and E58-793 were not included in the final dataset because the results were two times larger than the first-campaign results for the same two samples and larger than the second-campaign results for the two new samples. The results were also inconsistent with the ${ }^{241} \mathrm{Am}$ concentration that would be produced from the decay of ${ }^{241} \mathrm{Pu}$, indicating measurement problems. The removed measurements corresponded to the two reanalyzed solutions, indicating the problem could have been related to instability over time of these solutions.

The ${ }^{243} \mathrm{Am}$ results for sample E58-793, measured in both campaigns, did not agree within the 95\% confidence level with the results for similar samples E58-796 and E58-773. The E58-793 results appeared to be out of trend; however, the difference was judged to be insufficient for removing the data for sample E58-793. Rather, the results for all four measurements from the two campaigns for the sample identified as E58-700 were combined, and the uncertainty was increased by a factor of two.

The ${ }^{142} \mathrm{Ce}$ and ${ }^{149} \mathrm{Sm}$ results for samples E58-257 and E58-263 were found to be inconsistent at the 95\% confidence range. Likewise, the second-campaign ${ }^{160} \mathrm{Gd}$ results for sample E58-793 were inconsistent compared to results for sample E58-796. The ${ }^{154}$ Sm results from the second campaign for sample E58793 were also found to be inconsistent with the first-campaign results for the three samples E58-793, E58-796, and E58-773. In most of these cases, though, the differences were only slightly larger than the 95\% confidence range. Consequently, the results for these samples were combined and the associated uncertainty similarly increased by a factor of two.

Second-campaign results for ${ }^{155} \mathrm{Gd}$ were observed to be erratic and biased by more than $50 \%$ compared to the first-campaign results. Because the concentration of ${ }^{155} \mathrm{Gd}$ is determined almost entirely from the decay of ${ }^{155} \mathrm{Eu}$, the expected ${ }^{155} \mathrm{Gd}$ can be analytically calculated. Based on this calculation, the Phase 2 ${ }^{155} \mathrm{Gd}$ data were determined to be incorrect and removed from the final dataset.

Europium data from the second measurement campaign were not used. Results for ${ }^{153} \mathrm{Eu}$, the most abundant europium isotope, exhibited a 20\% discrepancy between Phases 1 and 2. The spike solution used in the Phase 1 measurements was reanalyzed and the initial results adjusted accordingly by Studsvik. However, no basis for performing a similar adjustment of the Phase 2 data was identified (Ref. 6). The results for ${ }^{151}$ Eu were not used from either campaign due to erratic behavior of the data, likely due to very low concentrations that resulted in larger uncertainties than actually reported. 
The ${ }^{133}$ Cs data for the two new samples E58-257 and 160-800 measured in the second campaign were not considered due to a reported loss of cesium from the solutions for these two samples (Ref. 6). The ${ }^{103} \mathrm{Rh}$ data for sample E58-257 were removed due to suspected incomplete recovery of the metallic nuclide in solution. Similarly, the ${ }^{99}$ Tc data for samples E58-257 and E58-793 were removed due to recovery problems (Ref. 6). The molybdenum data were not considered as it was discovered that these measurements were contaminated by natural molybdenum (Ref. 6).

For comparison to measured data obtained from other experimental programs, the experimental data shown in Table 3.4 were also expressed in units of $\mathrm{g} / \mathrm{g} \mathrm{U}_{\text {initial, }}$, as shown in Table 3.5, using the initial uranium content in the sample as a basis. The concentration in $\mathrm{g} / \mathrm{g} \mathrm{U}_{\text {initial }}$ of nuclide $i$ was determined as (Ref. 8)

$$
\frac{m_{i}}{\sum_{k} m_{U_{k}}+\sum_{l} m_{P u_{l}}+\sum_{m} m_{A m_{m}}+\sum_{n} m_{C m_{n}}+238 \frac{m_{148} N d}{148 \bar{Y}}}
$$

where $m_{i}$ is the mass of isotope $i$ reported in $\% g / g{ }^{238} \mathrm{U}$ measured. The denominator in Eq. (3.2) is the derived value for the initial uranium content, calculated as a sum of the measured heavy metal isotopes (uranium, plutonium, americium, and curium) masses in the sample and the heavy metal mass loss due to burnup. The reduction in heavy metal mass due to burnup is approximated by $238 \frac{\boldsymbol{m}_{148_{N d}}}{148 \overline{\boldsymbol{Y}}}$, where $\bar{Y}$ is a

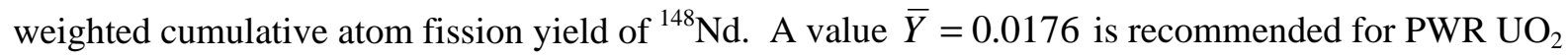
fuel (Ref. 8). Note that $m_{U_{238}}=100$ in Eq. (3.2) because all measurements were reported in percentage relative to measured ${ }^{238} \mathrm{U}$ in the samples. No error propagation was carried out on the ratio in Eq. (3.2) as any additional error associated with the unit conversion is extremely small relative to the reported measurement uncertainties. 
Table 3.1. Experimental techniques and isotopic concentrations (in $\% \mathrm{~g} / \mathrm{g}^{238} \mathrm{U}$ ) for $\mathbf{1}^{\text {st }}$ campaign

\begin{tabular}{|c|c|c|c|c|c|c|c|c|c|c|c|c|c|c|c|}
\hline \multicolumn{2}{|c|}{ Sample ID } & \multirow{2}{*}{\multicolumn{2}{|c|}{$\begin{array}{c}\text { E58-88 } \\
42.5 \\
\end{array}$}} & \multirow{2}{*}{\multicolumn{2}{|c|}{$\begin{array}{c}\text { E58-148 } \\
54.8 \\
\end{array}$}} & \multirow{2}{*}{\multicolumn{2}{|c|}{$\begin{array}{c}\text { E58-263 } \\
64.6\end{array}$}} & \multirow{2}{*}{\multicolumn{2}{|c|}{$\begin{array}{c}\text { E58-773 } \\
77.0 \\
\end{array}$}} & \multirow{2}{*}{\multicolumn{2}{|c|}{$\begin{array}{c}\text { E58-793 } \\
77.0 \\
\end{array}$}} & \multirow{2}{*}{\multicolumn{2}{|c|}{$\begin{array}{c}\text { E58-796 } \\
77.0 \\
\end{array}$}} & \multirow{2}{*}{\multicolumn{2}{|c|}{$\begin{array}{c}165-2 a \\
78.3 \\
\end{array}$}} \\
\hline Burnup $^{a}$ & $(G W d / t)$ & & & & & & & & & & & & & & \\
\hline Nuclide $^{b}$ & Method $^{c}$ & $\begin{array}{c}\text { Mass }^{d} \\
\% \mathrm{~g} / \mathrm{g}^{238} \mathbf{U}\end{array}$ & $\begin{array}{c}2 \sigma^{d} \\
\% \mathrm{~g} / \mathrm{g}^{238} \mathrm{U}\end{array}$ & $\begin{array}{c}\text { Mass } \\
\% \mathrm{~g} / \mathrm{g}^{238} \mathrm{U}\end{array}$ & $\begin{array}{c}2 \sigma \\
\% \mathrm{~g} / \mathrm{g}^{238} \mathrm{U}\end{array}$ & $\begin{array}{c}\text { Mass } \\
\% \mathrm{~g} / \mathbf{g}^{338} \mathrm{U}\end{array}$ & $\begin{array}{c}2 \sigma \\
\% \mathrm{~g} / \mathrm{g}^{238} \mathrm{U} \\
\end{array}$ & $\begin{array}{c}\text { Mass } \\
\% \mathrm{~g} / \mathrm{g}^{238} \mathrm{U}\end{array}$ & $\begin{array}{c}2 \sigma \\
\% \mathrm{~g} / \mathrm{g}^{238} \mathrm{U}\end{array}$ & $\begin{array}{c}\text { Mass } \\
\% \mathrm{~g} / \mathrm{g}^{238} \mathrm{U}\end{array}$ & $\begin{array}{c}2 \sigma \\
\% \mathrm{~g} / \mathrm{g}^{238} \mathrm{U} \\
\end{array}$ & $\begin{array}{c}\text { Mass } \\
\% \mathrm{~g} / \mathrm{g}^{238} \mathrm{U}\end{array}$ & $\begin{array}{c}2 \sigma \\
\% \mathrm{~g} / \mathrm{g}^{238} \mathrm{U} \\
\end{array}$ & $\begin{array}{c}\text { Mass } \\
\% \mathrm{~g} / \mathrm{g}^{\mathbf{2 3 8}} \mathrm{U}\end{array}$ & $\begin{array}{c}2 \sigma \\
\% \mathrm{~g} / \mathrm{g}^{238} \mathrm{U}\end{array}$ \\
\hline U-234 & ICP-MS IDA & 0.0245 & 0.0044 & 0.0232 & 0.0034 & 0.0161 & 0.0064 & 0.0136 & 0.0036 & 0.0150 & 0.0066 & 0.0152 & 0.0038 & 0.0140 & 0.0038 \\
\hline U-235 & ICP-MS IDA & 1.328 & 0.148 & 0.921 & 0.064 & 0.525 & 0.072 & 0.321 & 0.032 & 0.312 & 0.054 & 0.320 & 0.030 & 0.294 & 0.026 \\
\hline U-236 & ICP-MS IDA & 0.568 & 0.056 & 0.687 & 0.050 & 0.677 & 0.090 & 0.645 & 0.058 & 0.684 & 0.094 & 0.671 & 0.050 & 0.681 & 0.050 \\
\hline Pu-238 & ICP-MS IDA & 0.0281 & 0.0020 & 0.0402 & 0.0054 & 0.0651 & 0.007 & 0.0884 & 0.0084 & 0.0977 & 0.0136 & 0.0859 & 0.010 & 0.0971 & 0.0096 \\
\hline Pu-239 & ICP-MS IDA & 0.652 & 0.032 & 0.642 & 0.044 & 0.640 & 0.064 & 0.676 & 0.046 & 0.724 & 0.084 & 0.679 & 0.048 & 0.741 & 0.044 \\
\hline Pu-240 & ICP-MS IDA & 0.250 & 0.012 & 0.293 & 0.020 & 0.327 & 0.032 & 0.372 & 0.026 & 0.395 & 0.052 & 0.385 & 0.028 & 0.404 & 0.026 \\
\hline Pu-241 & ICP-MS IDA & 0.140 & 0.008 & 0.160 & 0.012 & 0.182 & 0.018 & 0.199 & 0.014 & 0.216 & 0.030 & 0.205 & 0.018 & 0.221 & 0.014 \\
\hline Pu-242 & ICP-MS IDA & 0.0574 & 0.0032 & 0.0920 & 0.0066 & 0.1370 & 0.0138 & 0.1864 & 0.0136 & 0.1994 & 0.0276 & 0.1853 & 0.0144 & 0.2095 & 0.0130 \\
\hline Np-237 & ICP-MS ext & 0.073 & 0.012 & 0.100 & 0.016 & 0.130 & 0.022 & 0.127 & 0.020 & 0.117 & 0.018 & 0.122 & 0.020 & 0.140 & 0.022 \\
\hline Am-241 & ICP-MS IDA & 0.026 & 0.002 & 0.029 & 0.002 & 0.032 & 0.004 & 0.036 & 0.002 & 0.031 & 0.004 & 0.033 & 0.002 & 0.037 & 0.002 \\
\hline Am-243 & ICP-MS IDA & 0.0093 & 0.0008 & 0.0245 & 0.003 & 0.0418 & 0.007 & 0.0634 & 0.0052 & 0.0510 & 0.0058 & 0.0649 & 0.0054 & 0.0766 & 0.004 \\
\hline $\mathrm{Cm}-244$ & ICP-MS ext & 0.0019 & 0.0004 & 0.0060 & 0.0012 & 0.0151 & 0.003 & 0.0234 & 0.0046 & 0.0221 & 0.0044 & 0.0227 & 0.0046 & 0.0291 & 0.0058 \\
\hline $\mathrm{Cm}-246$ & ICP-MS ext & 0.000018 & 0.000008 & 0.000062 & 0.000024 & 0.000250 & 0.00008 & 0.000570 & 0.00018 & 0.000530 & 0.00018 & 0.000540 & 0.00018 & 0.000730 & 0.00024 \\
\hline Nd-142 & ICP-MS IDA & 0.0026 & 0.0002 & 0.0038 & 0.0006 & 0.0073 & 0.0004 & 0.0104 & 0.0008 & 0.0099 & 0.0008 & 0.0098 & 0.0012 & 0.0072 & 0.0004 \\
\hline Nd-143 & ICP-MS IDA & 0.119 & 0.006 & 0.126 & 0.006 & 0.143 & 0.006 & 0.147 & 0.010 & 0.140 & 0.012 & 0.133 & 0.008 & 0.132 & 0.008 \\
\hline Nd-144 & ICP-MS IDA & 0.191 & 0.008 & 0.238 & 0.012 & 0.307 & 0.014 & 0.392 & 0.024 & 0.382 & 0.034 & 0.370 & 0.018 & 0.373 & 0.020 \\
\hline Nd-145 & ICP-MS IDA & 0.0991 & 0.0048 & 0.1118 & 0.0056 & 0.1386 & 0.0062 & 0.1567 & 0.0098 & 0.1491 & 0.013 & 0.1430 & 0.0072 & 0.1413 & 0.0076 \\
\hline Nd-146 & ICP-MS IDA & 0.1019 & 0.0044 & 0.1263 & 0.0056 & 0.1698 & 0.0068 & 0.2094 & 0.0124 & 0.2041 & 0.0176 & 0.1920 & 0.0094 & 0.1928 & 0.0096 \\
\hline Nd-148 & ICP-MS IDA & 0.0561 & 0.0028 & 0.0660 & 0.0036 & 0.0894 & 0.0038 & 0.0995 & 0.0064 & 0.0998 & 0.009 & 0.0947 & 0.0048 & 0.1026 & 0.0084 \\
\hline Nd-150 & ICP-MS IDA & 0.0991 & 0.0048 & 0.1118 & 0.0056 & 0.1386 & 0.0062 & 0.1567 & 0.0098 & 0.1491 & 0.013 & 0.1430 & 0.0072 & 0.1413 & 0.0076 \\
\hline Cs-133 & ICP-MS ext & 0.162 & 0.026 & 0.183 & 0.028 & 0.228 & 0.036 & 0.237 & 0.038 & 0.219 & 0.034 & 0.221 & 0.034 & 0.219 & 0.034 \\
\hline Cs-134 & $\gamma$-spec & 0.017 & 0.004 & 0.024 & 0.006 & 0.034 & 0.01 & 0.045 & 0.012 & 0.045 & 0.012 & 0.045 & 0.012 & 0.047 & 0.002 \\
\hline Cs-135 & ICP-MS ext & 0.089 & 0.014 & 0.103 & 0.016 & 0.118 & 0.02 & 0.111 & 0.018 & 0.101 & 0.016 & 0.103 & 0.016 & 0.114 & 0.020 \\
\hline Cs-137 & $\gamma$-spec & 0.171 & 0.022 & 0.211 & 0.024 & 0.254 & 0.028 & 0.300 & 0.034 & 0.300 & 0.034 & 0.300 & 0.034 & 0.299 & 0.018 \\
\hline Ce-140 & ICP-MS IDA & 0.165 & 0.008 & 0.212 & 0.008 & 0.270 & 0.01 & 0.324 & 0.014 & 0.301 & 0.014 & 0.300 & 0.020 & 0.320 & 0.018 \\
\hline Ce-142 & ICP-MS IDA & 0.156 & 0.008 & 0.201 & 0.006 & 0.251 & 0.01 & 0.299 & 0.012 & 0.280 & 0.012 & 0.279 & 0.018 & 0.294 & 0.016 \\
\hline Ce-144 & $\gamma$-spec & 0.021 & 0.0058 & 0.0245 & 0.0068 & 0.0288 & 0.008 & 0.0325 & 0.0090 & 0.0328 & 0.0090 & 0.0328 & 0.0090 & 0.033 & 0.004 \\
\hline
\end{tabular}


Table 3.1. Experimental techniques and isotopic concentrations (in $\% g / \mathrm{g}^{238} \mathrm{U}$ ) for $\mathbf{1}^{\text {st }}$ campaign (cont.)

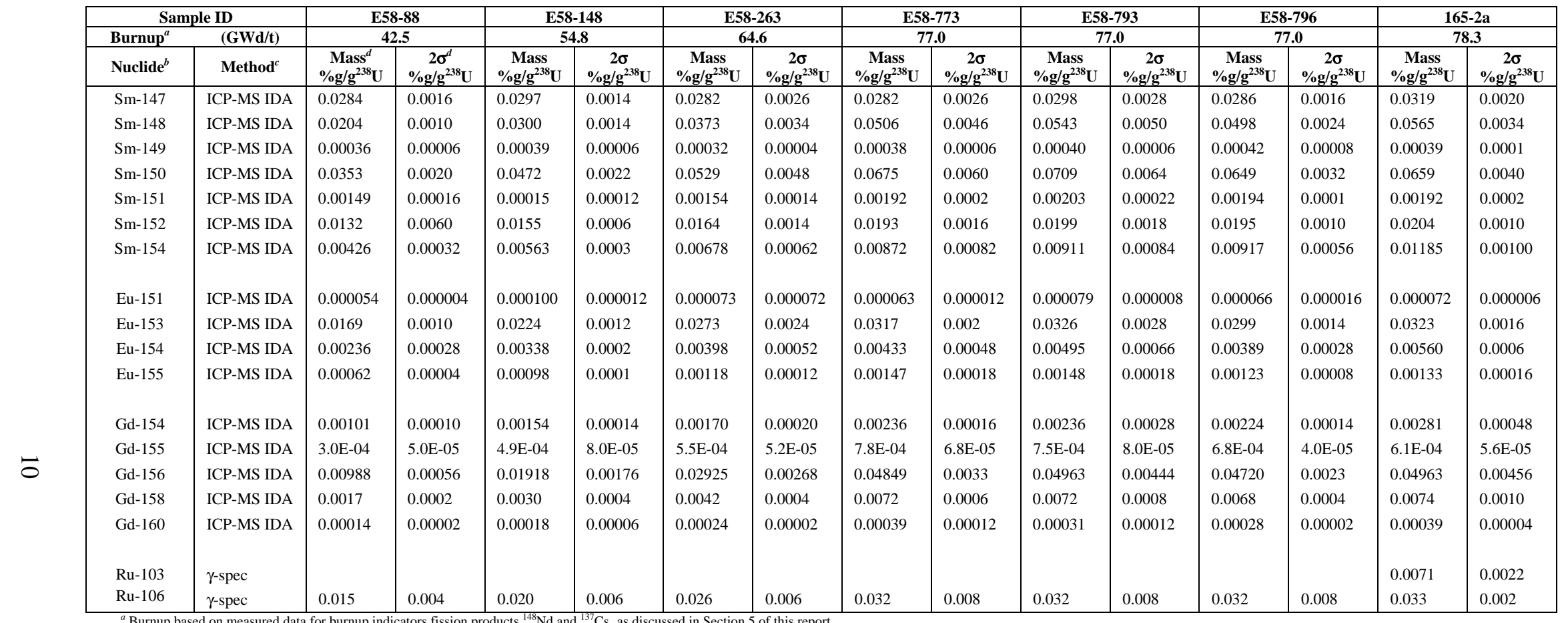

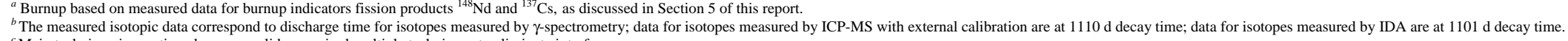

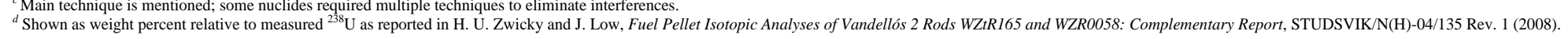


Table 3.2. Experimental techniques and isotopic concentrations (in $\% g / g^{238} U$ ) for $2^{\text {nd }}$ campaign

\begin{tabular}{|c|c|c|c|c|c|c|c|c|c|}
\hline \multicolumn{2}{|c|}{ Sample ID } & \multirow{2}{*}{\multicolumn{2}{|c|}{$\begin{array}{c}\text { E58-88(new) } \\
42.5\end{array}$}} & \multirow{2}{*}{\multicolumn{2}{|c|}{$\begin{array}{c}\text { E58-793(new) } \\
77.0\end{array}$}} & \multirow{2}{*}{\multicolumn{2}{|c|}{$\begin{array}{c}\text { E58-257 } \\
64.6\end{array}$}} & \multirow{2}{*}{\multicolumn{2}{|c|}{$\begin{array}{c}160-800 \\
70.9\end{array}$}} \\
\hline Burnup $^{a}$ & $(\mathrm{GWd} / \mathrm{t})$ & & & & & & & & \\
\hline Nuclide $^{b}$ & Method $^{\mathrm{c}}$ & $\begin{array}{c}\text { Mass }^{d} \\
\% g / g^{238} U\end{array}$ & $\begin{array}{c}2 \sigma^{d} \\
\% g / g^{238} U\end{array}$ & $\begin{array}{c}\text { Mass } \\
\% \mathrm{~g} / \mathrm{g}^{238} \mathrm{U}\end{array}$ & $\begin{array}{c}2 \sigma \\
\% g / g^{238} U\end{array}$ & $\begin{array}{c}\text { Mass } \\
\% \mathrm{~g} / \mathrm{g}^{238} \mathrm{U}\end{array}$ & $\begin{array}{c}2 \sigma \\
\% g / g^{238} U\end{array}$ & $\begin{array}{c}\text { Mass } \\
\% g / g^{238} U \\
\end{array}$ & $\begin{array}{c}2 \sigma \\
\% g / g^{238} U\end{array}$ \\
\hline U-234 & ICP-MS IDA & 0.0247 & 0.0032 & 0.0192 & 0.0028 & 0.0219 & 0.0026 & 0.02 & 0.0024 \\
\hline U-235 & ICP-MS IDA & 1.386 & 0.046 & 0.342 & 0.016 & 0.572 & 0.022 & 0.397 & 0.016 \\
\hline U-236 & ICP-MS IDA & 0.679 & 0.024 & 0.776 & 0.028 & 0.772 & 0.026 & 0.789 & 0.028 \\
\hline $\mathrm{Pu}-238$ & ICP-MS IDA & 0.0277 & 0.0022 & 0.0869 & 0.003 & 0.0688 & 0.0072 & 0.0802 & 0.0026 \\
\hline Pu-239 & ICP-MS IDA & 0.646 & 0.026 & 0.666 & 0.02 & 0.664 & 0.028 & 0.658 & 0.02 \\
\hline $\mathrm{Pu}-240$ & ICP-MS IDA & 0.249 & 0.012 & 0.373 & 0.014 & 0.347 & 0.02 & 0.379 & 0.012 \\
\hline $\mathrm{Pu}-241$ & ICP-MS IDA & 0.117 & 0.008 & 0.169 & 0.006 & 0.162 & 0.016 & 0.169 & 0.006 \\
\hline $\mathrm{Pu}-242$ & ICP-MS IDA & 0.058 & 0.004 & 0.190 & 0.008 & 0.143 & 0.016 & 0.183 & 0.006 \\
\hline Np-237 & ICP-MS ext & 0.063 & 0.01 & 0.113 & 0.018 & 0.099 & 0.016 & 0.112 & 0.018 \\
\hline Am-241 & ICP-MS IDA & 0.075 & 0.004 & 0.093 & 0.004 & 0.064 & 0.006 & 0.065 & 0.004 \\
\hline Am-243 & ICP-MS IDA & 0.012 & 0.004 & 0.053 & 0.002 & 0.037 & 0.004 & 0.050 & 0.004 \\
\hline Cm-244 & ICP-MS ext & 0.0017 & 0.0004 & 0.021 & 0.004 & 0.011 & 0.002 & 0.018 & 0.004 \\
\hline $\mathrm{Cm}-246$ & ICP-MS ext & 2.E-05 & 4.E-06 & 7.E-04 & 2.E+04 & 2.E-04 & 6.E-05 & 5.E-04 & 1.E-04 \\
\hline Nd-142 & ICP-MS IDA & 0.0023 & 0.0002 & 0.0093 & 0.0004 & 0.0061 & 0.0004 & 0.008 & 0.0008 \\
\hline Nd-143 & ICP-MS IDA & 0.114 & 0.004 & 0.140 & 0.004 & 0.134 & 0.006 & 0.132 & 0.004 \\
\hline Nd-144 & ICP-MS IDA & 0.183 & 0.006 & 0.375 & 0.012 & 0.305 & 0.012 & 0.338 & 0.012 \\
\hline Nd-145 & ICP-MS IDA & 0.093 & 0.004 & 0.145 & 0.006 & 0.129 & 0.006 & 0.134 & 0.004 \\
\hline Nd-146 & ICP-MS IDA & 0.096 & 0.002 & 0.194 & 0.006 & 0.157 & 0.004 & 0.175 & 0.006 \\
\hline Nd-148 & ICP-MS IDA & 0.050 & 0.002 & 0.094 & 0.004 & 0.077 & 0.004 & 0.084 & 0.004 \\
\hline Nd-150 & ICP-MS IDA & 0.0243 & 0.0008 & 0.048 & 0.0028 & 0.0393 & 0.0024 & 0.0433 & 0.003 \\
\hline Cs-133 & ICP-MS ext & 0.145 & 0.024 & 0.226 & 0.036 & & & & \\
\hline Cs-134 & $\gamma$-spec & 0.017 & 0.002 & 0.045 & 0.012 & 0.034 & 0.002 & 0.040 & 0.002 \\
\hline Cs-137 & $\gamma$-spec & 0.171 & 0.014 & 0.300 & 0.034 & 0.254 & 0.016 & 0.285 & 0.018 \\
\hline Ce-140 & ICP-MS IDA & 0.173 & 0.006 & 0.314 & 0.014 & 0.255 & 0.018 & 0.304 & 0.022 \\
\hline Ce-142 & ICP-MS IDA & 0.158 & 0.006 & 0.279 & 0.01 & 0.228 & 0.010 & 0.268 & 0.018 \\
\hline Ce-144 & $\gamma$-spec & 0.020 & 0.002 & 0.0328 & 0.009 & 0.029 & 0.004 & & \\
\hline Sm-147 & ICP-MS IDA & 0.033 & 0.004 & 0.032 & 0.002 & 0.034 & 0.002 & 0.035 & 0.002 \\
\hline Sm-148 & ICP-MS IDA & 0.0195 & 0.0018 & 0.0502 & 0.0024 & 0.0388 & 0.0024 & 0.0482 & 0.004 \\
\hline Sm-149 & ICP-MS IDA & 0.00035 & 0.00006 & 0.00036 & 0.00006 & 0.00043 & 0.00004 & 0.00041 & 0.0002 \\
\hline Sm-150 & ICP-MS IDA & 0.0342 & 0.0032 & 0.0670 & 0.0032 & 0.0561 & 0.0034 & 0.0633 & 0.0054 \\
\hline Sm-151 & ICP-MS IDA & 0.00152 & 0.00014 & 0.00189 & 0.00014 & 0.00176 & 0.00016 & 0.00183 & 0.00018 \\
\hline Sm-152 & ICP-MS IDA & 0.0129 & 0.0004 & 0.0189 & 0.0008 & 0.0173 & 0.0080 & 0.0191 & 0.0140 \\
\hline Sm-154 & ICP-MS IDA & 0.00466 & 0.00058 & 0.01105 & 0.00062 & 0.00787 & 0.00206 & 0.01029 & 0.00086 \\
\hline Eu-151 & ICP-MS IDA & 0.000064 & 0.000014 & 0.000072 & 0.000036 & 0.000068 & 0.000020 & 0.000085 & 0.000008 \\
\hline Eu-153 & ICP-MS IDA & 0.0137 & 0.0012 & 0.0244 & 0.0008 & 0.0220 & 0.0020 & 0.0247 & 0.0020 \\
\hline Eu-154 & ICP-MS IDA & 0.00172 & 0.00016 & 0.00350 & 0.00016 & 0.00307 & 0.00028 & 0.00346 & 0.00030 \\
\hline Eu-155 & ICP-MS IDA & 0.00044 & 0.00010 & 0.00092 & 0.00004 & 0.00076 & 0.00010 & 0.00090 & 0.00008 \\
\hline
\end{tabular}


Table 3.2. Experimental techniques and isotopic concentrations (in $\% g / g^{238} U$ ) for $2^{\text {nd }}$ campaign (cont.)

\begin{tabular}{|c|c|c|c|c|c|c|c|c|c|}
\hline \multicolumn{2}{|c|}{ Sample ID } & \multirow{2}{*}{\multicolumn{2}{|c|}{$\begin{array}{c}\text { E58-88(new) } \\
42.5\end{array}$}} & \multirow{2}{*}{\multicolumn{2}{|c|}{$\begin{array}{c}\text { E58-793(new) } \\
77.0\end{array}$}} & \multirow{2}{*}{\multicolumn{2}{|c|}{\begin{tabular}{|c|} 
E58-257 \\
64.6
\end{tabular}}} & \multirow{2}{*}{\multicolumn{2}{|c|}{\begin{tabular}{c|}
$160-800$ \\
70.9 \\
\end{tabular}}} \\
\hline Burnup $^{a}$ & $(G W d / t)$ & & & & & & & & \\
\hline Nuclide $^{b}$ & Method $^{c}$ & $\begin{array}{c}\text { Mass }^{d} \\
\% \mathrm{~g} / \mathrm{g}^{238} \mathrm{U}\end{array}$ & $\begin{array}{c}2 \sigma^{d} \\
\% \mathrm{~g} / \mathrm{g}^{238} \mathrm{U}\end{array}$ & $\begin{array}{c}\text { Mass } \\
\% \mathrm{~g} / \mathrm{g}^{238} \mathrm{U}\end{array}$ & $\begin{array}{c}2 \sigma \\
\% \mathrm{~g} / \mathrm{g}^{238} \mathrm{U}\end{array}$ & $\begin{array}{c}\text { Mass } \\
\% \mathrm{~g} / \mathrm{g}^{238} \mathrm{U}\end{array}$ & $\begin{array}{c}2 \sigma \\
\% \mathrm{~g} / \mathrm{g}^{238} \mathrm{U}\end{array}$ & $\begin{array}{c}\text { Mass } \\
\% \mathrm{~g} / \mathrm{g}^{238} \mathrm{U}\end{array}$ & $\begin{array}{c}2 \sigma \\
\% \mathrm{~g} / \mathrm{g}^{238} \mathrm{U}\end{array}$ \\
\hline Gd-154 & ICP-MS IDA & 0.00141 & 0.00004 & 0.00313 & 0.00022 & 0.00262 & 0.00018 & 0.00318 & 0.00026 \\
\hline Gd-155 & ICP-MS IDA & 0.00049 & 0.00009 & 0.00083 & 0.000112 & 0.00093 & 0.00008 & 0.0022 & 0.000072 \\
\hline Gd-156 & ICP-MS IDA & 0.0095 & 0.0004 & 0.0467 & 0.0020 & 0.0293 & 0.0012 & 0.0434 & 0.0014 \\
\hline Gd-158 & ICP-MS IDA & 0.0017 & 0.00008 & 0.00692 & 0.00032 & 0.00433 & 0.00022 & 0.00632 & 0.00038 \\
\hline Gd-160 & ICP-MS IDA & 0.00014 & 0.00002 & 0.00037 & 0.00002 & $<0.0004$ & & 0.00033 & 0.00002 \\
\hline Rh-103 & ICP-MS ext & & & & & 0.0448 & 0.0080 & 0.0818 & 0.0160 \\
\hline Ru-106 & $\gamma$-spec & 0.015 & 0.002 & 0.032 & 0.008 & 0.026 & 0.002 & & \\
\hline La-139 & ICP-MS ext & 0.161 & 0.026 & 0.286 & 0.046 & 0.23 & 0.036 & 0.259 & 0.042 \\
\hline Tc-99 & ICP-MS ext & 0.103 & 0.016 & 0.115 & 0.018 & 0.134 & 0.022 & 0.163 & 0.026 \\
\hline Mo-95 & ICP-MS IDA & & & & & 0.051 & 0.004 & 0.116 & 0.032 \\
\hline Mo-97 & ICP-MS IDA & & & & & 0.056 & 0.004 & 0.134 & 0.008 \\
\hline Mo-98 & ICP-MS IDA & & & & & 0.072 & 0.006 & 0.159 & 0.044 \\
\hline Mo-100 & ICP-MS IDA & & & & & 0.068 & 0.008 & 0.172 & 0.05 \\
\hline
\end{tabular}

Table 3.3. Half-lives of isotopes used in data adjustment

\begin{tabular}{|l|c|l|c|}
\hline Nuclide & $\begin{array}{l}\text { Half-life } \\
\text { (years) }\end{array}$ & Nuclide & $\begin{array}{l}\text { Half-life } \\
\text { (years) }\end{array}$ \\
\hline Am-241 & 432.54 & Eu-154 & 8.592 \\
Pu-241 & 14.35 & Eu-155 & 4.68 \\
Ce-144 & 0.78 & Pu-238 & 87.71 \\
Cm-244 & 18.1 & Ru-106 & 1.017 \\
Cs-137 & 30 & Sm-151 & 90 \\
\hline
\end{tabular}


Table 3.4. Isotopic concentrations - combined data (in $\% g / \mathrm{g}^{238} \mathrm{U}$ )

\begin{tabular}{|c|c|c|c|c|c|c|c|c|c|c|c|c|c|c|c|c|c|c|}
\hline Sample ID & \multirow{2}{*}{\multicolumn{3}{|c|}{$\begin{array}{c}\text { E58-88 } \\
42.5\end{array}$}} & \multirow{2}{*}{\multicolumn{3}{|c|}{$\begin{array}{c}\text { E58-148 } \\
54.8\end{array}$}} & \multirow{2}{*}{\multicolumn{3}{|c|}{$\begin{array}{c}\text { E58-260 } \\
64.6\end{array}$}} & \multirow{2}{*}{\multicolumn{3}{|c|}{$\frac{\text { E58-700 }}{77.0}$}} & \multirow{2}{*}{\multicolumn{3}{|c|}{$\begin{array}{c}165-2 a \\
78.3\end{array}$}} & \multirow{2}{*}{\multicolumn{3}{|c|}{$\frac{160-800}{709}$}} \\
\hline Burnup ${ }^{a}$ & & & & & & & & & & & & & & & & & & \\
\hline Nuclide $^{b}$ & 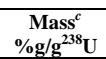 & $\begin{array}{c}\text { Uncertd } \\
\% \mathrm{~g} / \mathrm{g}^{238} \mathrm{U}\end{array}$ & $\begin{array}{c}\text { Uncerte }^{{ }^{2}} \\
(\%)\end{array}$ & $\begin{array}{c}\text { Mass } \\
\% \mathrm{~g} / \mathrm{g}^{238} \mathrm{U}\end{array}$ & $\begin{array}{c}\text { Uncert } \\
\% \mathrm{~g} / \mathrm{g}^{238} \mathrm{U}\end{array}$ & $\begin{array}{c}\text { Uncert } \\
(\%)\end{array}$ & $\underset{\substack{\text { Mass } \\
\% / \mathrm{g}^{238} \mathrm{U}}}{ }$ & $\begin{array}{c}\text { Uncert } \\
\% \mathrm{~g} / \mathrm{g}^{238} \mathrm{U}\end{array}$ & $\begin{array}{c}\text { Uncert } \\
(\%)\end{array}$ & $\begin{array}{c}\text { Mass } \\
\% \mathrm{~g} / \mathrm{g}^{238} \mathrm{U}\end{array}$ & $\begin{array}{c}\text { Uncert } \\
\% \mathrm{~g} / \mathrm{g}^{238} \mathrm{U}\end{array}$ & $\begin{array}{c}\text { Uncert } \\
(\%)\end{array}$ & $\begin{array}{c}\text { Mass } \\
\% \mathrm{~g} / \mathrm{g}^{238} \mathrm{U}\end{array}$ & $\begin{array}{c}\text { Uncert } \\
\% \mathrm{~g} / \mathrm{g}^{238} \mathrm{U}\end{array}$ & $\begin{array}{c}\text { Uncert } \\
(\%)\end{array}$ & $\begin{array}{c}\text { Mass } \\
\% \mathrm{~g} / \mathrm{g}^{238} \mathrm{U}\end{array}$ & $\begin{array}{c}\text { Uncert } \\
\% \mathrm{~g} / \mathrm{g}^{238} \mathrm{U}\end{array}$ & $\begin{array}{c}\text { Uncert } \\
(\%)\end{array}$ \\
\hline U-234 & 2.453E-02 & $4.323 \mathrm{E}-03$ & 17.6 & $2.318 \mathrm{E}-02$ & $3.381 \mathrm{E}-03$ & 14.6 & 1.612E-02 & $6.478 \mathrm{E}-03$ & 40.2 & $1.446 \mathrm{E}-02$ & $2.449 \mathrm{E}-03$ & 16.9 & $1.400 \mathrm{E}-02$ & $3.838 \mathrm{E}-03$ & 27.4 & $1.770 \mathrm{E}-02$ & $2.139 \mathrm{E}-03$ & 12.1 \\
\hline U-235 & $1.328 \mathrm{E}+00$ & $1.484 \mathrm{E}-01$ & 11.2 & $9.211 \mathrm{E}-01$ & $6.324 \mathrm{E}-02$ & 6.9 & $5.251 \mathrm{E}-01$ & $7.138 \mathrm{E}-02$ & 13.6 & $3.192 \mathrm{E}-01$ & 2.023E-02 & 6.3 & $2.939 \mathrm{E}-01$ & 2.690E-02 & 9.2 & $3.970 \mathrm{E}-01$ & $1.568 \mathrm{E}-02$ & 3.9 \\
\hline U-236 & $5.676 \mathrm{E}-01$ & $5.606 \mathrm{E}-02$ & 9.9 & $6.868 \mathrm{E}-01$ & $5.003 \mathrm{E}-02$ & 7.3 & $6.773 \mathrm{E}-01$ & $8.950 \mathrm{E}-02$ & 13.2 & $6.629 \mathrm{E}-01$ & $3.541 \mathrm{E}-02$ & 5.3 & $6.809 \mathrm{E}-01$ & $5.022 \mathrm{E}-02$ & 7.4 & 7.891E-01 & $2.752 \mathrm{E}-02$ & 3.5 \\
\hline Pu-238 & $2.826 \mathrm{E}-02$ & $1.469 \mathrm{E}-03$ & 5.2 & 4.016E-02 & $5.339 \mathrm{E}-03$ & 13.3 & $6.774 \mathrm{E}-02$ & $5.111 \mathrm{E}-03$ & 7.5 & $8.928 \mathrm{E}-02$ & $2.697 \mathrm{E}-03$ & 3.0 & $9.711 \mathrm{E}-02$ & 9.504E-03 & 9.8 & $8.257 \mathrm{E}-02$ & $2.598 \mathrm{E}-03$ & 3.1 \\
\hline Pu-239 & $6.481 \mathrm{E}-01$ & $1.969 \mathrm{E}-02$ & 3.0 & 6.419E-01 & 4.441E-02 & 6.9 & $6.599 \mathrm{E}-01$ & 2.617E-02 & 4.0 & $6.715 \mathrm{E}-01$ & $1.672 \mathrm{E}-02$ & 2.5 & 7.410E-01 & 4.457E-02 & 6.0 & $6.580 \mathrm{E}-01$ & $1.902 \mathrm{E}-02$ & 2.9 \\
\hline Pu-240 & $2.494 \mathrm{E}-01$ & $8.354 \mathrm{E}-03$ & 3.4 & $2.927 \mathrm{E}-01$ & $2.049 \mathrm{E}-02$ & 7.0 & $3.402 \mathrm{E}-01$ & $1.695 \mathrm{E}-02$ & 5.0 & $3.737 \mathrm{E}-01$ & $1.050 \mathrm{E}-02$ & 2.8 & $4.043 \mathrm{E}-01$ & $2.591 \mathrm{E}-02$ & 6.4 & $3.762 \mathrm{E}-01$ & $1.094 \mathrm{E}-02$ & 2.9 \\
\hline Pu-241 & $1.387 \mathrm{E}-01$ & $5.427 \mathrm{E}-03$ & 3.9 & $1.603 \mathrm{E}-01$ & $1.148 \mathrm{E}-02$ & 7.2 & $1.869 \mathrm{E}-01$ & $1.305 \mathrm{E}-02$ & 7.0 & $2.005 \mathrm{E}-01$ & $5.969 \mathrm{E}-03$ & 3.0 & $2.211 \mathrm{E}-01$ & $1.424 \mathrm{E}-02$ & 6.4 & $2.008 \mathrm{E}-01$ & $6.125 \mathrm{E}-03$ & 3.1 \\
\hline Pu-242 & $5.776 \mathrm{E}-02$ & $2.388 \mathrm{E}-03$ & 4.1 & $9.201 \mathrm{E}-02$ & 6.622E-03 & 7.2 & $1.396 \mathrm{E}-01$ & $1.026 \mathrm{E}-02$ & 7.3 & $1.888 \mathrm{E}-01$ & $6.114 \mathrm{E}-03$ & 3.2 & $2.095 \mathrm{E}-01$ & $1.295 \mathrm{E}-02$ & 6.2 & $1.831 \mathrm{E}-01$ & $5.357 \mathrm{E}-03$ & 2.9 \\
\hline Np-237 & $6.676 \mathrm{E}-02$ & $7.575 \mathrm{E}-03$ & 11.3 & $9.987 \mathrm{E}-02$ & $1.598 \mathrm{E}-02$ & 16.0 & $1.100 \mathrm{E}-01$ & $1.256 \mathrm{E}-02$ & 11.4 & $1.194 \mathrm{E}-01$ & $9.562 \mathrm{E}-03$ & 8.0 & $1.404 \mathrm{E}-01$ & $2.246 \mathrm{E}-02$ & 16.0 & $1.121 \mathrm{E}-01$ & $1.794 \mathrm{E}-02$ & 16.0 \\
\hline Am-241 & 2.603E-02 & $1.934 \mathrm{E}-03$ & 7.4 & $2.880 \mathrm{E}-02$ & $1.885 \mathrm{E}-03$ & 6.5 & $3.297 \mathrm{E}-02$ & $2.149 \mathrm{E}-03$ & 6.5 & $3.296 \mathrm{E}-02$ & $1.369 \mathrm{E}-03$ & 4.2 & $3.707 \mathrm{E}-02$ & $1.921 \mathrm{E}-03$ & 5.2 & $3.251 \mathrm{E}-02$ & $1.789 \mathrm{E}-03$ & 5.5 \\
\hline Am-243 & $9.493 \mathrm{E}-03$ & 7.679E-04 & 8.1 & 2.453E-02 & $2.935 \mathrm{E}-03$ & 12.0 & $3.733 \mathrm{E}-02$ & $2.767 \mathrm{E}-03$ & 7.4 & 5.566E-02 & $3.735 \mathrm{E}-03$ & 6.7 & 7.660E-02 & 4.014E-03 & 5.2 & $4.982 \mathrm{E}-02$ & 3.923E-03 & 7.9 \\
\hline Cm-244 & $1.908 \mathrm{E}-03$ & 2.699E-04 & 14.1 & $5.961 \mathrm{E}-03$ & $1.192 \mathrm{E}-03$ & 20.0 & $1.323 \mathrm{E}-02$ & $1.883 \mathrm{E}-03$ & 14.2 & $2.300 \mathrm{E}-02$ & $2.301 \mathrm{E}-03$ & 10.0 & $2.907 \mathrm{E}-02$ & $5.814 \mathrm{E}-03$ & 20.0 & $2.091 \mathrm{E}-02$ & $4.182 \mathrm{E}-03$ & 20.0 \\
\hline Cm-246 & $1.847 \mathrm{E}-05$ & $3.918 \mathrm{E}-06$ & 21.2 & $6.226 \mathrm{E}-05$ & $1.868 \mathrm{E}-05$ & 30.0 & $2.416 \mathrm{E}-04$ & $5.129 \mathrm{E}-05$ & 21.2 & $5.750 \mathrm{E}-04$ & $8.691 \mathrm{E}-05$ & 15.1 & $7.267 \mathrm{E}-04$ & $2.180 \mathrm{E}-04$ & 30.0 & $5.488 \mathrm{E}-04$ & $1.646 \mathrm{E}-04$ & 30.0 \\
\hline Nd-142 & $2.310 \mathrm{E}-03$ & $1.024 \mathrm{E}-04$ & 4.4 & 3.834E-03 & $5.508 \mathrm{E}-04$ & 14.4 & $6.144 \mathrm{E}-03$ & 4.212E-04 & 6.9 & $9.510 \mathrm{E}-03$ & $3.090 \mathrm{E}-04$ & 3.2 & & & & $8.038 \mathrm{E}-03$ & $7.118 \mathrm{E}-04$ & 8.9 \\
\hline $\mathrm{Nd}-143$ & $1.145 \mathrm{E}-01$ & 4.083E-03 & 3.6 & $1.259 \mathrm{E}-01$ & $6.582 \mathrm{E}-03$ & 5.2 & $1.343 \mathrm{E}-01$ & $5.954 \mathrm{E}-03$ & 4.4 & $1.395 \mathrm{E}-01$ & $3.690 \mathrm{E}-03$ & 2.6 & $1.318 \mathrm{E}-01$ & 7.078E-03 & 5.4 & $1.321 \mathrm{E}-01$ & $4.271 \mathrm{E}-03$ & 3.2 \\
\hline $\mathrm{Nd}-145$ & $9.289 \mathrm{E}-02$ & $3.972 \mathrm{E}-03$ & 4.3 & $1.118 \mathrm{E}-01$ & $5.658 \mathrm{E}-03$ & 5.1 & $1.288 \mathrm{E}-01$ & $5.616 \mathrm{E}-03$ & 4.4 & $1.468 \mathrm{E}-01$ & $4.047 \mathrm{E}-03$ & 2.8 & $1.413 \mathrm{E}-01$ & 7.653E-03 & 5.4 & $1.339 \mathrm{E}-01$ & $4.787 \mathrm{E}-03$ & 3.6 \\
\hline Nd-146 & $9.552 \mathrm{E}-02$ & $2.777 \mathrm{E}-03$ & 2.9 & $1.263 \mathrm{E}-01$ & $5.574 \mathrm{E}-03$ & 4.4 & $1.567 \mathrm{E}-01$ & $4.573 \mathrm{E}-03$ & 2.9 & $1.961 \mathrm{E}-01$ & $4.355 \mathrm{E}-03$ & 2.2 & $1.928 \mathrm{E}-01$ & $9.642 \mathrm{E}-03$ & 5.0 & $1.749 \mathrm{E}-01$ & $5.182 \mathrm{E}-03$ & 3.0 \\
\hline Nd-148 & $5.048 \mathrm{E}-02$ & $1.944 \mathrm{E}-03$ & 3.9 & $6.604 \mathrm{E}-02$ & $3.526 \mathrm{E}-03$ & 5.3 & 7.670E-02 & $3.391 \mathrm{E}-03$ & 4.4 & $9.576 \mathrm{E}-02$ & $2.502 \mathrm{E}-03$ & 2.6 & $1.026 \mathrm{E}-01$ & 8.438E-03 & 8.2 & $8.440 \mathrm{E}-02$ & $4.846 \mathrm{E}-03$ & 5.7 \\
\hline Nd-150 & 2.432E-02 & $8.933 \mathrm{E}-04$ & 3.7 & 2.997E-02 & $1.700 \mathrm{E}-03$ & 5.7 & $3.933 \mathrm{E}-02$ & $2.383 \mathrm{E}-03$ & 6.1 & $4.511 \mathrm{E}-02$ & $1.430 \mathrm{E}-03$ & 3.2 & $5.266 \mathrm{E}-02$ & 3.235E-03 & 6.1 & $4.327 \mathrm{E}-02$ & $2.915 \mathrm{E}-03$ & 6.7 \\
\hline Cs-133 & $1.526 \mathrm{E}-01$ & $1.729 \mathrm{E}-02$ & 11.3 & $1.826 \mathrm{E}-01$ & $2.922 \mathrm{E}-02$ & 16.0 & $2.277 \mathrm{E}-01$ & $3.644 \mathrm{E}-02$ & 16.0 & $2.254 \mathrm{E}-01$ & $1.804 \mathrm{E}-02$ & 8.0 & $2.191 \mathrm{E}-01$ & $3.506 \mathrm{E}-02$ & 16.0 & & & \\
\hline Cs-134 & $1.680 \mathrm{E}-02$ & $1.990 \mathrm{E}-03$ & 11.8 & $2.438 \mathrm{E}-02$ & $1.999 \mathrm{E}-03$ & 8.2 & $3.410 \mathrm{E}-02$ & $2.342 \mathrm{E}-03$ & 6.9 & 4.484E-02 & $2.067 \mathrm{E}-03$ & 4.6 & $4.702 \mathrm{E}-02$ & 3.283E-03 & 7.0 & $3.974 \mathrm{E}-02$ & $2.641 \mathrm{E}-03$ & 6.6 \\
\hline Cs-135 & $8.907 \mathrm{E}-02$ & $1.425 \mathrm{E}-02$ & 16.0 & 1.035E-01 & $1.656 \mathrm{E}-02$ & 16.0 & $1.179 \mathrm{E}-01$ & $1.886 \mathrm{E}-02$ & 16.0 & $1.050 \mathrm{E}-01$ & $9.710 \mathrm{E}-03$ & 9.2 & $1.141 \mathrm{E}-01$ & $1.826 \mathrm{E}-02$ & 16.0 & & & \\
\hline Cs-137 & $1.708 \mathrm{E}-01$ & $1.347 \mathrm{E}-02$ & 7.9 & $2.102 \mathrm{E}-01$ & $1.430 \mathrm{E}-02$ & 6.8 & $2.538 \mathrm{E}-01$ & $1.572 \mathrm{E}-02$ & 6.2 & 2.990E-01 & $1.323 \mathrm{E}-02$ & 4.4 & $3.094 \mathrm{E}-01$ & $2.066 \mathrm{E}-02$ & 6.7 & $2.850 \mathrm{E}-01$ & $1.752 \mathrm{E}-02$ & 6.1 \\
\hline Ce-140 & $1.698 \mathrm{E}-01$ & $5.096 \mathrm{E}-03$ & 3.0 & $2.121 \mathrm{E}-01$ & $7.684 \mathrm{E}-03$ & 3.6 & $2.659 \mathrm{E}-01$ & $9.217 \mathrm{E}-03$ & 3.5 & $3.117 \mathrm{E}-01$ & 7.199E-03 & 2.3 & $3.201 \mathrm{E}-01$ & $1.850 \mathrm{E}-02$ & 5.8 & $3.037 \mathrm{E}-01$ & $2.101 \mathrm{E}-02$ & 6.9 \\
\hline Ce-142 & $1.572 \mathrm{E}-01$ & 4.355E-03 & 2.8 & 2.012E-01 & $6.099 \mathrm{E}-03$ & 3.0 & 2.406E-01 & $1.480 \mathrm{E}-02$ & 6.2 & $2.852 \mathrm{E}-01$ & $6.259 \mathrm{E}-03$ & 2.2 & $2.938 \mathrm{E}-01$ & $1.691 \mathrm{E}-02$ & 5.8 & $2.677 \mathrm{E}-01$ & $1.846 \mathrm{E}-02$ & 6.9 \\
\hline Ce-144 & $2.040 \mathrm{E}-02$ & $2.950 \mathrm{E}-03$ & 14.5 & $2.445 \mathrm{E}-02$ & $3.166 \mathrm{E}-03$ & 13.0 & $2.874 \mathrm{E}-02$ & $3.775 \mathrm{E}-03$ & 13.1 & $3.260 \mathrm{E}-02$ & $2.999 \mathrm{E}-03$ & 9.2 & $3.440 \mathrm{E}-02$ & $1.340 \mathrm{E}-02$ & 39.0 & & & \\
\hline
\end{tabular}


Table 3.4. Isotopic concentrations - combined data (in $\left.\% \mathrm{~g} / \mathrm{g}^{238} \mathrm{U}\right)$ (cont.)

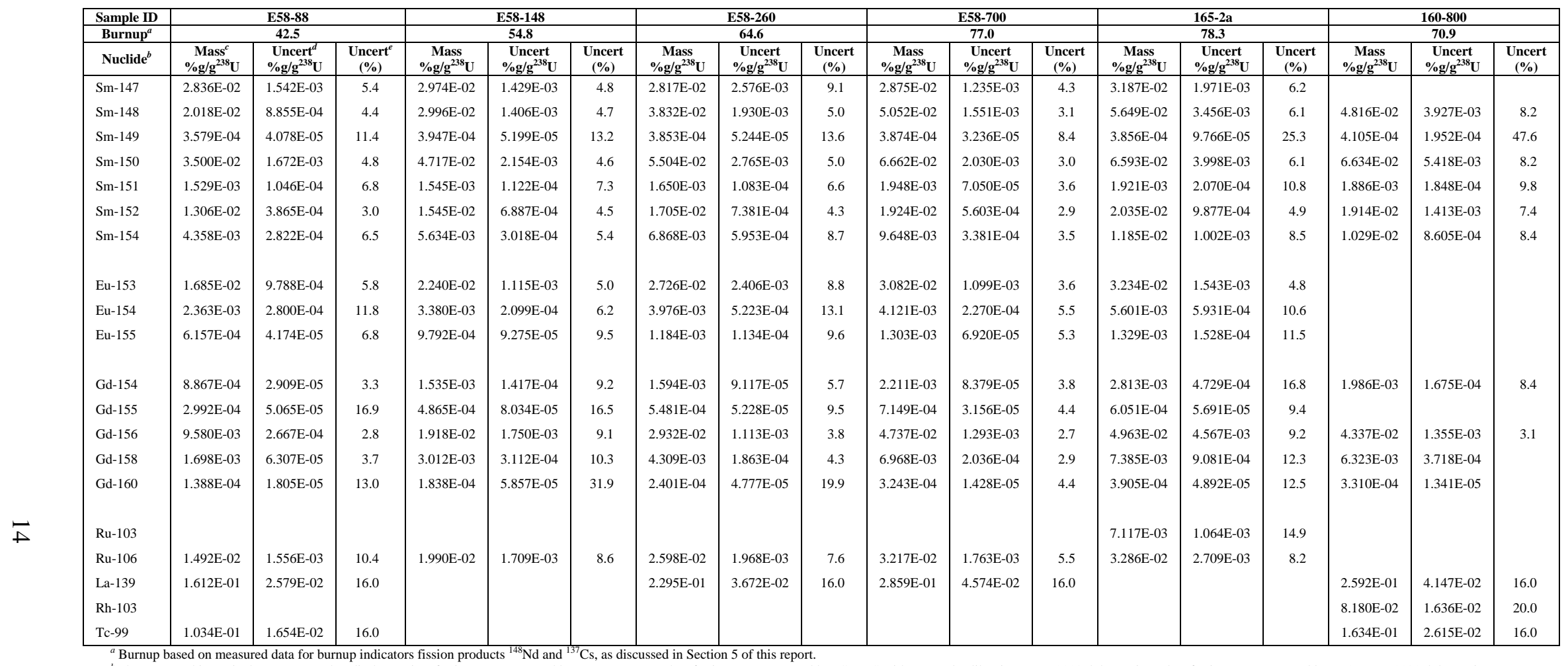

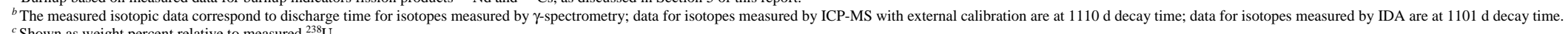
${ }_{d}{ }^{d}$ Measurement uncertainty at $95 \%$ confidunce

${ }^{e}$ Relative measurement uncertainty. 
Table 3.5. Isotopic concentrations - combined data (in $\mathbf{g} / g \mathbf{U}_{\text {initial }}$ )

\begin{tabular}{|c|c|c|c|c|c|c|c|c|c|c|c|c|c|c|c|c|c|c|}
\hline \multirow{3}{*}{$\begin{array}{l}\text { Sample ID } \\
\text { Burnup }^{a} \\
\text { Nuclide }^{\mathrm{b}}\end{array}$} & \multirow{2}{*}{\multicolumn{3}{|c|}{$\begin{array}{l}\text { E58-88 } \\
42.5\end{array}$}} & \multirow{2}{*}{\multicolumn{3}{|c|}{ E58-148 }} & \multirow{2}{*}{\multicolumn{3}{|c|}{$\frac{558-260}{64.6}$}} & \multirow{2}{*}{\multicolumn{3}{|c|}{ E58-700 }} & \multirow{2}{*}{\multicolumn{3}{|c|}{$\frac{165-2 a}{78.3}$}} & \multirow{2}{*}{\multicolumn{3}{|c|}{$\frac{160-800}{70.9}$}} \\
\hline & & & & & & & & & & & & & & & & & & \\
\hline & $\begin{array}{c}\text { Mass }{ }^{c} \\
\% \mathrm{~g}^{2 \mathbf{g}^{38} \mathrm{U}} \mathrm{U}\end{array}$ & $\begin{array}{l}\text { Uncertd }^{d} \\
\% \mathrm{~g} / \mathrm{g}^{238} \mathrm{U}\end{array}$ & $\begin{array}{c}\text { Uncerte }^{\text {Un }} \\
(\%)\end{array}$ & $\begin{array}{c}\text { Mass } \\
\% \mathrm{~g} / \mathrm{g}^{238} \mathrm{U}\end{array}$ & $\begin{array}{c}\text { Uncert } \\
\% \mathrm{~g} / \mathrm{g}^{238} \mathrm{U}\end{array}$ & $\begin{array}{c}\text { Uncert } \\
(\%)\end{array}$ & $\begin{array}{c}\text { Mass } \\
\% \mathrm{~g} / \mathrm{g}^{238} \mathrm{U}\end{array}$ & $\begin{array}{c}\text { Uncert } \\
\% \mathrm{~g} / \mathrm{g}^{238} \mathrm{U}\end{array}$ & $\begin{array}{c}\text { Uncert } \\
(\%)\end{array}$ & $\begin{array}{c}\text { Mass } \\
\% \mathrm{~g} / \mathrm{g}^{238} \mathrm{U} \\
\end{array}$ & $\begin{array}{c}\text { Uncert } \\
\% \mathrm{~g} / \mathrm{g}^{238} \mathrm{U}\end{array}$ & $\begin{array}{c}\text { Uncert } \\
(\%)\end{array}$ & $\begin{array}{c}\text { Mass } \\
\% \mathrm{~g} / \mathrm{g}^{238} \mathrm{U}\end{array}$ & $\begin{array}{c}\text { Uncert } \\
\% \mathrm{~g} / \mathrm{g}^{238} \mathrm{U}\end{array}$ & $\begin{array}{l}\text { Uncert } \\
(\%)\end{array}$ & $\begin{array}{c}\text { Mass } \\
\% \mathrm{~g} / \mathrm{g}^{238} \mathrm{U}\end{array}$ & $\begin{array}{c}\text { Uncert } \\
\% \mathrm{~g} / \mathrm{g}^{238} \mathrm{U}\end{array}$ & $\begin{array}{c}\text { Uncert } \\
(\%)\end{array}$ \\
\hline U-234 & $2.276 \mathrm{E}-04$ & 4.012E-05 & 17.6 & $2.528 \mathrm{E}+00$ & $3.687 \mathrm{E}-01$ & 14.6 & $1.468 \mathrm{E}-04$ & $5.899 \mathrm{E}-05$ & 40.2 & $1.297 \mathrm{E}-04$ & $2.196 \mathrm{E}-05$ & 16.9 & $1.246 \mathrm{E}-04$ & $3.417 \mathrm{E}-05$ & 27.4 & & & \\
\hline U-235 & $1.232 \mathrm{E}-02$ & $1.377 \mathrm{E}-03$ & 11.2 & $1.004 \mathrm{E}+02$ & $6.897 \mathrm{E}+00$ & 6.9 & $4.782 \mathrm{E}-03$ & $6.500 \mathrm{E}-04$ & 13.6 & $2.863 \mathrm{E}-03$ & $1.814 \mathrm{E}-04$ & 6.3 & 2.617E-03 & 2.395E-04 & 9.2 & & & \\
\hline U-236 & $5.267 \mathrm{E}-03$ & 5.203E-04 & 9.9 & 7.490E+01 & $5.456 \mathrm{E}+00$ & 7.3 & $6.168 \mathrm{E}-03$ & $8.150 \mathrm{E}-04$ & 13.2 & $5.945 \mathrm{E}-03$ & $3.175 \mathrm{E}-04$ & 5.3 & $6.062 \mathrm{E}-03$ & 4.471E-04 & 7.4 & & & \\
\hline Pu-238 & 2.623E-04 & 1.363E-05 & 5.2 & $4.379 \mathrm{E}+00$ & 5.823E-01 & 13.3 & $6.168 \mathrm{E}-04$ & 4.654E-05 & 7.5 & $8.007 \mathrm{E}-04$ & $2.419 \mathrm{E}-05$ & 3.0 & $8.646 \mathrm{E}-04$ & $8.461 \mathrm{E}-05$ & 9.8 & $7.464 \mathrm{E}-04$ & $2.348 \mathrm{E}-05$ & 3.1 \\
\hline Pu-239 & $6.014 \mathrm{E}-03$ & $1.828 \mathrm{E}-04$ & 3.0 & $7.000 \mathrm{E}+01$ & $4.843 \mathrm{E}+00$ & 6.9 & $6.009 \mathrm{E}-03$ & $2.383 \mathrm{E}-04$ & 4.0 & $6.022 \mathrm{E}-03$ & $1.499 \mathrm{E}-04$ & 2.5 & $6.597 \mathrm{E}-03$ & $3.968 \mathrm{E}-04$ & 6.0 & $5.948 \mathrm{E}-03$ & $1.719 \mathrm{E}-04$ & 2.9 \\
\hline Pu-240 & $2.314 \mathrm{E}-03$ & 7.753E-05 & 3.4 & $3.192 \mathrm{E}+01$ & $2.235 \mathrm{E}+00$ & 7.0 & $3.098 \mathrm{E}-03$ & $1.544 \mathrm{E}-04$ & 5.0 & $3.351 \mathrm{E}-03$ & $9.416 \mathrm{E}-05$ & 2.8 & 3.599E-03 & 2.306E-04 & 6.4 & $3.400 \mathrm{E}-03$ & $9.886 \mathrm{E}-05$ & 2.9 \\
\hline Pu-241 & $1.287 \mathrm{E}-03$ & $5.036 \mathrm{E}-05$ & 3.9 & $1.748 \mathrm{E}+01$ & $1.252 \mathrm{E}+00$ & 7.2 & $1.702 \mathrm{E}-03$ & $1.189 \mathrm{E}-04$ & 7.0 & $1.798 \mathrm{E}-03$ & $5.353 \mathrm{E}-05$ & 3.0 & $1.968 \mathrm{E}-03$ & $1.268 \mathrm{E}-04$ & 6.4 & $1.815 \mathrm{E}-03$ & $5.536 \mathrm{E}-05$ & 3.1 \\
\hline Pu-242 & $2.276 \mathrm{E}-04$ & 4.012E-05 & 17.6 & $2.528 \mathrm{E}+00$ & 3.687E-01 & 14.6 & $1.468 \mathrm{E}-04$ & $5.899 \mathrm{E}-05$ & 40.2 & $1.297 \mathrm{E}-04$ & $2.196 \mathrm{E}-05$ & 16.9 & $1.246 \mathrm{E}-04$ & $3.417 \mathrm{E}-05$ & 27.4 & & & \\
\hline Np-237 & $6.195 \mathrm{E}-04$ & 7.029E-05 & 11.3 & $1.089 \mathrm{E}+01$ & $1.743 \mathrm{E}+00$ & 16.0 & $1.001 \mathrm{E}-03$ & $1.144 \mathrm{E}-04$ & 11.4 & $1.071 \mathrm{E}-03$ & $8.576 \mathrm{E}-05$ & 8.0 & $1.250 \mathrm{E}-03$ & $1.999 \mathrm{E}-04$ & 16.0 & $1.014 \mathrm{E}-03$ & 1.622E-04 & 16.0 \\
\hline Am-241 & $2.415 \mathrm{E}-04$ & $1.795 \mathrm{E}-05$ & 7.4 & $3.141 \mathrm{E}+00$ & $2.056 \mathrm{E}-01$ & 6.5 & $3.003 \mathrm{E}-04$ & $1.957 \mathrm{E}-05$ & 6.5 & $2.956 \mathrm{E}-04$ & $1.228 \mathrm{E}-05$ & 4.2 & 3.300E-04 & $1.710 \mathrm{E}-05$ & 5.2 & $2.938 \mathrm{E}-04$ & $1.617 \mathrm{E}-05$ & 5.5 \\
\hline Am-243 & $8.810 \mathrm{E}-05$ & 7.126E-06 & 8.1 & $2.675 E+00$ & 3.201E-01 & 12.0 & $3.400 \mathrm{E}-04$ & $2.519 \mathrm{E}-05$ & 7.4 & $4.992 \mathrm{E}-04$ & $3.349 \mathrm{E}-05$ & 6.7 & $6.820 \mathrm{E}-04$ & $3.574 \mathrm{E}-05$ & 5.2 & 4.503E-04 & $3.546 \mathrm{E}-05$ & 7.9 \\
\hline $\mathrm{Cm}-244$ & $1.771 \mathrm{E}-05$ & 2.505E-06 & 14.1 & 6.500E-01 & 1.300E-01 & 20.0 & $1.205 \mathrm{E}-04$ & $1.715 \mathrm{E}-05$ & 14.2 & $2.063 \mathrm{E}-04$ & $2.064 \mathrm{E}-05$ & 10.0 & $2.588 \mathrm{E}-04$ & $5.176 \mathrm{E}-05$ & 20.0 & $1.890 \mathrm{E}-04$ & $3.780 \mathrm{E}-05$ & 20.0 \\
\hline Cm-246 & $1.714 \mathrm{E}-07$ & 3.636E-08 & 21.2 & 6.789E-03 & 2.037E-03 & 30.0 & 2.200E-06 & $4.671 \mathrm{E}-07$ & 21.2 & 5.157E-06 & 7.794E-07 & 15.1 & 6.469E-06 & $1.941 \mathrm{E}-06$ & 30.0 & 4.961E-06 & $1.488 \mathrm{E}-06$ & 30.0 \\
\hline $\mathrm{Nd}-142$ & 2.144E-05 & 9.501E-07 & 4.4 & 4.181E-01 & 6.007E-02 & 14.4 & 5.595E-05 & $3.836 \mathrm{E}-06$ & 6.9 & $8.529 \mathrm{E}-05$ & $2.772 \mathrm{E}-06$ & 3.2 & & & & 7.265E-05 & $6.434 \mathrm{E}-06$ & 8.9 \\
\hline $\mathrm{Nd}-143$ & $1.062 \mathrm{E}-03$ & 3.789E-05 & 3.6 & $1.373 \mathrm{E}+01$ & 7.178E-01 & 5.2 & $1.223 \mathrm{E}-03$ & $5.422 \mathrm{E}-05$ & 4.4 & $1.251 \mathrm{E}-03$ & $3.309 \mathrm{E}-05$ & 2.6 & $1.173 \mathrm{E}-03$ & $6.301 \mathrm{E}-05$ & 5.4 & $1.194 \mathrm{E}-03$ & $3.860 \mathrm{E}-05$ & 3.2 \\
\hline $\mathrm{Nd}-145$ & $8.620 \mathrm{E}-04$ & 3.686E-05 & 4.3 & $1.219 \mathrm{E}+01$ & 6.170E-01 & 5.1 & $1.173 \mathrm{E}-03$ & $5.114 \mathrm{E}-05$ & 4.4 & $1.316 \mathrm{E}-03$ & $3.630 \mathrm{E}-05$ & 2.8 & $1.258 \mathrm{E}-03$ & $6.814 \mathrm{E}-05$ & 5.4 & $1.210 \mathrm{E}-03$ & $4.327 \mathrm{E}-05$ & 3.6 \\
\hline $\mathrm{Nd}-146$ & $8.864 \mathrm{E}-04$ & 2.577E- 05 & 2.9 & $1.377 \mathrm{E}+01$ & 6.078E-01 & 4.4 & $1.427 \mathrm{E}-03$ & 4.164E-05 & 2.9 & $1.759 \mathrm{E}-03$ & $3.906 \mathrm{E}-05$ & 2.2 & $1.716 \mathrm{E}-03$ & $8.584 \mathrm{E}-05$ & 5.0 & $1.581 \mathrm{E}-03$ & 4.684E-05 & 3.0 \\
\hline $\mathrm{Nd}-148$ & 4.684E-04 & $1.804 \mathrm{E}-05$ & 3.9 & $7.202 \mathrm{E}+00$ & 3.845E-01 & 5.3 & $6.985 \mathrm{E}-04$ & $3.088 \mathrm{E}-05$ & 4.4 & $8.588 \mathrm{E}-04$ & $2.244 \mathrm{E}-05$ & 2.6 & $9.137 \mathrm{E}-04$ & 7.513E-05 & 8.2 & 7.629E-04 & 4.380E-05 & 5.7 \\
\hline $\mathrm{Nd}-150$ & 2.257E-04 & $8.289 \mathrm{E}-06$ & 3.7 & $3.268 \mathrm{E}+00$ & $1.854 \mathrm{E}-01$ & 5.7 & $3.581 \mathrm{E}-04$ & $2.170 \mathrm{E}-05$ & 6.1 & $4.046 \mathrm{E}-04$ & $1.283 \mathrm{E}-05$ & 3.2 & 4.688E-04 & $2.880 \mathrm{E}-05$ & 6.1 & $3.911 \mathrm{E}-04$ & $2.635 \mathrm{E}-05$ & 6.7 \\
\hline Cs-133 & $1.416 \mathrm{E}-03$ & $1.605 \mathrm{E}-04$ & 11.3 & $1.991 \mathrm{E}+01$ & $3.186 \mathrm{E}+00$ & 16.0 & $2.074 \mathrm{E}-03$ & $3.318 \mathrm{E}-04$ & 16.0 & $2.022 \mathrm{E}-03$ & $1.618 \mathrm{E}-04$ & 8.0 & $1.951 \mathrm{E}-03$ & $3.121 \mathrm{E}-04$ & 16.0 & & & \\
\hline Cs-134 & $1.559 \mathrm{E}-04$ & $1.846 \mathrm{E}-05$ & 11.8 & $2.658 \mathrm{E}+00$ & $2.180 \mathrm{E}-01$ & 8.2 & 3.105E-04 & 2.133E-05 & 6.9 & $4.022 \mathrm{E}-04$ & $1.854 \mathrm{E}-05$ & 4.6 & $4.186 \mathrm{E}-04$ & $2.923 \mathrm{E}-05$ & 7.0 & $3.592 \mathrm{E}-04$ & $2.387 \mathrm{E}-05$ & 6.6 \\
\hline Cs-135 & $8.266 \mathrm{E}-04$ & $1.323 \mathrm{E}-04$ & 16.0 & $1.129 \mathrm{E}+01$ & $1.806 \mathrm{E}+00$ & 16.0 & $1.074 \mathrm{E}-03$ & $1.718 \mathrm{E}-04$ & 16.0 & $9.420 \mathrm{E}-04$ & $8.708 \mathrm{E}-05$ & 9.2 & $1.016 \mathrm{E}-03$ & $1.625 \mathrm{E}-04$ & 16.0 & & & \\
\hline Cs-137 & $1.585 \mathrm{E}-03$ & $1.250 \mathrm{E}-04$ & 7.9 & $2.292 \mathrm{E}+01$ & $1.560 \mathrm{E}+00$ & 6.8 & $2.312 \mathrm{E}-03$ & $1.431 \mathrm{E}-04$ & 6.2 & $2.681 \mathrm{E}-03$ & $1.186 \mathrm{E}-04$ & 4.4 & $2.754 \mathrm{E}-03$ & $1.839 \mathrm{E}-04$ & 6.7 & $2.576 \mathrm{E}-03$ & $1.584 \mathrm{E}-04$ & 6.1 \\
\hline Ce-140 & $1.576 \mathrm{E}-03$ & 4.729E- 05 & 3.0 & $2.313 \mathrm{E}+01$ & 8.379E-01 & 3.6 & $2.422 \mathrm{E}-03$ & 8.393E-05 & 3.5 & $2.796 \mathrm{E}-03$ & $6.456 \mathrm{E}-05$ & 2.3 & $2.850 \mathrm{E}-03$ & $1.647 \mathrm{E}-04$ & 5.8 & $2.746 \mathrm{E}-03$ & $1.899 \mathrm{E}-04$ & 6.9 \\
\hline Ce-142 & $1.459 \mathrm{E}-03$ & 4.041E-05 & 2.8 & $2.194 \mathrm{E}+01$ & 6.651E-01 & 3.0 & $2.191 \mathrm{E}-03$ & $1.348 \mathrm{E}-04$ & 6.2 & $2.558 \mathrm{E}-03$ & $5.614 \mathrm{E}-05$ & 2.2 & $2.616 \mathrm{E}-03$ & $1.506 \mathrm{E}-04$ & 5.8 & $2.420 \mathrm{E}-03$ & 1.669E-04 & 6.9 \\
\hline Ce-144 & $1.893 \mathrm{E}-04$ & $2.738 \mathrm{E}-05$ & 14.5 & $2.666 \mathrm{E}+00$ & 3.453E-01 & 13.0 & $2.617 \mathrm{E}-04$ & 3.437E-05 & 13.1 & $2.924 \mathrm{E}-04$ & $2.690 \mathrm{E}-05$ & 9.2 & 3.063E-04 & $1.193 \mathrm{E}-04$ & 39.0 & & & \\
\hline
\end{tabular}


Table 3.5. Isotopic concentrations - combined data (in $\left.\mathrm{g} / \mathrm{g} \mathbf{U}_{\text {initial }}\right)$ (cont.)

\begin{tabular}{|c|c|c|c|c|c|c|c|c|c|c|c|c|c|c|c|c|c|c|}
\hline \multirow{3}{*}{$\begin{array}{l}\text { Sample ID } \\
\text { Burnup }^{a} \\
\text { Nuclide }^{b}\end{array}$} & \multirow{2}{*}{\multicolumn{3}{|c|}{$\begin{array}{c}\text { E58-88 } \\
42.5 \\
\end{array}$}} & \multirow{2}{*}{\multicolumn{3}{|c|}{$\frac{\text { E58-148 }}{54.8}$}} & \multirow{2}{*}{\multicolumn{3}{|c|}{$\begin{array}{c}\text { E58-260 } \\
646\end{array}$}} & \multirow{2}{*}{\multicolumn{3}{|c|}{$\frac{\text { E58-700 }}{77.0}$}} & \multirow{2}{*}{\multicolumn{3}{|c|}{$\frac{165-2 a}{78.3}$}} & \multirow{2}{*}{\multicolumn{3}{|c|}{$\frac{160-800}{70.9}$}} \\
\hline & & & & & & & & & & & & & & & & & & \\
\hline & $\begin{array}{c}\begin{array}{c}\text { Mass } \\
\% \mathrm{~g} / \mathrm{g}^{328} \mathrm{U}\end{array} \\
\end{array}$ & $\begin{array}{c}\begin{array}{c}\text { Uncert } \\
\% \mathrm{~g} / \mathrm{g}^{238} \mathrm{U}\end{array} \\
\end{array}$ & $\begin{array}{c}\text { Uncerte }^{e} \\
(\%)\end{array}$ & $\begin{array}{c}\text { Mass } \\
\% \mathrm{~g} / \mathrm{g}^{238} \mathrm{U}\end{array}$ & $\begin{array}{c}\text { Uncert } \\
\% \mathrm{~g} / \mathrm{g}^{238} \mathrm{U}\end{array}$ & $\begin{array}{l}\text { Uncert } \\
(\%)\end{array}$ & $\begin{array}{c}\text { Mass } \\
\% \mathrm{~g} / \mathrm{g}^{238} \mathrm{U}\end{array}$ & $\begin{array}{c}\text { Uncert } \\
\% \mathrm{~g}^{2} / \mathrm{g}^{28} \mathrm{U}\end{array}$ & $\begin{array}{c}\text { Uncert } \\
(\%)\end{array}$ & $\begin{array}{c}\text { Mass } \\
\% \mathrm{~g} / \mathrm{g}^{238} \mathrm{U}\end{array}$ & $\begin{array}{c}\text { Uncert } \\
\% \mathrm{~g} / \mathrm{g}^{28} \mathrm{U}\end{array}$ & $\begin{array}{c}\text { Uncert } \\
(\%)\end{array}$ & $\begin{array}{c}\text { Mass } \\
\% \mathrm{~g} / \mathrm{g}^{238} \mathrm{U}\end{array}$ & $\begin{array}{c}\text { Uncert } \\
\% \mathrm{~g} / \mathrm{g}^{38} \mathrm{U}\end{array}$ & $\begin{array}{c}\text { Uncert } \\
(\%)\end{array}$ & $\begin{array}{c}\text { Mass } \\
\%{\mathrm{~g} / \mathrm{g}^{238} \mathrm{U}}\end{array}$ & $\begin{array}{c}\text { Uncert } \\
\% \mathrm{~g} / \mathrm{g}^{238} \mathrm{U}\end{array}$ & $\begin{array}{c}\text { Uncert } \\
(\%)\end{array}$ \\
\hline Sm-147 & $2.632 \mathrm{E}-04$ & $1.431 \mathrm{E}-05$ & 5.4 & $3.244 \mathrm{E}+00$ & $1.558 \mathrm{E}-01$ & 4.8 & $2.565 \mathrm{E}-04$ & $2.346 \mathrm{E}-00$ & 9.1 & $2.579 \mathrm{E}-04$ & $1.108 \mathrm{E}-05$ & 4.3 & $2.837 \mathrm{E}-04$ & $1.755 \mathrm{E}-05$ & 6.2 & & & \\
\hline Sm-148 & $1.873 \mathrm{E}-04$ & $8.217 \mathrm{E}-06$ & 4.4 & $3.267 \mathrm{E}+00$ & $1.534 \mathrm{E}-01$ & 4.7 & $3.490 \mathrm{E}-04$ & $1.757 \mathrm{E}-05$ & 5.0 & 4.531E-04 & $1.391 \mathrm{E}-05$ & 3.1 & $5.029 \mathrm{E}-04$ & $3.077 \mathrm{E}-05$ & 6.1 & $4.353 \mathrm{E}-04$ & $3.550 \mathrm{E}-05$ & 8.2 \\
\hline Sm-149 & $3.321 \mathrm{E}-06$ & 3.785E-07 & 11.4 & 4.304E-02 & $5.669 \mathrm{E}-03$ & 13.2 & $3.509 \mathrm{E}-06$ & $4.776 \mathrm{E}-07$ & 13.6 & $3.474 \mathrm{E}-06$ & $2.902 \mathrm{E}-07$ & 8.4 & 3.433E-06 & $8.695 \mathrm{E}-07$ & 25.3 & $3.710 \mathrm{E}-06$ & $1.765 \mathrm{E}-06$ & 47.6 \\
\hline Sm-150 & $3.248 \mathrm{E}-04$ & $1.551 \mathrm{E}-05$ & 4.8 & $5.144 \mathrm{E}+00$ & $2.349 \mathrm{E}-01$ & 4.6 & $5.012 \mathrm{E}-04$ & $2.518 \mathrm{E}-05$ & 5.0 & $5.975 \mathrm{E}-04$ & $1.821 \mathrm{E}-05$ & 3.0 & $5.869 \mathrm{E}-04$ & $3.560 \mathrm{E}-05$ & 6.1 & $5.996 \mathrm{E}-04$ & $4.897 \mathrm{E}-05$ & 8.2 \\
\hline Sm-151 & $1.419 \mathrm{E}-05$ & $9.710 \mathrm{E}-07$ & 6.8 & $1.684 \mathrm{E}-01$ & $1.224 \mathrm{E}-02$ & 7.3 & $1.503 \mathrm{E}-05$ & $9.861 \mathrm{E}-07$ & 6.6 & $1.747 \mathrm{E}-05$ & $6.323 \mathrm{E}-07$ & 3.6 & $1.710 \mathrm{E}-05$ & $1.843 \mathrm{E}-06$ & 10.8 & $1.704 \mathrm{E}-05$ & $1.670 \mathrm{E}-06$ & 9.8 \\
\hline Sm-152 & $1.212 \mathrm{E}-04$ & $3.587 \mathrm{E}-06$ & 3.0 & $1.685 \mathrm{E}+00$ & $7.510 \mathrm{E}-02$ & 4.5 & $1.553 \mathrm{E}-04$ & $6.722 \mathrm{E}-06$ & 4.3 & $1.725 \mathrm{E}-04$ & $5.025 \mathrm{E}-06$ & 2.9 & $1.812 \mathrm{E}-04$ & 8.793E-06 & 4.9 & $1.730 \mathrm{E}-04$ & $1.277 \mathrm{E}-05$ & 7.4 \\
\hline Sm-154 & 4.044E-05 & 2.619E-06 & 6.5 & $6.144 \mathrm{E}-01$ & $3.291 \mathrm{E}-02$ & 5.4 & $6.254 \mathrm{E}-05$ & $5.421 \mathrm{E}-06$ & 8.7 & 8.653E-05 & 3.033E-06 & 3.5 & $1.055 \mathrm{E}-04$ & $8.924 \mathrm{E}-06$ & 8.5 & $9.299 \mathrm{E}-05$ & 7.778E-06 & 8.4 \\
\hline Eu-153 & $1.564 \mathrm{E}-04$ & 9.083E-06 & 5.8 & $2.443 \mathrm{E}+00$ & $1.216 \mathrm{E}-01$ & 5.0 & $2.483 \mathrm{E}-04$ & $2.191 \mathrm{E}-05$ & 8.8 & $2.764 \mathrm{E}-04$ & 9.856E-06 & 3.6 & $2.880 \mathrm{E}-04$ & $1.373 \mathrm{E}-05$ & 4.8 & & & \\
\hline Eu-154 & 2.192E-05 & $2.598 \mathrm{E}-06$ & 11.8 & $3.686 \mathrm{E}-01$ & $2.289 \mathrm{E}-02$ & 6.2 & $3.620 \mathrm{E}-05$ & $4.756 \mathrm{E}-06$ & 13.1 & 3.695E-05 & $2.036 \mathrm{E}-06$ & 5.5 & $4.986 \mathrm{E}-05$ & $5.280 \mathrm{E}-06$ & 10.6 & & & \\
\hline Eu-155 & $5.714 \mathrm{E}-06$ & 3.873E-07 & 6.8 & $1.068 \mathrm{E}-01$ & $1.011 \mathrm{E}-02$ & 9.5 & $1.078 \mathrm{E}-05$ & $1.032 \mathrm{E}-06$ & 9.6 & $1.169 \mathrm{E}-05$ & $6.206 \mathrm{E}-07$ & 5.3 & $1.183 \mathrm{E}-05$ & $1.361 \mathrm{E}-06$ & 11.5 & & & \\
\hline Gd-154 & $8.228 \mathrm{E}-06$ & $2.700 \mathrm{E}-07$ & 3.3 & $1.674 \mathrm{E}-01$ & $1.545 \mathrm{E}-02$ & 9.2 & $1.452 \mathrm{E}-05$ & $8.302 \mathrm{E}-07$ & 5.7 & 1.983E-05 & 7.514E- -07 & 3.8 & $2.505 \mathrm{E}-00$ & 4.210E-06 & 16.8 & $1.795 \mathrm{E}-05$ & $1.514 \mathrm{E}-06$ & 8.4 \\
\hline Gd-155 & $2.777 \mathrm{E}-06$ & $4.700 \mathrm{E}-07$ & 16.9 & $5.305 \mathrm{E}-02$ & $8.761 \mathrm{E}-03$ & 16.5 & $4.991 \mathrm{E}-06$ & $4.761 \mathrm{E}-07$ & 9.5 & $6.411 \mathrm{E}-06$ & 2.831E-07 & 4.4 & $5.388 \mathrm{E}-06$ & $5.067 \mathrm{E}-07$ & 9.4 & & & \\
\hline Gd-156 & $8.890 \mathrm{E}-05$ & 2.475E-06 & 2.8 & $2.092 \mathrm{E}+00$ & $1.909 \mathrm{E}-01$ & 9.1 & $2.670 \mathrm{E}-04$ & $1.014 \mathrm{E}-05$ & 3.8 & $4.248 \mathrm{E}-04$ & $1.159 \mathrm{E}-05$ & 2.7 & $4.418 \mathrm{E}-04$ & $4.066 \mathrm{E}-05$ & 9.2 & $3.920 \mathrm{E}-04$ & $1.224 \mathrm{E}-05$ & 3.1 \\
\hline Gd-158 & $1.576 \mathrm{E}-05$ & $5.853 \mathrm{E}-07$ & 3.7 & $3.285 \mathrm{E}-01$ & $3.393 \mathrm{E}-02$ & 10.3 & $3.924 \mathrm{E}-05$ & $1.696 \mathrm{E}-06$ & 4.3 & $6.249 \mathrm{E}-05$ & $1.826 \mathrm{E}-06$ & 2.9 & $6.575 \mathrm{E}-05$ & $8.085 \mathrm{E}-06$ & 12.3 & $5.715 \mathrm{E}-05$ & $3.360 \mathrm{E}-06$ & 5.9 \\
\hline Gd-160 & $1.288 \mathrm{E}-06$ & $1.675 \mathrm{E}-07$ & 13.0 & $2.004 \mathrm{E}-02$ & $6.388 \mathrm{E}-03$ & 31.9 & 2.186E-06 & $4.350 \mathrm{E}-07$ & 19.9 & $2.909 \mathrm{E}-06$ & $1.281 \mathrm{E}-07$ & 4.4 & $3.477 \mathrm{E}-06$ & $4.355 \mathrm{E}-07$ & 12.5 & $2.992 \mathrm{E}-06$ & $1.212 \mathrm{E}-07$ & 4.1 \\
\hline Ru-103 & & & & & & & & & & & & & $6.336 \mathrm{E}-05$ & $9.470 \mathrm{E}-06$ & 14.9 & & & \\
\hline Ru-106 & $1.385 \mathrm{E}-04$ & $1.444 \mathrm{E}-05$ & 10.4 & $2.170 \mathrm{E}+00$ & $1.863 \mathrm{E}-01$ & 8.6 & $2.366 \mathrm{E}-04$ & $1.792 \mathrm{E}-05$ & 7.6 & $2.885 \mathrm{E}-04$ & $1.581 \mathrm{E}-05$ & 5.5 & $2.925 \mathrm{E}-04$ & $2.412 \mathrm{E}-05$ & 8.2 & & & \\
\hline La-139 & $1.496 \mathrm{E}-03$ & $2.394 \mathrm{E}-04$ & 16.0 & & & & $2.090 \mathrm{E}-03$ & $3.344 \mathrm{E}-04$ & 16.0 & $2.564 \mathrm{E}-03$ & 4.102E-04 & 16.0 & & & & $2.343 \mathrm{E}-03$ & 3.749E-04 & 16.0 \\
\hline Rh-103 & & & & & & & & & & & & & & & & $7.394 \mathrm{E}-04$ & $1.479 \mathrm{E}-04$ & 20.0 \\
\hline Тс-99 & $9.591 \mathrm{E}-04$ & 1.535E-04 & 16.0 & & & & & & & & & & & & & $1.477 \mathrm{E}-03$ & $2.363 \mathrm{E}-04$ & 16.0 \\
\hline
\end{tabular}

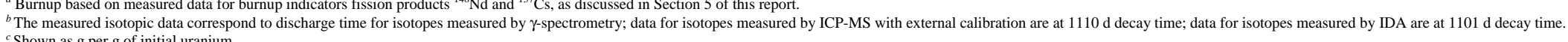
Shown as g per g of initial uranium.

Relative measurement uncertainty. 


\section{ASSEMBLY DESIGN AND IRRADIATION HISTORY DATA}

This section presents information on the fuel assembly geometry, irradiation history, and sample burnup necessary for developing a computational model to calculate the isotopic composition of the samples under consideration. For the cases in which information was unavailable, assumptions are stated for derived data used in calculations.

The analyzed samples were selected from three fuel rods, identified as WZR0058, WZtR165, and WZtR160, that were irradiated in the Vandellós II reactor for five consecutive cycles, from cycle 7 through cycle 11. The initial enrichment of these fuel rods was $4.4982 \mathrm{wt} \%{ }^{235} \mathrm{U}$. Rods WZR0058 and WZtR165 were included in the same fuel assembly in each of the five irradiation cycles. During cycles 7 through 10, rods WZR0058 and WZtR165 were part of assembly EC45; whereas, during the same cycles, fuel rod WZtR160 was included in assembly EC46. For the last irradiation cycle, cycle 11, the three rods were removed from original assemblies EC45 and EC46 and inserted into the rebuilt assembly EF05. Assembly EF05 had an estimated burnup of $26.5 \mathrm{GWd} / \mathrm{MTU}$ at the beginning of cycle (BOC) for cycle 11 (BOC-11); the initial enrichment of the fuel rods in assembly EF05, other than the three measured rods mentioned, was $4.240 \mathrm{wt} \%{ }^{235} \mathrm{U}$.

The layout of the Vandellós II fuel assemblies, with a $17 \times 17$ configuration, is illustrated in Figure 4.1, which shows the locations of the fuel rods from which the samples were selected. Each fuel assembly included 264 fuel rods and 25 guide tubes. No absorber rods were present in assemblies EC45, EC46, or EF05 in any of the irradiation cycles.

The loading positions of the fuel rods in the assembly and of the assemblies in the core are listed in Table 4.1. The locations of the assemblies EC45 and EC45 in the core during irradiation are also illustrated in Figure 4.2. Assembly design data are shown in Table 4.2. During cycles 7 through 10, all three measured rods were located at the periphery of the fuel assembly: rod WZR0058 at the east side of assembly EC45, rod WZtR165 at the west side of assembly EC45, and rod WZtR160 at the east side of assembly EC46. For modeling purposes the information for assemblies located east and west of EC45, as well as the assembly neighboring EC46 to the east, is required to accurately account for the influences of the neighbor assembly rods residing adjacent to measured rods. Data on these adjacent assemblieslocation in core, initial fuel enrichment, and burnup at BOC-for each of the irradiation cycles 7 through 10 are provided in Table 4.3. As noted, assembly EC46 was located at the edge of the core during cycle 10.

Operating history data, including irradiation cycle start and end dates, cycle duration and down days, and cycle burnup (Ref. 9) for each of the three rods WZR0058, WZtR165, and WZtR160 are shown in Table 4.4. Sample burnups based on operating data are available (Ref. 9) for some samples selected from rod WZR0058 and for the sample selected from rod WZtR165. Sample burnup based on operation data for the sample from rod WZtR160 was not available; the burnup value used in the initial simulations for this sample was a value estimated by Studsvik using measured actinide and fission product concentrations and CASMO burnup calculations (Ref. 6).

The fuel rod burnups based on operator data are presented in Table 4.5. The sample burnups and powers based on operator data are included in Table 4.6. As further discussed in Section 5 of this report, the sample burnups were later calculated based on the measured data for the burnup indicators fission products ${ }^{148} \mathrm{Nd}$ and ${ }^{137} \mathrm{Cs}$, and the power data shown in Table 4.6 were renormalized accordingly.

The power values for each sample and in each irradiation cycle shown in Table 4.6 were calculated based on the burnups and the available operating history data (as shown in Tables 4.4 and 4.5 ) for the fuel rods 
from which the samples were selected. It was assumed that the sample cycle burnup had the same distribution as the cycle burnup of the fuel rod from which the sample was selected. The power $P_{i}^{s}$ in cycle $i$ for sample $s$ was calculated as:

$$
P_{i}^{s}=\frac{1}{\Delta t_{i}} B_{s}^{i}=\frac{1}{\Delta t_{i}}\left(B^{s} \frac{B_{i}^{\text {rod }, s}}{\sum_{i=7}^{11} B_{i}^{\text {rod,s }}}\right) \quad i=7, . ., 11
$$

$B_{s}^{i}$ in Eq. (4.1) stands for sample cycle burnup in cycle $i, \Delta t_{i}$ is the duration of cycle $i$, and $B_{i}^{\text {rod,s }}$ represents the cycle burnup in cycle $i$ of the fuel rod from which sample $s$ was selected.

Temperature and density data of the water moderator at the sample level (with respect to the axial location along the fuel rod), as listed in Table 4.7, were available (Ref. 9) for most of the samples except sample 160-800. For this sample the data corresponding to sample E58-796, located at a similar axial level, were used instead. The concentration of soluble boron in the moderator as a function of time was available from Ref. 9 and is illustrated in Figure 4.3. As shown, the variation of boron was linear during an irradiation cycle, with the exception of the first 10 to 15 days of the cycle. For the time points between day 10 for cycles 7 through 10 (day 15 for cycle 11) and the last day of the cycle, a linear fit was performed on the available data and used in the calculations. The variation of the boron concentration for each irradiation cycle is presented in Table 4.8, which includes boron concentration data for the first 10 or 15 days and the last day of the cycle. The data in Table 4.8 that correspond to day 10 and the last day of the cycle completely define the line that expresses the linear variation with time of the boron concentration on this time range. 


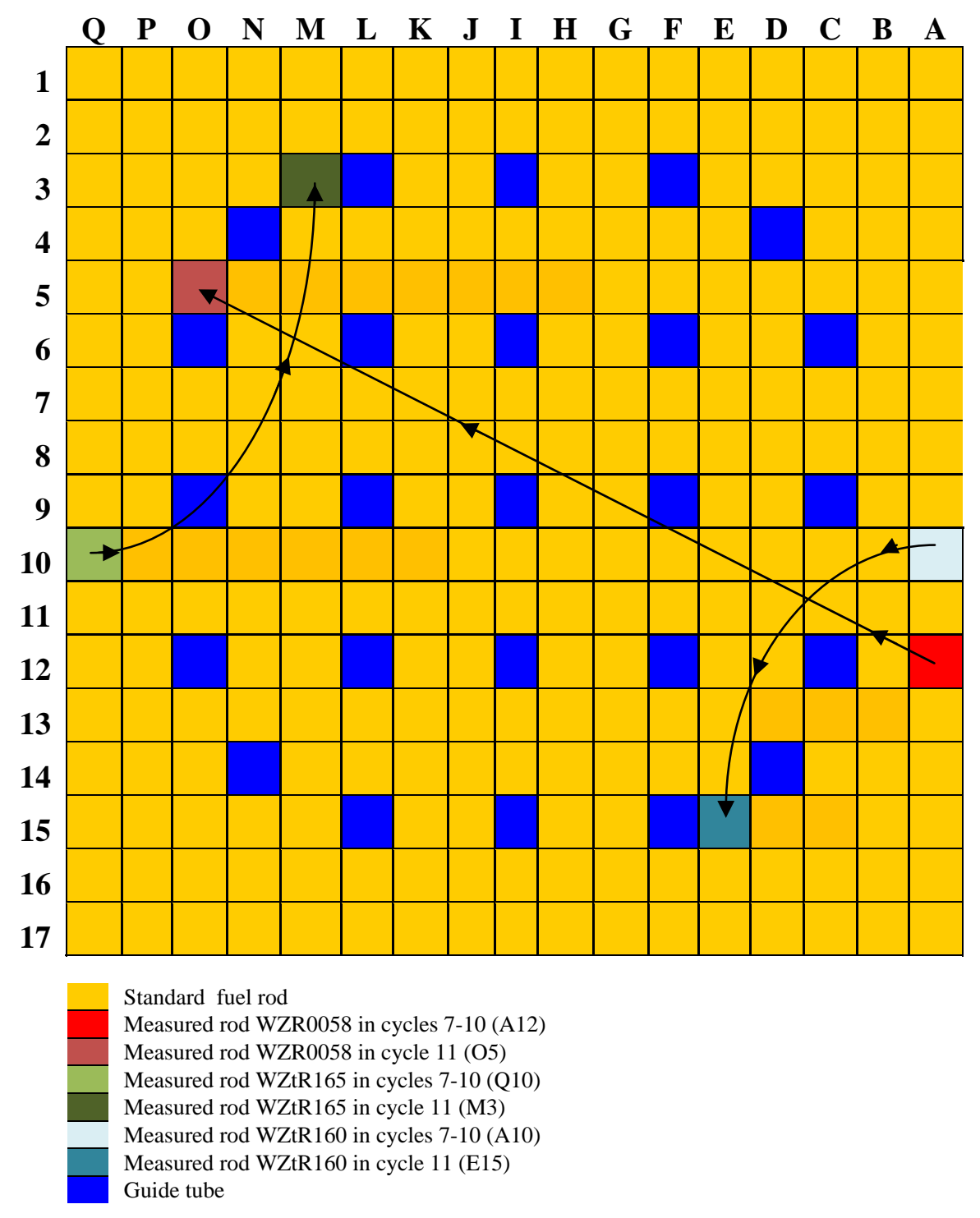

Figure 4.1. Assembly layout for Vandellós II samples. 
Table 4.1. Fuel rods and assemblies loading locations

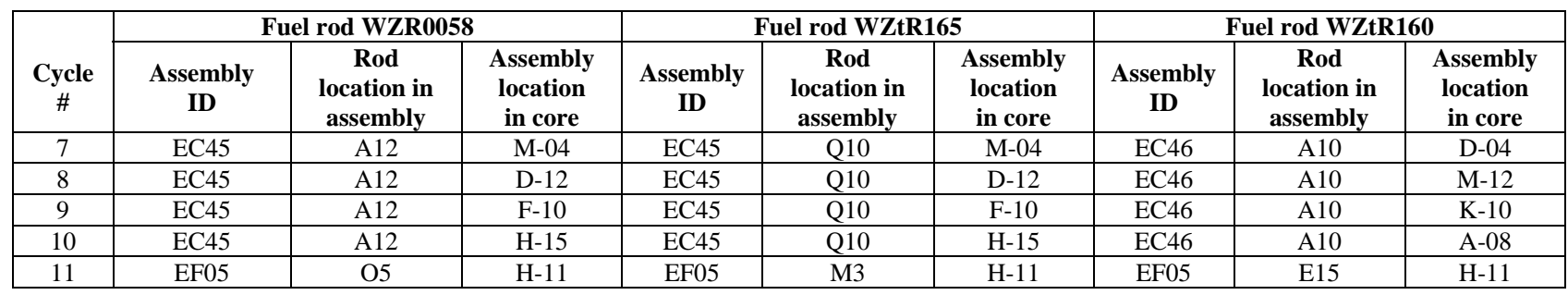

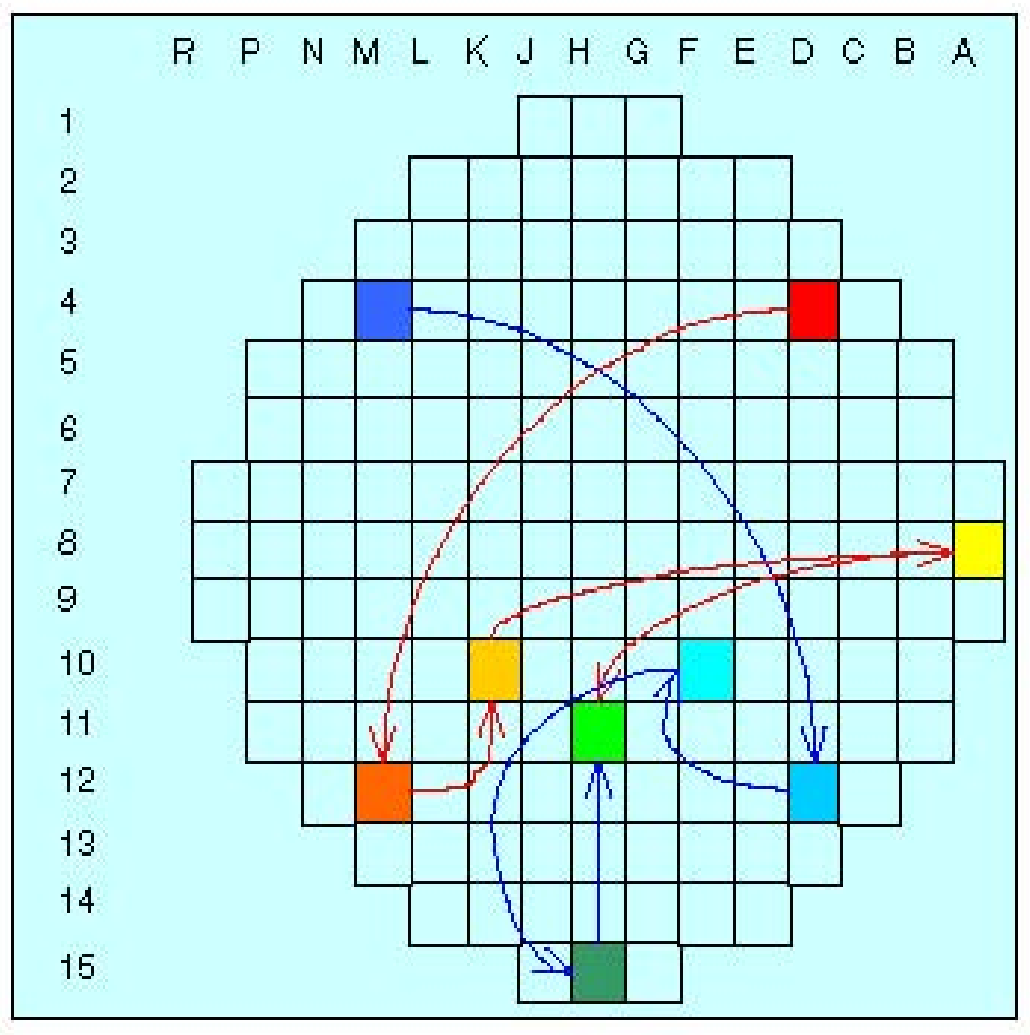

Figure 4.2. Vandellós II core layout. 
Table 4.2. Assembly design data

\begin{tabular}{|c|c|}
\hline Parameter & Data \\
\hline \multicolumn{2}{|l|}{ Assembly and reactor data } \\
\hline Reactor & Vandellós II \\
\hline Operating pressure (psia) & 2250 \\
\hline Lattice geometry & $17 \times 17$ \\
\hline Rod pitch (cm) & 1.26 \\
\hline Number of fuel rods & 264 \\
\hline Number of guide/instrument tubes & 25 \\
\hline Assembly pitch (cm) & 21.504 \\
\hline Active fuel rod length (cm) & 365.76 \\
\hline Sample location $^{a}(\mathrm{~cm})$ & See Table 2.1 \\
\hline \multicolumn{2}{|l|}{ Fuel rod data } \\
\hline Fuel material type & $\mathrm{UO}_{2}$ \\
\hline Fuel pellet density $\left(\% \mathrm{TD}^{b}\right)$ & 96.016 \\
\hline Fuel pellet diameter $(\mathrm{cm})$ & 0.8191 \\
\hline Fuel temperature (K) & 928 \\
\hline \multicolumn{2}{|l|}{ U isotopic composition (wt \%) } \\
\hline${ }^{234} \mathrm{U}$ & 0.0410 \\
\hline${ }^{235} \mathrm{U}$ & 4.4982 \\
\hline${ }^{236} \mathrm{U}$ & 0.0030 \\
\hline${ }^{238} \mathrm{U}$ & 95.4578 \\
\hline Clad temperature (K) & 607 \\
\hline Clad inner diameter (cm) & 0.8356 \\
\hline Clad outer diameter (cm) & 0.950 \\
\hline Clad material density $\left(\mathrm{g} / \mathrm{cm}^{3}\right)$ & 6.5 \\
\hline Clad material & Zirlo \\
\hline \multicolumn{2}{|l|}{ Clad material composition (wt \%) } \\
\hline $\mathrm{Zr}$ & 97.9 \\
\hline Sn & 1.0 \\
\hline $\mathrm{Fe}$ & 0.1 \\
\hline $\mathrm{Nb}$ & 1.0 \\
\hline \multicolumn{2}{|l|}{ Moderator data } \\
\hline Inlet temperature (K) & 565 \\
\hline Outlet temperature (K) & 601 \\
\hline Temperature at sample level (K) & See Table 4.7 \\
\hline Density at sample level $\left(\mathrm{g} / \mathrm{cm}^{3}\right)$ & See Table 4.7 \\
\hline Soluble boron content (ppm) & See Table 4.8 \\
\hline \multicolumn{2}{|l|}{ Guide tube data } \\
\hline Guide tube material & Zirlo \\
\hline Inner diameter (cm) & 1.125 \\
\hline Outer diameter (cm) & 1.205 \\
\hline
\end{tabular}

${ }^{a}$ Relative to the bottom of the active fuel region.

${ }^{b} \mathrm{TD}=$ theoretical density $\left(10.96 \mathrm{~g} / \mathrm{cm}^{3}\right)$. 
Table 4.3. Adjacent assembly data

\begin{tabular}{|c|c|c|c|c|c|c|c|c|c|}
\hline Rod & \multicolumn{3}{|c|}{ WZR0058 } & \multicolumn{3}{|c|}{ WZtR165 } & \multicolumn{3}{|c|}{ WZtR160 } \\
\hline Assembly & \multicolumn{3}{|c|}{ EC45 } & \multicolumn{3}{|c|}{ EC45 } & \multicolumn{3}{|c|}{ EC46 } \\
\hline $\begin{array}{l}\text { Adjacent } \\
\text { assembly }\end{array}$ & \multicolumn{3}{|c|}{ East of EC45 } & \multicolumn{3}{|c|}{ West of EC45 } & \multicolumn{3}{|c|}{ East of EC46 } \\
\hline $\begin{array}{c}\text { Cycle } \\
\#\end{array}$ & $\begin{array}{l}\text { Location } \\
\text { in core }\end{array}$ & $\begin{array}{c}\text { Enrichment } \\
\left(\mathbf{w t} \%{ }^{235} \mathrm{U}\right)\end{array}$ & $\begin{array}{c}\text { BOC } \\
\text { burnup } \\
\text { (GWd/t) }\end{array}$ & $\begin{array}{l}\text { Location } \\
\text { in core }\end{array}$ & $\begin{array}{c}\text { Enrichment } \\
\left(w t \%{ }^{235} U\right)\end{array}$ & $\begin{array}{c}\text { BOC } \\
\text { burnup } \\
\text { (GWd/t) }\end{array}$ & $\begin{array}{l}\text { Location } \\
\text { in core }\end{array}$ & $\begin{array}{c}\text { Enrichment } \\
\left(\mathbf{w t} \%{ }^{235} \mathrm{U}\right)\end{array}$ & $\begin{array}{c}\text { BOC } \\
\text { burnup } \\
\text { (GWd/t) }\end{array}$ \\
\hline 7 & L4 & 3.60 & 22.125 & N4 & 3.60 & 32.204 & $\mathrm{C} 4$ & 3.60 & 32.204 \\
\hline 9 & E10 & 4.23 & 0 & G10 & 3.60 & 13.648 & $\mathrm{~J} 10$ & 3.60 & 13.648 \\
\hline 10 & G15 & 3.60 & 34.678 & J15 & 3.60 & 34.678 & $\mathrm{NA}^{a}$ & NA & NA \\
\hline
\end{tabular}

Table 4.4. Irradiation history data

\begin{tabular}{|c|c|c|c|c|}
\hline Cycle \# & Start date & End date & Irradiation (days) & Down (days) \\
\hline 7 & $06 / 19 / 94$ & $06 / 12 / 95$ & 358 & 33 \\
\hline 8 & $07 / 15 / 95$ & $06 / 09 / 96$ & 330 & 35 \\
\hline 9 & $07 / 14 / 96$ & $08 / 25 / 97$ & 407 & 31 \\
\hline 10 & $09 / 25 / 97$ & $03 / 14 / 99$ & 535 & 50 \\
\hline 11 & $05 / 03 / 99$ & $09 / 10 / 00$ & 496 & \\
\hline
\end{tabular}

Table 4.5. Fuel rod burnup data

\begin{tabular}{|c|c|c|c|c|c|c|}
\hline \multirow{2}{*}{ Cycle \# } & \multicolumn{2}{|c|}{ Rod WZR058 } & \multicolumn{2}{c|}{ Rod WZtR165 } & \multicolumn{2}{c|}{ Rod WZtR160 } \\
\cline { 2 - 7 } & $\begin{array}{c}\text { Cycle burnup } \\
\text { (MWd/MTU) }\end{array}$ & $\begin{array}{c}\text { Fraction of } \\
\text { total burnup }\end{array}$ & $\begin{array}{c}\text { Cycle burnup } \\
\text { (MWd/MTU) }\end{array}$ & $\begin{array}{c}\text { Fraction of } \\
\text { total burnup }\end{array}$ & $\begin{array}{c}\text { Cycle burnup } \\
\text { (MWd/MTU) }\end{array}$ & $\begin{array}{c}\text { Fraction of } \\
\text { total burnup }\end{array}$ \\
\hline 7 & 17,475 & 0.255 & 13,083 & 0.187 & 13,083 & 0.197 \\
\hline 8 & 8,938 & 0.130 & 14,467 & 0.207 & 14,467 & 0.218 \\
\hline 9 & 17,675 & 0.258 & 16,899 & 0.242 & 16,877 & 0.254 \\
\hline 10 & 6,025 & 0.088 & 6,663 & 0.095 & 3,152 & 0.047 \\
\hline 11 & 18,387 & 0.268 & 18,851 & 0.269 & 18,921 & 0.285 \\
\hline
\end{tabular}

${ }^{a}$ As provided in ENUSA COM-006998, Rev. 1, 4/4/2008, from A. Romano.

Table 4.6. Cycle power data for each sample

\begin{tabular}{|l|c|r|r|r|r|r|}
\hline \multirow{2}{*}{ Sample ID } & \multirow{2}{*}{$\begin{array}{c}\text { Sample burnup }^{\boldsymbol{a}} \\
\text { (GWd/MTU) }\end{array}$} & \multicolumn{5}{|c|}{$\begin{array}{c}\text { Sample cycle power } \\
\text { (MW/MTU) }\end{array}$} \\
\cline { 3 - 7 } & & Cycle 7 & Cycle 8 & Cycle 9 & Cycle 10 & Cycle 11 \\
\hline E58-88 & 43.524 & 31.015 & 17.209 & 27.593 & 7.156 & 23.554 \\
E58-148 & 51.332 & 36.579 & 20.297 & 32.543 & 8.439 & 27.780 \\
E58-260 & 63.008 & 44.899 & 24.913 & 39.946 & 10.359 & 34.098 \\
E58-700 & 74.566 & 53.135 & 29.483 & 47.273 & 12.259 & 40.353 \\
$165-2 a$ & 76.323 & 39.867 & 47.825 & 45.295 & 13.586 & 41.461 \\
$160-800$ & 72.800 & 40.007 & 47.993 & 45.395 & 6.450 & 41.761 \\
\hline
\end{tabular}


Table 4.7. Moderator temperature and density data

\begin{tabular}{|l|l|c|c|c|}
\hline Sample ID & \multicolumn{1}{|c|}{ Data } & Cycles 7 through 9 & Cycle 10 & Cycle 11 \\
\hline E58-88 & Temperature (K) & 565.4 & 565.4 & 563.7 \\
& Density $\left(\mathrm{g} / \mathrm{cm}^{3}\right)$ & 0.7421 & 0.7425 & 0.7456 \\
\hline E58-148 & Temperature (K) & 566 & 565.4 & 564.3 \\
& Density $\left(\mathrm{g} / \mathrm{cm}^{3}\right)$ & 0.7411 & 0.7423 & 0.7446 \\
\hline E58-263 & Temperature (K) & 567.1 & 565.4 & 565.4 \\
& Density $\left(\mathrm{g} / \mathrm{cm}^{3}\right)$ & 0.7387 & 0.7418 & 0.7421 \\
\hline E58-773 & Temperature (K) & 573.2 & 567.1 & 572.1 \\
& Density $\left(\mathrm{g} / \mathrm{cm}^{3}\right)$ & 0.7263 & 0.7392 & 0.729 \\
\hline E58-793 & Temperature (K) & 573.7 & 567.1 & 572.1 \\
& Density $\left(\mathrm{g} / \mathrm{cm}^{3}\right)$ & 0.7258 & 0.7391 & 0.7285 \\
\hline E58-796 & Temperature (K) & 573.7 & 567.1 & 572.1 \\
& Density $\left(\mathrm{g} / \mathrm{cm}^{3}\right)$ & 0.7258 & 0.7391 & 0.7285 \\
\hline 165-2a & Temperature (K) & 574.3 & 569.3 & 573.2 \\
& Density $\left(\mathrm{g} / \mathrm{cm}^{3}\right)$ & 0.7242 & 0.7348 & 0.7268 \\
\hline
\end{tabular}

Boron history (Vandellos 2; C7-C11)

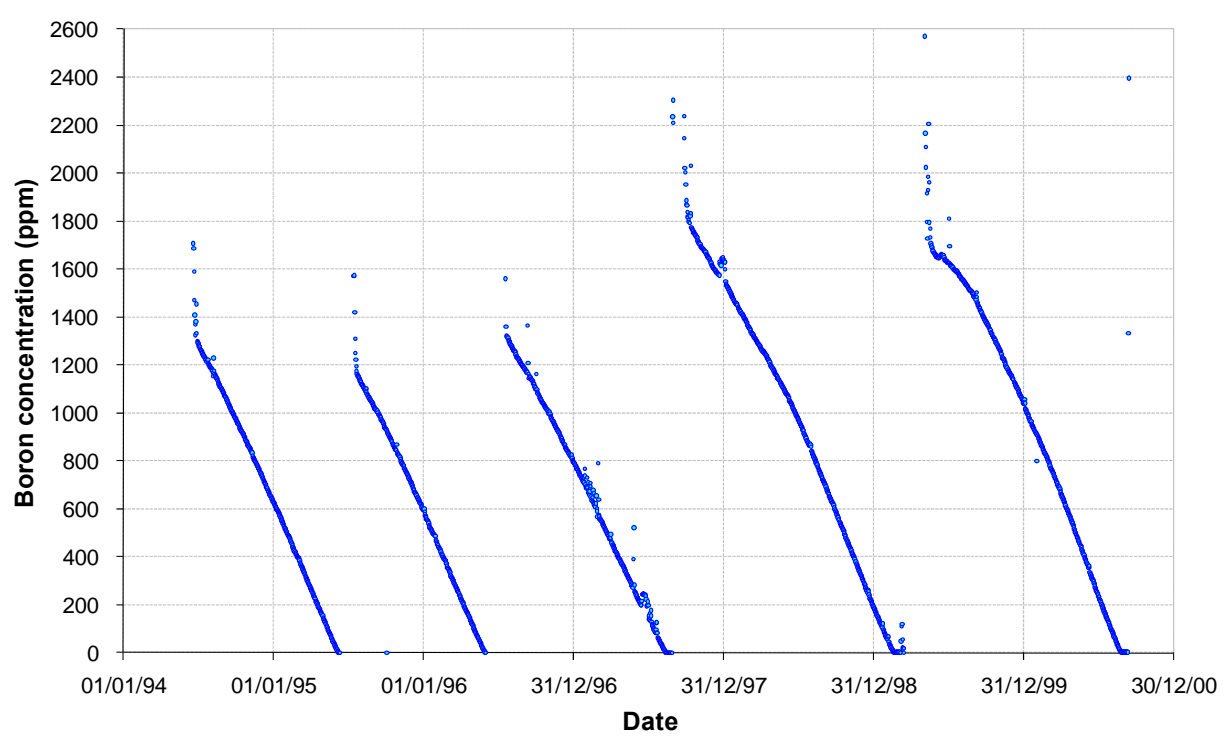

Figure 4.3. Boron concentration vs. irradiation time (from Ref. 9). 
Table 4.8. Boron concentration in moderator

\begin{tabular}{|c|c|c|c|c|c|c|c|c|c|c|c|c|c|c|}
\hline \multicolumn{3}{|c|}{ Cycle 7} & \multicolumn{3}{|c|}{ Cycle 8} & \multicolumn{3}{|c|}{ Cycle 9} & \multicolumn{3}{|c|}{ Cycle 10} & \multicolumn{3}{|c|}{ Cycle 11} \\
\hline $\begin{array}{l}T_{\text {Time }}^{a} \\
\text { (days) }\end{array}$ & $\begin{array}{l}\text { Boron } \\
\text { (ppm) }\end{array}$ & Ratio $^{b}$ & $\begin{array}{l}T_{\text {Time }}^{a} \\
\text { (days) }\end{array}$ & $\begin{array}{l}\text { Boron } \\
\text { (ppm) }\end{array}$ & Ratio & $\begin{array}{l}T_{\text {Time }}{ }^{a} \\
\text { (days) }\end{array}$ & $\begin{array}{l}\text { Boron } \\
\text { (ppm) }\end{array}$ & Ratio & $\begin{array}{l}\text { Time }^{a} \\
\text { (days) }\end{array}$ & $\begin{array}{l}\text { Boron } \\
\text { (ppm) }\end{array}$ & Ratio & $\begin{array}{l}T_{\text {Time }}^{a} \\
\text { (days) }\end{array}$ & $\begin{array}{l}\text { Boron } \\
\text { (ppm) }\end{array}$ & Ratio \\
\hline 0 & 1707 & 1.000 & 0 & 1572 & 1.000 & 0 & 1559 & 1.000 & 2237 & 0 & 1.000 & 0 & 2570 & 1.000 \\
\hline 1 & 1686 & 0.988 & 1 & 1574 & 1.001 & 1 & 1359 & 0.872 & 2145 & 1 & 0.959 & 2 & 2166 & 0.843 \\
\hline 2 & 1590 & 0.931 & 2 & 1420 & 0.903 & 2 & 1321 & 0.847 & 2022 & 2 & 0.904 & 3 & 2109 & 0.821 \\
\hline 3 & 1469 & 0.860 & 3 & 1310 & 0.833 & 3 & 1320 & 0.847 & 2002 & 3 & 0.895 & 4 & 2023 & 0.787 \\
\hline 4 & 1408 & 0.825 & 4 & 1250 & 0.795 & 4 & 1319 & 0.846 & 1951 & 4 & 0.872 & 5 & 1915 & 0.745 \\
\hline 5 & 1368 & 0.802 & 5 & 1221 & 0.777 & 5 & 1315 & 0.843 & 1886 & 5 & 0.843 & 6 & 1796 & 0.699 \\
\hline 6 & 1325 & 0.776 & 6 & 1193 & 0.759 & 6 & 1311 & 0.841 & 1871 & 6 & 0.836 & 7 & 1727 & 0.672 \\
\hline 7 & 1381 & 0.809 & 7 & 1173 & 0.746 & 7 & 1304 & 0.836 & 1865 & 7 & 0.834 & 8 & 1929 & 0.750 \\
\hline 8 & 1454 & 0.851 & 8 & 1162 & 0.739 & 8 & 1300 & 0.834 & 1837 & 8 & 0.821 & 9 & 1984 & 0.772 \\
\hline 9 & 1334 & 0.781 & 9 & 1155 & 0.735 & 9 & 1297 & 0.832 & 1819 & 9 & 0.813 & 10 & 2204 & 0.858 \\
\hline 10 & 1326 & 0.777 & 10 & 1185 & 0.754 & 10 & 1329 & 0.852 & 1886 & 10 & 0.843 & 11 & 1960 & 0.763 \\
\hline 358 & 1 & 0.000 & 330 & 2 & 0.001 & 407 & 1 & 0.000 & 5 & 535 & 0.002 & 12 & 1794 & 0.698 \\
\hline & & & & & & & & & & & & 13 & 1769 & 0.688 \\
\hline & & & & & & & & & & & & 14 & 1732 & 0.674 \\
\hline & & & & & & & & & & & & 15 & 1859 & 0.723 \\
\hline & & & & & & & & & & & & 496 & 5 & 0.002 \\
\hline
\end{tabular}

${ }^{a}$ Time since BOC.

${ }^{b}$ Ratio of boron concentration relative to boron concentration at BOC. 


\section{COMPUTATIONAL ANALYSIS}

\subsection{COMPUTATIONAL METHODS}

The computational analysis of the measurements was carried out using the two-dimensional (2-D) depletion sequence TRITON in the SCALE computer code system (Ref. 10). For a consistent comparison of the calculated results against all measurement data in Table 1.1, the same methods and nuclear data were used in calculations, as available in version 5.1 of SCALE. TRITON couples the 2-D arbitrary polygonal mesh transport code NEWT with the depletion and decay code ORIGEN-S to perform the burnup simulation. At each depletion step, the transport flux solution from NEWT is used to generate cross sections for the ORIGEN-S calculation. The isotopic composition data resulting from ORIGEN-S are employed in the subsequent transport calculation to obtain cross sections for the next depletion step in an iterative manner throughout the irradiation history.

TRITON has the capability of individually simulating the depletion of multiple mixtures (e.g., fuel rods) in a fuel assembly model. This is a very useful and powerful feature in a nuclide inventory analysis as it allows a more accurate representation of the local flux distribution and neutronic environment of the specific measured fuel rod in the assembly. The flux normalization in a TRITON calculation can be performed using either the power in a specified mixture, the total power corresponding to multiple mixtures, or the assembly power. The first option permits the burnup (power) in the measured sample to be input, usually inferred from measurement data for burnup indicators (such as ${ }^{148} \mathrm{Nd}$ or ${ }^{137} \mathrm{Cs}$ ), rather than an assembly average value.

Individual TRITON models, to be presented in this section, were developed for each of the measured samples. All TRITON calculations employed the SCALE 44-group ENDF/B-V cross-section library and the NITAWL resonance cross-section processor. Default values were used for the convergence parameters in the NEWT transport calculation. At each depletion step, all 232 isotopes for which crosssection data are available in the SCALE 44-group library used with NEWT were applied in updating cross sections for the ORIGEN-S fuel depletion calculation based on the flux solution from the transport calculation with NEWT. Selected TRITON input files are provided in Appendix A.

\subsection{MODELS}

The analysis of the fuel samples was carried out by developing individual models for each of the considered samples. Given the location of the fuel rod from which each sample was selected, at the periphery of the fuel assembly during irradiation cycles 7 through 10 , the assembly adjacent to the assembly hosting that fuel rod was also included in the model. As shown in previous studies (Ref. 11), for fuel rods located at the edge of the assembly, a more accurate representation of the rod environment in the simulation model is desirable, as it has a significant effect on the calculated isotopic composition in the rod. During cycle 11, the measured fuel rods were located nearer the center of the fuel assembly; for this cycle the adjacent assembly was not included in the model because in this case the rod environment was mainly influenced by the configuration of the assembly in which the rod was located. The geometry, material, and burnup data used in the TRITON models are as listed in Tables 4.1-4.8. Individual depleting mixtures were specified for the measured rod and its adjacent nearest-neighbor fuel rods. All other fuel rods were treated as a single depletion material with uniform composition.

The simulation of the fuel irradiation for each sample took into account the change, from cycle to cycle, of the adjacent assembly data as well as the reconstitution of the assembly before cycle 11 . As previously noted, fuel rods WZR0058, WZtR165, and WZtR160 were removed from the fuel assembly in which they were irradiated during cycles 7 through 10 and inserted in a rebuilt assembly for irradiation during 
cycle 11. Taking advantage of the assembly symmetry, only one quarter of the assembly hosting the measured rod was included in the TRITON model. The illustrations of the TRITON models for each irradiation cycle for samples in fuel rod WZR0058 are shown in Figures 5.1-5.5. During cycle 10, assembly EC45, which hosted fuel rod WZR0058, was located at the edge of the core (see Figure 4.2 and Table 4.3); a layer of water was included in the model for this cycle, as illustrated in Figure 5.4. Note that during cycles 7 through 10, rod WZR0058 was located in the lower right quadrant of assembly EC45 (see Figure 4.1), while during cycle 11 it was located in the upper left quadrant of assembly EF05, as illustrated in Figures 5.1-5.5.

The fuel assemblies adjacent to assembly EC45 on the east side had different burnups at BOC-7 through BOC-10, as shown in Table 4.3. The influence of the neighboring assemblies during each cycle was accounted for in the computational model. The nominal composition of the adjacent fuel assembly in each cycle was calculated to correspond to the operator-reported burnup at the BOC. During the burnup simulation the isotopic contents of the neighbor assembly were allowed to deplete. For example, assembly C12 that neighbored assembly EC45 at BOC-8, had an assembly average burnup of

$31.333 \mathrm{GWd} / \mathrm{MTU}$. Assuming that the burnup distribution on the axial direction for assembly C12 was the same as the available burnup distribution on the axial direction for rod WZR0058, the burnup at the axial location $z_{s}$ (corresponding to axial location $z$ of sample $s$ in rod WZR0058) in assembly C12, $B_{C 12}^{z_{s}}$, was calculated as

$$
B_{C 12}^{z_{s}}=\overline{B_{C 12}} \frac{B_{W Z R 0058}^{s}}{\overline{B_{W Z R 0058}}}
$$

where $\overline{B_{C 12}}$ is the assembly average burnup at BOC-11 for assembly C12, $\overline{B_{W Z R 0058}}$ is the average burnup of fuel rod WZR0058, and $B_{W Z R 0058}^{s}$ is the burnup of sample $s$ selected from rod WZR0058 at axial location $z_{s}$. Separate TRITON simulations of assembly C12 were performed to determine its fuel composition at BOC-8 corresponding to the burnup values calculated as in Eq. (5.1).

At the end of the TRITON simulation for each cycle from 7 through 10, the composition of all fuel mixtures in the assembly hosting the measured rod was extracted and used as input data in the TRITON model for the subsequent irradiation cycle. Therefore, there were five TRITON simulations (five models) for each of the samples considered. The variation of the boron concentration in the moderator was included in the TRITON models through the use of the TIMETABLE record in the input files. The composition at BOC-11 of the fuel in rebuilt assembly EF05, other than the fuel in measured fuel rods, was calculated based on the provided assembly burnup of $26.5 \mathrm{GWd} / \mathrm{MTU}$ at BOC-11 and initial enrichment of $4.240 \mathrm{wt} \%{ }^{235} \mathrm{U}$ in a manner similar to that discussed above for assembly C12 and expressed by Eq. (5.1).

An important parameter in the computational model is the value of the sample burnup used in the calculation. As the burnup estimated by the utility is generally not of sufficient accuracy to be used in benchmarks, the burnup based on the measured values of burnup indicators is widely used instead. The isotopes generally used as burnup indicators are fission products that are reliable measures of the integral number of fissions occurring in the fuel during irradiation. High-precision measurements of these nuclides are desirable to obtain a reliable measure of the sample burnup. 


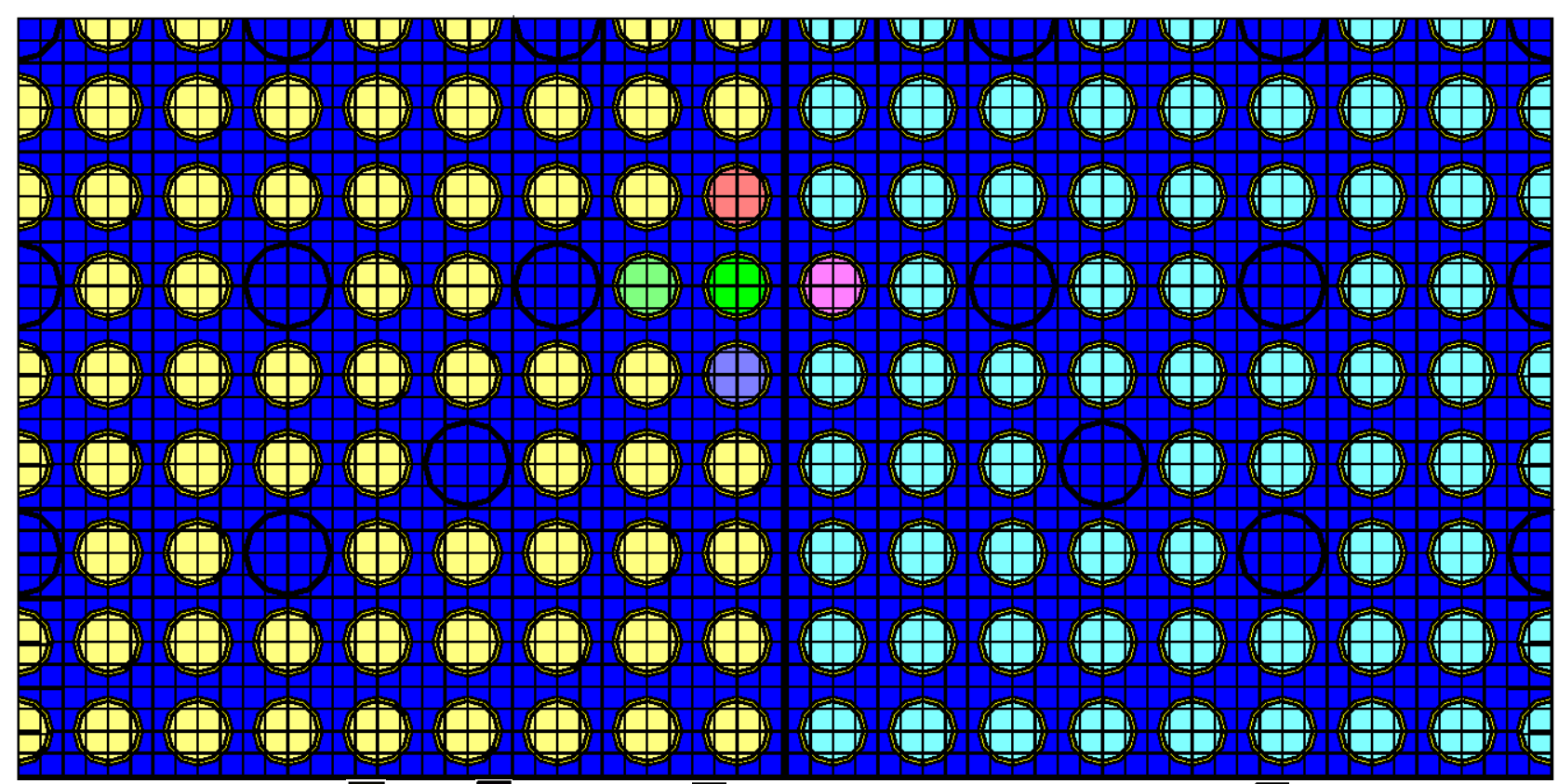

$\square$ test rod WZR0058 $\square$ clad $\square$ guide tube $\square$ test assembly EC45 $\square$ N test rod $\square$ s test rod $\square$ E test rod $\square$ w test rod $\square$ L4 assembly east of EC45

Figure 5.1. TRITON model for rod WZR0058 - cycle 7.

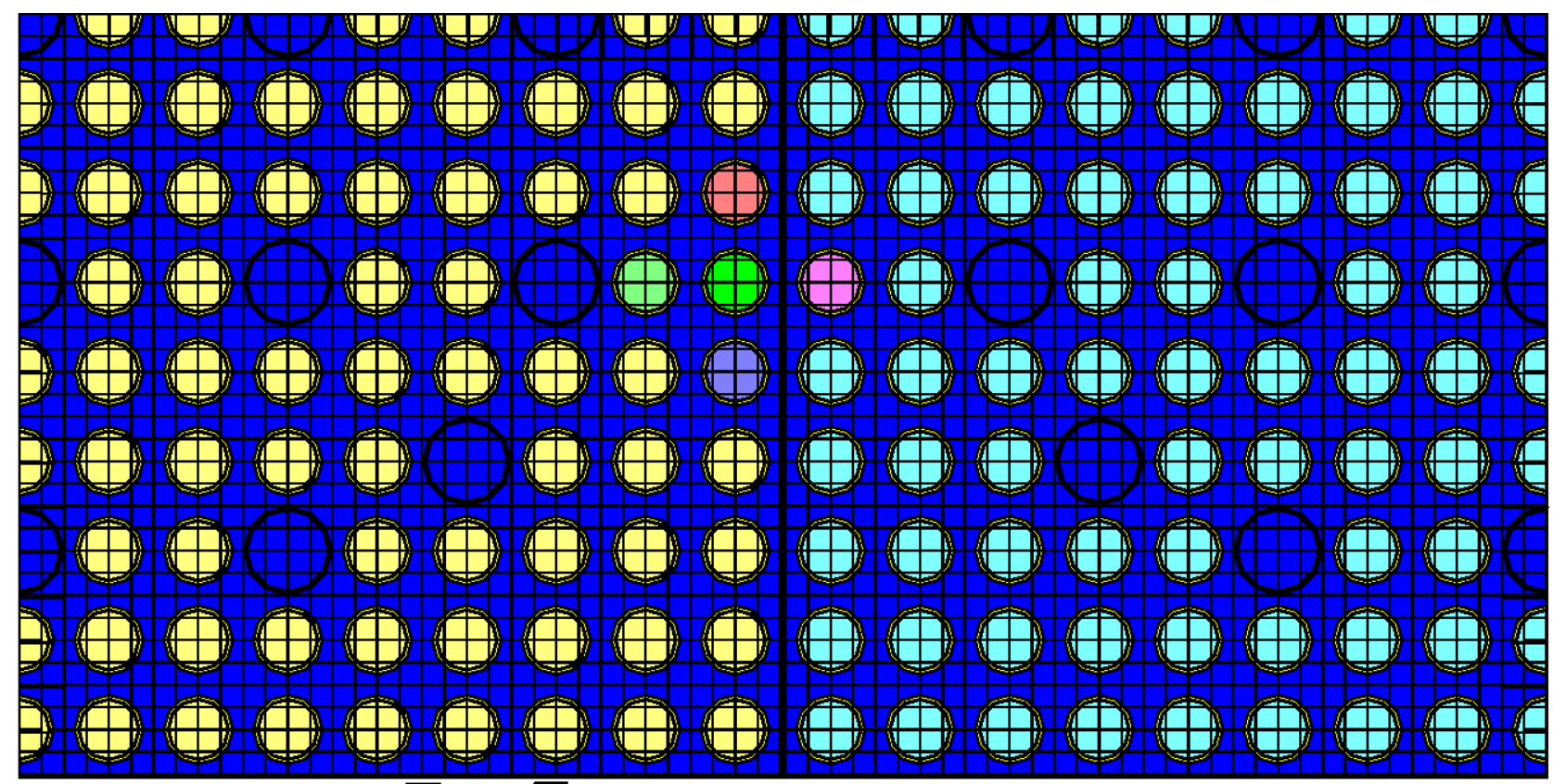

$\square$ test rod WZR0058 $\square$ clad $\square$ guide tube $\square$ assembly EC45 $\square$ N test rod $\square$ s test rod $\square \mathrm{E}$ test rod $\square \mathrm{W}$ test rod $\square$ L4 assembly east of EC45

Figure 5.2. TRITON model for rod WZR0058 - cycle 8. 


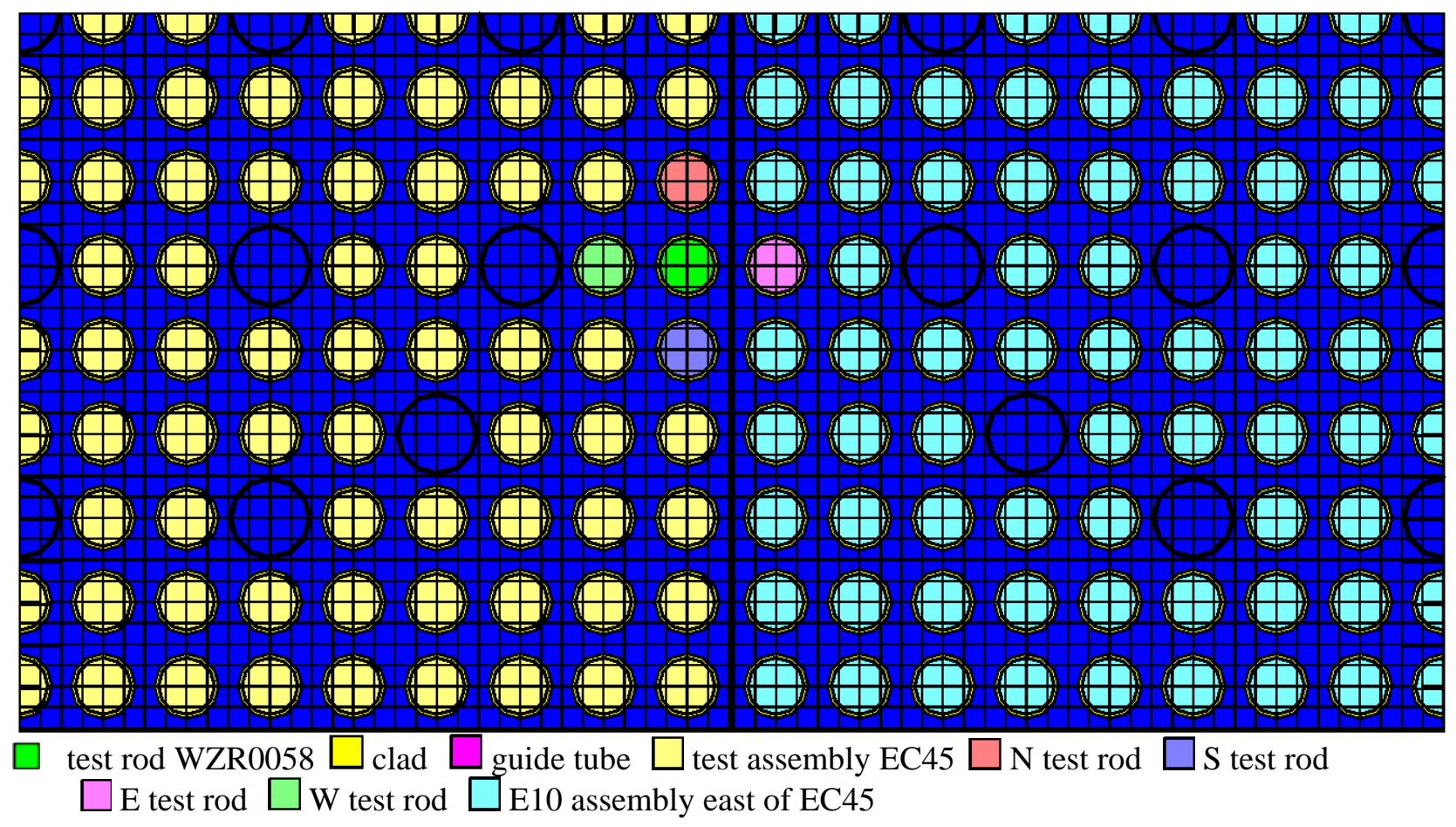

Figure 5.3. TRITON model for rod WZR0058 - cycle 9. 


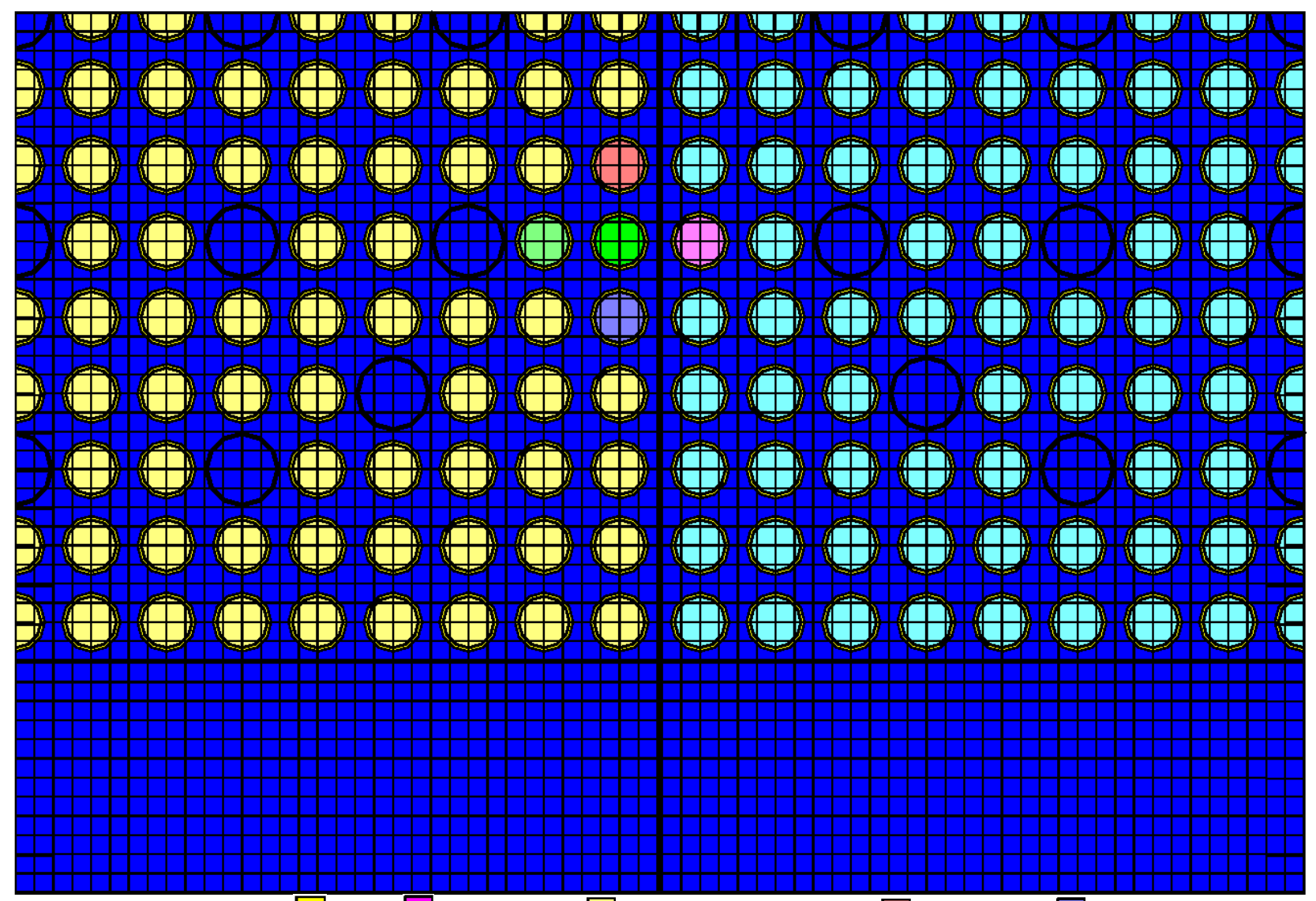

test rod WZR0058 $\square$ clad $\square$ guide tube $\square$ test assembly EC45 $\square$ N test rod $\square$ s test rod $\square$ E test rod $\square$ W test rod $\square$ G15 assembly east of EC45

Figure 5.4. TRITON model for rod WZR0058 - cycle 10. 


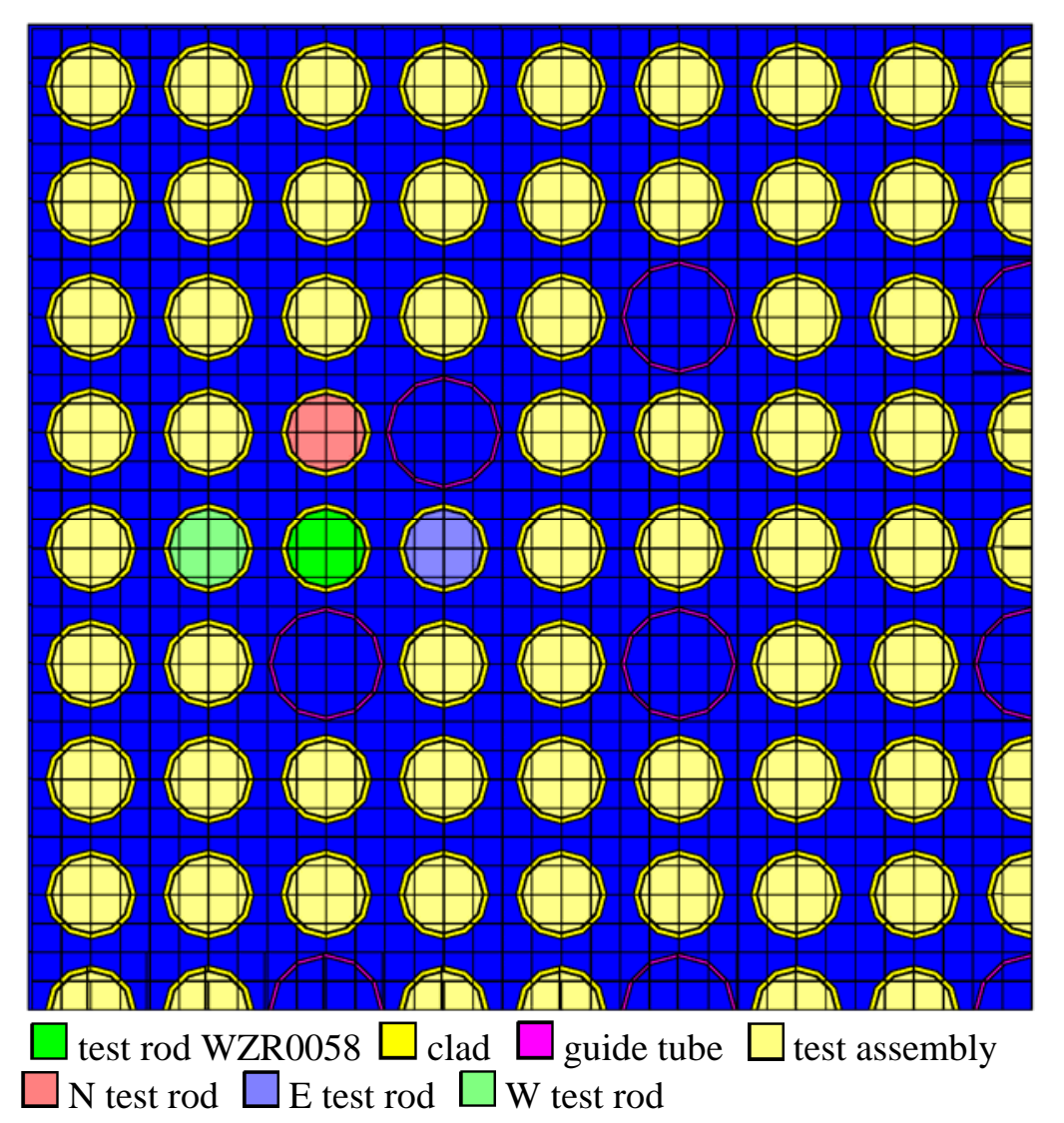

Figure 5.5. TRITON model for rod WZR0058 - cycle 11.

For the calculations in the current report, initial TRITON simulations were carried out for all samples using the burnup values provided in Table 4.6. Based on the results of these simulations, sample burnups were determined that reproduced the measured content of the burnup indicators fission products ${ }^{148} \mathrm{Nd}$ and ${ }^{137} \mathrm{Cs}$. A weighted average of the sample burnup $\bar{B}$ based on measured ${ }^{137} \mathrm{Cs}$ and ${ }^{148} \mathrm{Nd}$ content, with the measurement uncertainty used as a weighting function, was calculated as

$$
\bar{B}=\frac{\sum_{i=1}^{2}\left(B_{i} / \sigma_{i}^{2}\right)}{\sum_{i=1}^{2}\left(1 / \sigma_{i}^{2}\right)}
$$

where $B_{i}$ is the burnup calculated based on the measured burnup-indicating isotope $i$, and $\sigma_{i}$ is the measurement uncertainty for that isotope.

To assess the accuracy of measured data for the burnup indicators ${ }^{148} \mathrm{Nd}$ and ${ }^{137} \mathrm{Cs}$ for samples from rod WZR0058, the variation (see Figure 5.6) of the measured values for these two nuclides with the sample location along the length of fuel rod WZR0058 was investigated. Gamma scan measurement data for rod WZR0058 from measurements carried out in 2002 were available for ${ }^{137} \mathrm{Cs}$. The isotope ${ }^{148} \mathrm{Nd}$ was measured in 2003 for samples E58-88, E58-148, E58-263, E58-773, E58-793, and E58-796, and in 2007 for samples E58-257 and E58-793. The error bars shown in Figure 5.6 correspond to one standard deviation of the measurement uncertainty. 
As shown in Figure 5.6, the measured concentration for ${ }^{148} \mathrm{Nd}$ in sample E58-263, which was measured in the first campaign, was significantly different from the value for sample E58-257, which was measured in the second campaign. These two samples were cut from fuel segments adjacent to each other along the length of rod WZR0058 (26.3 and $25.7 \mathrm{~cm}$, respectively, from the bottom of the active fuel region) and were expected to have only slightly different burnups, as confirmed by the gamma scan. Moreover, as seen in Figure 5.6, the measured ${ }^{148} \mathrm{Nd}$ in sample E58-263 was similar to the measured content in samples located in the high-burnup region of the fuel rod, located $79 \mathrm{~cm}$ from the bottom of the active fuel region, in the flat profile burnup region (see Figure 2.1). Given the observed discrepancy in the measured ${ }^{148} \mathrm{Nd}$ data in the case of sample E58-263, the sample burnup for sample E58-260 (combined data for samples E58-263 and E58-257) was determined based on the measured content of ${ }^{137} \mathrm{Cs}$ and ${ }^{148} \mathrm{Nd}$ for E58-257 from the second campaign.

For the two samples, E58-88 and E58-700, for which measurement data were available from two campaigns, the ${ }^{148} \mathrm{Nd}$ and ${ }^{137} \mathrm{Cs}$ measured in the second campaign were used to calculate the sample burnup. This is due to the fact that the measurement methodologies for this later campaign were based on higher performance instruments (i.e., smaller measurement uncertainties) and improved measurement methods and standards. In addition, the burnups based on each of the measured fission products ${ }^{148} \mathrm{Nd}$ and ${ }^{137} \mathrm{Cs}$ in the second campaign were consistent. For sample 165-2a, measured in the first campaign only, the burnup was based on the measured ${ }^{137} \mathrm{Cs}$, as it was found that the burnup based on ${ }^{148} \mathrm{Nd}$ was inconsistent with the ${ }^{137} \mathrm{Cs}$ and was out of trend.

The derived sample burnups based on the measured ${ }^{148} \mathrm{Nd}$ and ${ }^{137} \mathrm{Cs}$ data are listed in Table 5.1. TRITON simulations based on these calculated sample burnups were carried out for the samples. The power values used in these simulations were slightly different than the data shown in Table 4.6, which were based on the operator burnup data. The power data corresponding to the measurement-based sample burnups were calculated by multiplying the power data shown in Table 4.6 by the ratio of the measurement-based sample burnup (see Table 5.1) and the initial estimate of sample burnup (see Table 4.6). The renormalized power data are presented in Table 5.1.

Table 5.1. Cycle power data based on measured sample burnups

\begin{tabular}{|l|c|r|r|r|r|r|}
\hline \multirow{2}{*}{ Sample ID } & \multirow{2}{*}{$\begin{array}{c}\text { Sample burnup } \\
\text { (GWd/MTU) }\end{array}$} & \multicolumn{5}{|c|}{$\begin{array}{c}\text { Sample cycle power } \\
\text { (MW/MTU) }\end{array}$} \\
\cline { 3 - 7 } & & Cycle 7 & Cycle 8 & Cycle 9 & Cycle 10 & Cycle 11 \\
\hline E58-88 & 42.489 & 30.277 & 16.800 & 26.937 & 6.985 & 22.994 \\
E58-148 & 54.820 & 39.064 & 21.676 & 34.754 & 9.013 & 29.667 \\
E58-260 & 64.624 & 46.051 & 25.552 & 40.971 & 10.625 & 34.973 \\
E58-700 & 77.013 & 54.879 & 30.451 & 48.824 & 12.661 & 41.677 \\
165-2a & 78.291 & 40.895 & 49.058 & 46.464 & 13.937 & 42.530 \\
160-800 & 70.921 & 38.974 & 46.754 & 44.223 & 6.283 & 40.683 \\
\hline
\end{tabular}




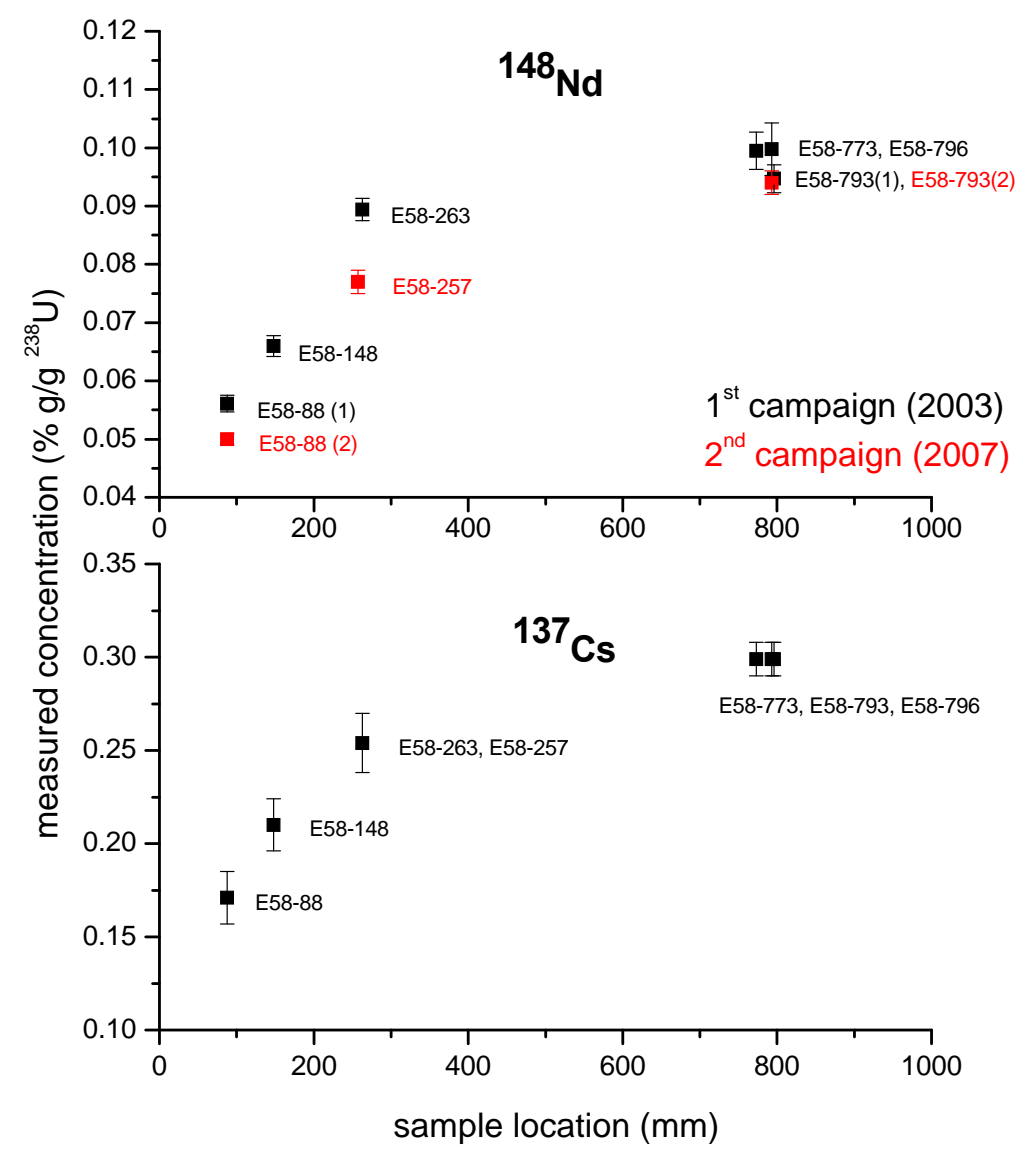

Figure 5.6. Measured data for ${ }^{148} \mathrm{Nd}$ and ${ }^{137}$ Cs vs. sample location for rod WZR0058.

Sample TRITON input files are provided in Appendix A for simulations corresponding to nominal burnups (power data as provided in Table 4.6) during cycles 7 through 11 for sample E58-88. As observed in the input files, the power values used in the depletion records of the TRITON inputs for cycles 8 through 11 were slightly different than the power values shown in Table 5.1. This is because the power in TRITON is normalized to the heavy metal mass of the measured fuel rod at the BOC of each simulation cycle, whereas the power data shown in Table 5.1 is expressed using the heavy metal mass in the measured fuel rod for fresh fuel before the irradiation as a basis. Because each cycle is modeled as a separate case, the TRITON user should recognize the fact that at the beginning of each simulation cycle the heavy metal mass in the measured rod changes slightly due to depletion. The user should renormalize the power to account for this. 


\section{RESULTS AND DISCUSSION}

The results of the comparison of the calculated nuclide concentrations with the measured data shown in Table 3.5 are listed in Table 6.1 and illustrated in Figures 6.1-6.44. The calculated nuclide concentrations correspond to the burnup values listed in Table 5.1. These burnup values were estimated based on measured data for the burnup indicators ${ }^{148} \mathrm{Nd}$ and ${ }^{137} \mathrm{Cs}$, as discussed in Sections 4 and 5 of this report. The comparison data in Table 6.1 include the calculated-to-experimental (C/E) nuclide concentration ratios in percentage. The average value shown in the final column of Table 6.1 represents a simple mean over the six samples of the C/E-1 value. The error bars shown in Figures 6.1-6.44 for the C/E-1 quantity include only the uncertainty on the measured data (E) corresponding to a $95 \%$ confidence level, as listed in Table 3.5.

The data for uranium nuclides are illustrated in Figures 6.1-6.3. The isotope ${ }^{235} \mathrm{U}$ was underestimated, on average by 5.5\%. Note that the samples considered in this study are in the high burnup range, a region in which the variation of ${ }^{235} \mathrm{U}$ content with burnup transitions from linear to exponential. This means that a small uncertainty in the sample burnup will significantly affect the calculated nuclide content. The isotopes ${ }^{234} \mathrm{U}$ and ${ }^{236} \mathrm{U}$ were calculated on average within about $10 \%$ and $4 \%$ of the measured data, respectively. The plutonium isotopes (see Figures 6.4-6.8) were all calculated on average within 6\% of the measurement for all plutonium isotopes measured. The major actinide ${ }^{239} \mathrm{Pu}$ is well estimated, within $6 \%$ of the measured data for each of the six samples, with an average deviation of $1.2 \%$.

The comparisons of the isotopic concentrations for the minor actinides are illustrated in Figures 6.9-6.13. The two measured americium isotopes, ${ }^{241} \mathrm{Am}$ and ${ }^{243} \mathrm{Am}$, are overestimated by an average of approximately $20-25 \%$. The curium isotope ${ }^{244} \mathrm{Cm}$ was highly overestimated, indicating possible issues with the measurements in this case. Note that the measurement errors for this isotope were large, between 20 and $45 \%$ at the $95 \%$ confidence level. The ${ }^{246} \mathrm{Cm}$ nuclide was overestimated by an average of approximately $15 \%$. The isotope ${ }^{237} \mathrm{~Np}$, of importance for burnup credit, was underestimated on average by approximately $5 \%$.

The cerium isotopes ${ }^{140} \mathrm{Ce}$ and ${ }^{142} \mathrm{Ce}$ (see Figures 6.14-6.15) were calculated on average between 1 and $2 \%$ of the measurement, respectively. The agreement was not as good for the other measured cerium nuclide ${ }^{144} \mathrm{Ce}$ (i.e., $22 \%$ on average), as seen in Figure 6.16. Note that the latter nuclide was measured by gamma scanning, with measurement uncertainties in the range of $10-50 \%$, as compared with the other cerium nuclides measured by IDA for which the experimental uncertainties were less than $6 \%$.

The results for cesium isotopes are illustrated in Figures 6.38-6.41. The isotope ${ }^{133} \mathrm{Cs}$, of importance to burnup credit, is calculated on average within $6 \%$ of the measured value, within the range of the measurement error. The isotope ${ }^{137} \mathrm{Cs}$ was calculated within $1.5 \%$ of the measurement. The isotopes ${ }^{134} \mathrm{Cs}$ and ${ }^{135} \mathrm{Cs}$ were consistently underestimated, on average by about $15 \%$ and $11 \%$, respectively. The underestimation of ${ }^{134} \mathrm{Cs}$ was consistent with data previously obtained with the 44-group ENDF/B-V SCALE cross-section library. As documented in Ref. 12, this is mainly due to deficiencies in the basic ENDF/B-V data, and improvements were observed when cross sections based on the most recent ENDF/B-VII evaluations were used.

The neodymium nuclides, except for ${ }^{142} \mathrm{Nd}$, were on average predicted within about $3 \%$ of the measurement, as illustrated in Figures 6.17-6.22.

The results for samarium nuclides are illustrated in Figures 6.23-6.29. The ${ }^{149} \mathrm{Sm}$ isotope, an important fission product for burnup credit criticality calculations, was overestimated on average by $14.3 \%$. The 
${ }^{147} \mathrm{Sm}$ and ${ }^{148} \mathrm{Sm}$ nuclides were on average predicted within 2.2 and $3.6 \%$, respectively, of the measurement, whereas ${ }^{151} \mathrm{Sm}$ and ${ }^{152} \mathrm{Sm}$ were consistently overestimated in the $30 \%$ range; ${ }^{150} \mathrm{Sm}$ and ${ }^{154} \mathrm{Sm}$ were overpredicted, on average by 4.8 and $8.5 \%$ compared to measurement. As shown previously (Ref. 12), the large differences for ${ }^{151} \mathrm{Sm}$ and ${ }^{152} \mathrm{Sm}$ were associated with cross-section data deficiencies, and significant improvements were seen when ENDF/B-VII cross sections were used.

The results for europium nuclides are shown in Figures 6.30-6.32. The nuclide ${ }^{153} \mathrm{Eu}$, important for burnup credit criticality calculations, was calculated on average within $3 \%$ of measurement. The ${ }^{154} \mathrm{Eu}$ isotope, an important gamma emitter, was overestimated by an average of $17 \%$. The ${ }^{155}$ Eu nuclide was underestimated by $22.4 \%$ on average.

The results for gadolinium nuclides are illustrated in Figures 6.33-6.37. The isotopes ${ }^{154} \mathrm{Gd}$ and ${ }^{158} \mathrm{Gd}$ were consistently overestimated in the $30 \%$ range. The isotopes ${ }^{156} \mathrm{Gd}$ and ${ }^{160} \mathrm{Gd}$ were calculated on average within about 3 and $5 \%$ of the measurement, respectively. The nuclide ${ }^{155} \mathrm{Gd}$, of importance to burnup credit, was underestimated by an average of approximately $8 \%$.

Results for ${ }^{106} \mathrm{Ru}$ are shown in Figure 6.42. This fission product was underestimated on average by approximately 6\%. The burnup-indicator fission product ${ }^{139} \mathrm{La}$ (see Figure 6.43) was consistently overestimated, on average by $8 \%$. Note that this nuclide was measured by a method (ICP-MS with external calibration) with larger inherent measurement uncertainties (17\%) than the ICP-MS with IDA method.

Two metallic fission products for which measurement data were available, ${ }^{99}$ Tc (see Figure 6.44) and ${ }^{103} \mathrm{Rh}$, both of importance to burnup credit criticality calculations, were overestimated by $5 \%$ and $8 \%$ on average, respectively. 
Table 6.1. C/E-1 (\%) results

\begin{tabular}{|c|c|c|c|c|c|c|c|}
\hline $\begin{array}{l}\text { Sample ID } \\
\text { Rod ID } \\
\text { Burnup (GWd/MTU) }\end{array}$ & $\begin{array}{c}\text { E58-88 } \\
\text { WZR0058 } \\
42.5\end{array}$ & $\begin{array}{c}\text { E58-148 } \\
\text { WZR0058 } \\
54.85\end{array}$ & $\begin{array}{c}\text { E58-260 } \\
\text { WZR0058 } \\
64.65\end{array}$ & $\begin{array}{c}\text { E58-700 } \\
\text { WZR0058 } \\
77.05\end{array}$ & $\begin{array}{c}165-2 a \\
\text { WZtR165 } \\
78.3\end{array}$ & $\begin{array}{c}160-800 \\
\text { WZtR160 } \\
70.9\end{array}$ & $\mathrm{AVG}^{a}$ \\
\hline U-234 & 3.9 & -6.1 & 18.9 & 14.3 & 16.9 & & 9.6 \\
\hline U-235 & -4.2 & -14.6 & -1.9 & -4.8 & -1.9 & & -5.5 \\
\hline U-236 & 8.7 & -1.3 & 3.0 & 5.6 & 3.3 & & 3.9 \\
\hline U-238 & -0.2 & -0.1 & -0.4 & -0.2 & 0.4 & & -0.1 \\
\hline Pu-238 & 0.3 & 20.4 & -3.4 & -2.2 & -7.6 & -9.1 & -0.3 \\
\hline Pu-239 & 0.9 & 4.4 & 2.3 & 2.9 & -6.0 & 2.9 & 1.2 \\
\hline Pu-240 & 8.3 & 12.1 & 6.6 & 6.6 & 0.2 & 0.0 & 5.6 \\
\hline Pu-241 & -0.9 & 5.6 & -0.6 & 0.9 & -7.2 & -4.3 & -1.1 \\
\hline Pu-242 & 8.8 & 17.8 & 6.2 & 5.7 & -1.7 & -4.2 & 5.4 \\
\hline Np-237 & -1.8 & -11.5 & -5.4 & 0.7 & -12.8 & -0.2 & -5.2 \\
\hline Am-241 & 23.8 & 29.9 & 19.0 & 23.5 & 10.8 & 19.7 & 21.1 \\
\hline Am-243 & 50.8 & 25.4 & 27.4 & 28.6 & -2.8 & 20.6 & 25.0 \\
\hline Cm-244 & 106.9 & 103.0 & 79.1 & 99.6 & 68.3 & 62.7 & 86.6 \\
\hline Cm-246 & -10.0 & 49.7 & 11.4 & 34.0 & 17.3 & -14.5 & 14.6 \\
\hline Cs-133 & 3.1 & 6.1 & -3.6 & 10.6 & 15.8 & & 6.4 \\
\hline Cs-134 & -25.1 & -14.3 & -15.8 & -11.2 & -11.8 & -12.6 & -15.1 \\
\hline Cs-135 & -10.8 & -15.1 & -20.5 & -2.2 & -7.5 & & -11.2 \\
\hline Cs-137 & -5.2 & 0.2 & -1.6 & 0.8 & -0.1 & -3.1 & -1.5 \\
\hline Ce-140 & 1.8 & 5.3 & -0.9 & 1.5 & 1.2 & -4.4 & 0.8 \\
\hline Ce-142 & -0.4 & -0.4 & -2.4 & -2.1 & -2.8 & -3.8 & -2.0 \\
\hline Ce-144 & 19.0 & 23.6 & 21.0 & 24.7 & 21.9 & & 22.0 \\
\hline Nd-142 & 25.3 & 34.0 & 21.9 & 17.2 & & 16.5 & 23.0 \\
\hline Nd-143 & -0.9 & 1.8 & 0.4 & 1.1 & 8.0 & 3.2 & 2.2 \\
\hline Nd-145 & 1.2 & 2.5 & 0.0 & -1.0 & 4.5 & 2.6 & 1.6 \\
\hline Nd-146 & 2.4 & 3.9 & 1.9 & 1.4 & 6.0 & 2.7 & 3.0 \\
\hline Nd-148 & 0.4 & -0.5 & 1.3 & -2.3 & -6.8 & 1.7 & -1.0 \\
\hline Nd-150 & -0.4 & 8.0 & -0.5 & 6.7 & -6.2 & 0.9 & 1.4 \\
\hline Sm-147 & -2.1 & -1.5 & 4.0 & -0.6 & -10.7 & & -2.2 \\
\hline Sm-148 & 3.8 & 2.5 & 0.7 & -4.1 & -12.3 & -12.2 & -3.6 \\
\hline Sm-149 & -0.1 & 0.9 & 12.5 & 26.6 & 29.9 & 16.2 & 14.3 \\
\hline Sm-150 & 5.3 & 3.8 & 6.1 & 5.5 & 9.4 & -1.6 & 4.8 \\
\hline Sm-151 & 23.8 & 36.9 & 38.8 & 32.7 & 37.1 & 30.2 & 33.3 \\
\hline Sm-152 & 26.7 & 30.9 & 34.2 & 35.4 & 30.7 & 28.5 & 31.1 \\
\hline Sm-154 & 6.4 & 17.9 & 22.8 & 13.7 & -4.5 & -5.2 & 8.5 \\
\hline Eu-153 & -7.1 & -3.3 & -4.0 & 2.1 & -0.5 & & -2.6 \\
\hline Eu-154 & 5.6 & 11.2 & 18.8 & 43.1 & 8.0 & & 17.3 \\
\hline Eu-155 & -24.8 & -29.2 & -26.0 & -16.3 & -15.6 & & -22.4 \\
\hline
\end{tabular}


Table 6.1 C/E-1 (\%) results (cont.)

\begin{tabular}{|c|c|c|c|c|c|c|c|}
\hline $\begin{array}{l}\text { Sample ID } \\
\text { Rod ID } \\
\text { Burnup (GWd/MTU) }\end{array}$ & $\begin{array}{c}\text { E58-88 } \\
\text { WZR0058 } \\
42.489\end{array}$ & $\begin{array}{c}\text { E58-148 } \\
\text { WZR0058 } \\
54.820\end{array}$ & $\begin{array}{c}\text { E58-263 } \\
\text { WZR0058 } \\
64.624 \\
\end{array}$ & $\begin{array}{c}\text { E58-700 } \\
\text { WZR0058 } \\
77.013 \\
\end{array}$ & $\begin{array}{c}165-2 a \\
\text { WZtR165 } \\
80.466 \\
\end{array}$ & $\begin{array}{c}160-800 \\
\text { WZtR160 } \\
70.921 \\
\end{array}$ & $\mathbf{A V G}^{a}$ \\
\hline Gd-154 & 41.3 & 24.4 & 51.8 & 37.7 & 10.5 & 35.5 & 33.5 \\
\hline Gd-155 & -9.3 & -17.1 & -7.4 & -11.8 & 6.9 & & -7.8 \\
\hline Gd-156 & 9.1 & 5.6 & 6.3 & 2.7 & 2.9 & -8.6 & 3.0 \\
\hline Gd-158 & 27.4 & 29.6 & 39.0 & 40.7 & 40.0 & 25.4 & 33.7 \\
\hline Gd-160 & -6.5 & 10.8 & 13.7 & 15.2 & -0.8 & -2.6 & 5.0 \\
\hline $\mathrm{Ru}-106$ & -17.3 & -6.3 & -6.5 & -0.5 & 1.4 & & -5.8 \\
\hline La-139 & 5.6 & & 11.4 & 6.3 & & 8.1 & 7.8 \\
\hline Rh-103 & & & & & & 8.0 & 8.0 \\
\hline Tc-99 & 6.9 & & & & & 2.9 & 4.9 \\
\hline
\end{tabular}

Simple mean (not weighted) of C/E-1 (\%). 


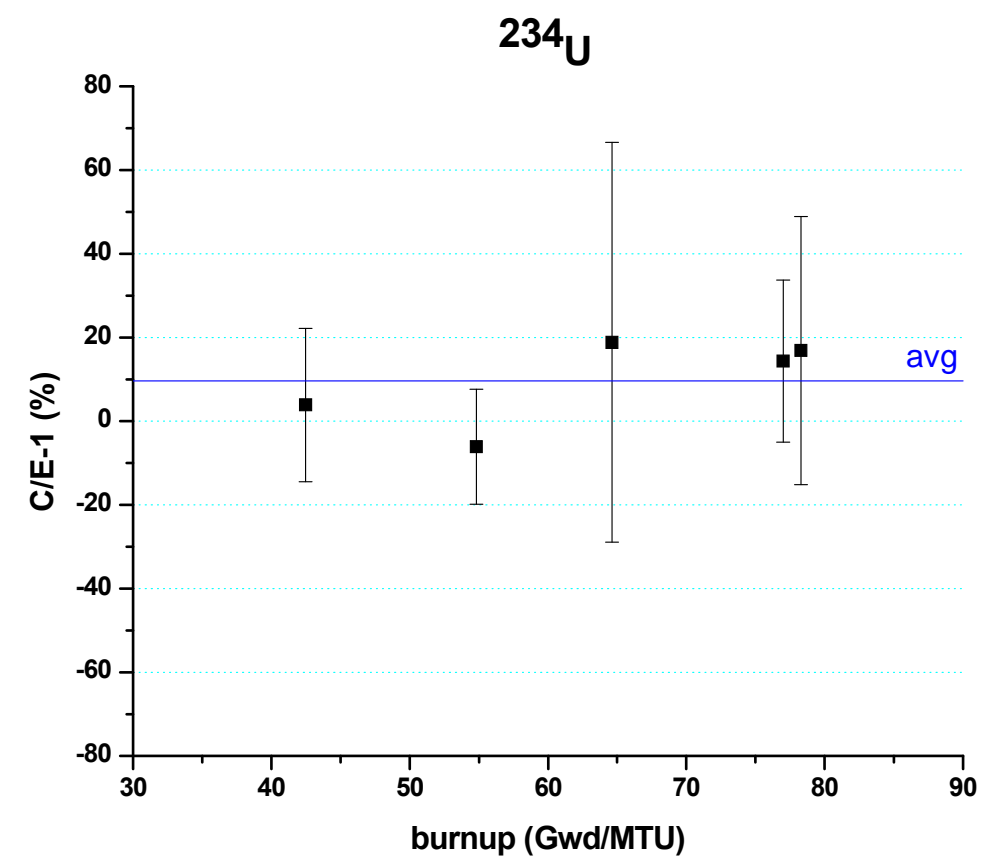

Figure 6.1. Calculation-to-measurement comparison for ${ }^{234} U$.

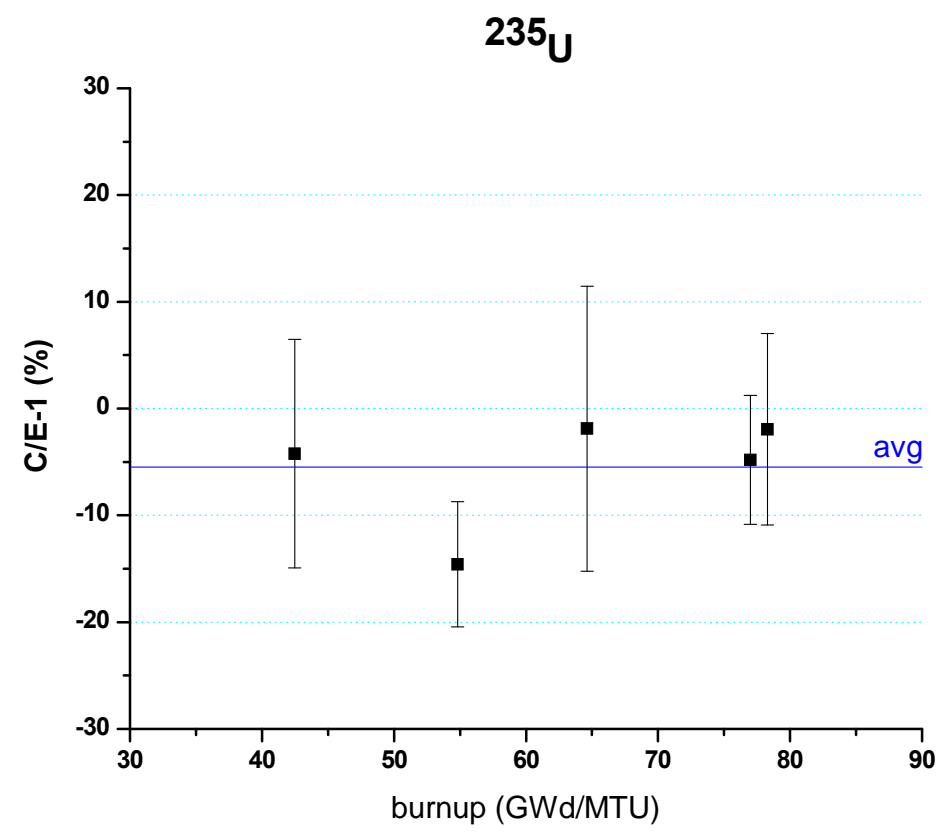

Figure 6.2. Calculation-to-measurement comparison for ${ }^{235} \mathrm{U}$. 


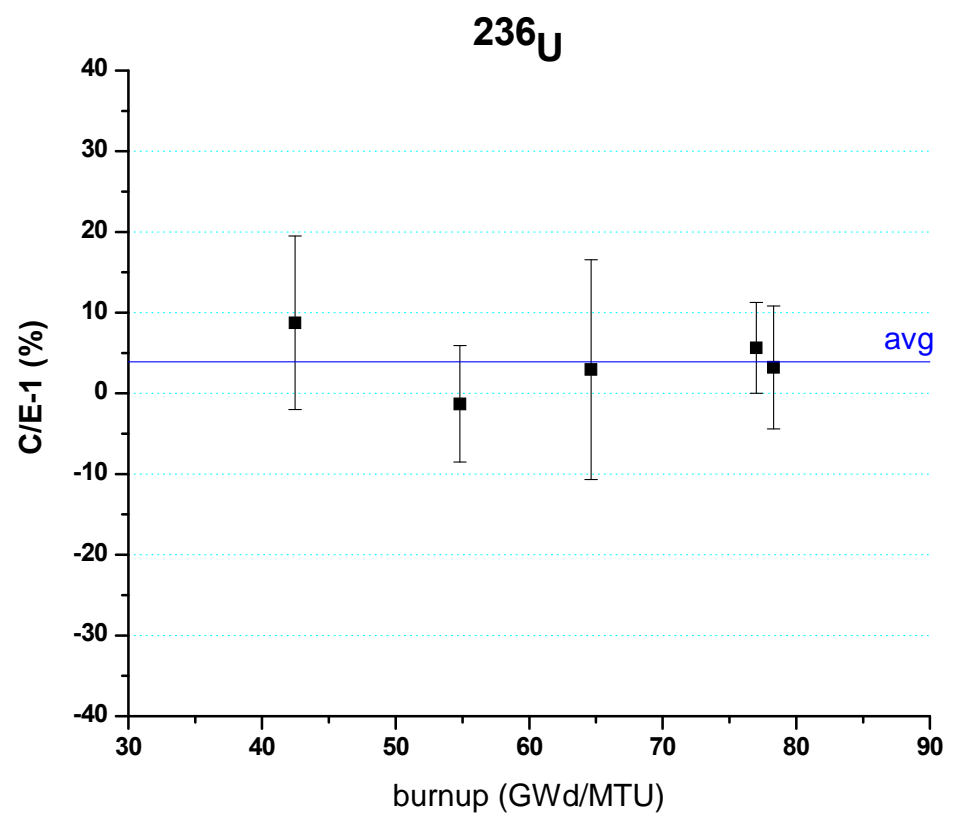

Figure 6.3. Calculation-to-measurement comparison for ${ }^{236} U$.

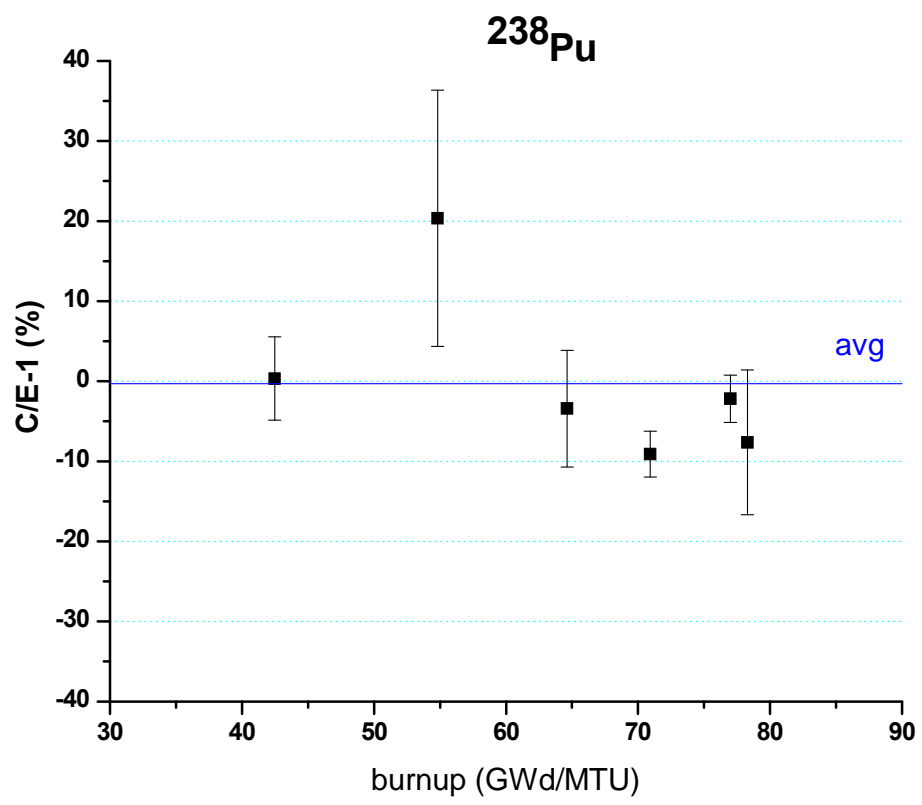

Figure 6.4. Calculation-to-measurement comparison for ${ }^{238} \mathrm{Pu}$. 


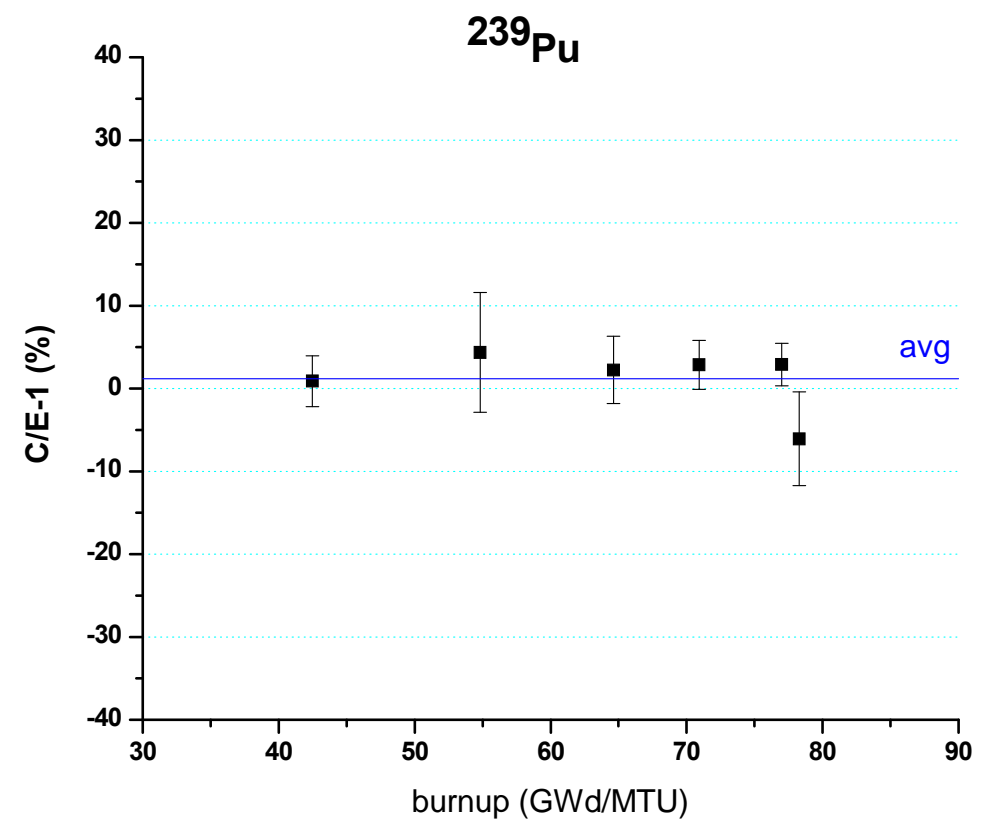

Figure 6.5. Calculation-to-measurement comparison for ${ }^{239} \mathrm{Pu}$.

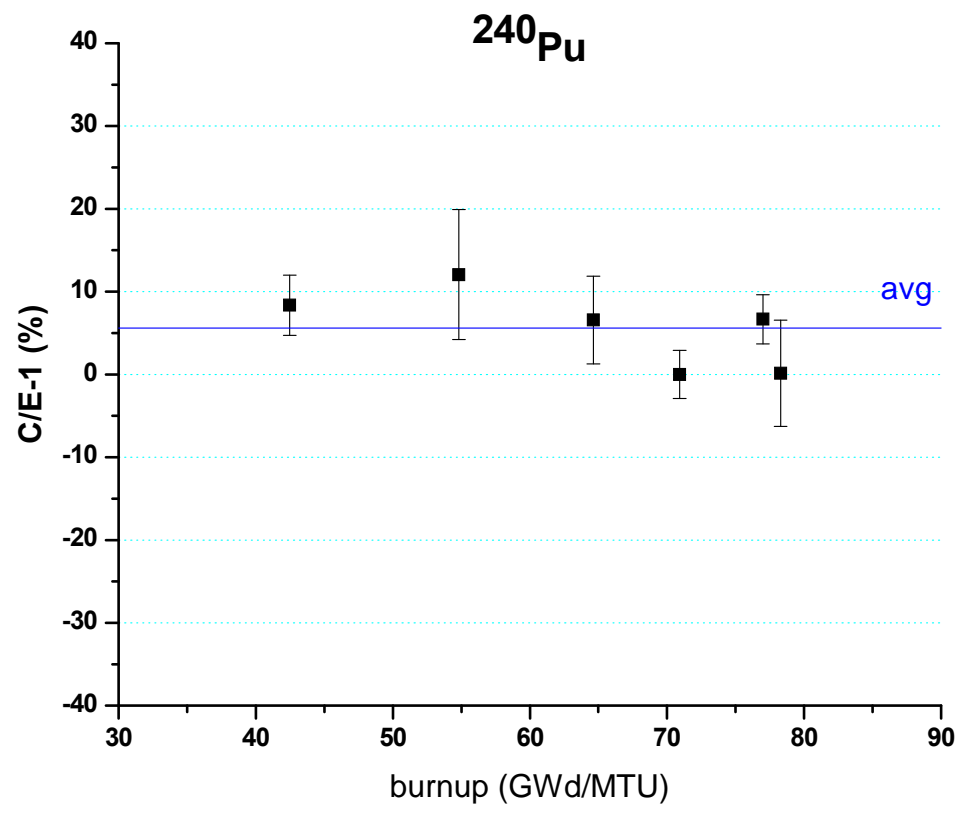

Figure 6.6. Calculation-to-measurement comparison for ${ }^{240} \mathrm{Pu}$. 


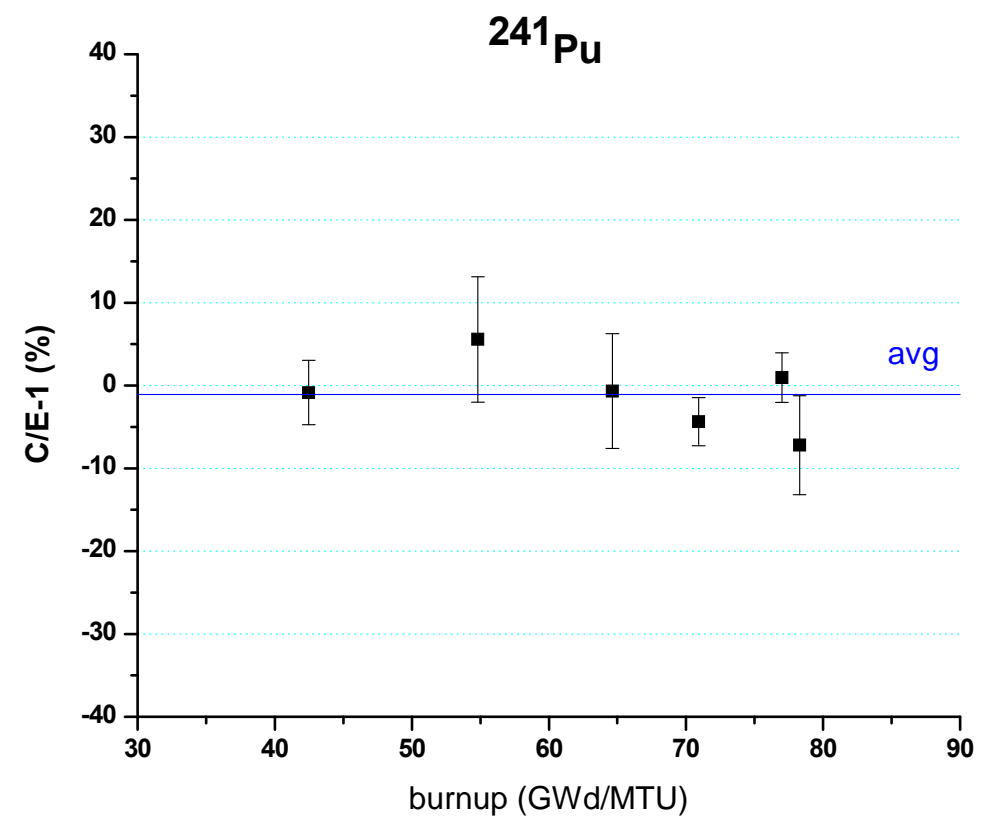

Figure 6.7. Calculation-to-measurement comparison for ${ }^{241} \mathrm{Pu}$.

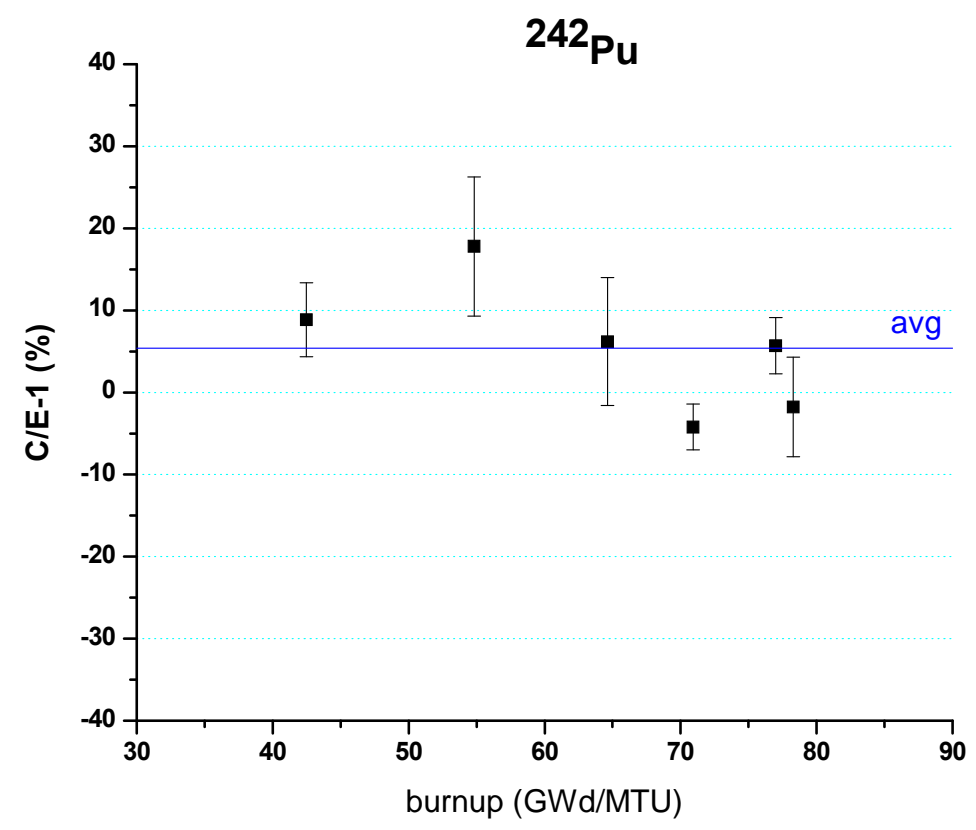

Figure 6.8. Calculation-to-measurement comparison for ${ }^{242} \mathrm{Pu}$. 


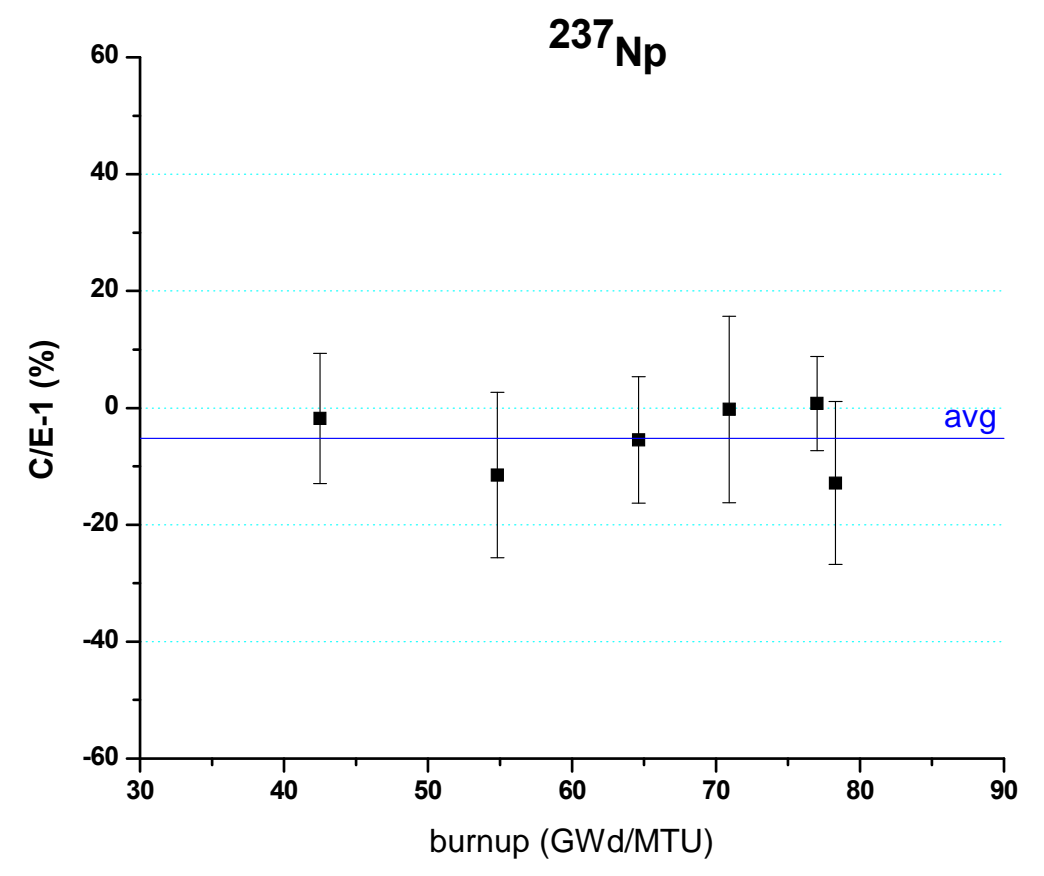

Figure 6.9. Calculation-to-measurement comparison for ${ }^{237} \mathrm{~Np}$.

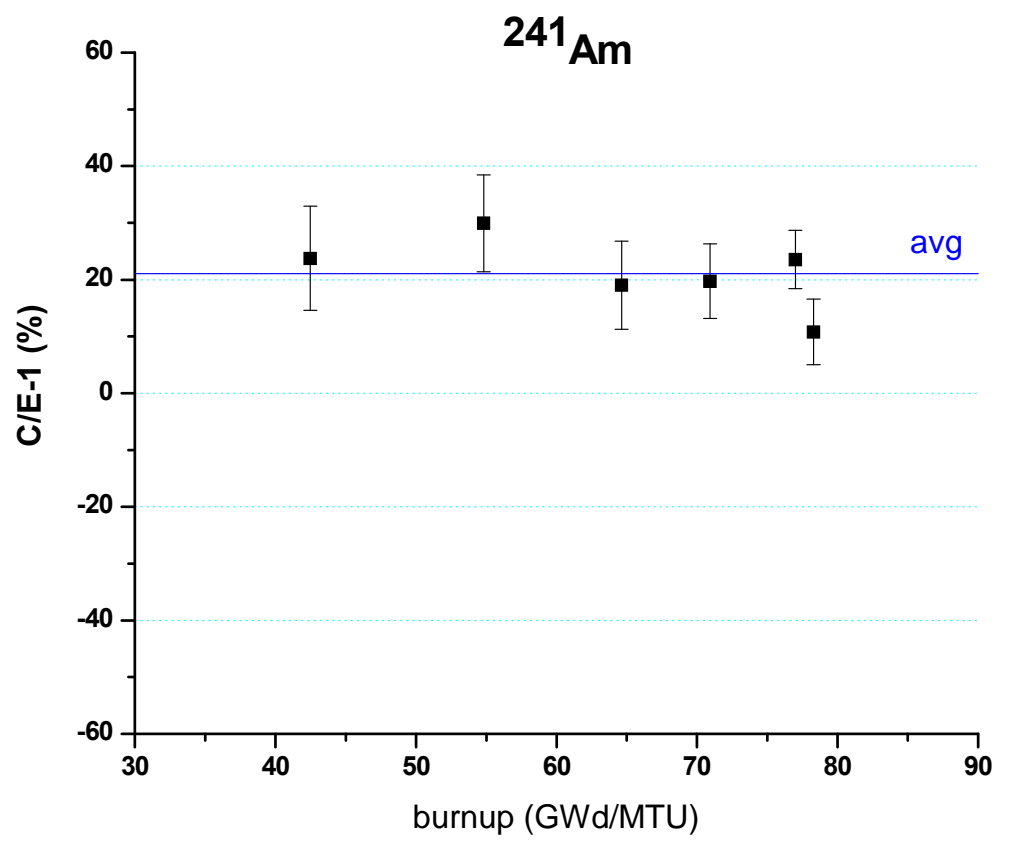

Figure 6.10. Calculation-to-measurement comparison for ${ }^{241} \mathrm{Am}$. 


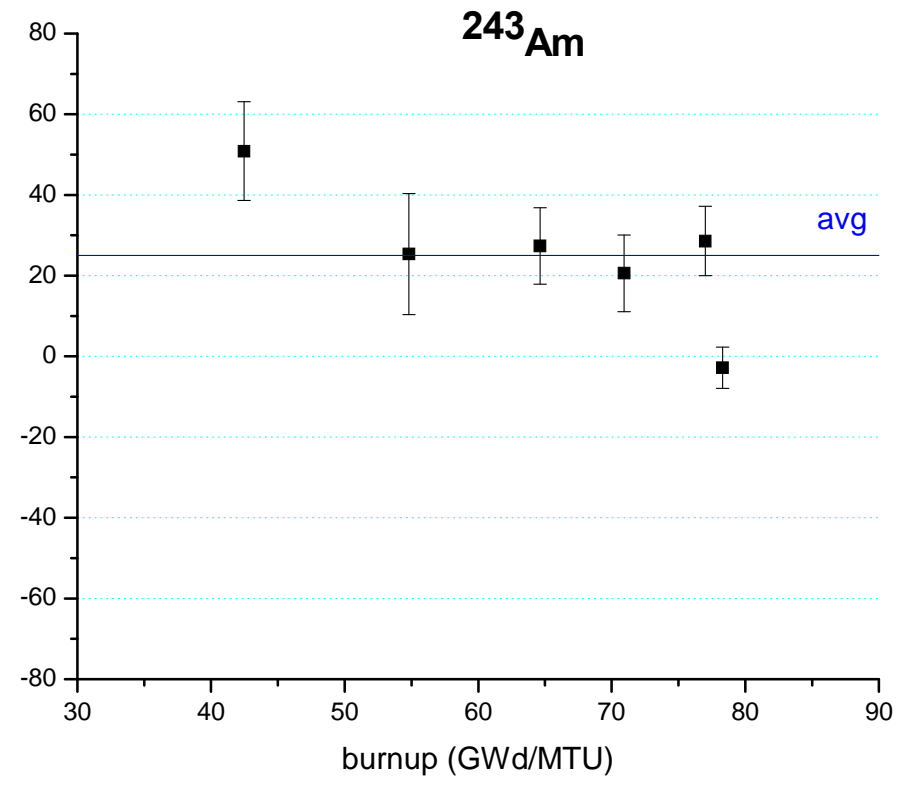

Figure 6.11. Calculation-to-measurement comparison for ${ }^{243} \mathrm{Am}$.

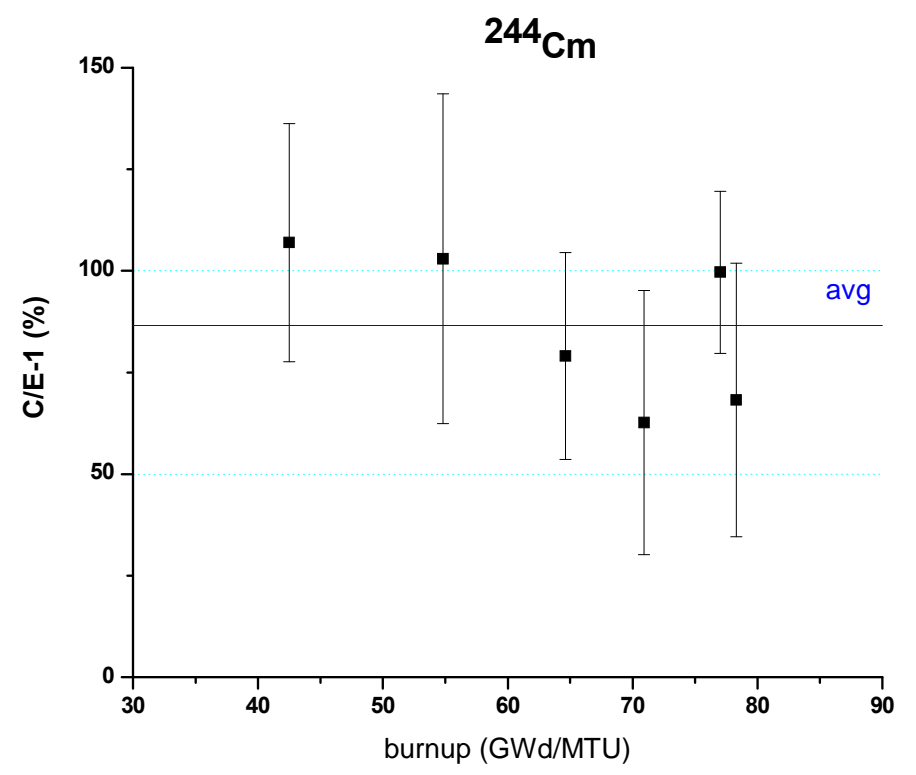

Figure 6.12. Calculation-to-measurement comparison for ${ }^{244} \mathrm{Cm}$ 


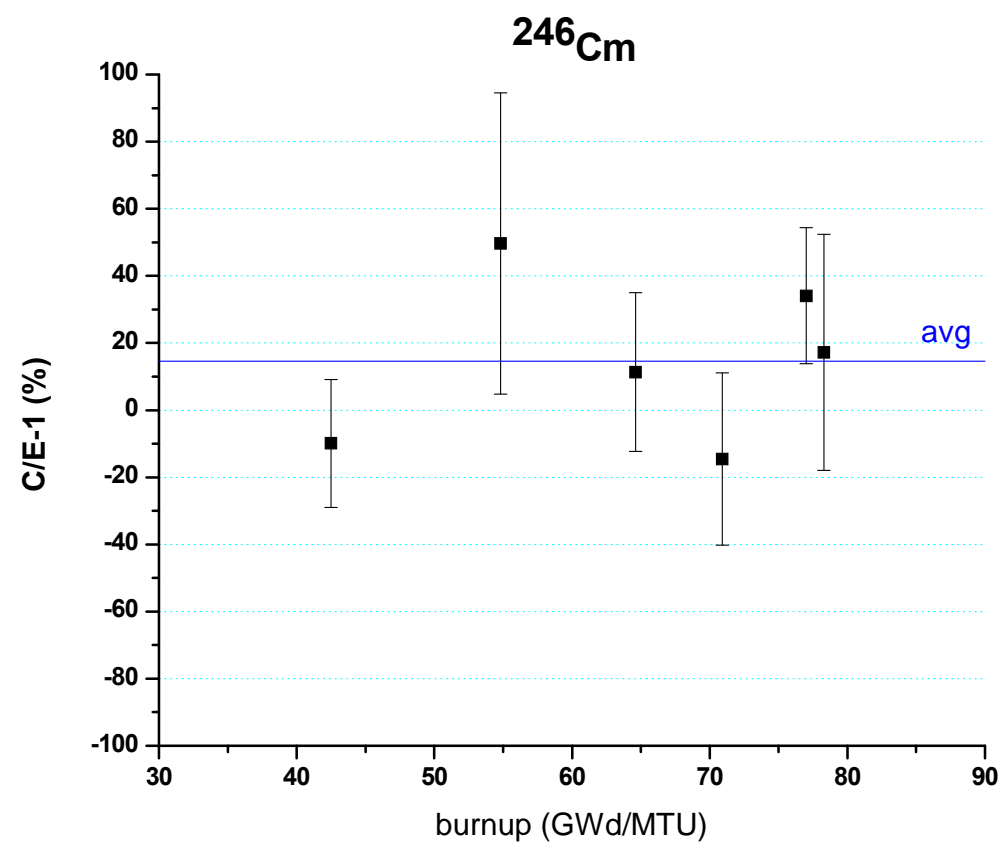

Figure 6.13. Calculation-to-measurement comparison for ${ }^{246} \mathrm{Cm}$

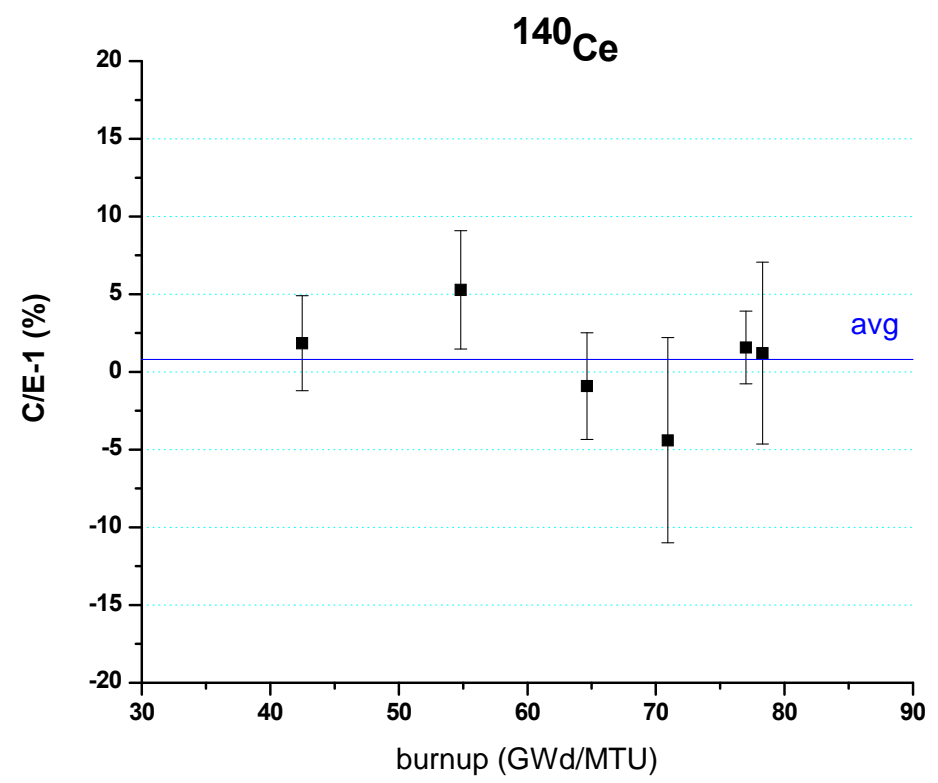

Figure 6.14. Calculation-to-measurement comparison for ${ }^{140} \mathrm{Ce}$. 


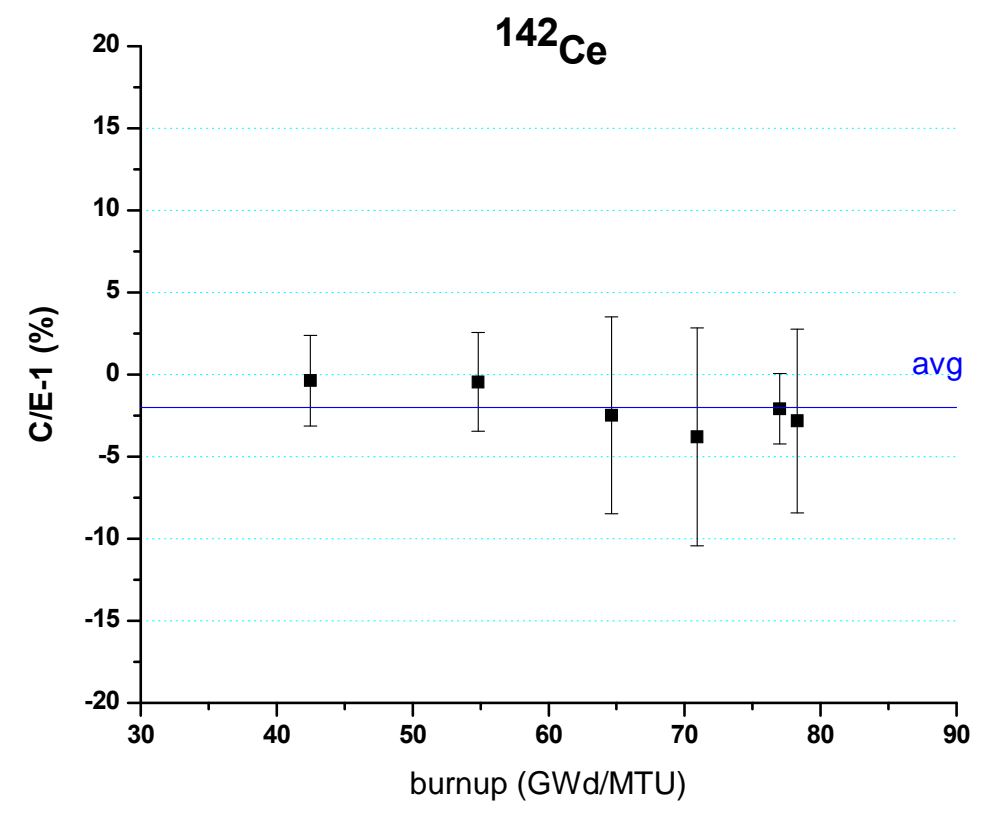

Figure 6.15. Calculation-to-measurement comparison for ${ }^{142} \mathrm{Ce}$.

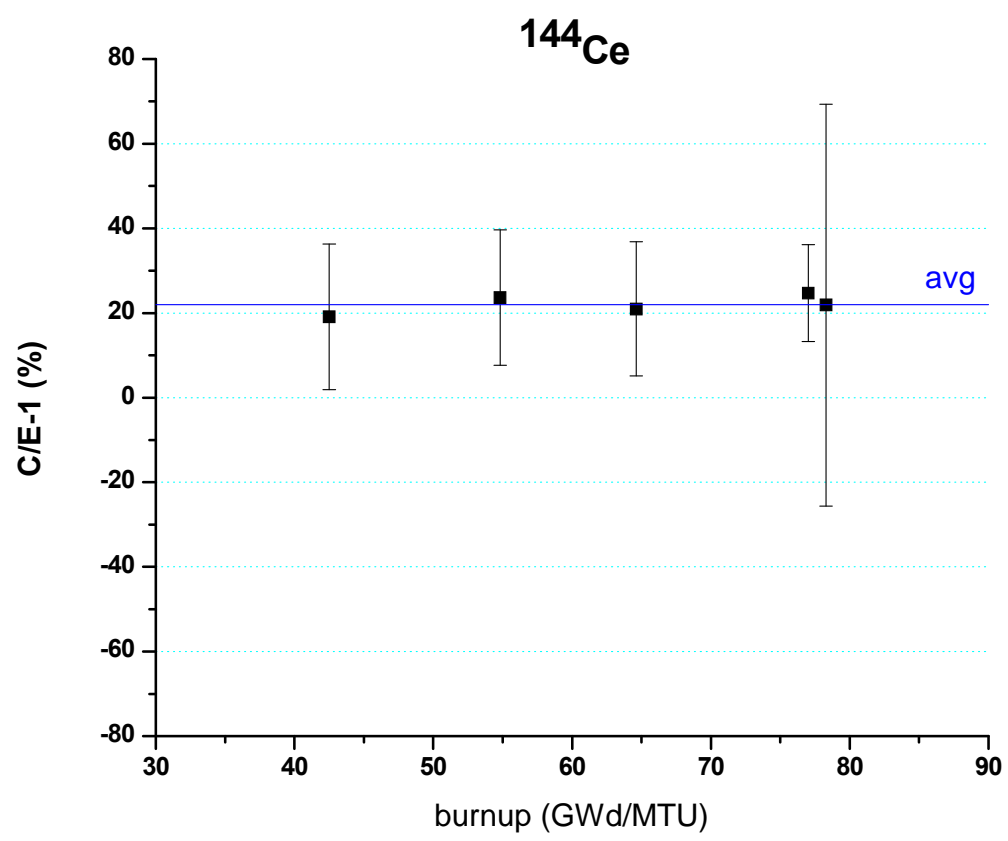

Figure 6.16. Calculation-to-measurement comparison for ${ }^{144} \mathrm{Ce}$. 


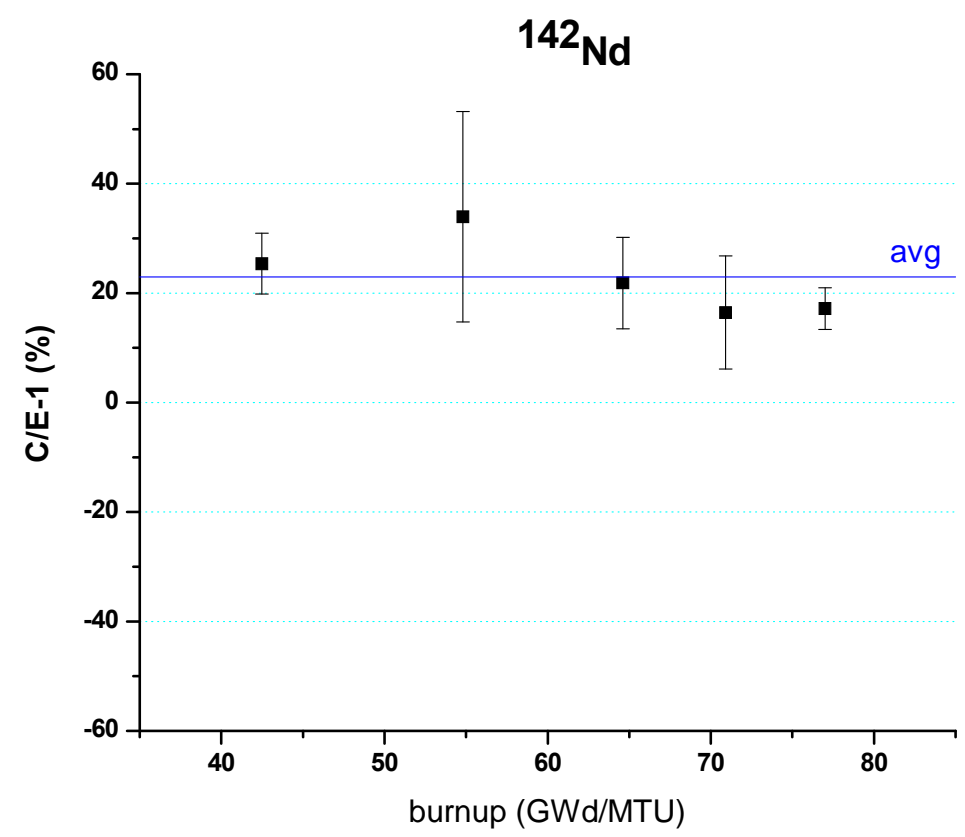

Figure 6.17. Calculation-to-measurement comparison for ${ }^{142} \mathrm{Nd}$.

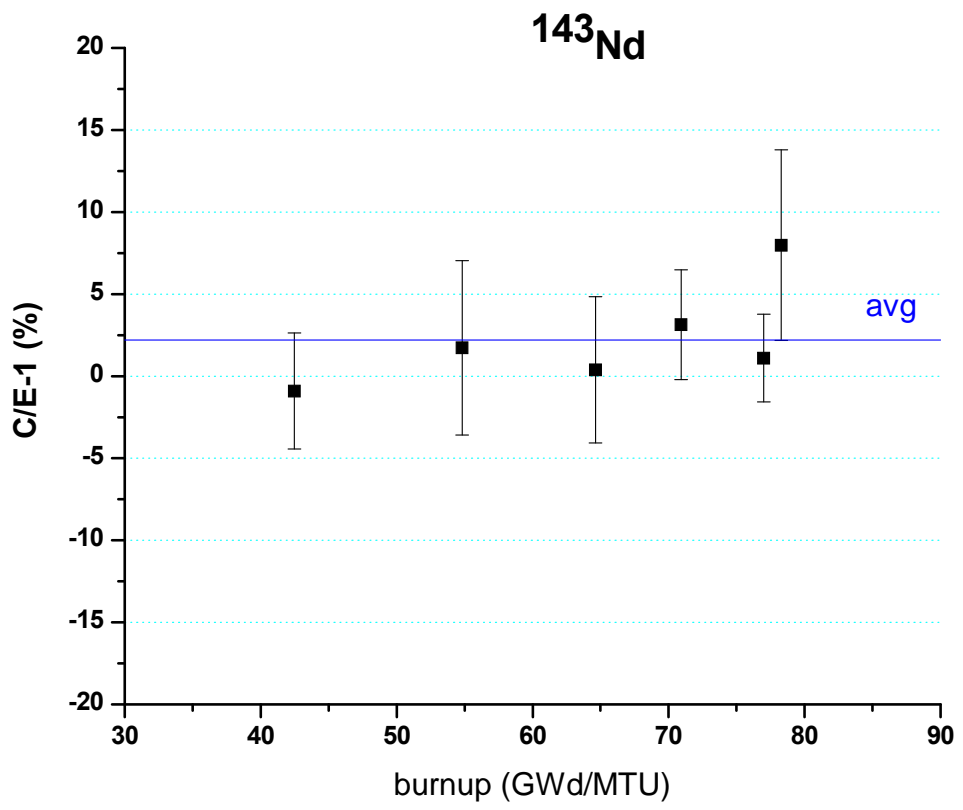

Figure 6.18. Calculation-to-measurement comparison for ${ }^{143} \mathrm{Nd}$. 


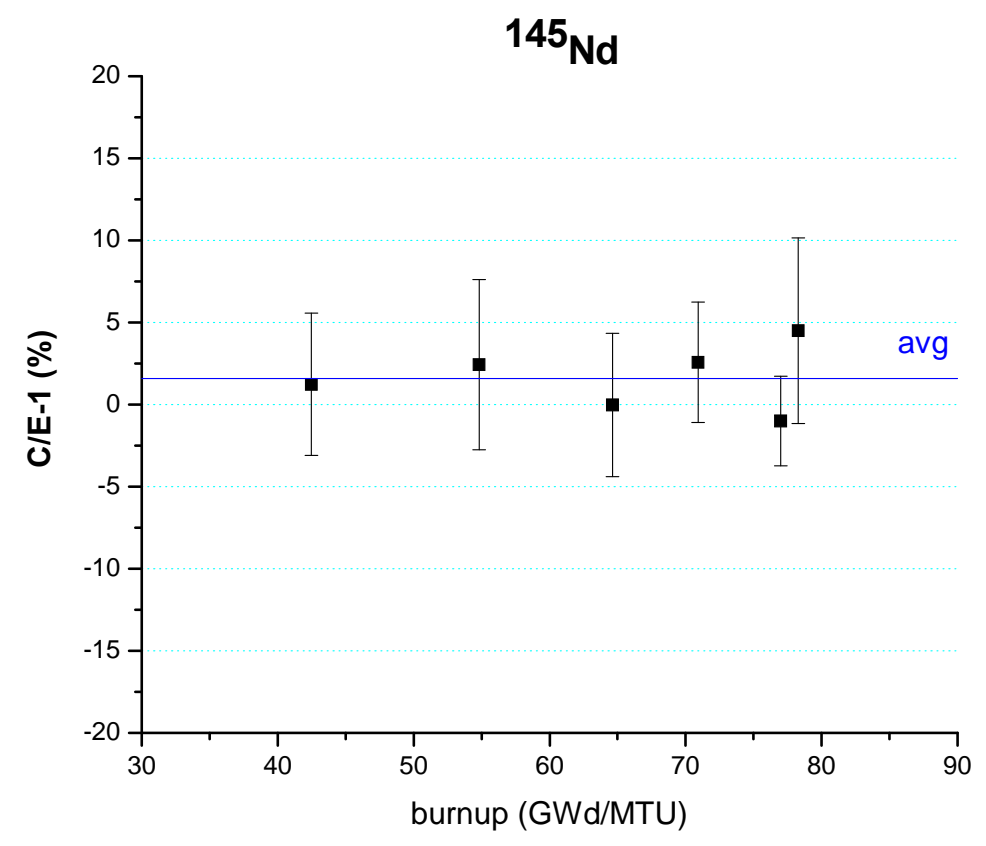

Figure 6.19. Calculation-to-measurement comparison for ${ }^{145} \mathrm{Nd}$.

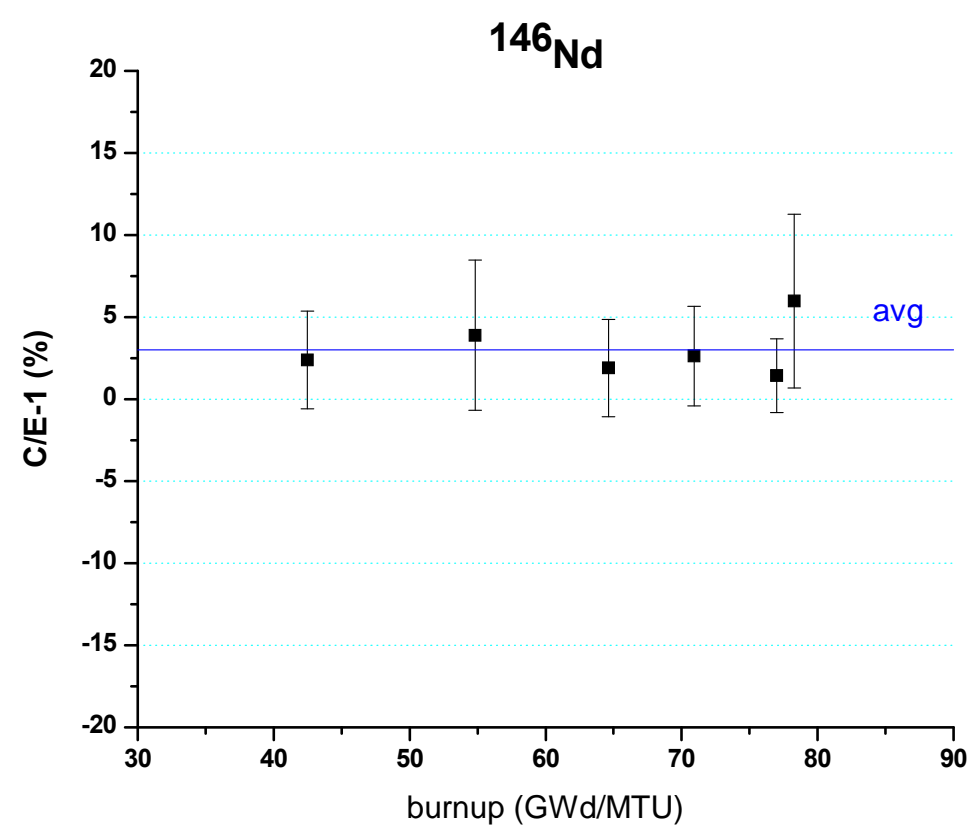

Figure 6.20. Calculation-to-measurement comparison for ${ }^{146} \mathrm{Nd}$. 


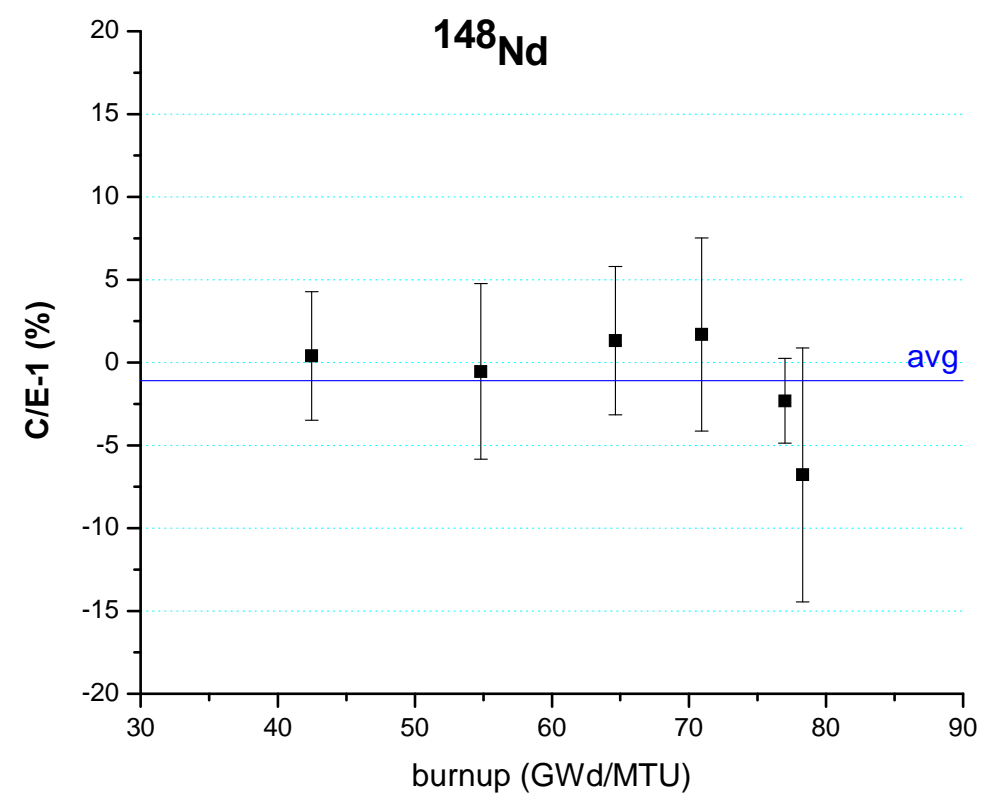

Figure 6.21. Calculation-to-measurement comparison for ${ }^{148} \mathrm{Nd}$.

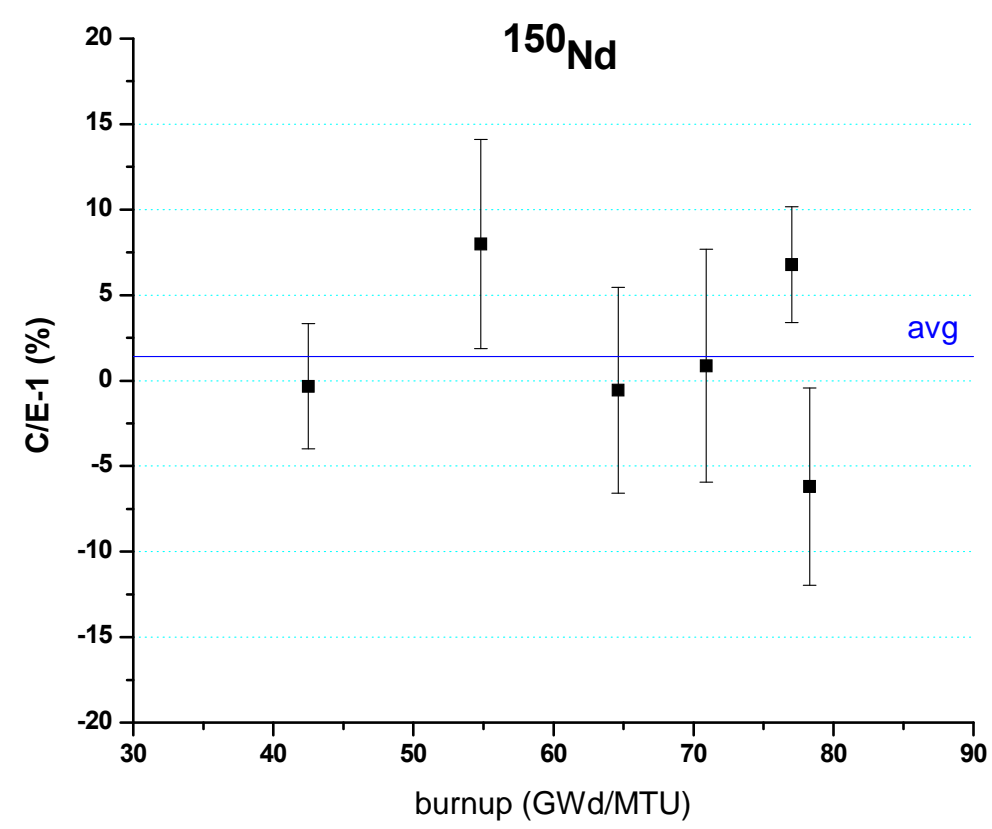

Figure 6.22. Calculation-to-measurement comparison for ${ }^{150} \mathrm{Nd}$. 
${ }^{147} \mathrm{Sm}$

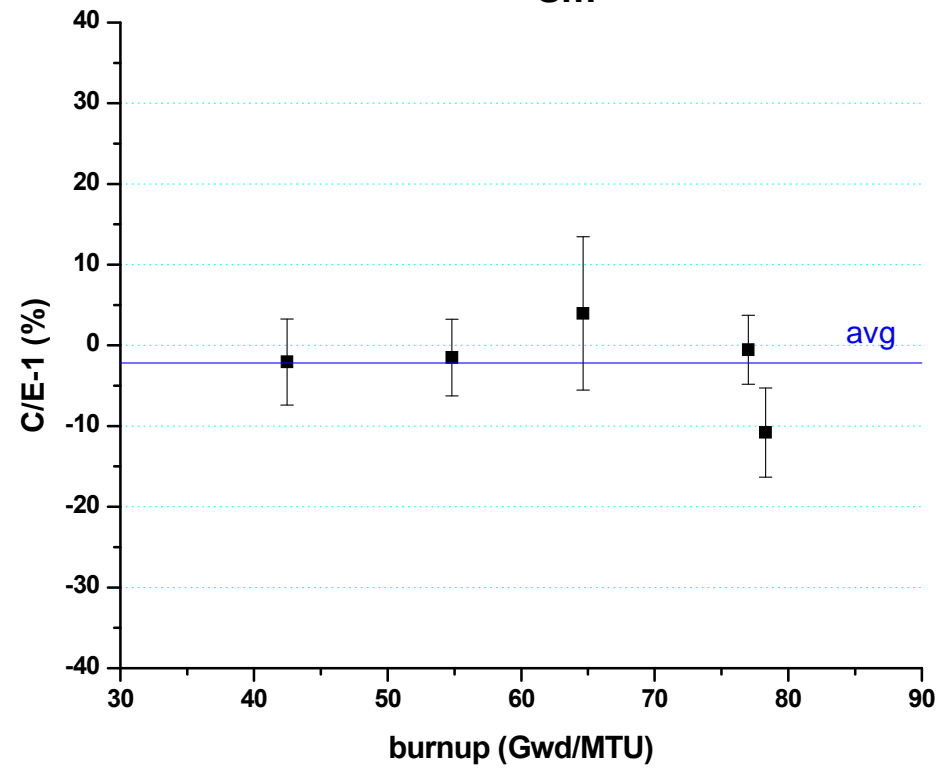

Figure 6.23. Calculation-to-measurement comparison for ${ }^{147} \mathrm{Sm}$.

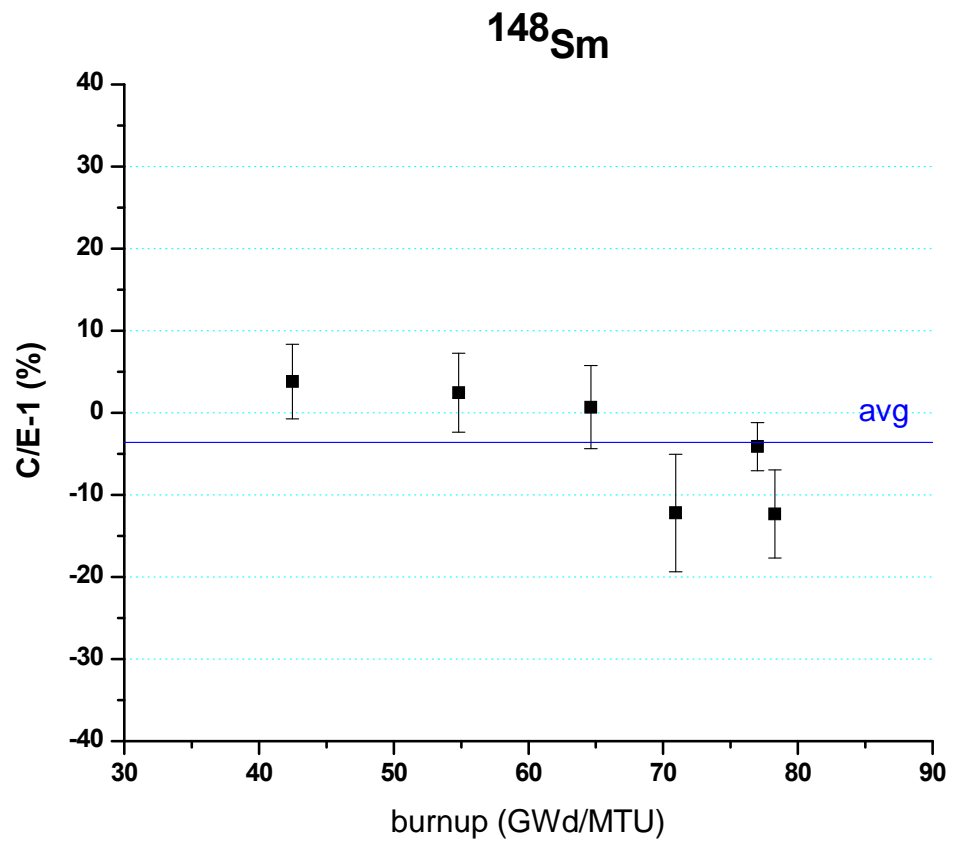

Figure 6.24. Calculation-to-measurement comparison for ${ }^{148} \mathrm{Sm}$. 


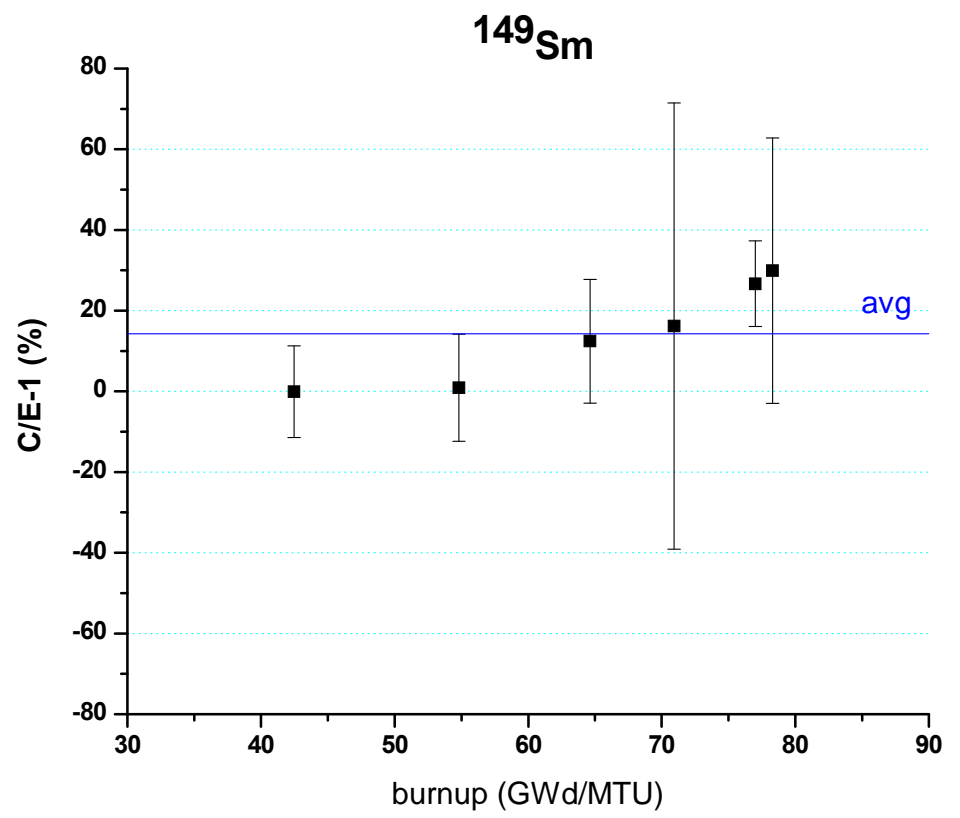

Figure 6.25. Calculation-to-measurement comparison for ${ }^{149} \mathrm{Sm}$.

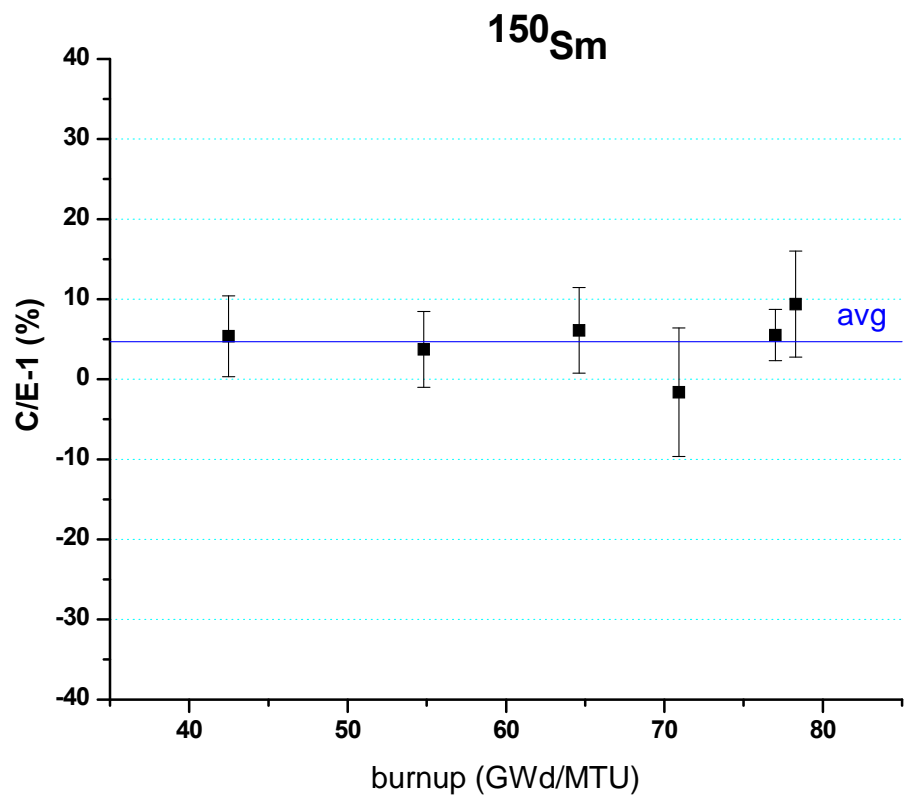

Figure 6.26. Calculation-to-measurement comparison for ${ }^{150} \mathrm{Sm}$. 


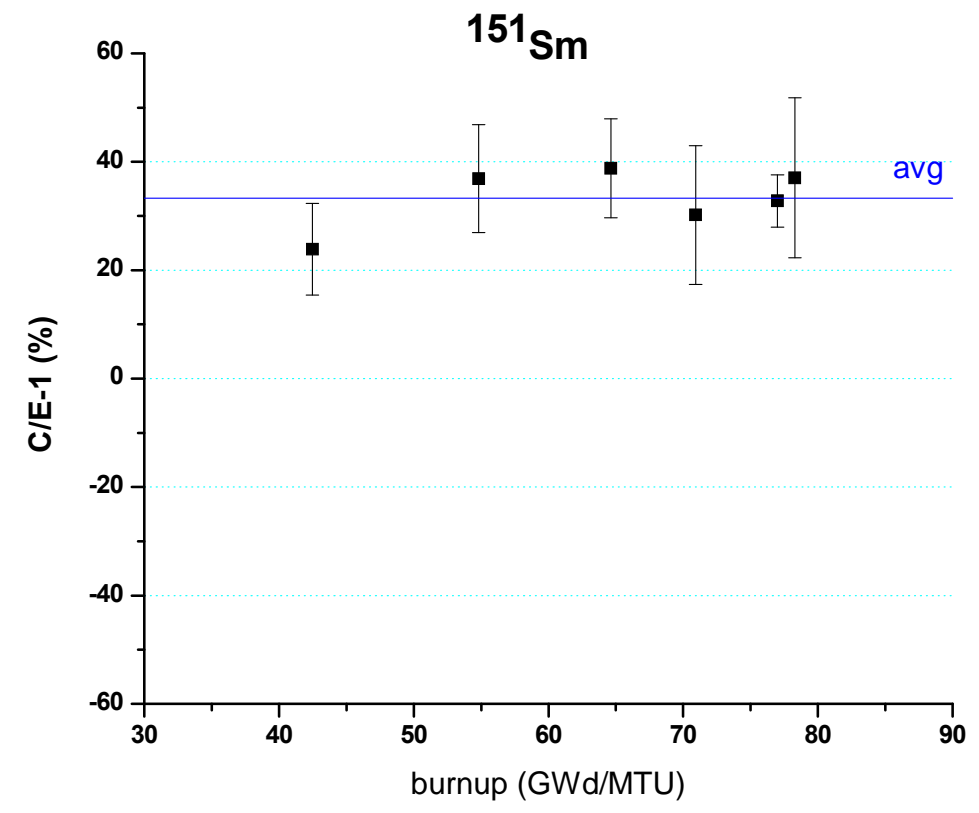

Figure 6.27. Calculation-to-measurement comparison for ${ }^{151} \mathrm{Sm}$.

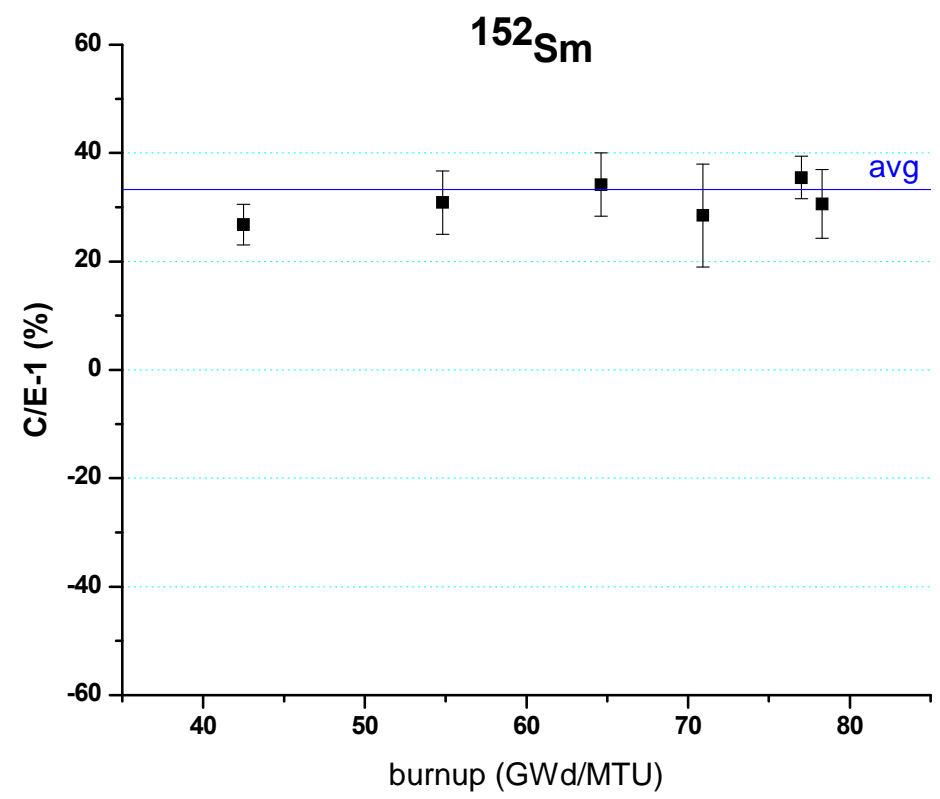

Figure 6.28. Calculation-to-measurement comparison for ${ }^{152} \mathrm{Sm}$. 


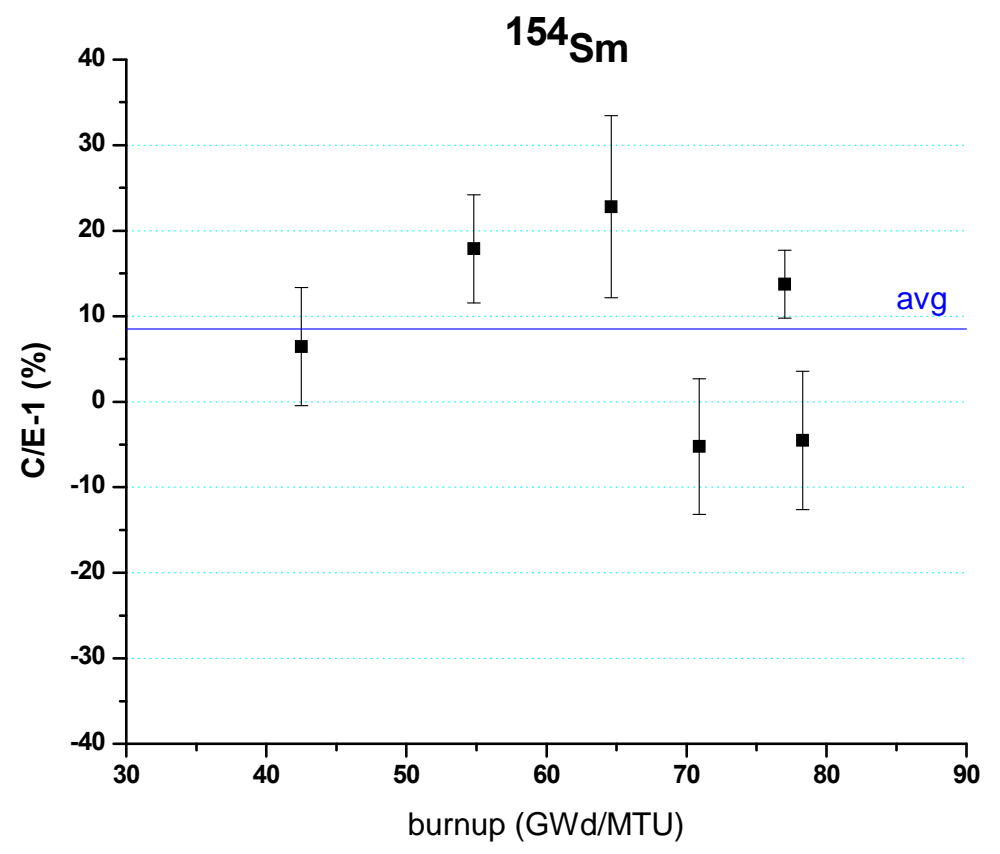

Figure 6.29. Calculation-to-measurement comparison for ${ }^{154} \mathrm{Sm}$.

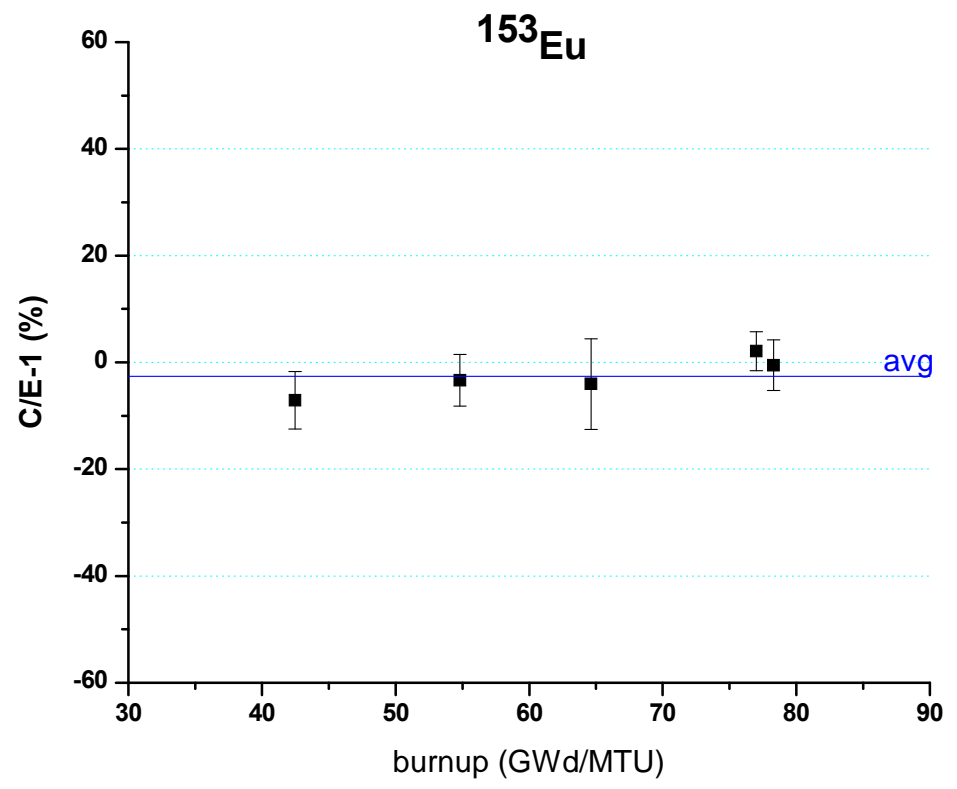

Figure 6.30. Calculation-to-measurement comparison for ${ }^{153} \mathrm{Eu}$. 


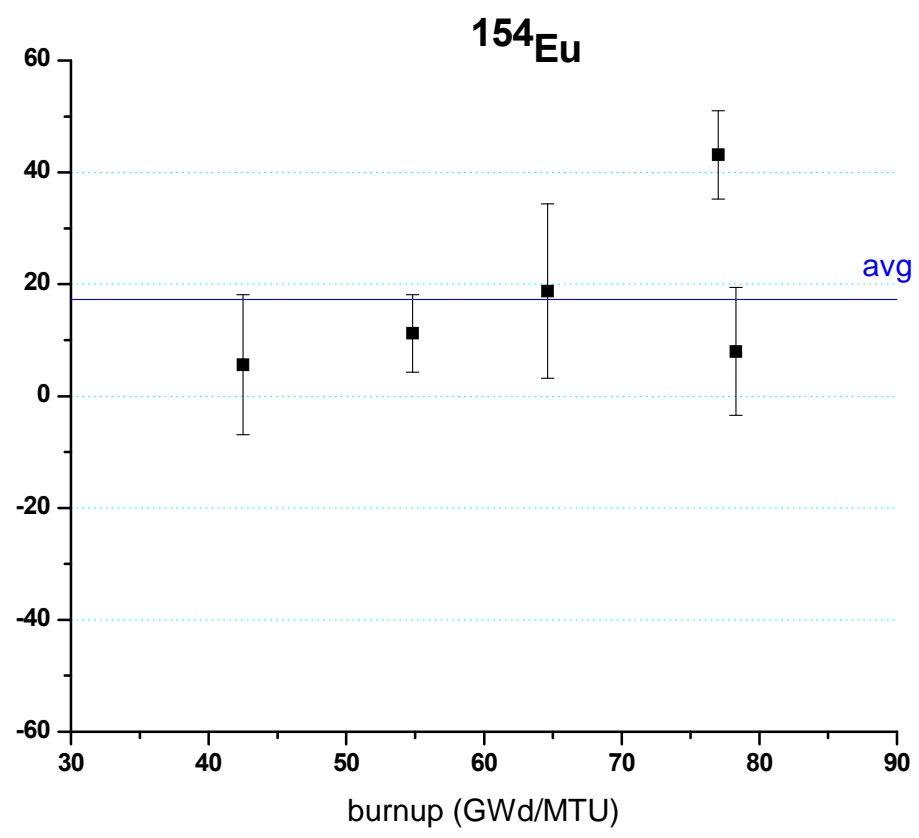

Figure 6.31. Calculation-to-measurement comparison for ${ }^{154} \mathrm{Eu}$.

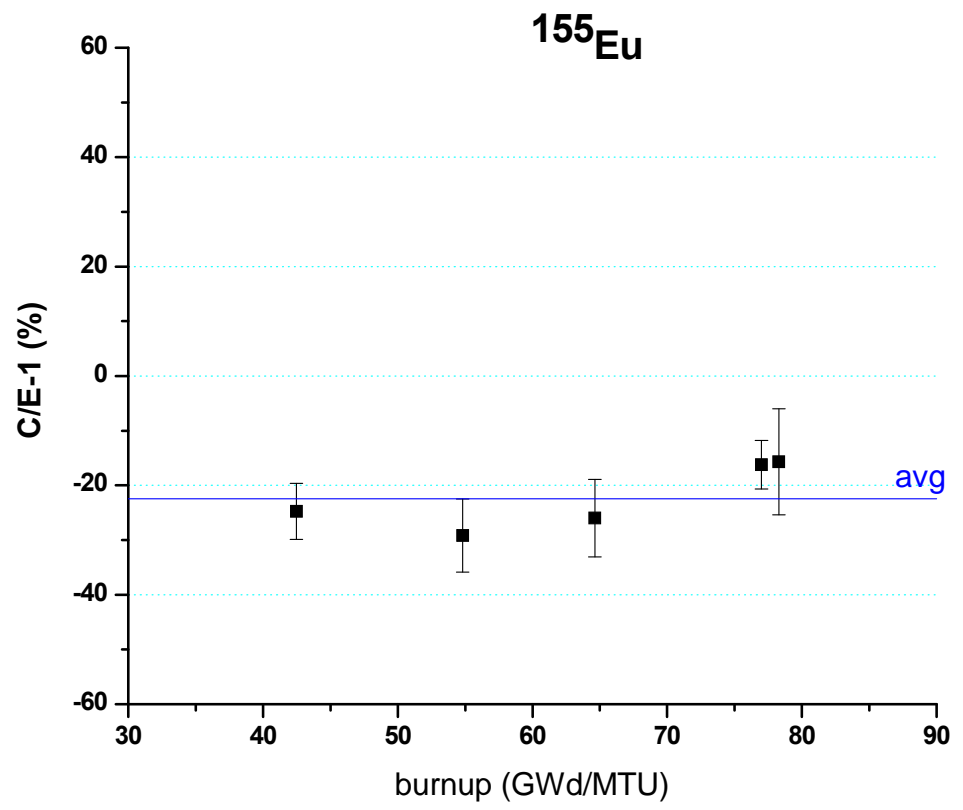

Figure 6.32. Calculation-to-measurement comparison for ${ }^{155} \mathrm{Eu}$. 


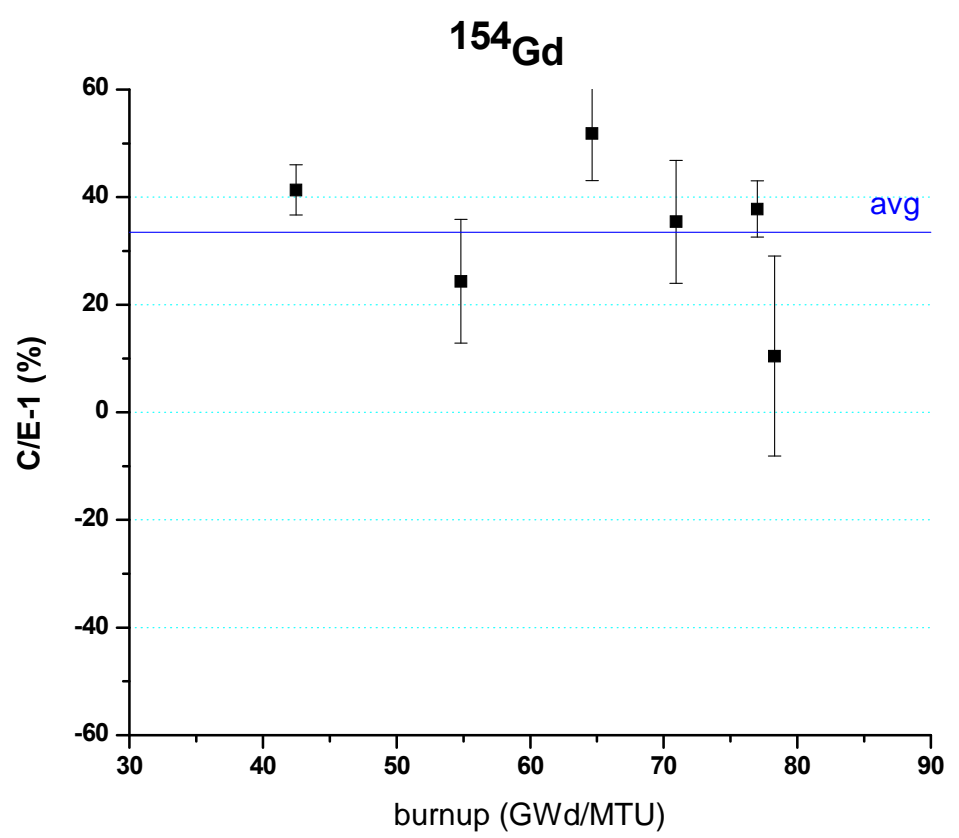

Figure 6.33. Calculation-to-measurement comparison for ${ }^{154} \mathbf{G d}$.

${ }^{155_{\mathrm{Gd}}}$

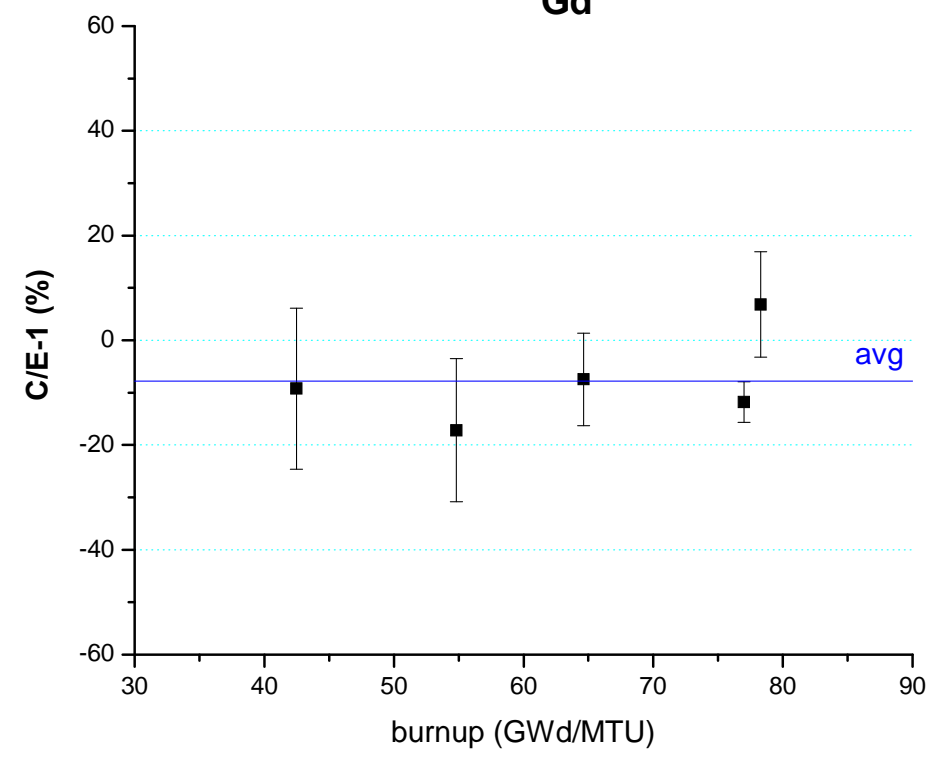

Figure 6.34. Calculation-to-measurement comparison for ${ }^{155} \mathrm{Gd}$. 


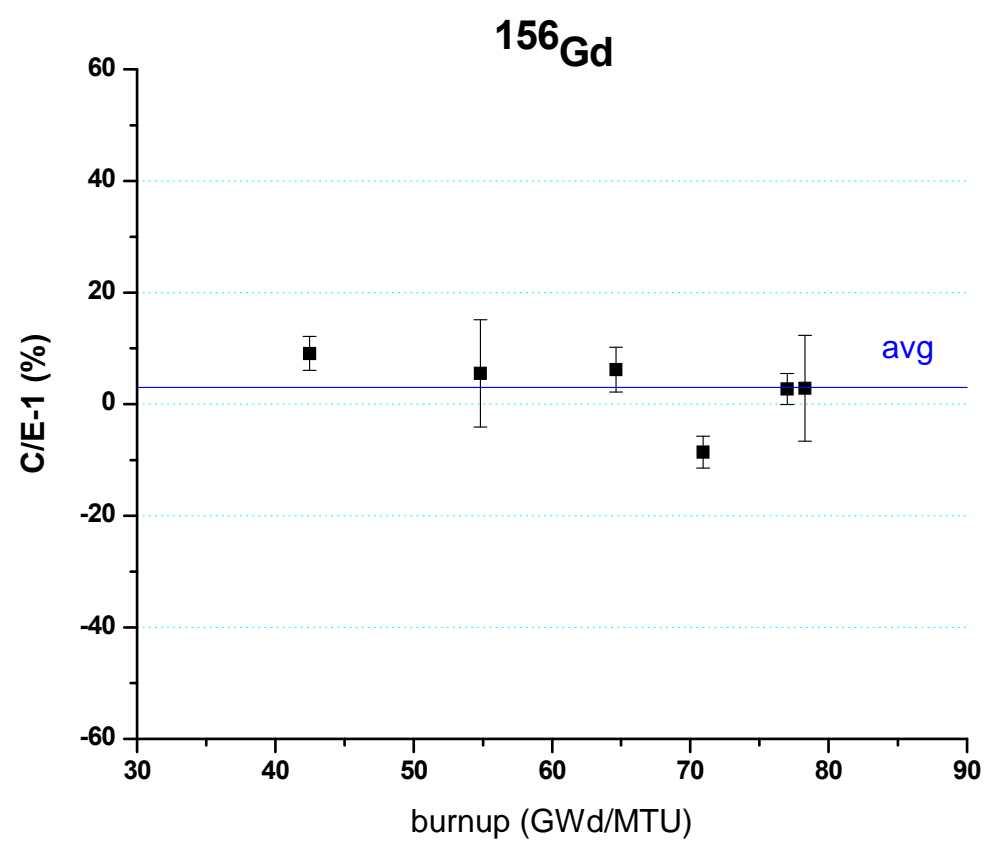

Figure 6.35. Calculation-to-measurement comparison for ${ }^{156} \mathbf{G d}$.

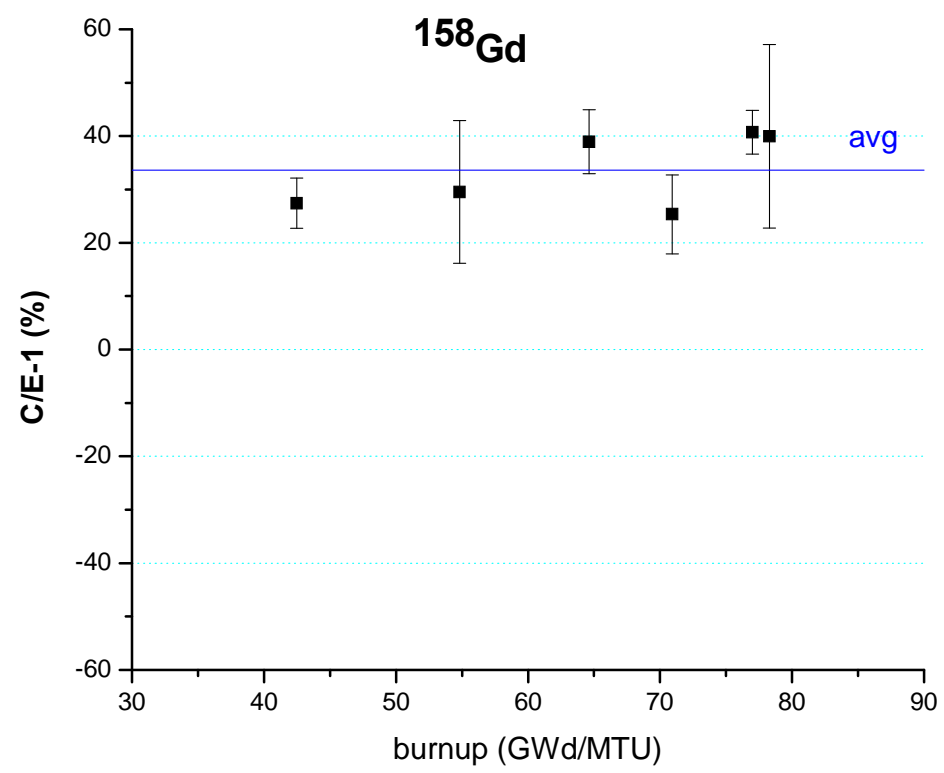

Figure 6.36. Calculation-to-measurement comparison for ${ }^{158} \mathrm{Gd}$. 


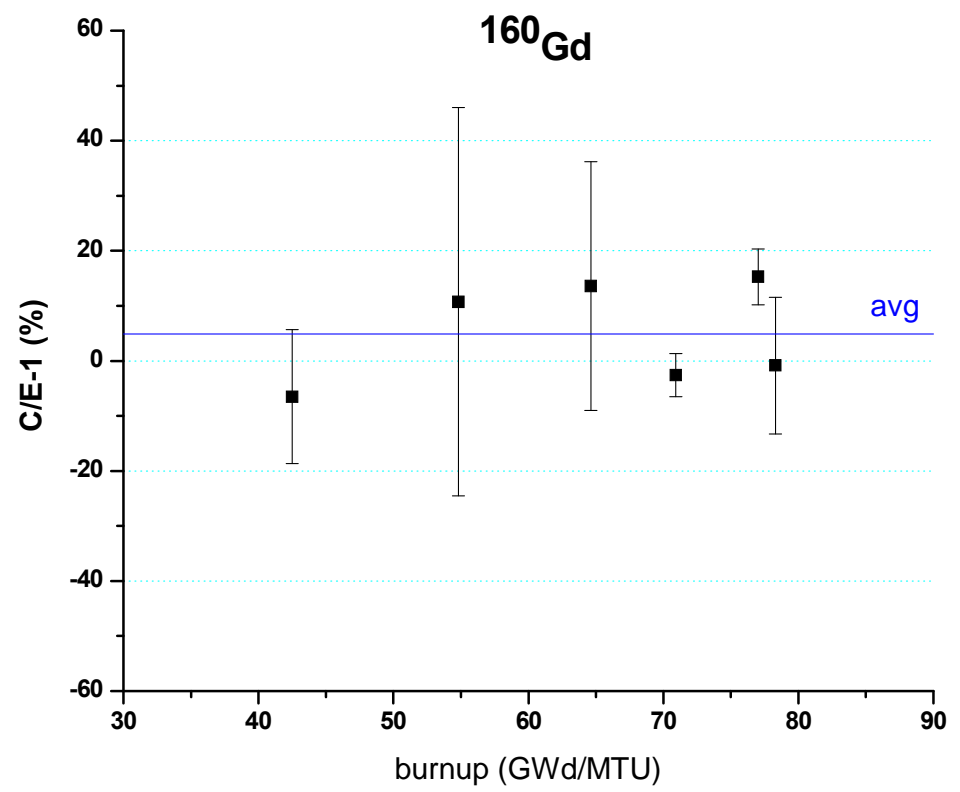

Figure 6.37. Calculation-to-measurement comparison for ${ }^{160} \mathrm{Gd}$.

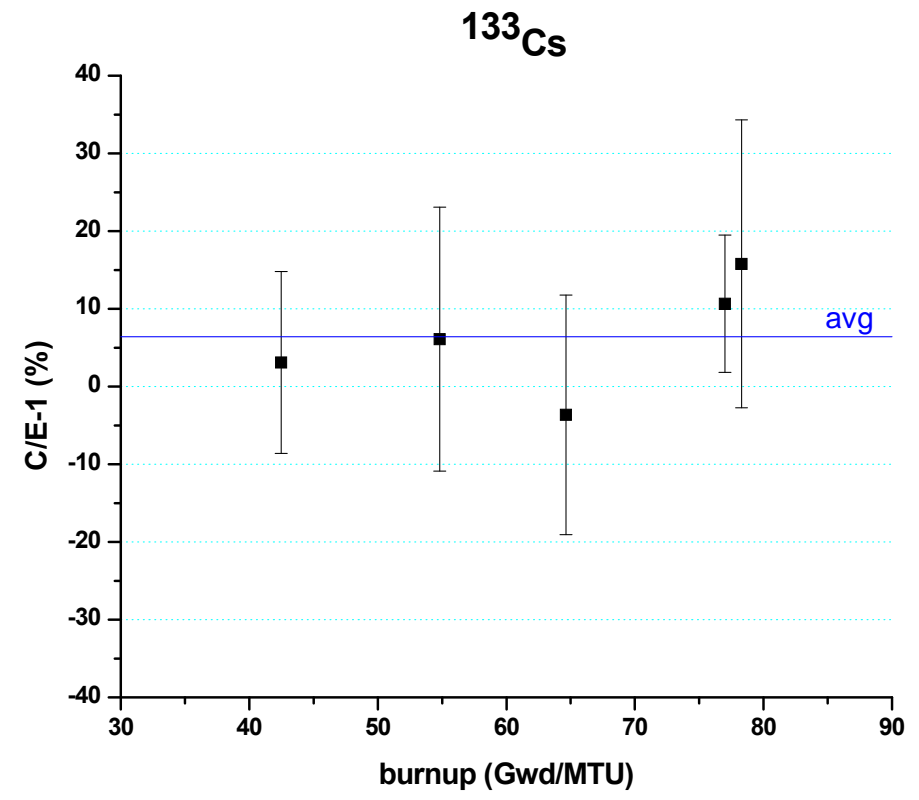

Figure 6.38. Calculation-to-measurement comparison for ${ }^{133} \mathrm{Cs}$. 
${ }^{134} \mathrm{Cs}$

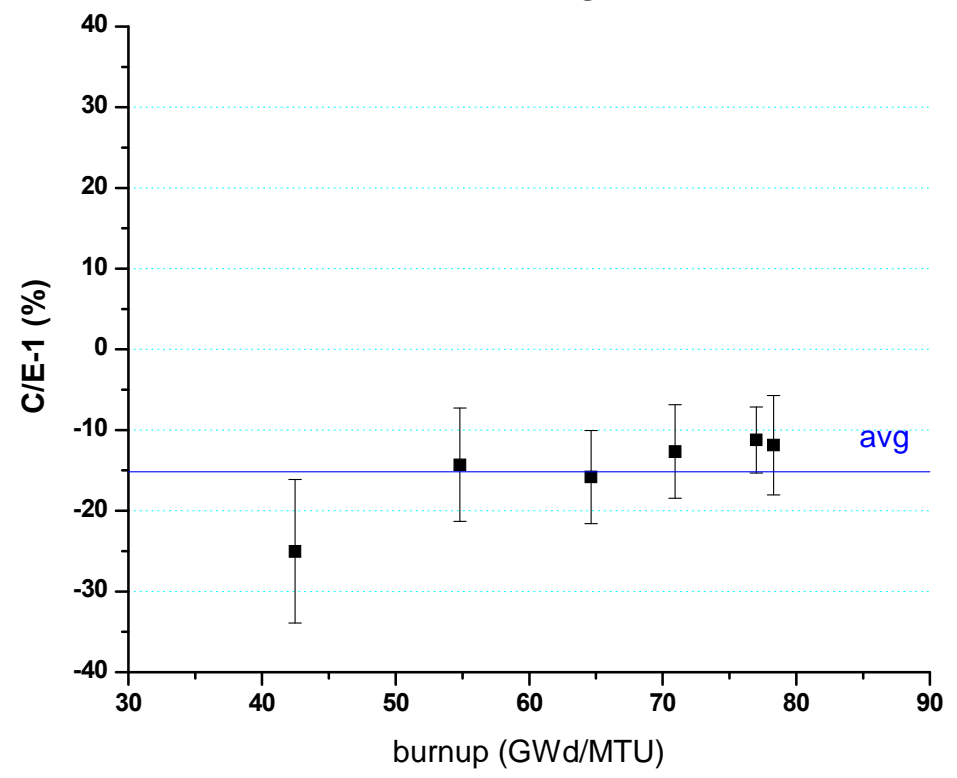

Figure 6.39. Calculation-to-measurement comparison for ${ }^{134} \mathrm{Cs}$.

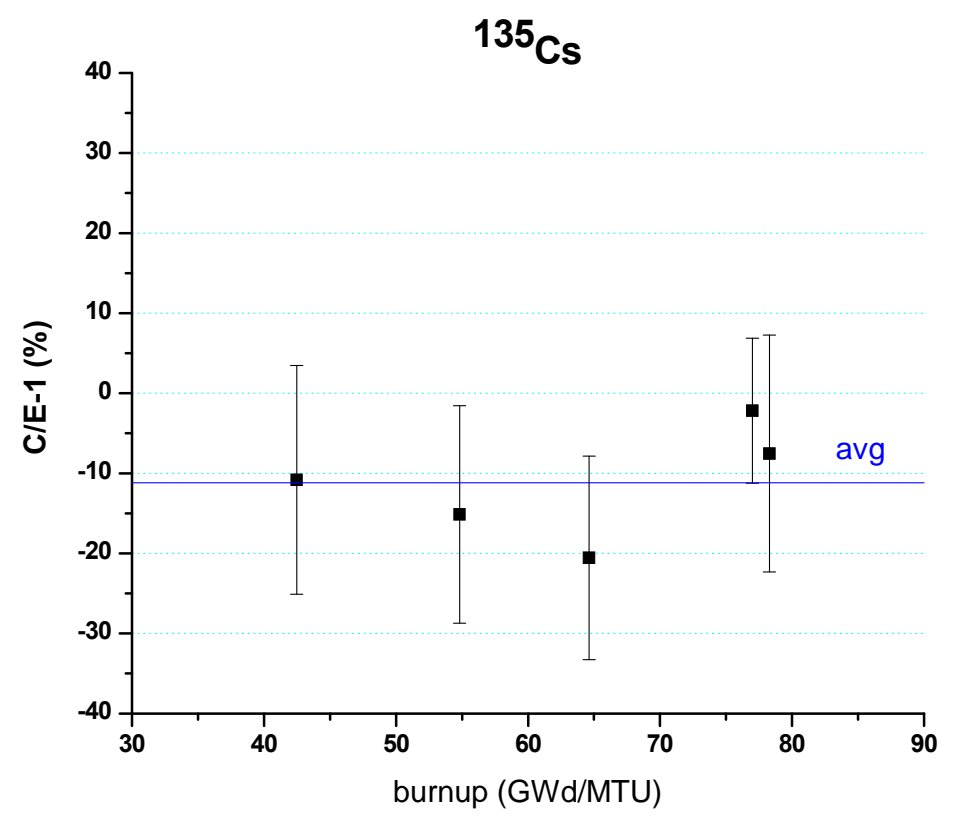

Figure 6.40. Calculation-to-measurement comparison for ${ }^{135} \mathrm{Cs}$. 


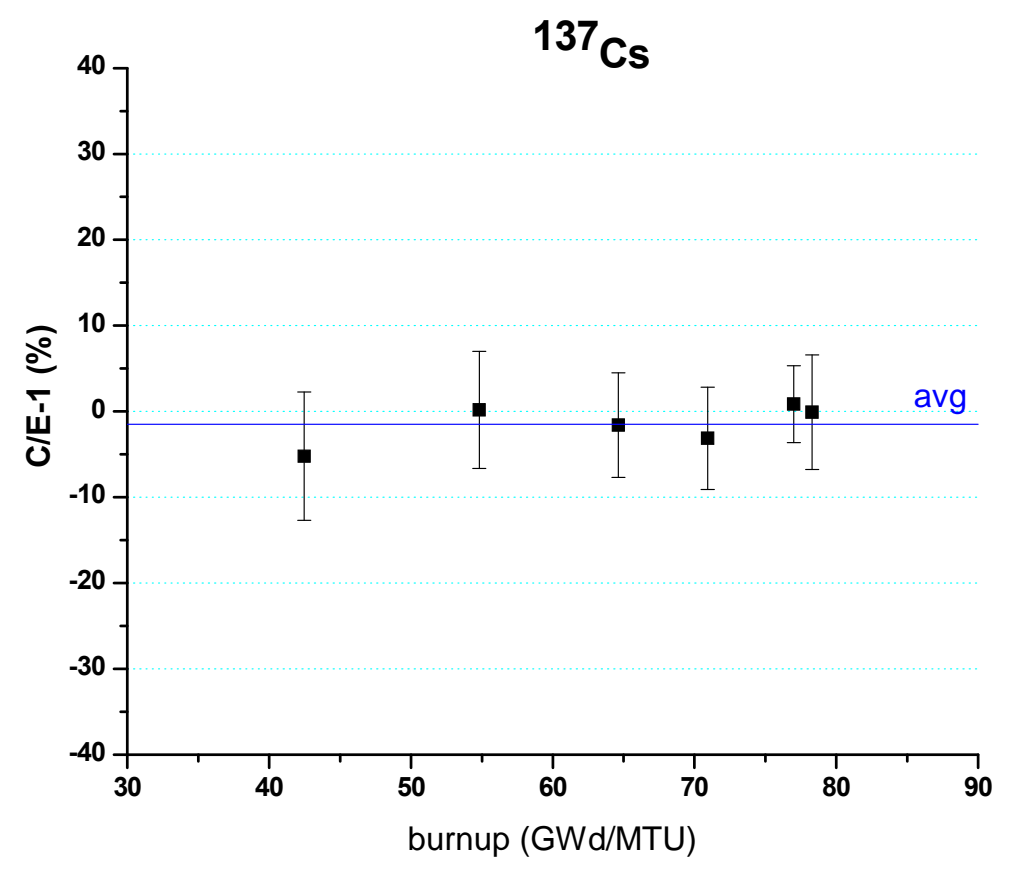

Figure 6.41. Calculation-to-measurement comparison for ${ }^{137} \mathrm{Cs}$.

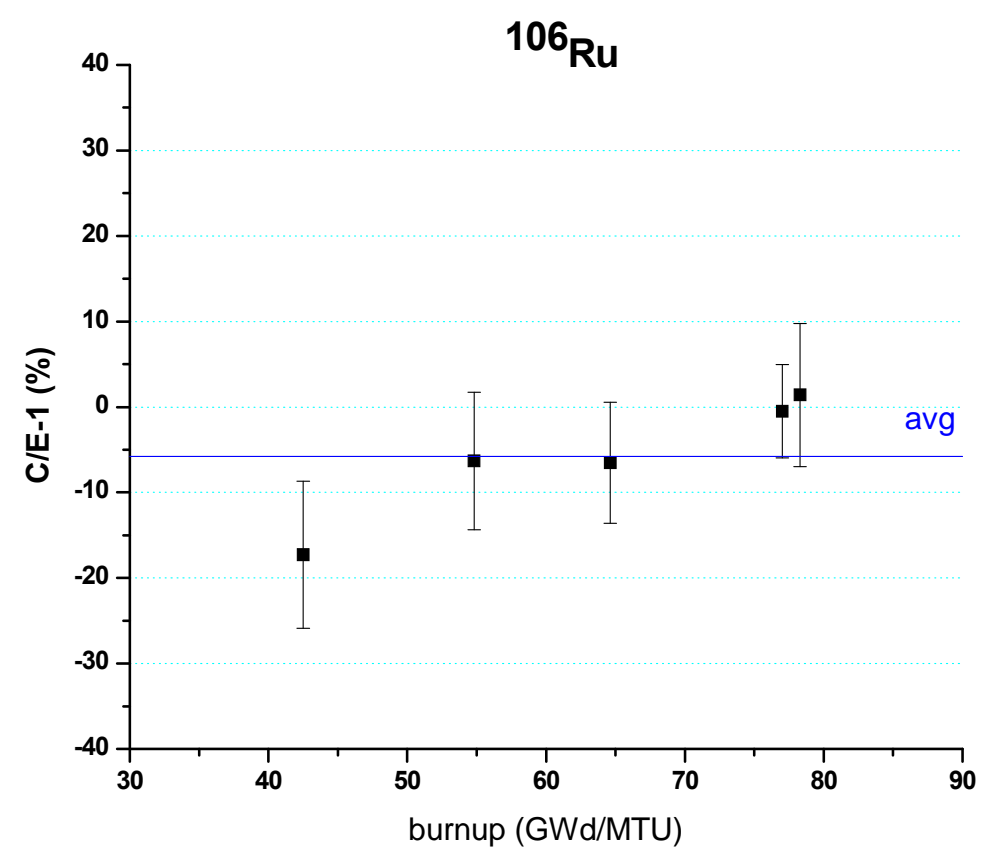

Figure 6.42. Calculation-to-measurement comparison for ${ }^{106} \mathrm{Ru}$. 


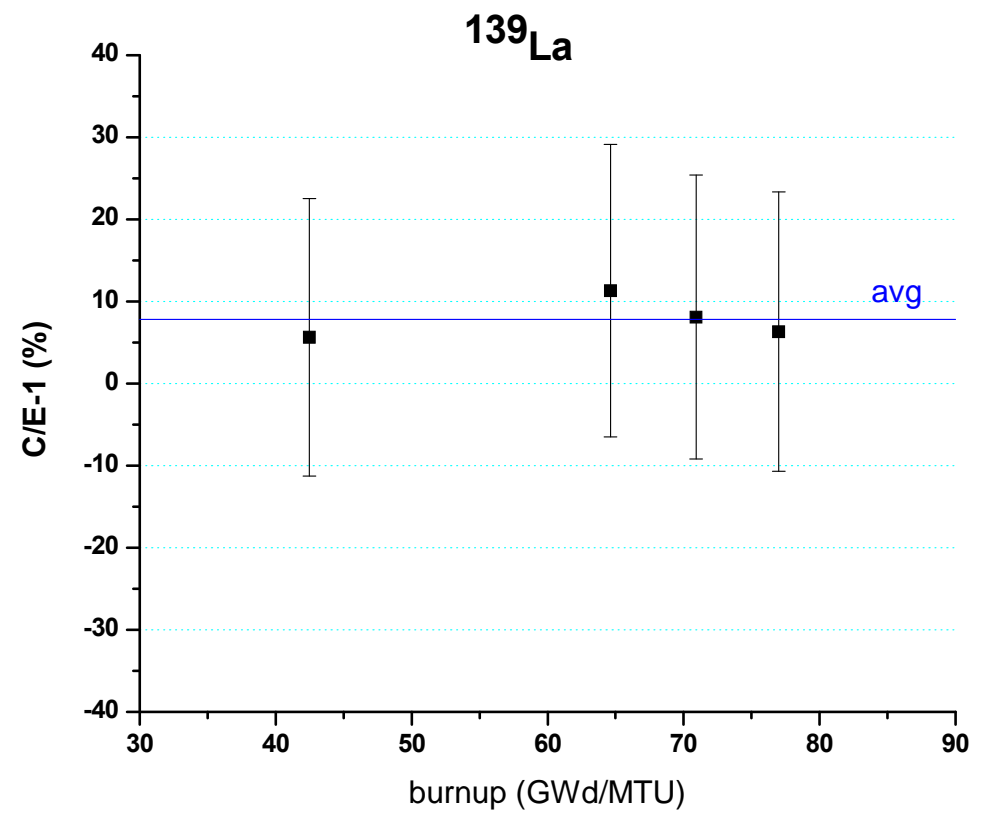

Figure 6.43. Calculation-to-measurement comparison for ${ }^{139} \mathrm{La}$.

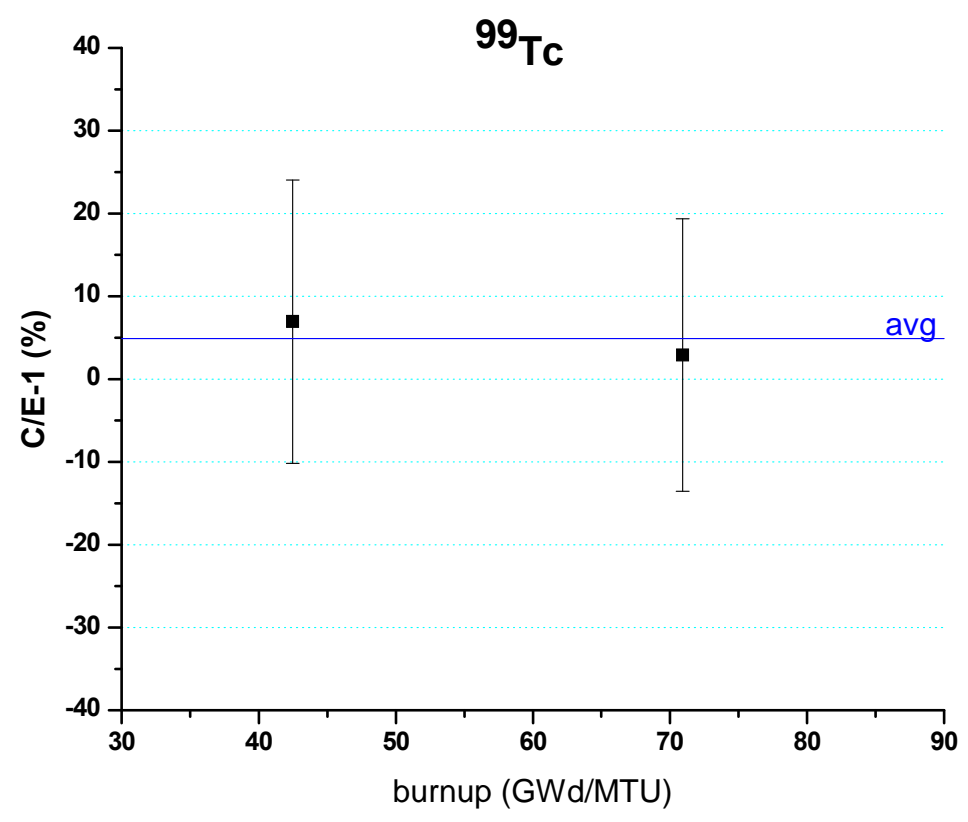

Figure 6.44. Calculation-to-measurement comparison for ${ }^{99} \mathrm{Tc}$. 


\section{SUMMARY}

This report documents radiochemical assay data for high-burnup spent nuclear fuel that were measured through a high-burnup fuel program coordinated by Spanish organizations. The measurements analyzed in this report include six unique fuel samples with an initial enrichment of $4.5 \mathrm{wt} \%{ }^{235} \mathrm{U}$ that were obtained from three fuel rods irradiated in the Vandellós II PWR operated in Spain. Multiple measurements, available for three of these six samples, were combined using the measurement uncertainty to weight the different measurements, leading to combined datasets with reduced measurement uncertainties. The samples cover a burnup range from 42 to $78 \mathrm{GWd} / \mathrm{MTU}$.

The experimental data were used to validate the 2-D lattice depletion sequence TRITON in the SCALE code system. Individual TRITON models were developed for each of the samples considered. Information on the radiochemical analysis methods and uncertainties, assembly design description and irradiation history, and computational models and results obtained using the SCALE code system are included. The data are presented in sufficient detail to allow an independent analysis to be performed.

The samples measured in this program were obtained from fuel rods that were moved from one assembly to another to obtain very high burnups. The modeling and simulation of these samples for the depletion analysis were very complex compared to typical commercial fuels. Given the fuel reconfiguration during irradiation, the ability to use the data will depend to a large extent on the capabilities of the code used to simulate the reconfigurations. However, for a code with these simulation capabilities, the measurement data are a valuable dataset for validation, as the measurements include extensive isotopic data for the actinides and fission products of high importance to spent fuel safety applications, including burnup credit, decay heat, and radiation source terms. 


\section{REFERENCES}

1. J. M. Conde, C. Alejano, and J. M. Rey, Nuclear Fuel Research Activities of the Consejo de Seguridad Nuclear, Trans. International Meeting on LWR Fuel Performance, Top Fuel 2006, Salamanca, Spain (2006).

2. J. M. Conde, J. M. Alonso, J. A. Gago, P. González, M. Novo, and L. E. Herranz, Spanish R\&D Program on Spent Fuel Dry Storage, Trans. International Meeting on LWR Fuel Performance, Top Fuel 2006, Salamanca, Spain (2006).

3. H. U. Zwicky and J. Low, Fuel Pellet Isotopic Analyses of Vandellós 2 Rods WZtR165 and WZR0058, Final Report, STUDSVIK/N(H)-03/069, Rev. 1 (2008).

4. H. U. Zwicky and J. Low, Fuel Pellet Isotopic Analyses of Vandellós 2 Rods WZtR165 and WZR0058: Qualification of Method, STUDSVIK/N(H)-04/002, Rev. 2 (2008).

5. H. U. Zwicky and J. Low, Fuel Pellet Isotopic Analyses of Vandellós 2 Rods WZtR165 and WZR0058: Complementary Report, STUDSVIK/N(H)-04/135, Rev. 1 (2008).

6. H. U. Zwicky, J. Low, and M. Granfors, Additional Fuel Pellet Isotopic Analyses of Vandellós 2 Rods WZtR160 and WZR0058, Final Report, STUDSVIK/N-07/140 (2008).

7. P. R. Bevington, Data Reduction and Error Analysis for the Physical Sciences, McGraw-Hill Book Company, New York (1969).

8. ARIANE International Programme-Final Report, ORNL/SUB/97-XSV750-1, Oak Ridge National Laboratory, Oak Ridge, Tennessee (May 1, 2003).

9. A. Romano, "Irradiation data of the three fuel rods for high burnup fuel isotope determination," COM-006998 Rev. 2, ENUSA, Spain (2010).

10. SCALE: A Modular Code System for Performing Standardized Computer Analyses for Licensing Evaluation, ORNL/TM-2005/39, Version 5.1, Vols. I-III, Oak Ridge National Laboratory, Oak Ridge, Tennessee, November 2006. Available from Radiation Safety Information Computational Center at Oak Ridge National Laboratory as CCC-732.

11. G. Ilas, I. C. Gauld, F. C. Difilippo, and M. B. Emmett, Analysis of Experimental Data for High Burnup PWR Spent Fuel Isotopic Validation-Calvert Cliffs, Takahama, and Three Mile island Reactors, NUREG/CR-6968 (ORNL/TM-2008/071), prepared for the U.S. Nuclear Regulatory Commission by Oak Ridge National Laboratory, Oak Ridge, Tennessee (May 2008).

12. G. Ilas and I.C. Gauld, "SCALE 6 Analysis of Isotopic Assay Benchmarks for PWR Spent Fuel," Trans. Am. Nucl. Soc. 101, 691 (2009). 
APPENDIX A

TRITON INPUT FILES 



\section{A.1 TRITON INPUT FILE FOR SAMPLE E58-88, CYCLE 7}

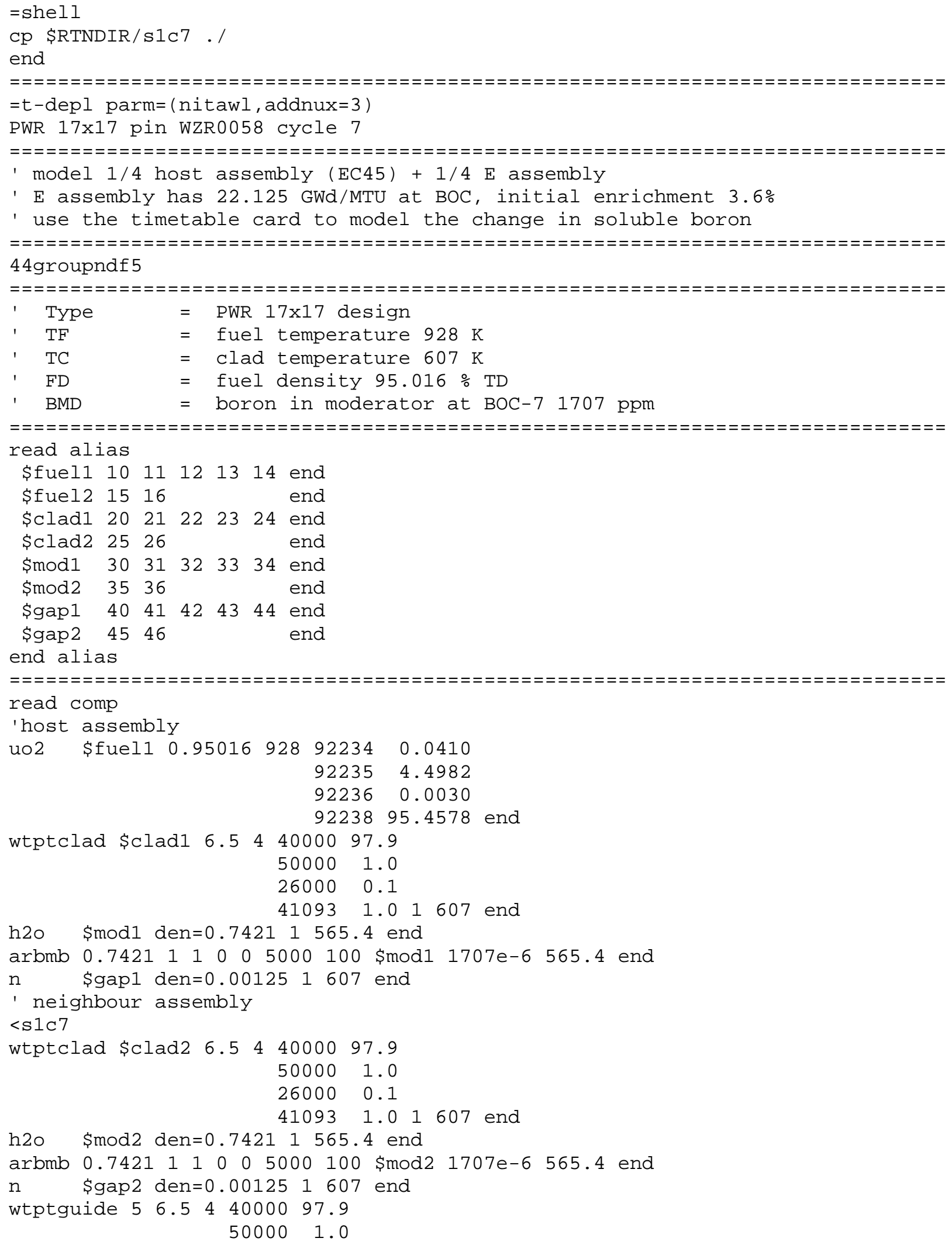


$26000 \quad 0.1$

410931.01565 .4 end

end comp

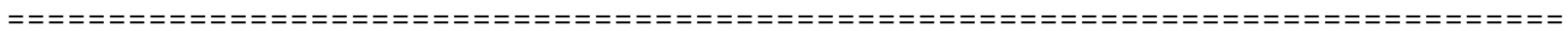

read celldata

latticecell squarepitch pitch=1.2600 \$mod1

fueld=0.8191 \$fuel1

gapd=0.8356 \$gap1

cladd $=0.9500 \$ c l a d 1$ end

latticecell squarepitch pitch=1.2600 \$mod2

fueld=0.8191 \$fuel2

gapd $=0.8356 \quad \$ g a p 2$

end celldata

cladd $=0.9500$ \$clad2 end

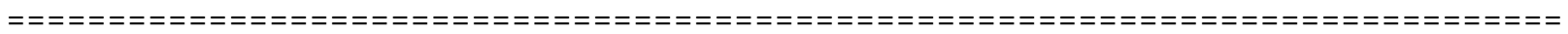
read depletion

$\begin{array}{lllllll}-10 & 11 & 12 & 13 & 14 & 15 & 16\end{array}$

end depletion

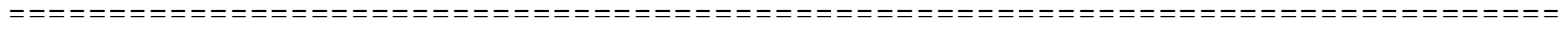

read burndata

power=31.015 burn=358 down=33 nlib=7 end

end burndata

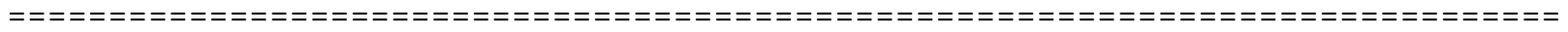

read timetable

density \$mod1 250105011

01.000

10.988

20.931

30.860

$4 \quad 0.825$

50.802

$6 \quad 0.776$

$7 \quad 0.809$

$8 \quad 0.851$

$9 \quad 0.781$

$\begin{array}{ll}10 & 0.777\end{array}$

3580.000 end

density \$mod2 250105011

01.000

10.988

20.931

30.860

$4 \quad 0.825$

$5 \quad 0.802$

$6 \quad 0.776$

$7 \quad 0.809$

$8 \quad 0.851$

$9 \quad 0.781$

$\begin{array}{ll}10 & 0.777\end{array}$

3580.000 end

end timetable

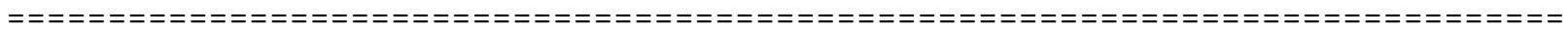

read model

PWR 17x17

read parm

cmfd=yes xycmfd=4 run=yes echo=yes drawit=yes

end parm 


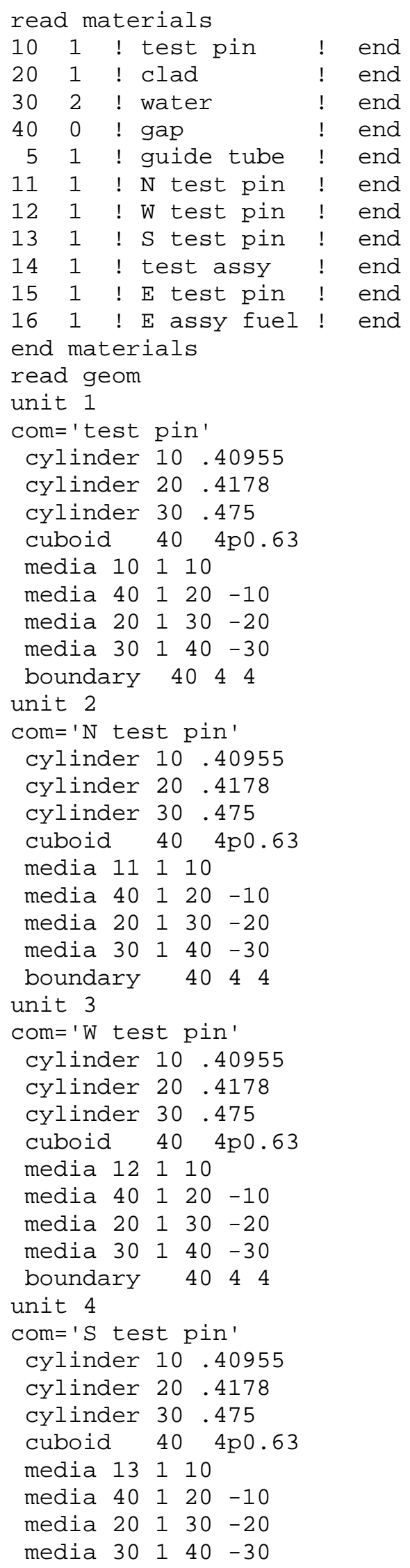




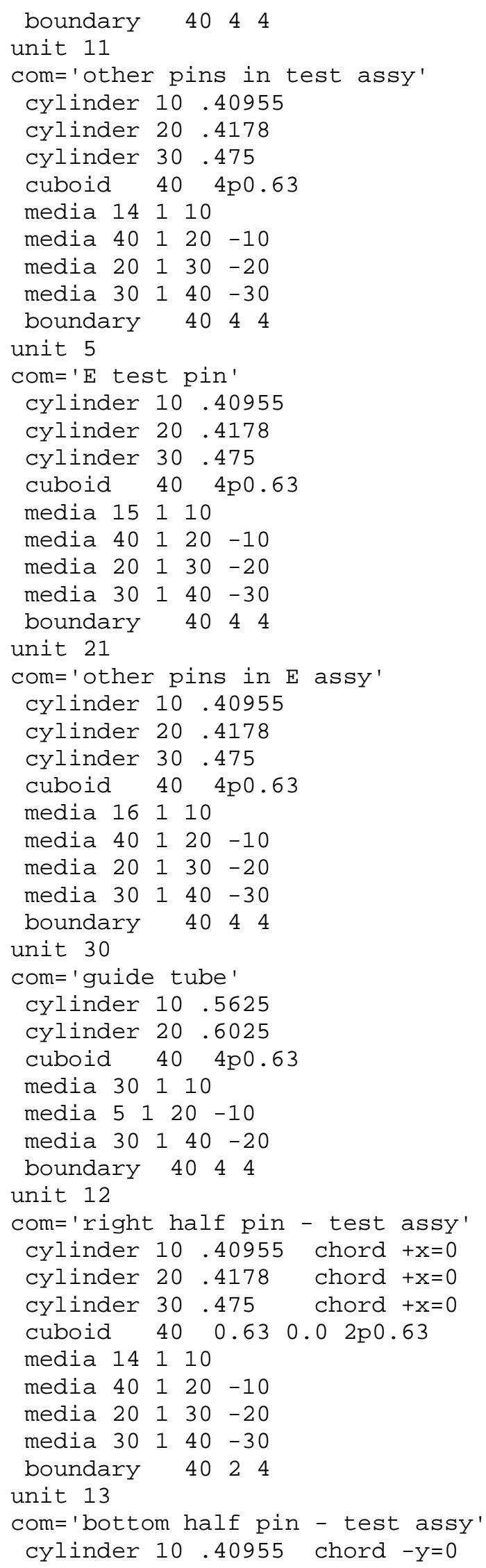




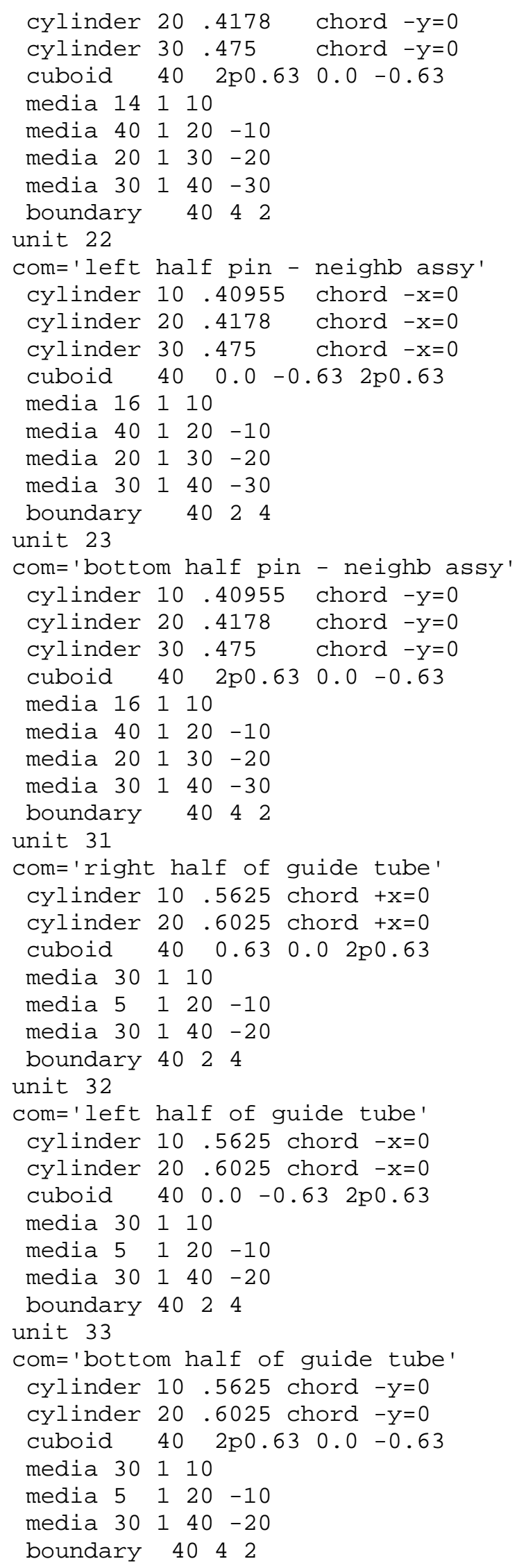




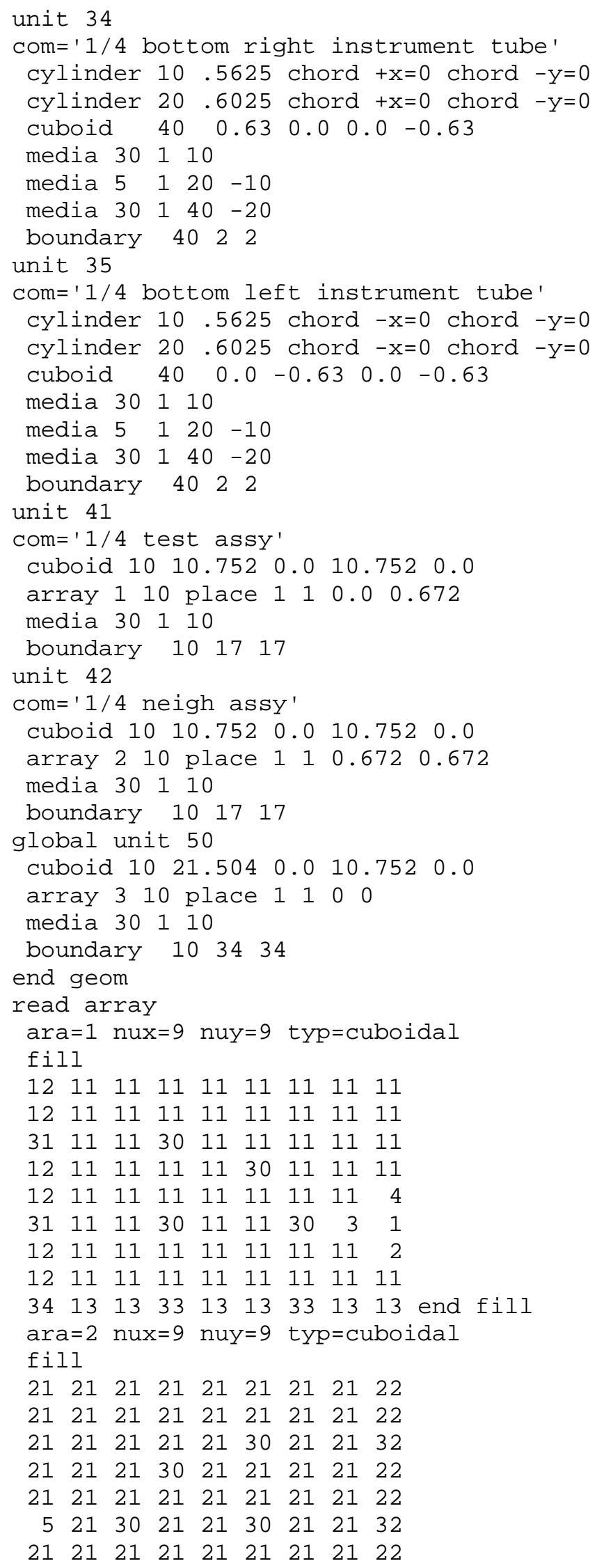




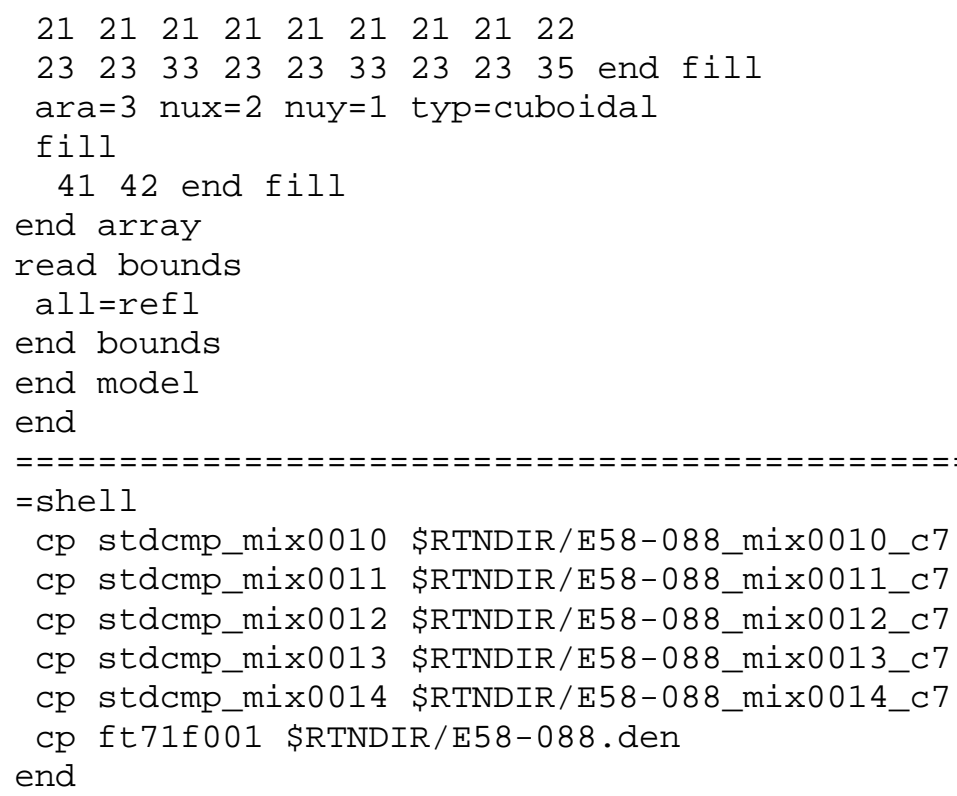




\section{A.2 TRITON INPUT FILE FOR SAMPLE E58-88, CYCLE 8}

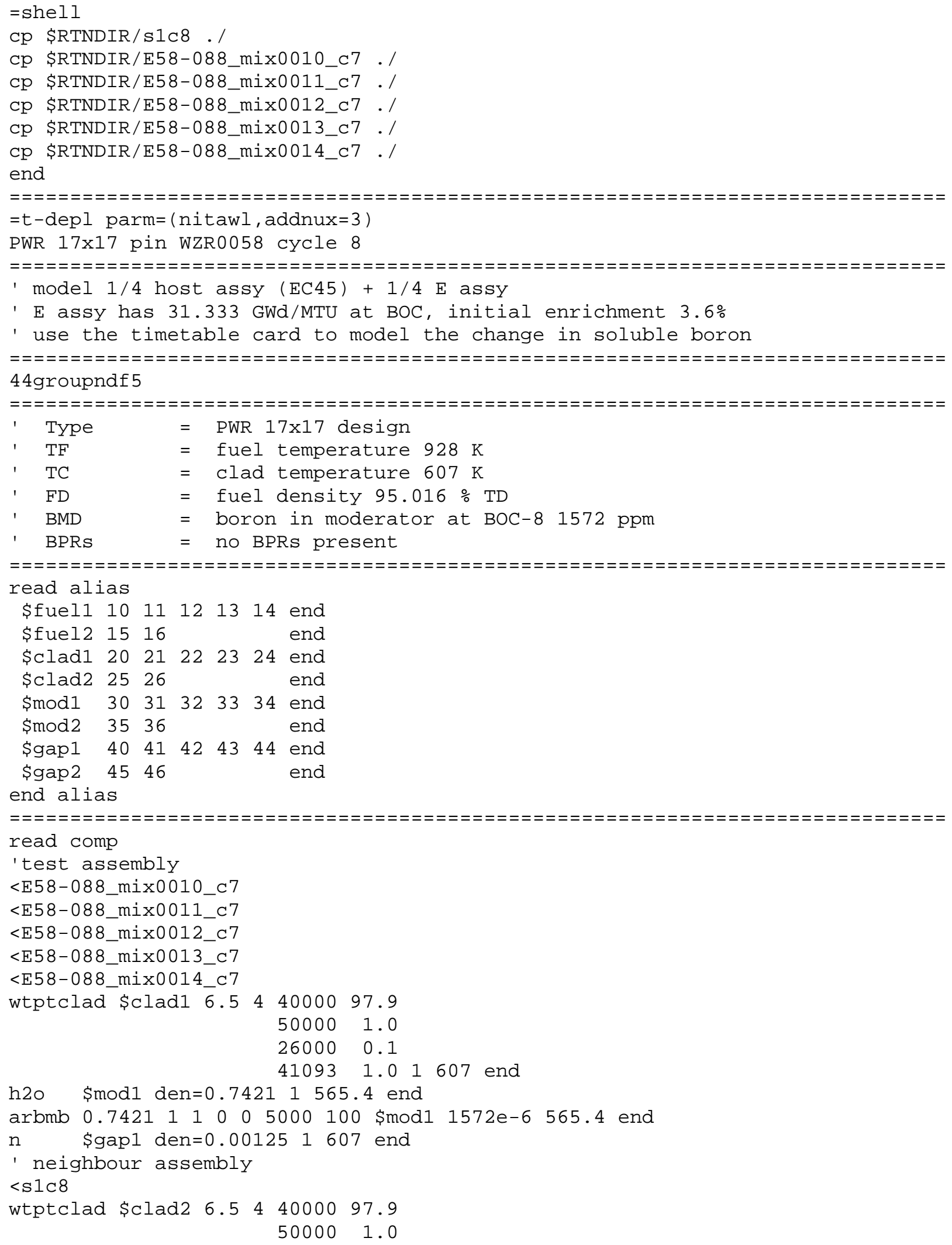




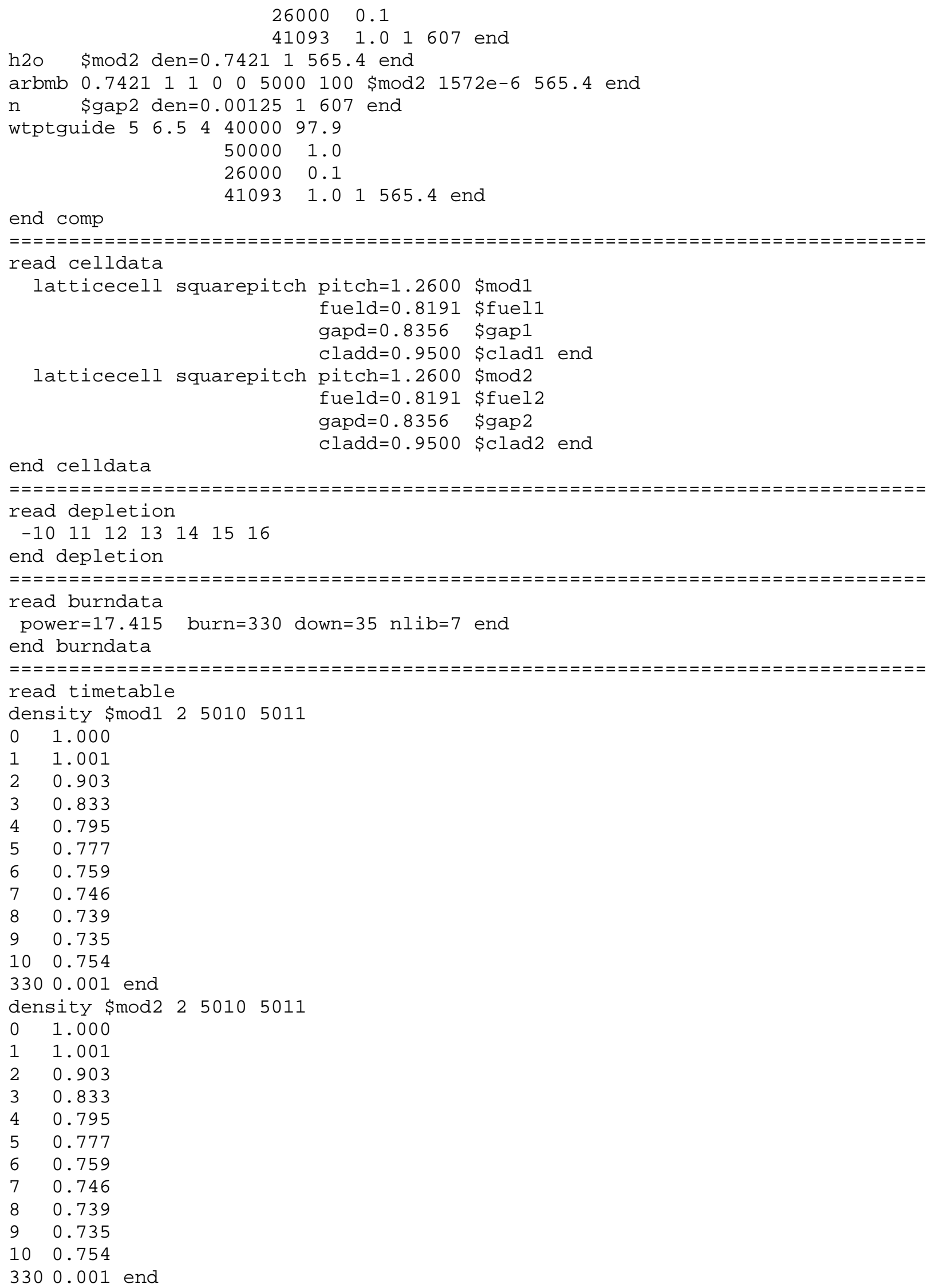


end timetable

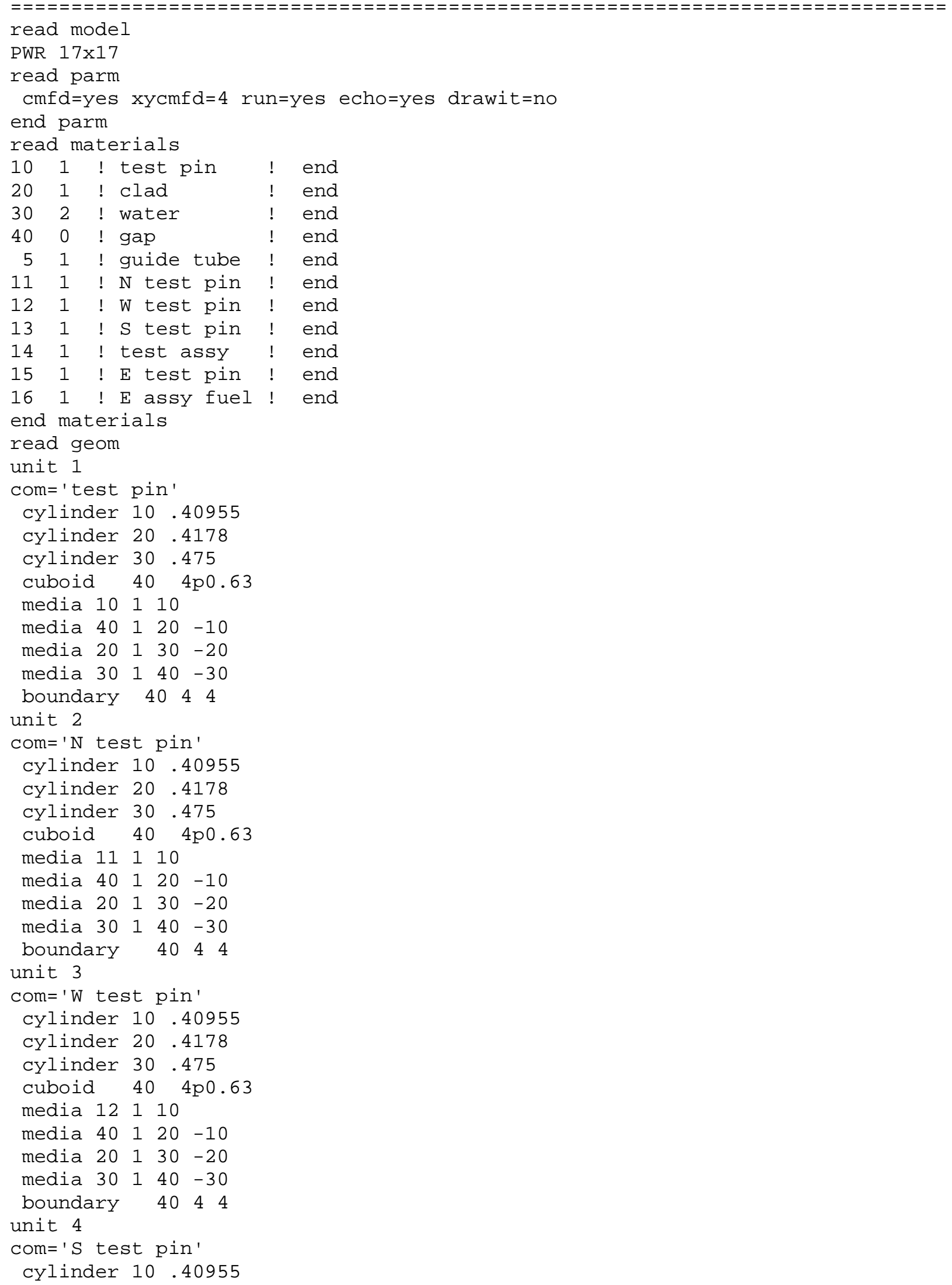




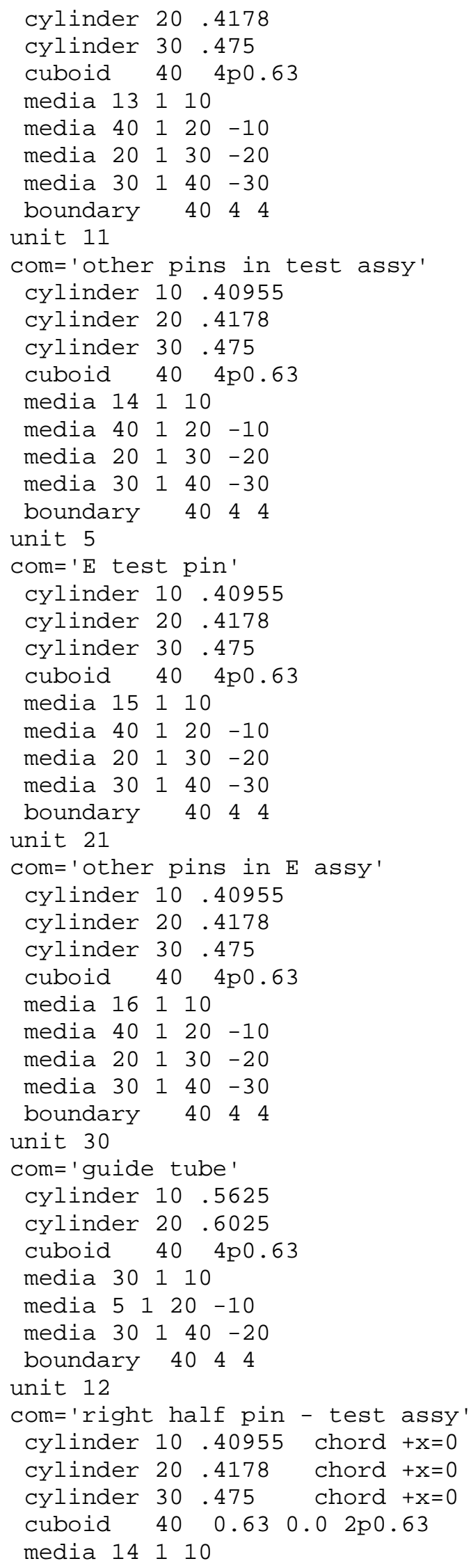




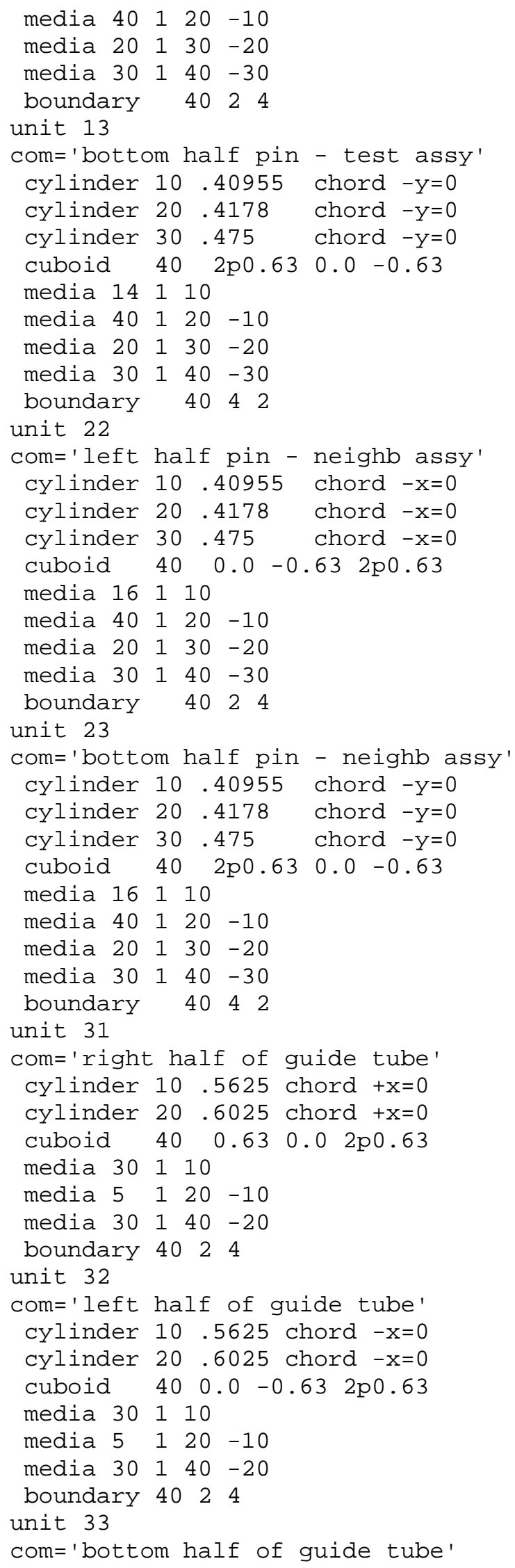




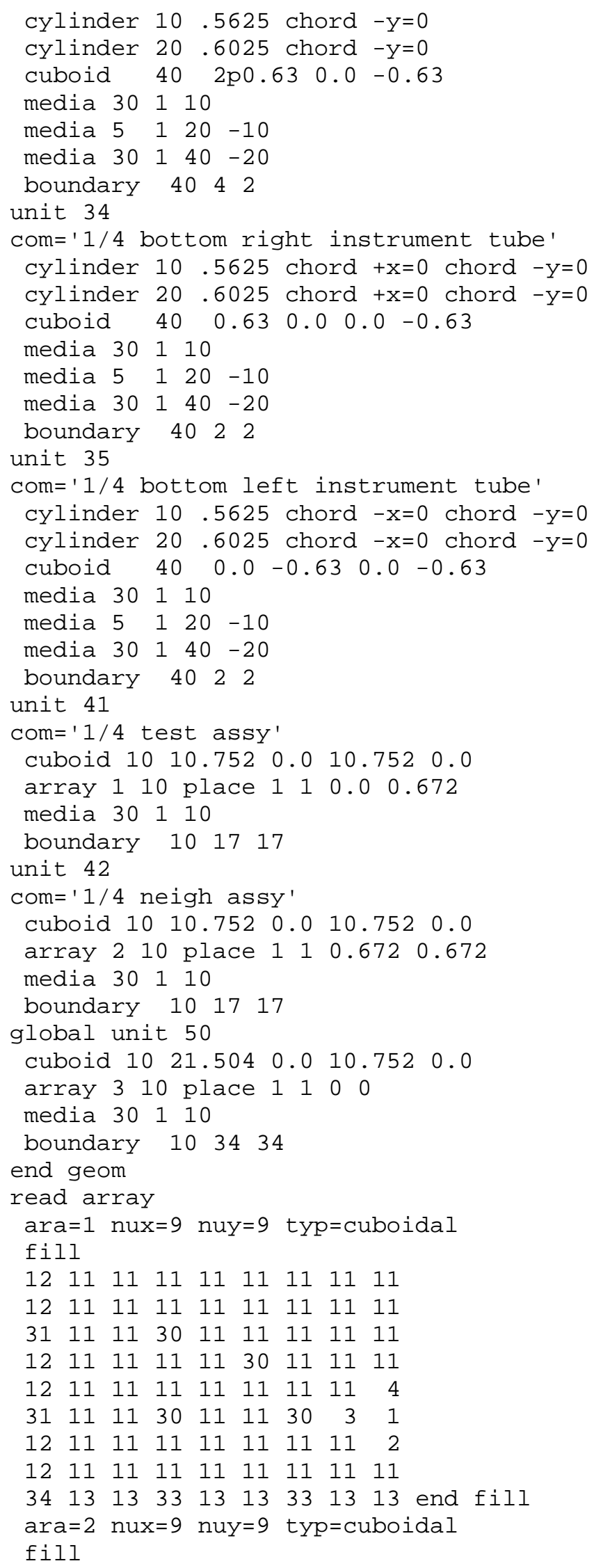


$\begin{array}{lllllllll}21 & 21 & 21 & 21 & 21 & 21 & 21 & 21 & 22\end{array}$

$\begin{array}{lllllllll}21 & 21 & 21 & 21 & 21 & 21 & 21 & 21 & 22\end{array}$

$\begin{array}{lllllllll}21 & 21 & 21 & 21 & 21 & 30 & 21 & 21 & 32\end{array}$

$\begin{array}{lllllllll}21 & 21 & 21 & 30 & 21 & 21 & 21 & 21 & 22\end{array}$

$\begin{array}{lllllllll}21 & 21 & 21 & 21 & 21 & 21 & 21 & 21 & 22\end{array}$

$\begin{array}{lllllllll}5 & 21 & 30 & 21 & 21 & 30 & 21 & 21 & 32\end{array}$

$\begin{array}{lllllllll}21 & 21 & 21 & 21 & 21 & 21 & 21 & 21 & 22\end{array}$

$\begin{array}{lllllllll}21 & 21 & 21 & 21 & 21 & 21 & 21 & 21 & 22\end{array}$

$\begin{array}{lllllllll}23 & 23 & 33 & 23 & 23 & 33 & 23 & 23 & 35\end{array}$ end fill

ara=3 nux=2 nuy=1 typ=cuboidal

fill

4142 end fill

end array

read bounds

all=refl

end bounds

end model

end

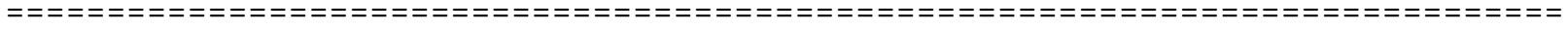

shell

cp stdcmp_mix0010 \$RTNDIR/E58-088_mix0010_c8

cp stdcmp_mix0011 \$RTNDIR/E58-088_mix0011_c8

cp stdcmp_mix0012 \$RTNDIR/E58-088_mix0012_c8

cP stdcmp_mix0013 \$RTNDIR/E58-088_mix0013_c8

cp stdcmp_mix0014 \$RTNDIR/E58-088_mix0014_c8

end 


\section{A.3 TRITON INPUT FILE FOR SAMPLE E58-88, CYCLE 9}

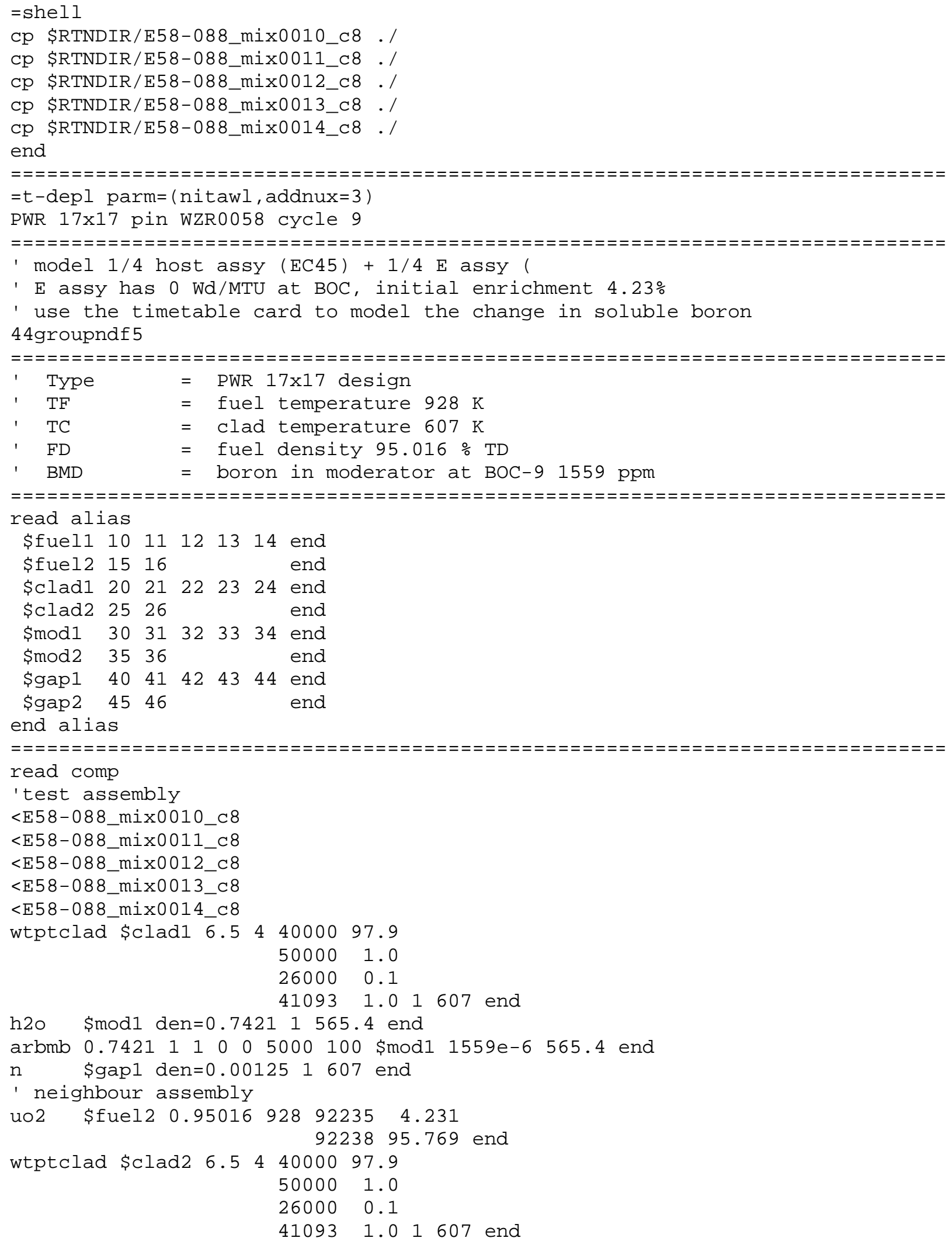




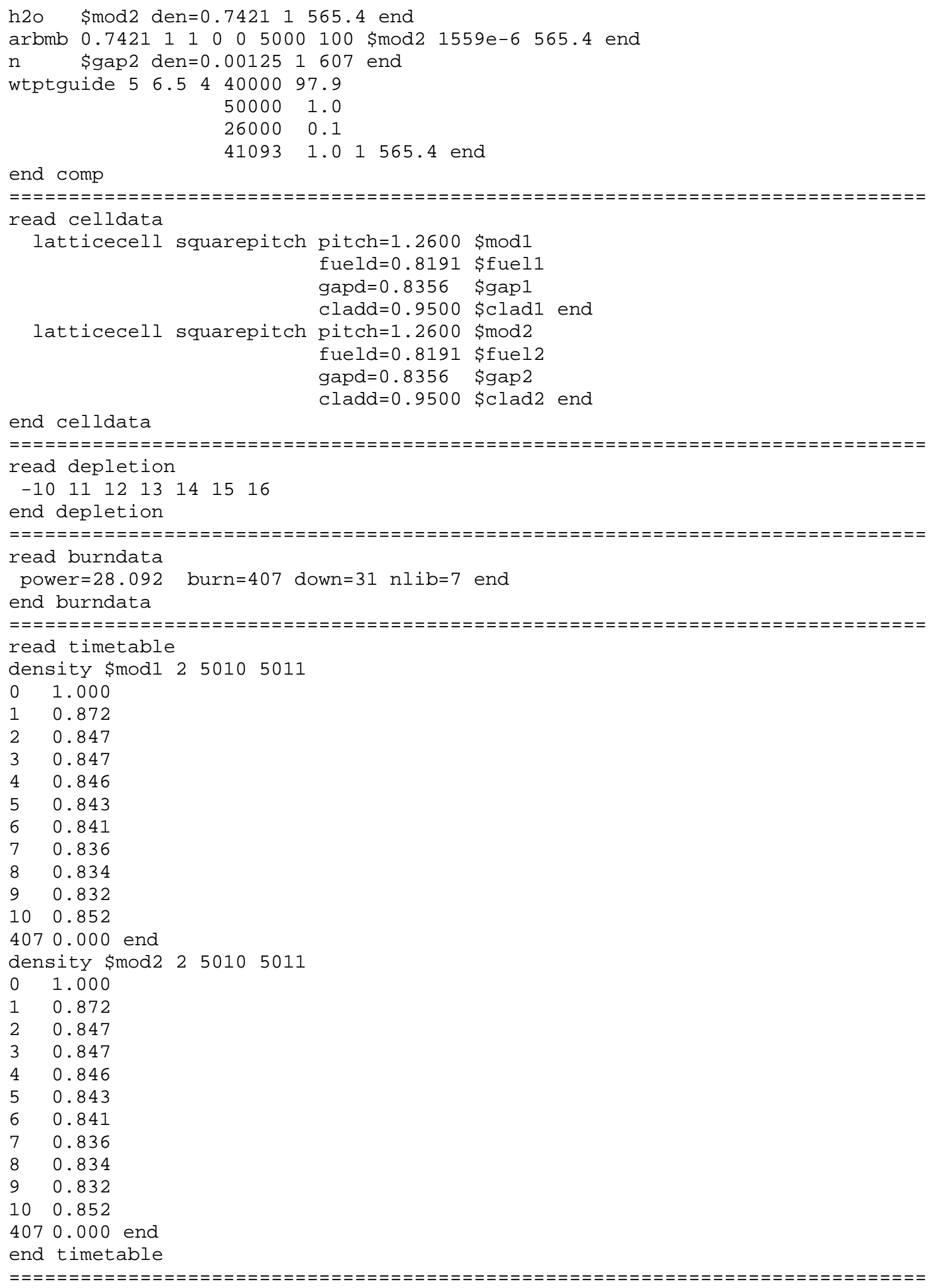




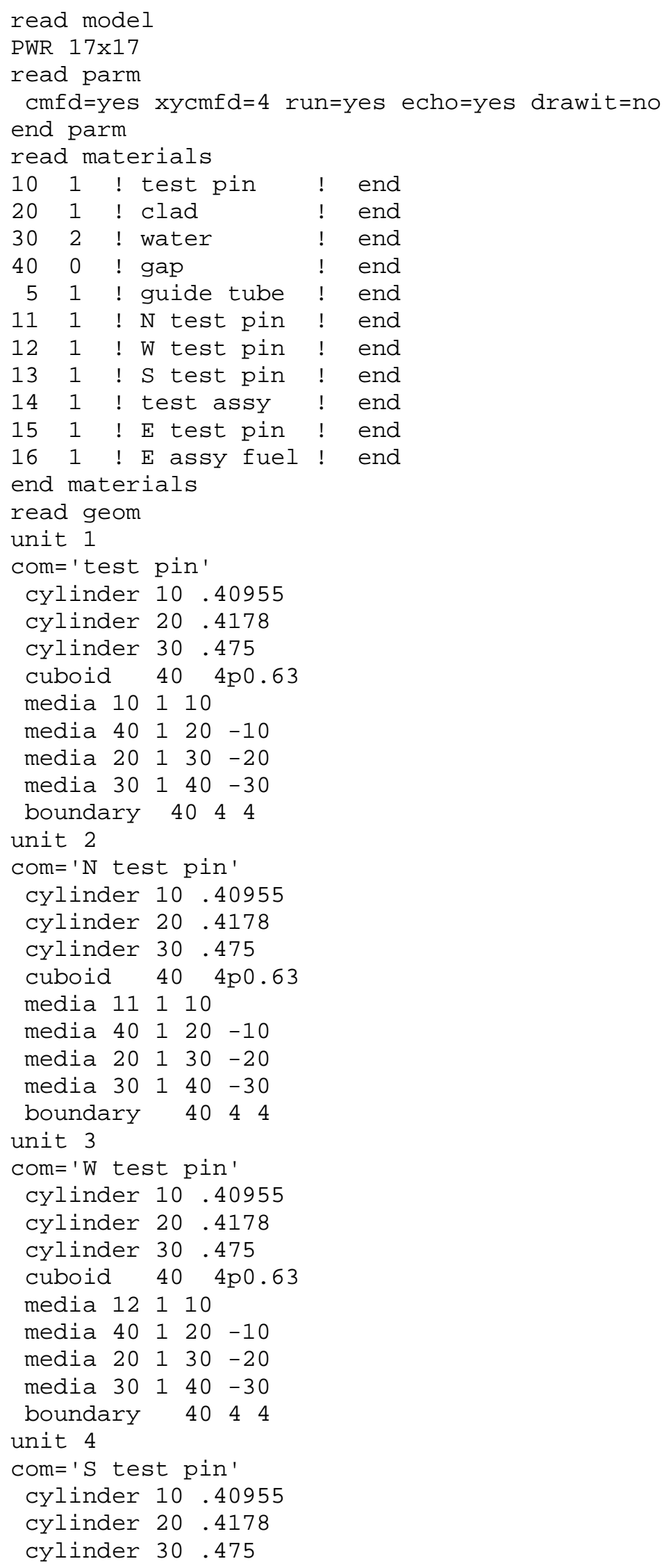




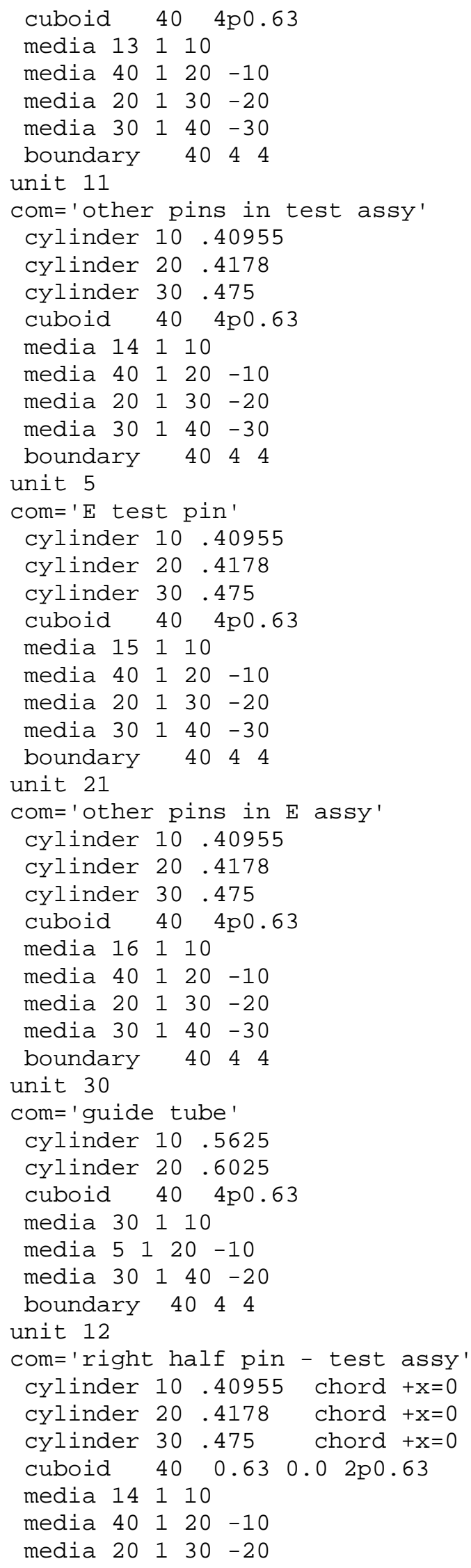




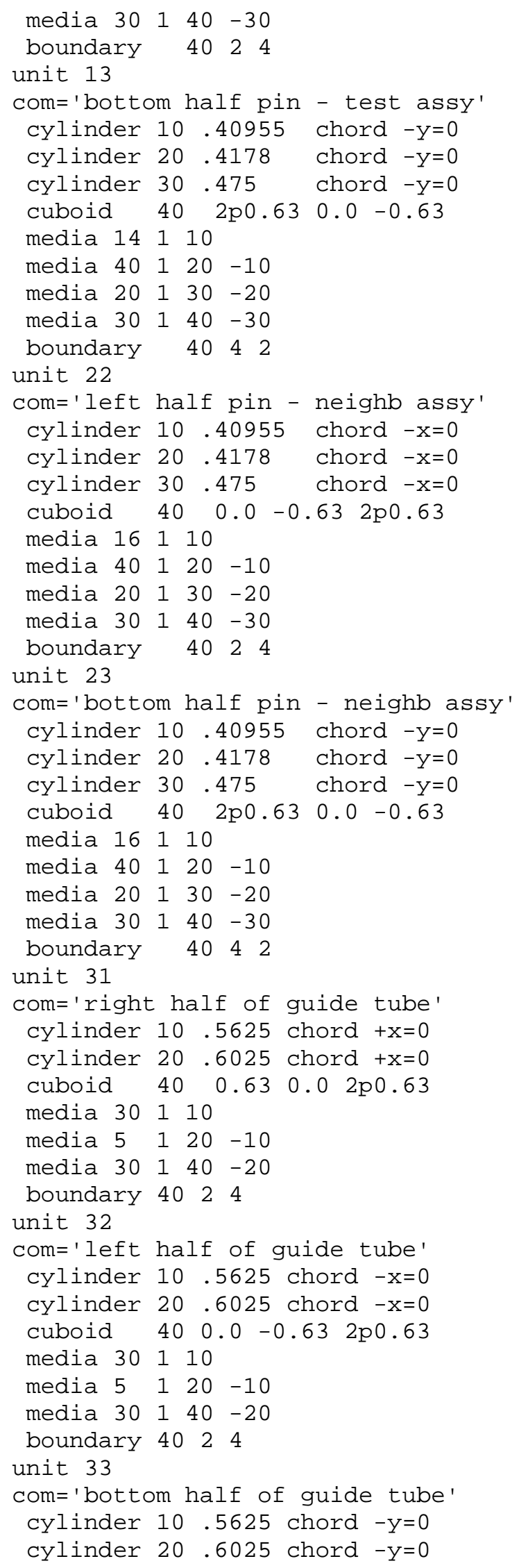




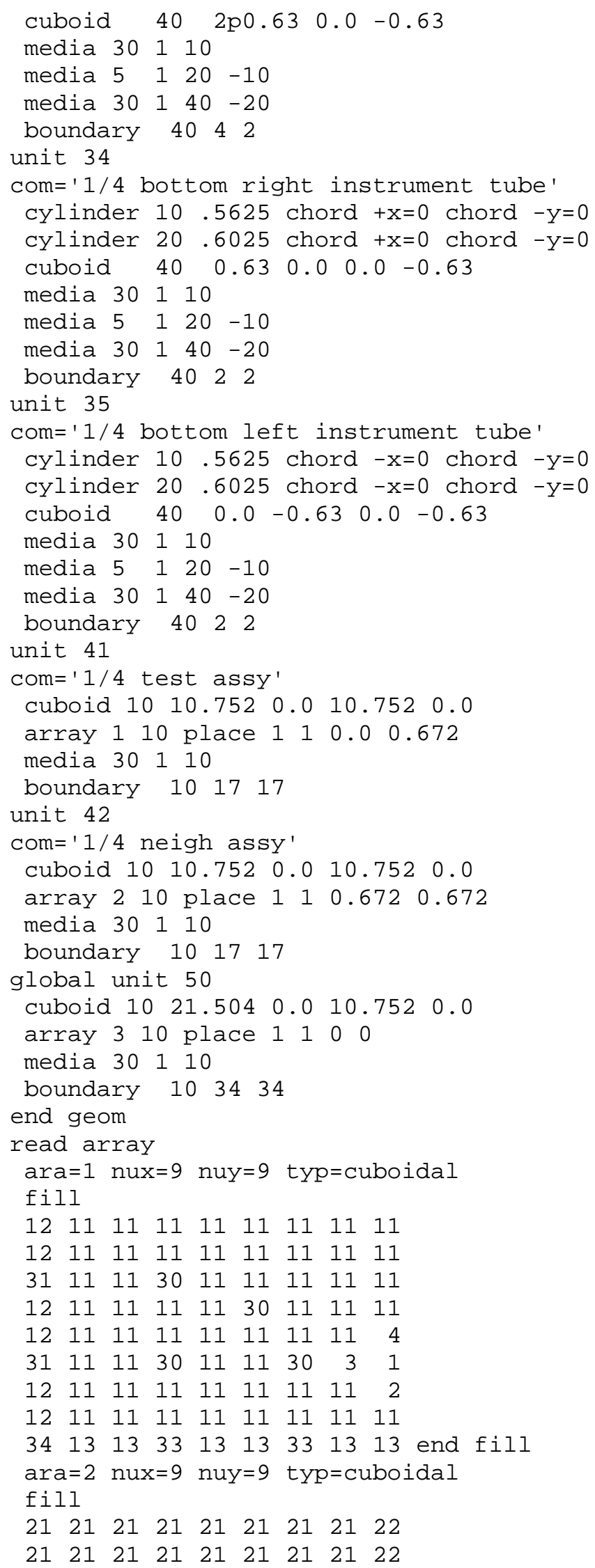




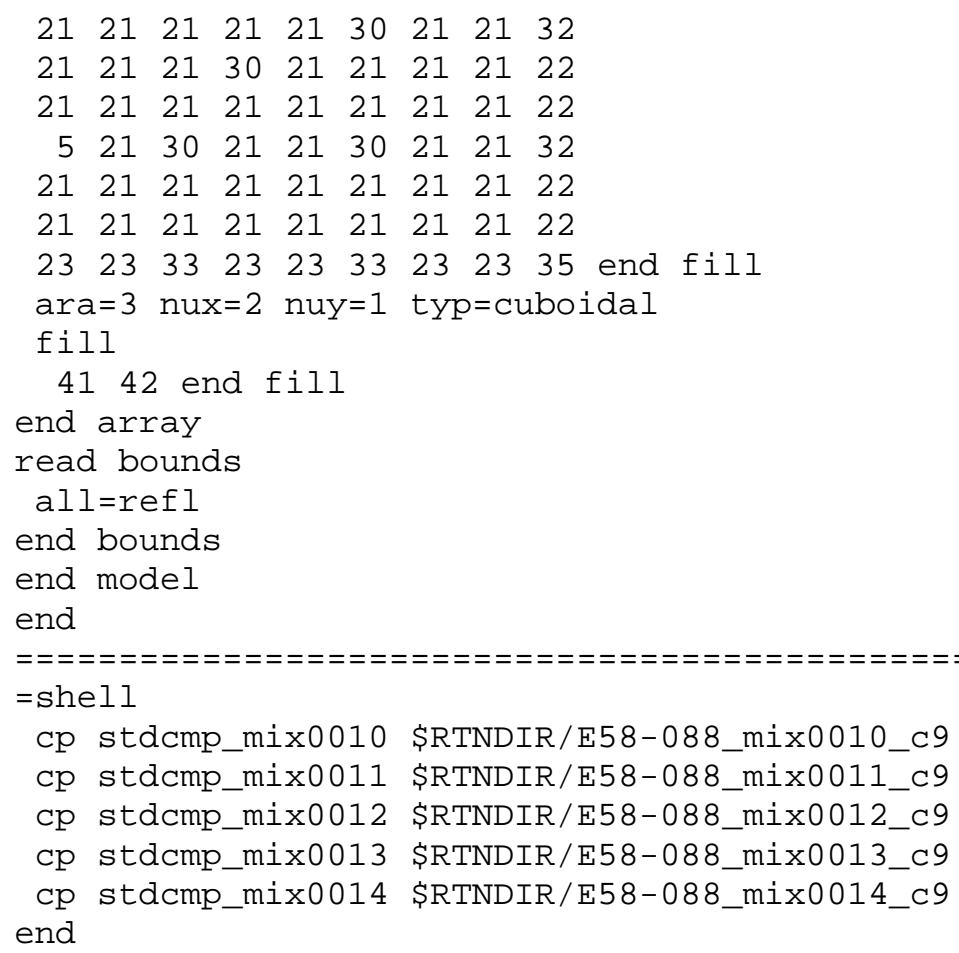




\section{A.4 TRITON INPUT FILE FOR SAMPLE E58-88, CYCLE 10}

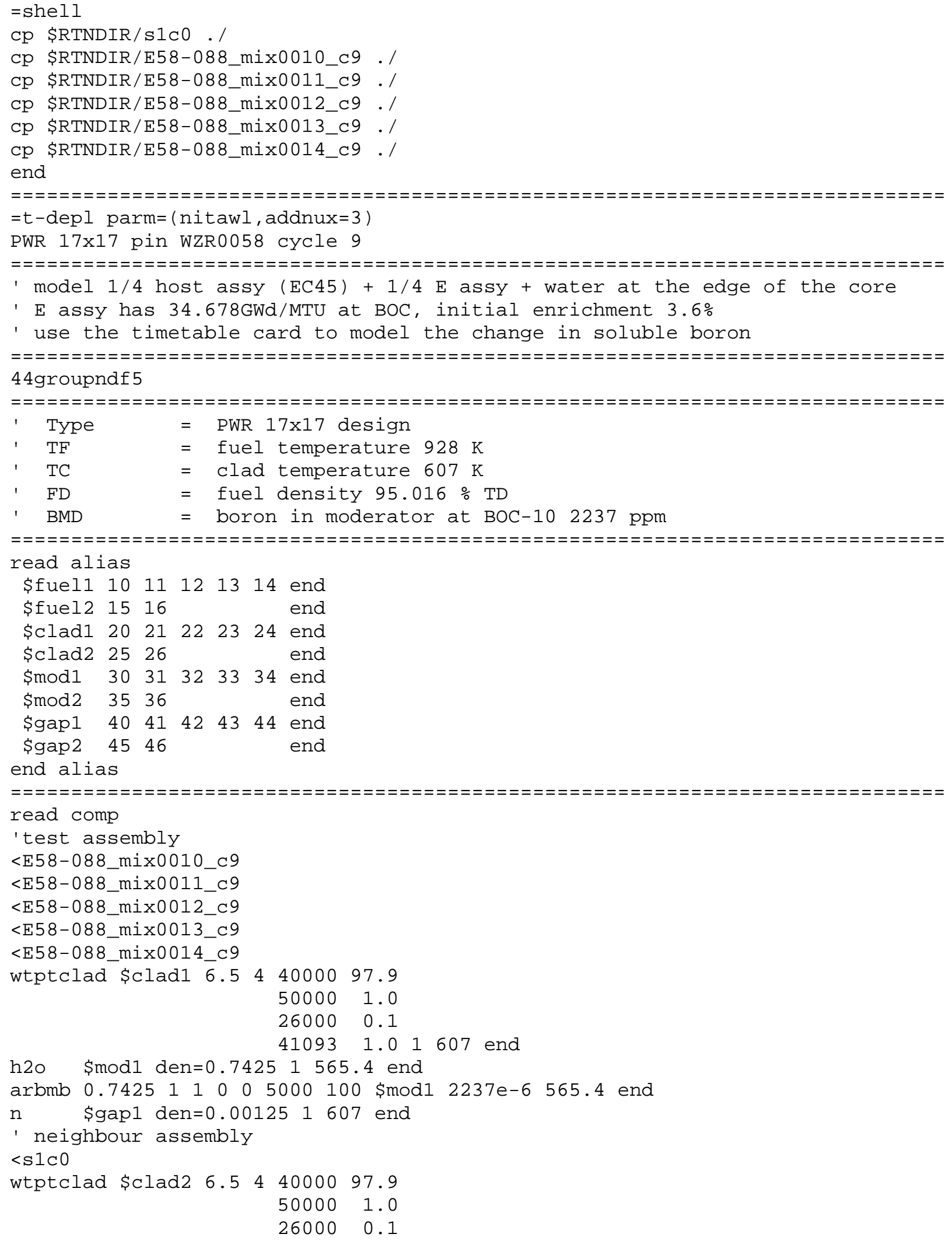




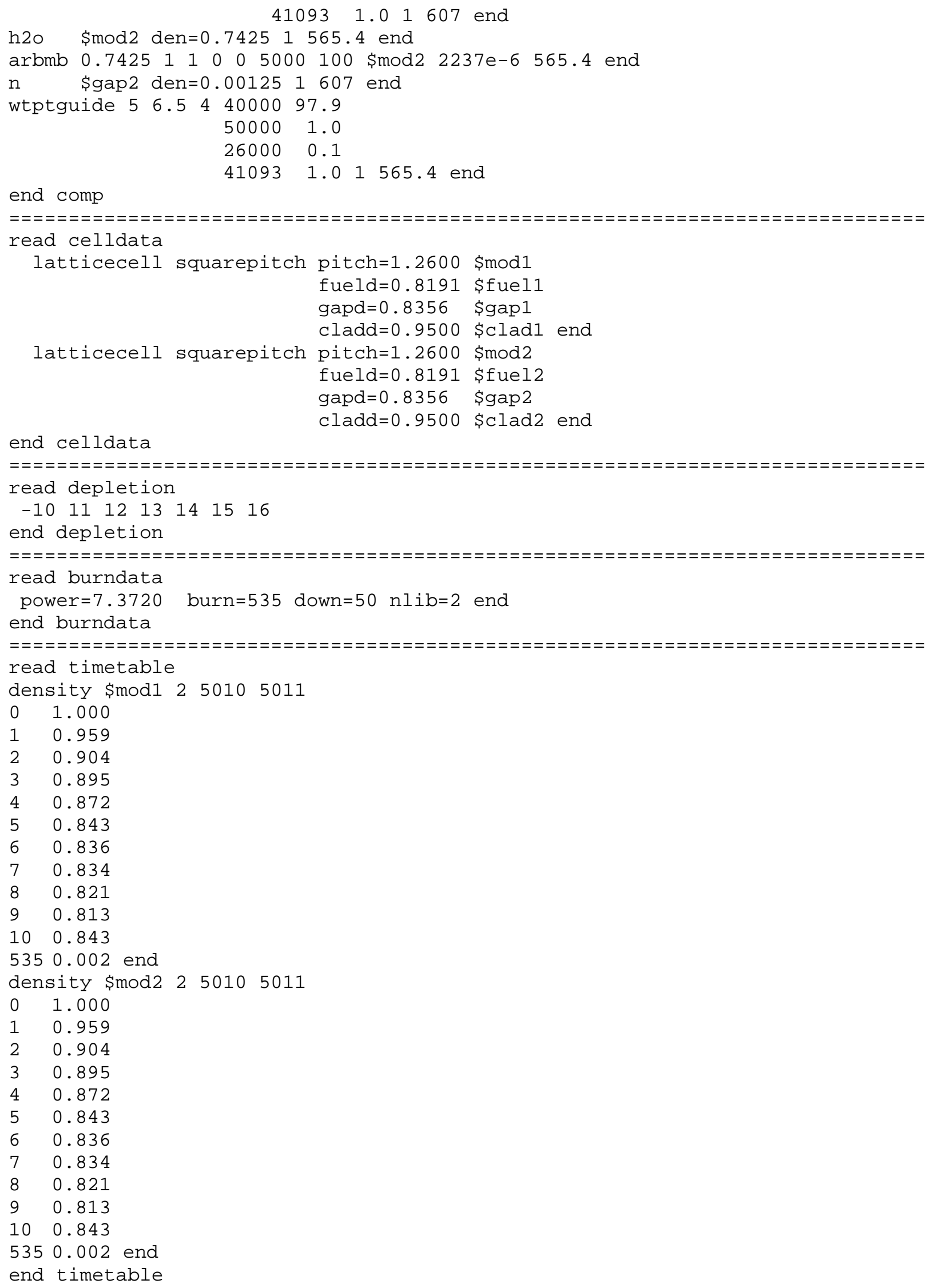




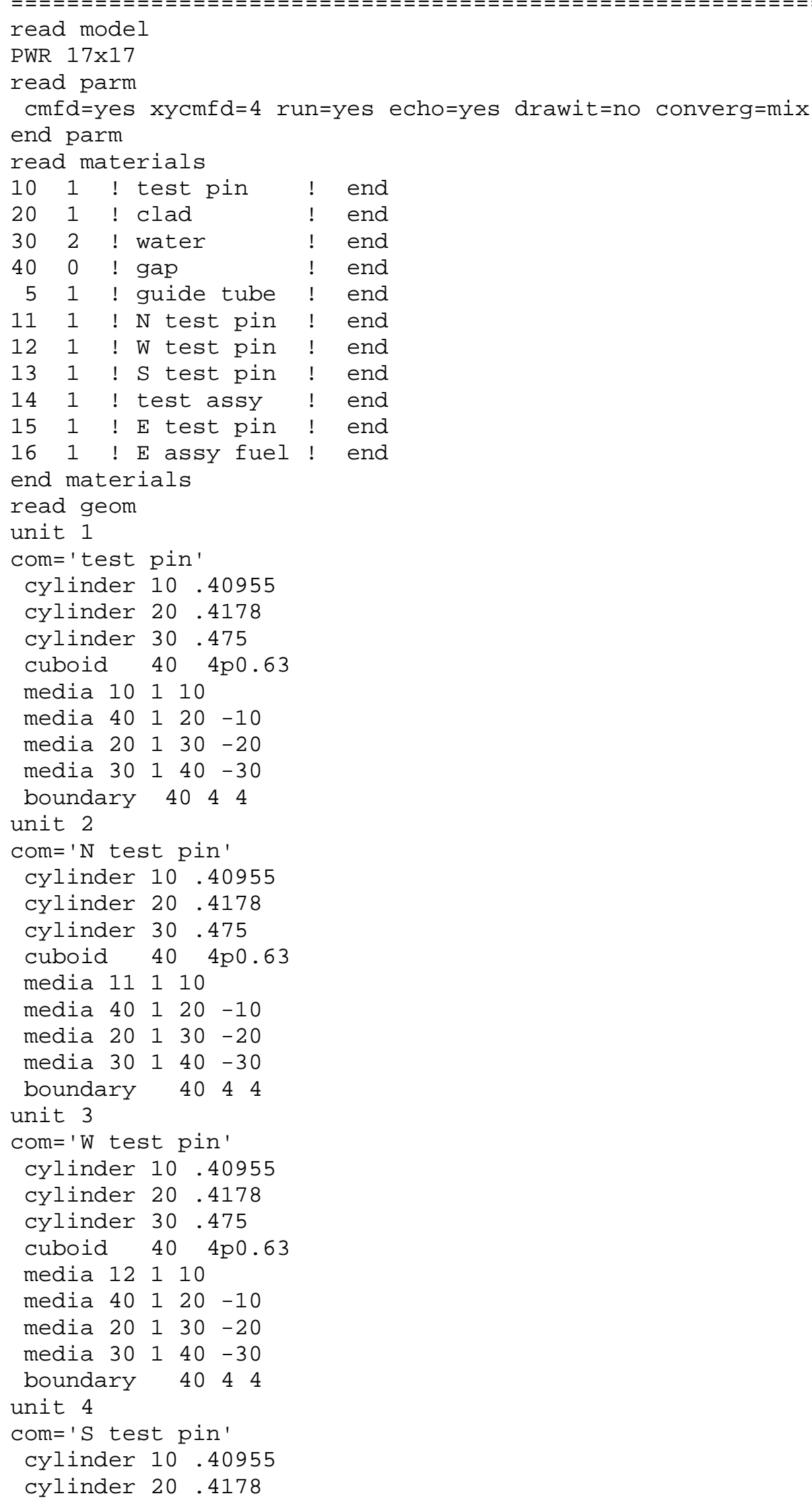




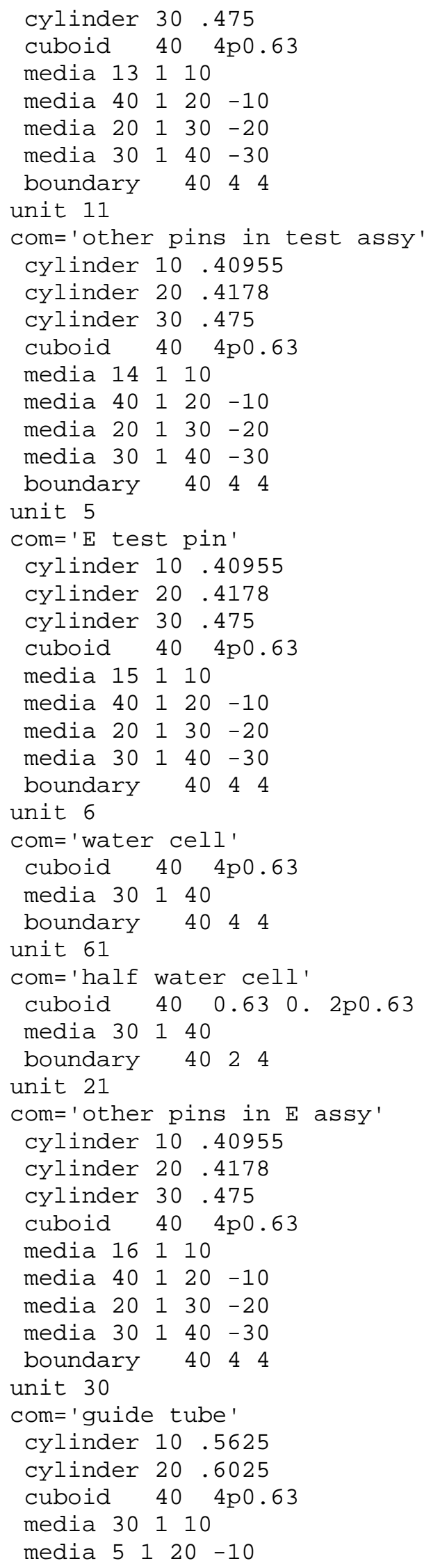




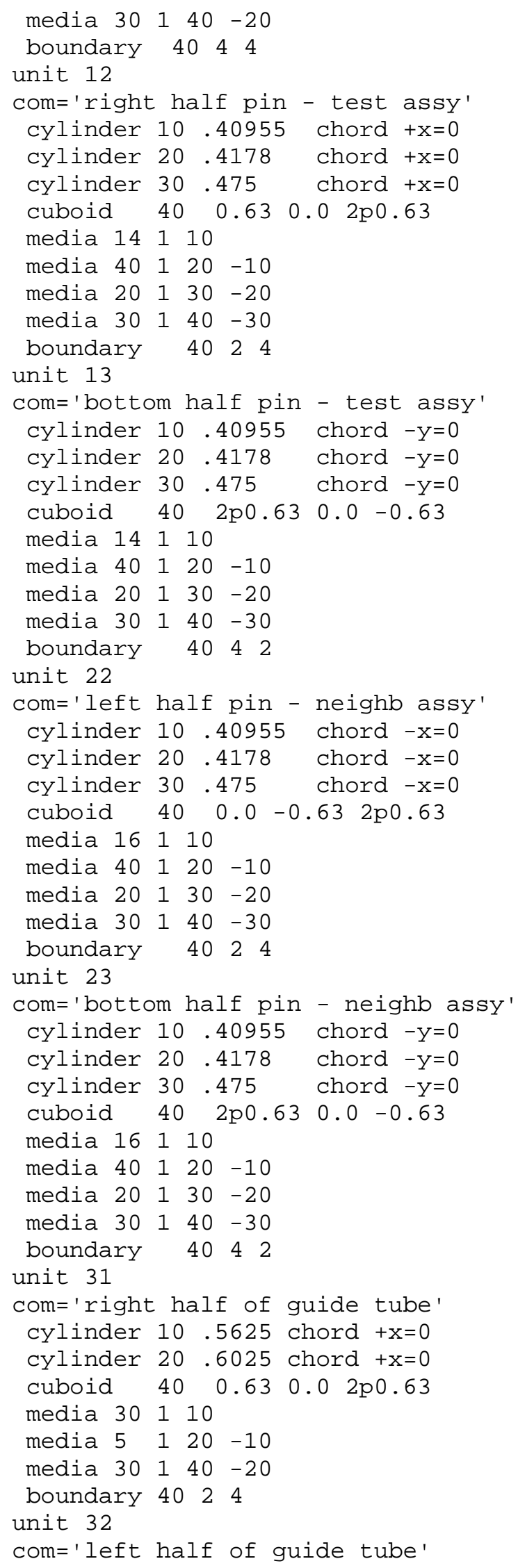




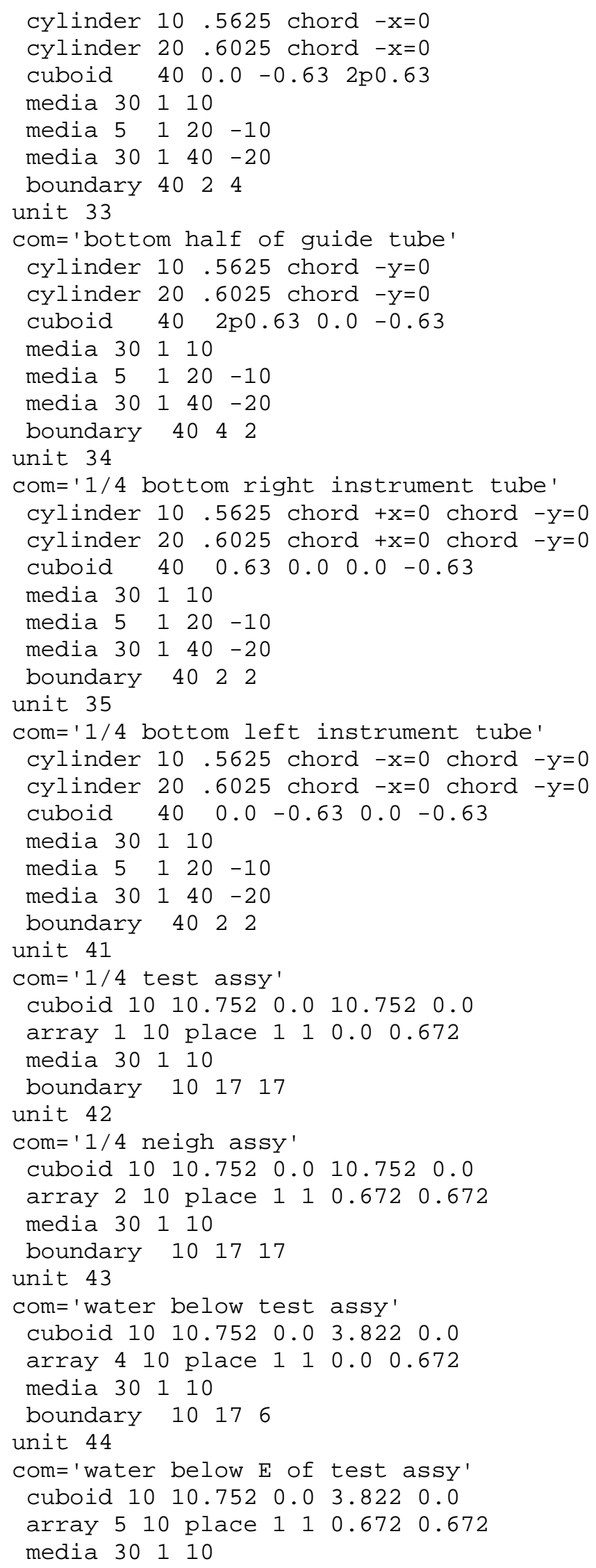




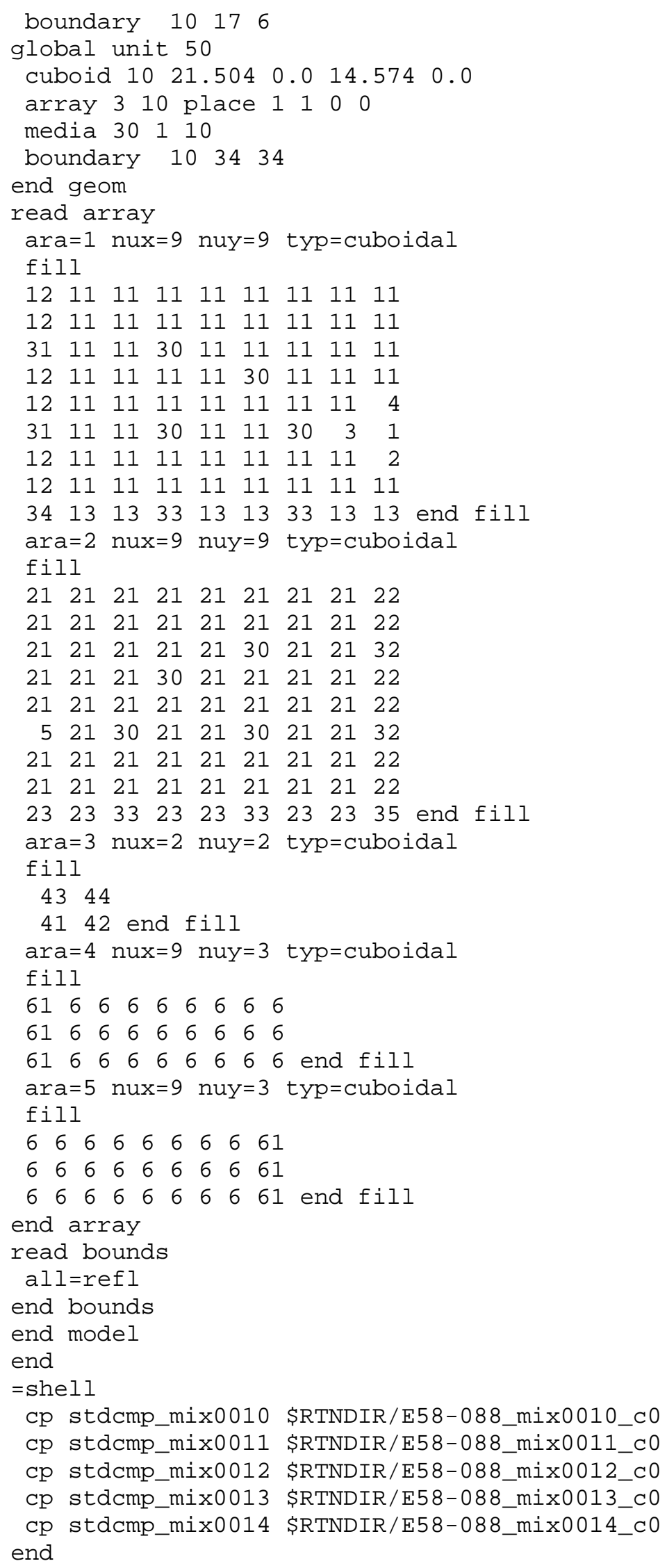




\section{A.5 TRITON INPUT FILE FOR SAMPLE E58-88, CYCLE 11}

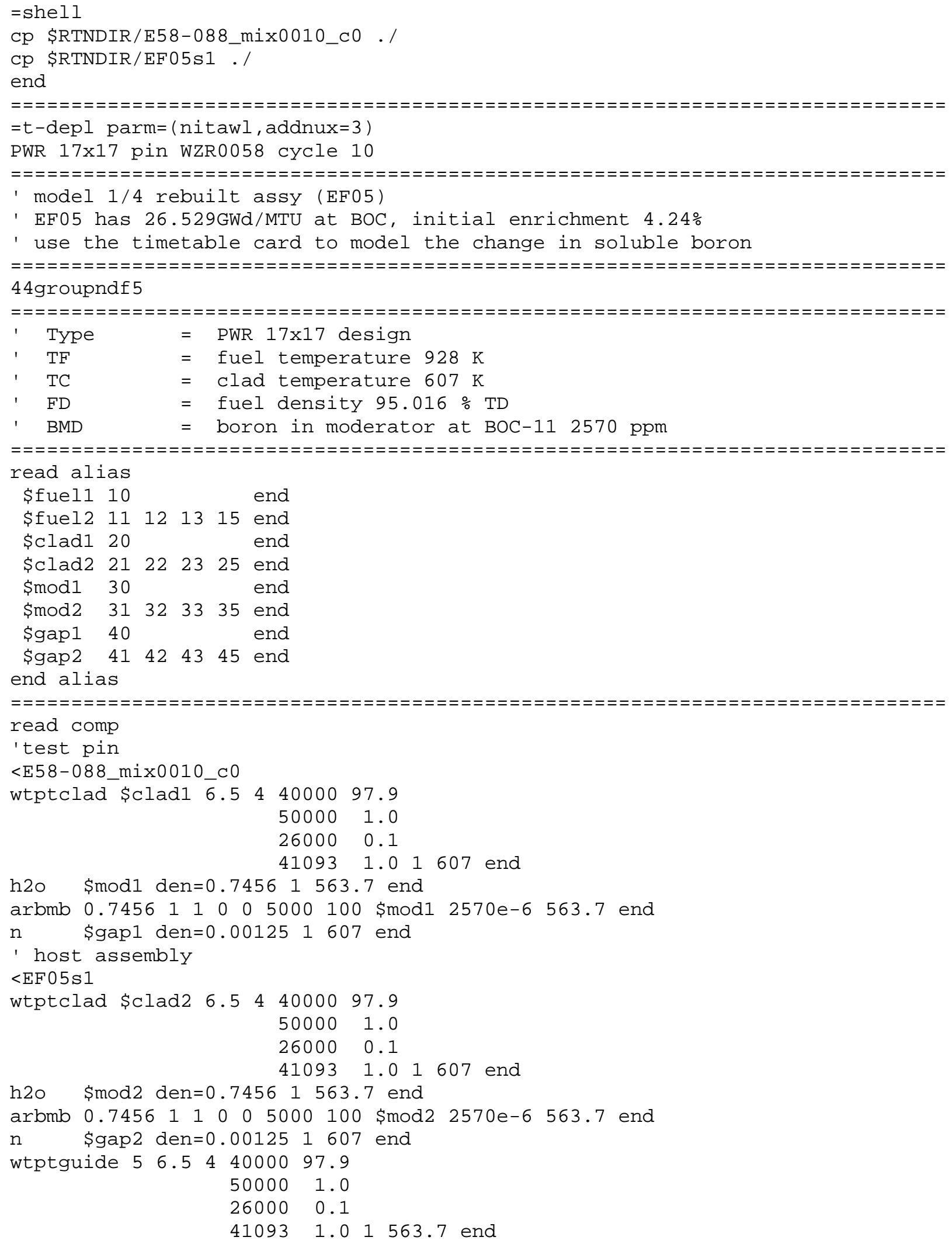




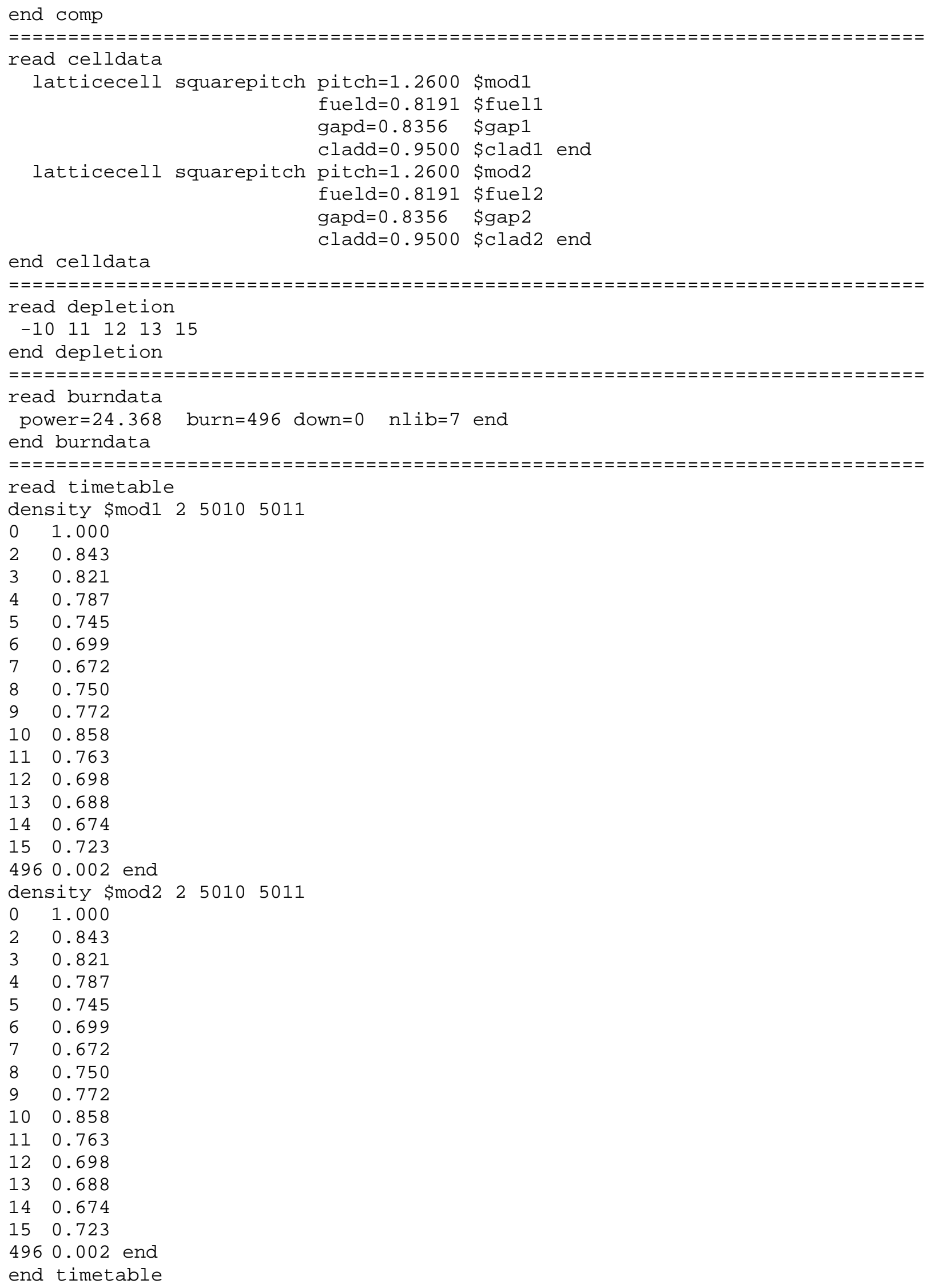




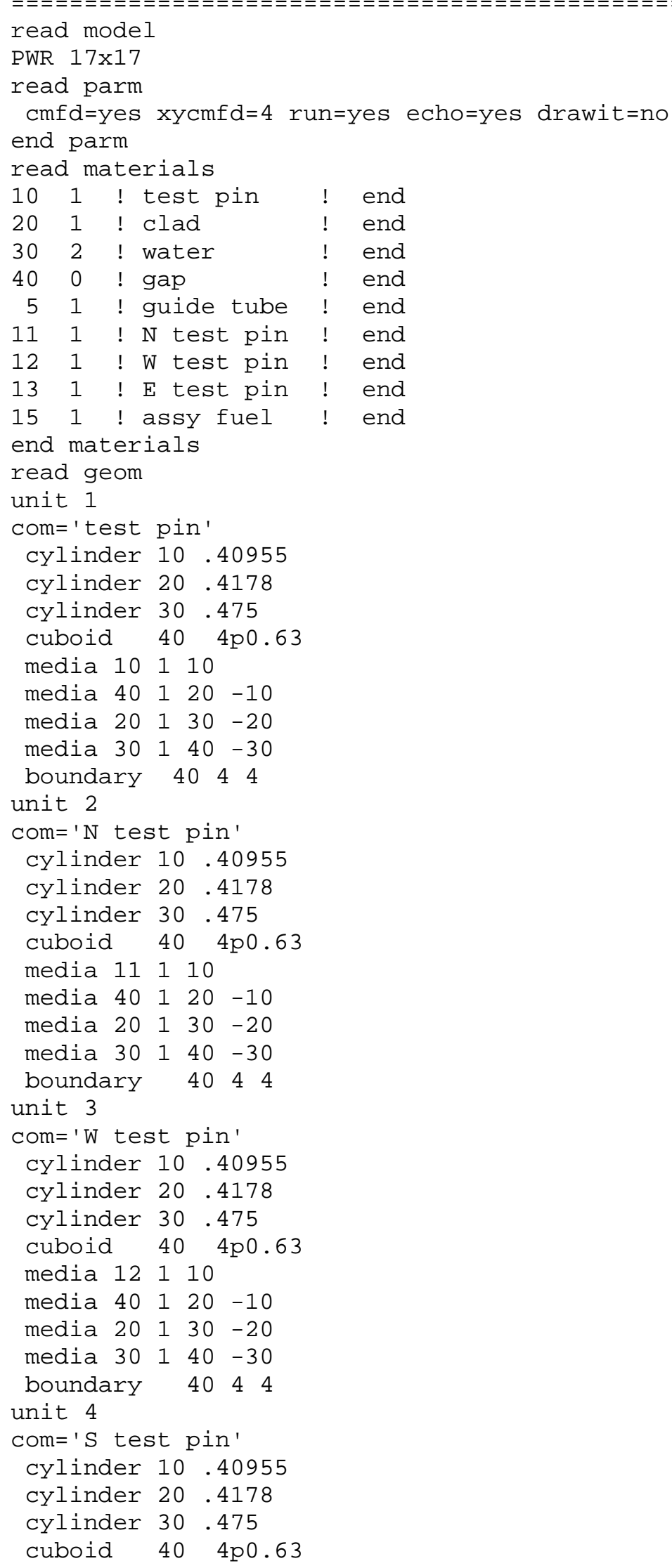




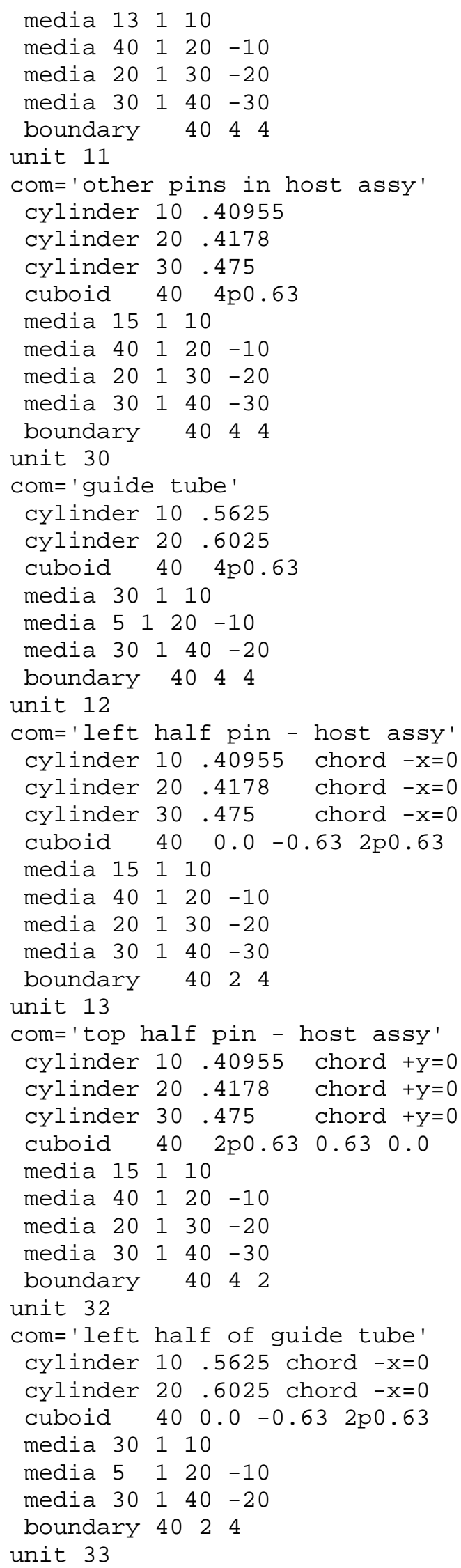




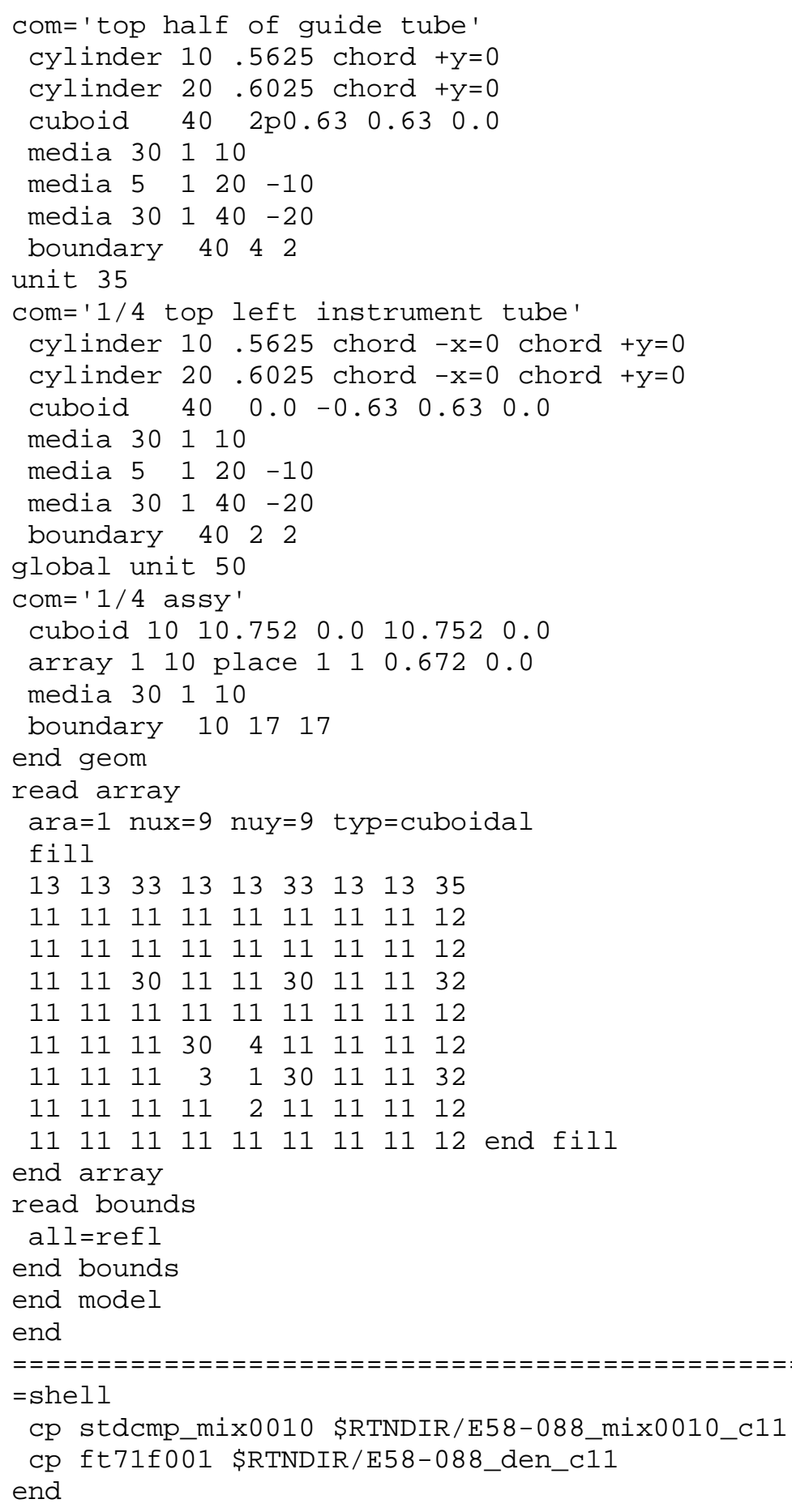




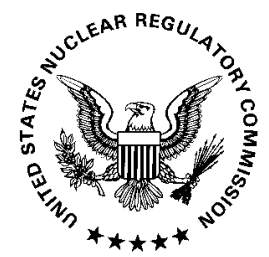

NUREG/CR-7013

ORNL/TM-2009/321 